\title{
Experimentos de microarrays e teoria da resposta ao item
}

\author{
Carlos Eduardo Neves
}

\author{
DISSERTAÇÃO APRESENTADA \\ $\mathrm{AO}$ \\ INSTITUTO DE MATEMÁTICA E ESTATÍSTICA \\ DA \\ UNIVERSIDADE DE SÃO PAULO \\ PARA \\ OBTENÇÃO DO TÍTULO \\ DE \\ MESTRE EM ESTATÍSTICA
}

Programa: Estatística

Orientadora: Profa. Dra. Júlia Maria Pavan Soler

São Paulo, Fevereiro de 2010 


\section{Experimentos de microarrays e teoria da resposta ao item}

Este exemplar corresponde à redação final da dissertação devidamente corrigida e defendida por Carlos Eduardo Neves e aprovada pela Comissão Julgadora.

Banca Examinadora:

- Prof. Dra. Júlia Maria Pavan Soler (orientadora) - IME-USP.

- Prof. Dr. Dalton Francisco de Andrade - INE-CTC/UFSC.

-Prof. Dr. Luis Aparecido Milan - DEs - UFSC. 


\section{Agradecimentos}

\section{Ao meu super pai,}

Obrigado por me apoiar durante todos estes anos de vida. Você sempre esteve presente nos momentos fáceis e difíceis que já deparei em minha vida, contemplando não somente o seu papel de pai, mas, também, o de um grande amigo. Espero estar te retribuindo, sem nenhuma obrigação, mas por puro prazer, tudo de bom que você já me proporcionou. Se eu pudesse desejar algo nesta vida, desejaria ser metade da pessoa que você é, pois me daria por satisfeito e muito feliz. Agora está na hora de trabalhar e dar um pouco de folga ao super pai!

\section{Ao meu inigualável irmão,}

Suas palavras sempre foram bem vindas e de muito valor para minha formação como pessoa. Neste momento preciso por para fora de meu coração todo agradecimento pelo fabuloso incentivo que você me deu durante o mestrado, o qual me ajudou no processo de conquista de mais esta etapa da vida. Se hoje estou prestes a obter um título de mestre pela Universidade de São Paulo, pode ter certeza de que este feito não seria possível sem o seu suor, dedicação, inteligência, suporte e carinho. Você faz parte desta conquista! Se fosse possível colocar o seu nome nas entrelinhas do meu diploma, eu seria a primeira pessoa a escrevê-lo com firmeza, clareza e muito orgulho, mas saiba que em meu coração seu nome já está gravado nele há muito tempo. Obrigado por tudo. Obrigado por ser este irmão tão querido e inigualável.

\section{À minha extraordinária companheira,}

São poucas as palavras que conheço e insuficiente o espaço que este documento me possibilita utilizar para descrever sua importância nesta conquista. Começamos nosso relacionamento no início do mestrado e desde o 
primeiro dia você esteve a par de todas as dificuldades que enfrentei durante esta etapa, sempre me apoiando e ajudando de diversas formas. Com toda segurança posso afirmar que você fez a diferença para que eu obtivesse o sucesso e não o fracasso na conquista do título de mestre. Durante todo o percurso desta conquista, aquelas centenas de ligações telefônicas que você realizou foram fundamentais para me transmitir a energia necessária para continuar estudando e trabalhando para chegar até o final desta etapa. Quero te dizer mais uma vez que você é a minha extraordinária companheira. Obrigado pelo suporte.

\section{Aos meus familiares,}

Agradeço a todos por estarem sempre próximos a minha pessoa, fazerem parte da minha vida e me incentivarem durante o mestrado. Um agradecimento especial para a minha querida avó Leonilda Angelini Neves.

\section{Às pessoas fisicamente ausentes,}

Dizem que toda vida tem um propósito. A minha é amar todas as pessoas que mereçam ser amadas e mantê-las sempre presentes no meu coração. Vocês me ajudaram a trilhar todo o caminho para chegar onde hoje estou. A conquista de mais uma etapa é fruto do que vocês plantaram um dia. Muito obrigado. Em especial, dedico esta dissertação a mulher que mais me deu amor nesta vida... minha querida mãe.

\section{À minha orientadora,}

Dentre as escolhas assertivas de importância que já realizei na minha vida posso citar a "escolha" de minha orientadora de mestrado. Inicialmente, preciso agradecê-la por ter me aceitado como seu orientando e, principalmente, por ter executado seu papel com excelência. Seu respeito para comigo e sua dedicação estarão sempre presentes em minha memória. Preciso muito agradecer e enfatizar sua paciência e compreensão frente àqueles momentos em que 
necessitei me dedicar a outras atividades de minha vida. Fico muito contente e honrado por ela ter compartilhado comigo o seu precioso tempo, sua inteligência e, também, por ter direcionado as atividades desenvolvidas durante o mestrado, enfatizando minhas obrigações sempre que se fez necessário. Não há nada mais prazeroso e motivador para um aluno do que se deparar com a sua orientadora e vê-la sempre de bom humor e motivada para recebê-lo e ensiná-lo. Hoje posso dizer que tenho em quem me espelhar profissionalmente. Espero que ao término desta etapa surjam outras oportunidades para trabalharmos em conjunto. Obrigado por fazer parte desta conquista.

\section{Aos amigos e colegas de classe,}

A conquista nunca é mérito de uma única pessoa. Mais importante do que um título é ter feito boas amizades e ter convivido com grandes pessoas. Agradeço a todos os meus amigos e colegas de mestrado que estiveram ao meu lado no decorrer desta conquista. Em particular, agradecimentos a: Agnes Simidu, Filipe Zabala, João Celeste Jr. e Renato Gava.

\section{Aos amigos do CRUSP,}

Agradeço muito a ajuda e colaboração dos meus grandes amigos Artemir Coelho e Cléber Figueiredo.

\section{Aos colaboradores do InCor-USP}

Agradeço aos pesquisadores do InCor-USP a oportunidade ímpar que me foi concedida: conhecer e trabalhar em parceria com uma equipe amplamente qualificada. Agradeço também a disponibilização do banco de dados de Microarrays, o qual ajudou a enriquecer este trabalho. 


\section{Resumo}

Recentemente desenvolvida, a biotecnologia denominada por Microarrays permite o monitoramento simultâneo dos valores de expressão gênica de centenas de milhares de genes, fator este que traz uma nova interpretação aos resultados obtidos em pesquisas desenvolvidas nas mais diversas áreas do conhecimento incluindo, por exemplo, a Farmacologia e Medicina, uma vez que os resultados obtidos são interpretados ao nível molecular. Contudo, apesar de muita tecnologia ser empregada à técnica de Microarrays, sua aplicação ainda ocasiona algumas complicações decorrentes, por exemplo, das inúmeras fontes de variação existentes, da escala das respostas ou da natural dificuldade de se analisar uma grande quantidade de fragmentos genéticos avaliados sob poucas unidades experimentais. Frente a estas complicações, atualmente, muitas são as propostas metodológicas de análises estatísticas para atenuar ou eliminar os problemas inerentes à técnica de Microarrays e propiciar a extração de resultados mais confiáveis a partir dos valores de expressão gênica, porém muitos desafios ainda persistem. Sob esta colocação, o presente trabalho procurou explorar duas metodologias de análise estatística alternativas no que diz respeito a seus conceitos, embora ambas tenham sido contextualizadas ao problema de Microarrays e aplicadas para se atingir o mesmo objetivo: possibilitar a identificação dos genes diferencialmente expressos sob distintas condições experimentais. A primeira metodologia consistiu da aplicação de Modelos de Análise de Variância de efeitos fixos com a adoção de modificações nas estatísticas de teste, metodologias de correções para múltiplos testes e a construção de gráficos vulcão. Já, a segunda metodologia consistiu da contextualização e aplicação da Teoria da Resposta ao Item - TRI aos experimentos de Microarrays, abordagem esta pouco explorada na análise deste tipo de dado, mas a qual possibilita a seleção de genes diferencialmente expressos a partir de uma medida latente estimada para cada gene e a construção de uma escala para as categorias de resposta de expressão gênica.

A motivação para este trabalho originou de um experimento de Microarrays com ratos congênicos disponibilizado pelo Laboratório de Cardiologia e Genética Molecular do Instituto do Coração (InCor-USP) cujo objetivo é identificar "genes" associados à hipertensão. 
Palavras-chave: Microarrays, Teoria da Resposta ao Item, Oligonucleotídeos, Ratos congênicos, MAANOVA, genes diferencialmente expressos. 


\section{Abstract}

Recently developed, the biotechnology denominated Microarrays permits a simultaneous monitoring of the gene expression values of hundred thousands of genes; fact that introduces a new interpretation of the results obtained in researches developed in many distinct areas including, for example, Pharmacology and Medicine, once the obtained results are read according to the molecular level. However, despite the fact that much technology is used in the Microarrays technique, its application still causes some implications, for example, the countless sources of existing variance, the scale of answers or the natural difficulty in analyzing a large number of genetic fragments measured by few experimental units. Facing such complications, a lot of methodologies were suggested in order to reduce or eliminate the problems caused by the Microarrays technique and also foster the obtainment of more reliable results from the gene expression values, yet many challenges still persist. Under this perspective, the present work aimed at exploring two alternative methodologies regarding concepts, despite both were contextualized according to the Microarrays problem and applied with the same objective: enabling the identification of the genes differently expressed under different experimental conditions. The first methodology was composed by the application of Analysis of Variance Models of fixed effects with changes in the test statistics, correction methodologies for multiple tests and volcano plot. The second methodology consisted of the contextualization and application of the Item Response Theory - IRT towards the Microarrays experiments, being this one not much explored in analysis that use this kind of data, but enabling the selection of genes differently expressed from an estimated latent trait for each gene and the construction of a scale for the categories of gene expression answers.

The motivation for the present work came from an experiment of Microarrays with congenic mice made available by the Cardiology and Molecular Genetics Laboratory of the Heart Institute (InCor-USP) that aimed at identifying "genes" associated with hypertension.

Key words: Microarrays, Item Response Theory, Oligonucleotide, congenic mice, MAANOVA, differentially expressed genes. 


\section{Sumário}

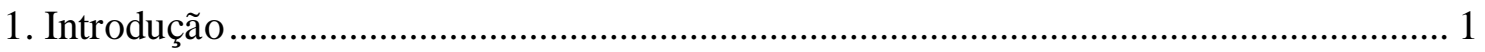

1.1. Considerações preliminares................................................................................ 1

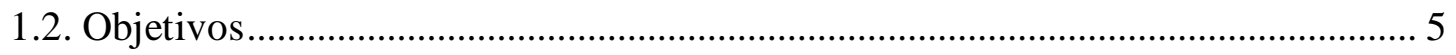

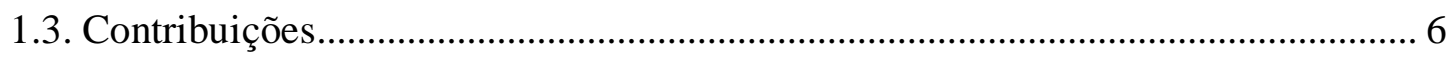

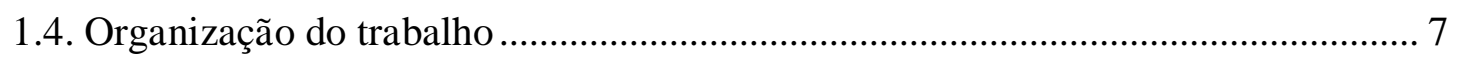

2. Experimentos com Microarrays ……………………………………………….... 9

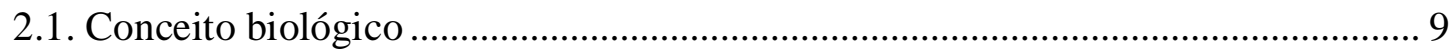

2.2. A técnica de Microarrays e a sua importância ...................................................... 11

2.3. Problemas técnicos inerentes aos experimentos de Microarrays ……………….... 17

2.4. Desafios estatísticos e biológicos presentes nos experimentos de Microarrays.. 18

2.5. Métodos de correção e normalização...................................................................... 24

2.5.1. Correção pelo Background ……………………………………………...... 24

2.5.2. Métodos de normalização ……………………………………………………. 27

3. Metodologias de análise estatística para experimentos de Microarrays ....................... 33

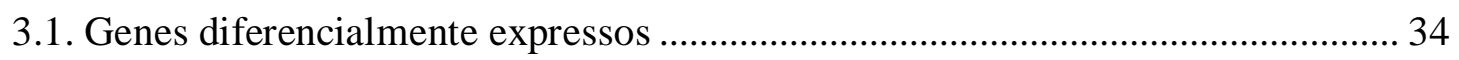

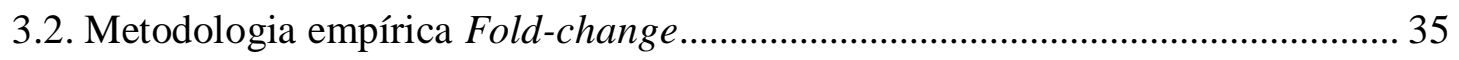

3.3. Teste $t$ e testes $t$ modificados................................................................................ 36

3.4. Mais do que duas condições experimentais........................................................... 45

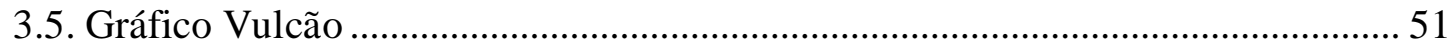

4. Teoria da Resposta ao Item - TRI ……………………………………………….... 53

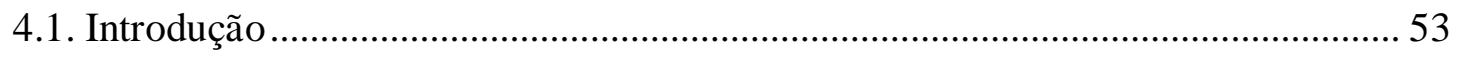

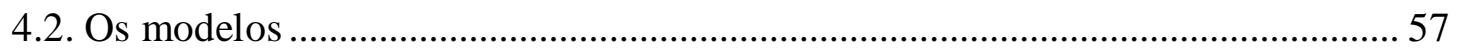

4.2.1. Curva Característica do Item - CCI ……………………………………..... 58

4.2.2. Modelos para itens avaliados de forma dicotômica ou dicotomizados .......... 60

4.2.3. Modelos para itens avaliados de forma politômica ............................................. 66

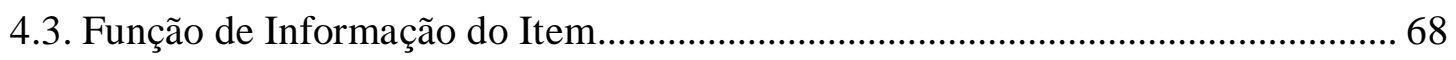

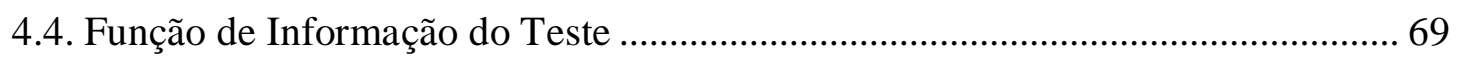

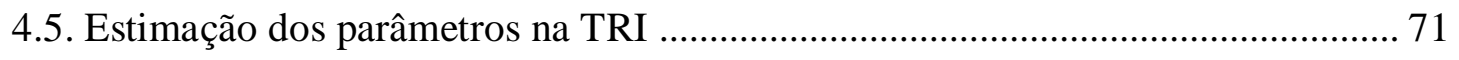

4.6. Contextualização da TRI em experimentos de Microarray …………………….... 74 


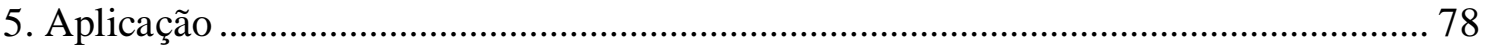

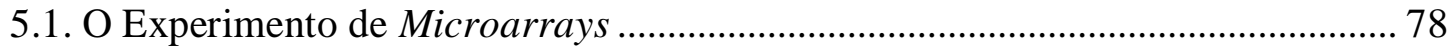

5.2. Modelos de ANOVA para Microarrays - MAANOVA …...................................... 85

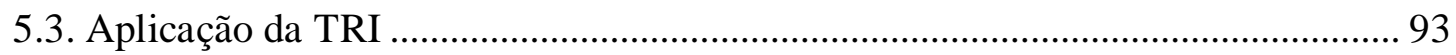

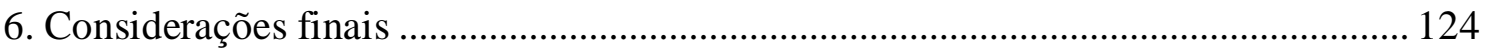

A. Distribuição dos valores de expressão gênica - animais congênicos ......................... 126

B. CCI - animais congênicos - Modelo Samejima........................................................ 128

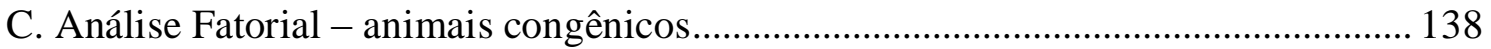

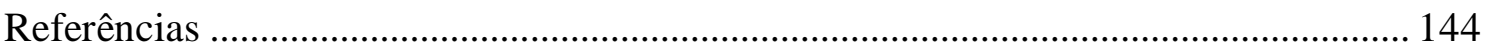




\section{Capítulo 1}

\section{Introdução}

De modo a fornecer ao leitor uma visualização mais clara sobre o enfoque deste trabalho e uma descrição direcionada aos principais pontos técnicos da metodologia de Microarrays, se optou por ausentar desta introdução especificações muito técnicas, as quais serão minuciosamente apresentadas nos capítulos seguintes.

\subsection{Considerações preliminares}

Há muito tempo em Bioestatística se tem buscado soluções para diversos problemas da Biologia. Em particular, grandes esforços têm sido empregados nos estudos relacionados às mais diversas doenças que afetam direta ou indiretamente a população humana. Em grande parte destes estudos como, por exemplo, aqueles relacionados à hipertensão, obesidade, diabetes ou à depressão, na tentativa de se encontrar ou compreender os prováveis fatores que levam ou estejam relacionados à ocorrência das mesmas, pesquisadores têm feito uso de inúmeras informações dos pacientes que incluem, por exemplo, características pessoais gerais (idade, sexo, hábito alimentar, hábito de ingestão de bebidas alcoólicas, hábito de fumar, etc.), características hereditárias (altura, peso, raça, etc.) e características baseadas no histórico familiar (número de pessoas com a mesma doença na família, etc.) (Norman, 2008; Vittinghoff et al., 2007). Contudo, com o caminhar das pesquisas biológicas ao longo dos anos e, principalmente, com o avanço da biotecnologia, além dessas informações, na tentativa de aprimorar os resultados das pesquisas e fornecer uma nova visão às interpretações dos mesmos, uma rica fonte de informação baseada na amostragem de características do genoma dos pacientes tem sido atualmente usada em estudos biológicos e muito explorada através da Bioestatística (Brown \& Botstein, 1999).

Atualmente, estudos genômicos têm sido aplicados por pesquisadores de diversas áreas do conhecimento como, por exemplo, a Medicina, a Farmacologia, a 
Agronomia e a Zootecnia. Em muitos casos, o principal interesse está no entendimento do funcionamento simultâneo dos genes e suas relações com determinadas características de um organismo. As primeiras tentativas de se estudar as relações entre as características de um organismo e seus genes eram baseadas em realizações experimentais contendo um único ou poucos genes, pois não havia biotecnologia suficiente que permitisse o monitoramento simultâneo de uma grande quantidade de genes. Todavia, hoje, a realidade dos experimentos genéticos é bem diferente, dado que os avanços biotecnológicos permitiram a construção de técnicas laboratoriais como, por exemplo, a técnica de Microarrays, capazes de monitorar centenas de milhares de genes simultaneamente (Woo et al., 2004).

O monitoramento dos genes utilizando a tecnologia de Microarrays é realizado por meio da mensuração de seus valores de expressão gênica. Como será visto em detalhes neste trabalho, o valor de expressão gênica está relacionado à quantidade de mRNA encontrada na célula sob certa condição experimental. Desta forma, a mensuração dos valores de expressão gênica é fundamental para se investigar diferenças entre organismos de mesma espécie ou mesmo entre órgãos de um mesmo organismo.

Embora possa parecer abstrato mensurar valores de expressão gênica, por não se ter uma dimensão física associada à mesma tão transparente como, por exemplo, as dimensões associadas à altura (em metros) ou ao peso (em $\mathrm{kg}$ ) de um paciente, a técnica de Microarrays proporciona a mensuração destes valores a partir de um artefato engenhoso. Nos experimentos de Microarrays, o processo de quantificação dos valores de expressão gênica pode ser dividido, didaticamente, nos seguintes estágios: extração das amostras (por exemplo, diferentes tecidos ou células), identificação (coloração) das amostras, hibridização das amostras e leitura dos valores de expressão gênica. Em linhas gerais, após a extração dos materiais a serem analisados, cada amostra é devidamente identificada através de um processo químico que agrega às mesmas uma particular coloração. Em seguida, as amostras identificadas são despejadas sobre os arrays (lâminas, em geral de vidro), onde estão presentes os spots (cavidades físicas geometricamente espaçadas) nos quais estão fixados os "genes" de interesse no estudo. No estágio de hibridização das amostras, após a ocorrência de princípios biológicos, é esperado que o material despejado no array se interligue aos "genes". Esta interligação é interpretada como a quantidade de mRNA que está transcrevendo o gene na amostra sob investigação, sendo assim, uma representação indireta da expressão gênica. Como 
as colorações incorporadas às amostras são preservadas no estágio de hibridização, quanto maior a interligação entre um particular "gene" e o material presente na amostra, maior a intensidade de cor presente no spot onde este "gene" está fixado. Por fim, a intensidade de coloração presente em cada spot do array é mensurada com o auxílio de um scanner de alta resolução (artefato engenhoso), se atribuindo a este valor contínuo de intensidade de luz/coloração a nomenclatura "expressão gênica".

No entanto, apesar da avançada biotecnologia empregada nestes experimentos, os valores de expressão gênica mensurados, ainda assim, sofrem influências de inúmeras fontes de variação indesejáveis incorporadas durante a execução dos estágios anteriormente descritos, gerando algumas dificuldades na análise dos dados e tornando necessária a aplicação de metodologias estatísticas específicas para validar as conclusões experimentais (Churchill, 2002). Para lidar com as dificuldades derivadas dos efeitos indesejáveis, distintas metodologias de análise estatística para correção dos valores de expressão estão propostas na literatura, estando a escolha das mesmas diretamente relacionada às fontes de variação indesejáveis que se deseja atenuar ou remover. Por exemplo, Bolstad (2004), McGee \& Chen (2006), Ritchie et al. (2007), Silver \& Smith (2009) sugerem metodologias de correção para as variações provocadas pelo denominado efeito de background (um tipo de "borrão" que margeia os limites de um spot). Por outro lado, para atenuar ou eliminar as variações provenientes, por exemplo, de materiais laboratoriais com diferente qualidade ou com desgastes ao longo das utilizações, autores como, por exemplo, Yang et al. (2002), Smyth et al. (2003), Smyth \& Speed (2003), Baird et al. (2004), Bolstad (2004), Chou et al. (2005), Do \& Choi (2006), Dabney \& Storey (2007), Calza et al. (2008), Xiong et al. (2008), propõem as metodologias denominadas por normalização. As aplicações das metodologias para correção dos valores de expressão gênica são essenciais para se extrair conclusões mais seguras dos dados e deve ser o primeiro passo a ser realizado em qualquer análise de expressão gênica (Hill, 2001).

Além dos efeitos indesejados agregados aos valores de expressão gênica durante a execução da técnica de Microarrays, outras dificuldades encontradas ao se trabalhar com esta técnica podem ser citadas. Por exemplo, há uma dificuldade natural em se trabalhar com os valores contínuos de expressão gênica devido ao pouco entendimento que se tem da grandeza e escala desta variável. Além disso, em muitos casos, a distribuição dos valores de expressão gênica possui forma assimétrica com coeficiente 
de curtose positivo bastante elevado, fato que, freqüentemente, induz à aplicação da função logarítmica base 2 aos valores "originais" de expressão gênica na tentativa de se obter um comportamento mais tratável da distribuição da variável (Speed, 2000). Neste tipo de experimento também pode ser apontada a dificuldade relacionada ao problema de dimensionalidade, ou seja, a necessidade de se analisar uma grande quantidade de genes avaliados sob poucas unidades amostrais (muito comum em Microarrays devido aos altos custos experimentais), resultando no denominado problema "small $n$ large $p$ " $(n \ll p)$ discutido por West (2003). Em paralelo a esta última dificuldade mencionada, emerge, também, o problema de múltiplos testes estatísticos, o qual necessariamente deve ser tratado para evitar ou controlar a ocorrência dos resultados falso-positivos (classificar um gene como diferencialmente expresso quando este não o é). Neste trabalho algumas metodologias denominadas por controle FWER (Family-Wise Error Rate) e FDR (False Discovery Rate) (Benjamini \& Hochberg, 1995), para controlar a ocorrência dos resultados falso-positivos, serão exploradas. Embora existam dificuldades agregadas à técnica de Microarrays, do ponto de vista estatístico, estas podem ser interpretadas como grandes desafios analíticos (Li \& Hong, 2001).

Frente às dificuldades em se trabalhar com os valores contínuos de expressão gênica, caso não se opte por trabalhar com metodologias de correção para os valores de expressão gênica ou adotar distribuições que se ajustem aos dados, que nem sempre são triviais, uma abordagem metodológica alternativa para eliminar, por exemplo, possíveis diferenças de grandeza entre os valores de expressão gênica, consiste em se optar pela categorização dos valores de expressão gênica, ou seja, conduzir as análises a partir do rank (ordenação e classificação) das observações. Além disso, vale considerar que pelo fato do valor de expressão gênica ser mensurado de forma indireta, esta medida pode ser encarada como uma informação latente (Li \& Hong, 2001). Seguindo estas duas colocações, dentre as metodologias alternativas de análise de dados categorizados contemplando informações latentes se encontra a Teoria da Resposta ao Item - TRI, a qual foi explorada e aplicada neste trabalho no contexto de Microarrays. Em linhas gerais, a TRI engloba os modelos matemáticos que descrevem a probabilidade de um indivíduo (uma pessoa, um gene, etc.) fornecer resposta a uma determinada categoria de um item (uma questão de uma prova, um tipo de animal, etc.) em função das características do item (discutidas mais adiante neste trabalho) e, também, em função da informação latente (conhecimento do aluno, predisposição do gene em se expressar, 
etc.) pertinente ao indivíduo (Andrade et al., 2000; Baker \& Kim, 2001). Unindo a possibilidade de se trabalhar com os valores de expressão gênica categorizados e de se construir uma estrutura latente, uma interessante abordagem apresentada por Li \& Hong (2001) faz a contextualização da TRI aos experimentos de Microarrays na tentativa de procurar padrões de expressão gênica diferencial.

Apesar da TRI não ter sido amplamente explorada no contexto de Microarrays, dadas as potencialidades desta metodologia de análise que incluem, por exemplo: a não necessidade de se aplicar inúmeras técnicas estatísticas para correção dos valores de expressão gênica que antecedem as análises que, de fato, interessam aos pesquisadores; a flexibilidade de adaptação dos modelos contidos nesta teoria a diversas situações; a possibilidade de se identificar genes diferencialmente expressos daqueles não expressos a partir de uma medida latente (o que parece plausível se tratando de Microarrays), este trabalho vem a explorar tanto as análises usuais para Microarrays quanto a TRI, esta última em busca de resultados diferenciados (seja na maior precisão em se classificar genes como diferencialmente expressos - DE ou na interpretação final dos resultados).

\subsection{Objetivos}

Neste trabalho se teve por objetivo revisar as metodologias de análise estatística aplicadas à experimentos realizados com a técnica de Microarrays. Em especial, maior ênfase é dada para as propostas metodológicas que consideram o tipo de delineamento experimental adotado, correções nas estatísticas de teste e, principalmente, na proposta de contextualização da TRI como uma "nova" ferramenta para determinação de genes diferencialmente expressos em análise de dados de Microarrays.

Em particular, este trabalho contou com a colaboração do instituto do Coração (InCor), o qual forneceu uma base de dados proveniente de um experimento de Microarrays (descrito em detalhes no capítulo Aplicação) desenvolvido com o propósito de se explorar a relação entre os valores de expressão gênica associados à hipertensão e a diferentes perturbações no sistema biológico de um grupo de ratos expostos ou não à sobrecarga salina. Desta forma, um objetivo direto deste trabalho consistiu em analisar os dados fornecido pelo InCor à procura de genes diferencialmente 
expressos a partir da aplicação de modelos de ANOVA de efeitos fixos e da TRI. Com relação à metodologia ANOVA, se teve por objetivo aplicar um modelo condizente com o delineamento experimental adotado pelos pesquisadores, este que corresponde a um delineamento fatorial $5 \times 2$ aleatorizado com estrutura de blocos completos, onde um dos fatores representa a linhagem do animal ("mudança na estrutura biológica" (5 níveis)) e o outro fator a situação "controle" e "sal" ("exposição à sobrecarga salina" (2 níveis)). Cada um dos 10 grupos contou com 5 animais, sendo que as leituras dos valores de expressão gênica nos arrays foram realizadas, por restrições físicas do experimento, para conjuntos de 10 arrays por vez (um de cada grupo), estrutura esta que definiu os blocos. Na ANOVA se utilizou as estatísticas $F$ modificadas apresentadas por Cui \& Churchill (2003) e por Cui et al. (2005), além de metodologias de correções para múltiplos testes como, por exemplo, o controle FWER e FDR (Benjamini \& Hochberg, 1995). Por outro lado, ao se aplicar a TRI a Microarrays se teve por objetivo avaliar a TRI como uma ferramenta poderosa na análise de dados de Microarrays e que introduz diversas vantagens. Para isso, o presente estudo procurou contextualizar o problema sob dois modelos pertencentes à TRI e aplicá-los com o mesmo objetivo da ANOVA, encontrar aqueles genes diferencialmente expressos sob as distintas condições experimentais consideradas.

A seguir são apresentadas as possíveis contribuições deste trabalho e a forma com a qual o mesmo foi organizado.

\subsection{Contribuições}

Acredita-se que como principal contribuição este trabalho explora mais uma abordagem de análise estatística para dados de experimentos de Microarrays por meio da contextualização e aplicação da TRI a este "cenário", sendo que esta abordagem proporciona a utilização de modelos probabilísticos bem definidos para auxiliar a classificação de genes como diferencialmente expressos ou não, os quais, de certo modo, reduzem a complexidade dos dados (se torna desnecessária a aplicação de inúmeras técnicas para correção das medidas de expressão gênica) e oferecem certo grau de simplificação para o processo de análise. Além disso, uma vez que os dados analisados fazem parte de um projeto de pesquisa em andamento no InCor, se espera 
que a disponibilização dos resultados obtidos neste trabalho possa acrescentar informações que auxiliem futuros estudos. Em adição, uma vez que os modelos de ANOVA utilizados neste trabalho são usualmente aplicados a Microarrays, estes se tornam uma ferramenta de referência para validação dos resultados encontrados sob a TRI, pois, do ponto de vista biológico, se espera que genes classificados como DE por meio da ANOVA, também recebam as mesmas classificações por meio da TRI, ou seja, o fato de um gene estar DE expresso ou não, não depende da metodologia estatística utilizada, mas sim das características biológicas em questão.

\subsection{Organização do trabalho}

No Capítulo 2, são apresentados os principais conceitos da biologia molecular necessários para se compreender a técnica de Microarrays, a descrição detalhada de como são realizados os experimentos de Microarrays e a importância destes nos estudos genômicos. Dando continuidade, duas das principais técnicas (plataformas) de Microarrays são introduzidas, sendo, também, expostos os problemas comuns inerentes a estas técnicas. Por fim, são caracterizados os desafios estatísticos e biológicos presentes nestes estudos.

O Capítulo 3 traz as metodologias de análises estatísticas mais utilizadas em experimentos de Microarrays para determinação de genes diferencialmente expressos para comparações realizadas entre duas ou mais condições experimentais, incluindo as estatísticas de testes modificadas e o gráfico vulcão. Ainda neste capítulo, indispensavelmente, também é introduzido o problema de múltiplos testes, naturalmente presentes nos experimentos de Microarrays, e as metodologias para controle dos denominados resultados falso-positivos.

No Capítulo 4 a TRI é introduzida. Em particular, os "pontos-chave" desta teoria e os principais modelos para dados de natureza dicotômica ou dicotomizados e dados de natureza politômica ou politomizados são apresentados. Em seguida, as ferramentas utilizadas na TRI para interpretação dos resultados e realização de diagnósticos são introduzidas, bem como são descritas as diferentes metodologias de estimação dos parâmetros dos modelos da TRI e apresentado um breve histórico sobre o processo de 
evolução dessas metodologias até os dias atuais. Ao término deste capítulo é realizada a contextualização da TRI aos experimentos de Microarrays como proposta de análise estatística para detecção de genes diferencialmente expressos.

O Capítulo 5 é marcado pela descrição detalhada do experimento de Microarrays realizado pelo laboratório de Cardiologia Molecular do InCor sob o qual se fez a aplicação prática das metodologias anteriormente descritas, sendo expostas as propostas de análise estatística adotadas e os resultados obtidos.

Concluindo o trabalho, no Capítulo 6, são apresentadas as discussões sobre os resultados, as considerações finais sobre as metodologias adotadas e, por fim, são expostas colocações para futuros projetos e/ou estudos. 


\section{Capítulo 2}

\section{Experimentos com Microarrays}

\subsection{Conceito biológico}

Nesta seção são introduzidos alguns conceitos básicos sobre biologia molecular, os quais serão suficientes para fornecer a base de raciocínio necessária para compreensão da metodologia de Microarrays. Contudo, para mais detalhes dos conceitos aqui apresentados, o leitor pode consultar Alberts et al. (2002), Lewin (2009), Junqueira e Carneiro (2005) ou Zaha (2003).

No núcleo das células de um organismo está presente a molécula de DNA (Deoxyribonucleic Acid), a qual contém toda a informação genética de um organismo. A molécula de DNA é formada por cerca de 3 bilhões de bases nitrogenadas ${ }^{1}$ complementares (ver Figura 1), em formato de dupla hélice. Cada conjunto de três bases nitrogenadas caracteriza um aminoácido $^{2}$ e o seqüenciamento de aminoácidos caracteriza uma proteína, molécula responsável por controlar a estrutura e a função celular.

Os genes, transmitidos de uma geração a outra, são partes funcionais do DNA responsáveis por carregarem as informações que possibilitarão a criação de uma ou mais proteínas distintas, após o desencadeamento seqüencial de atividades intracelulares e extracelulares. O dogma central da biologia molecular (ver Figura 2), descrito em 1958 por Francis Crick na tentativa de relacionar o DNA, o RNA e as proteínas, ilustra os processos intracelulares e extracelulares responsáveis desde a duplicação do DNA até a codificação de novas proteínas.

\footnotetext{
${ }^{1}$ Composto cíclico contendo nitrogênio.

${ }^{2}$ Unidade de uma proteína.
} 


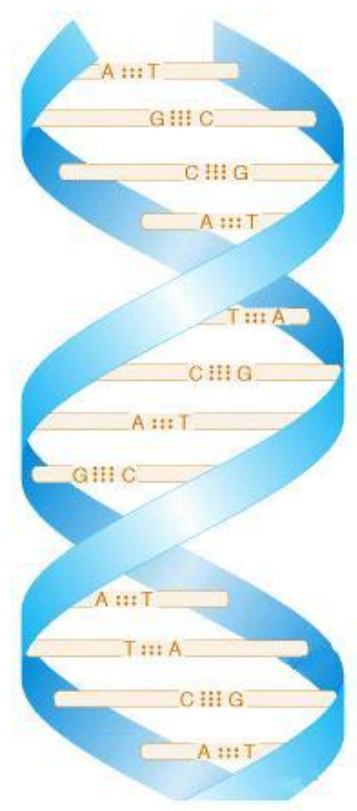

Figura 1. Seqüência de bases nitrogenadas complementares (dupla hélice).

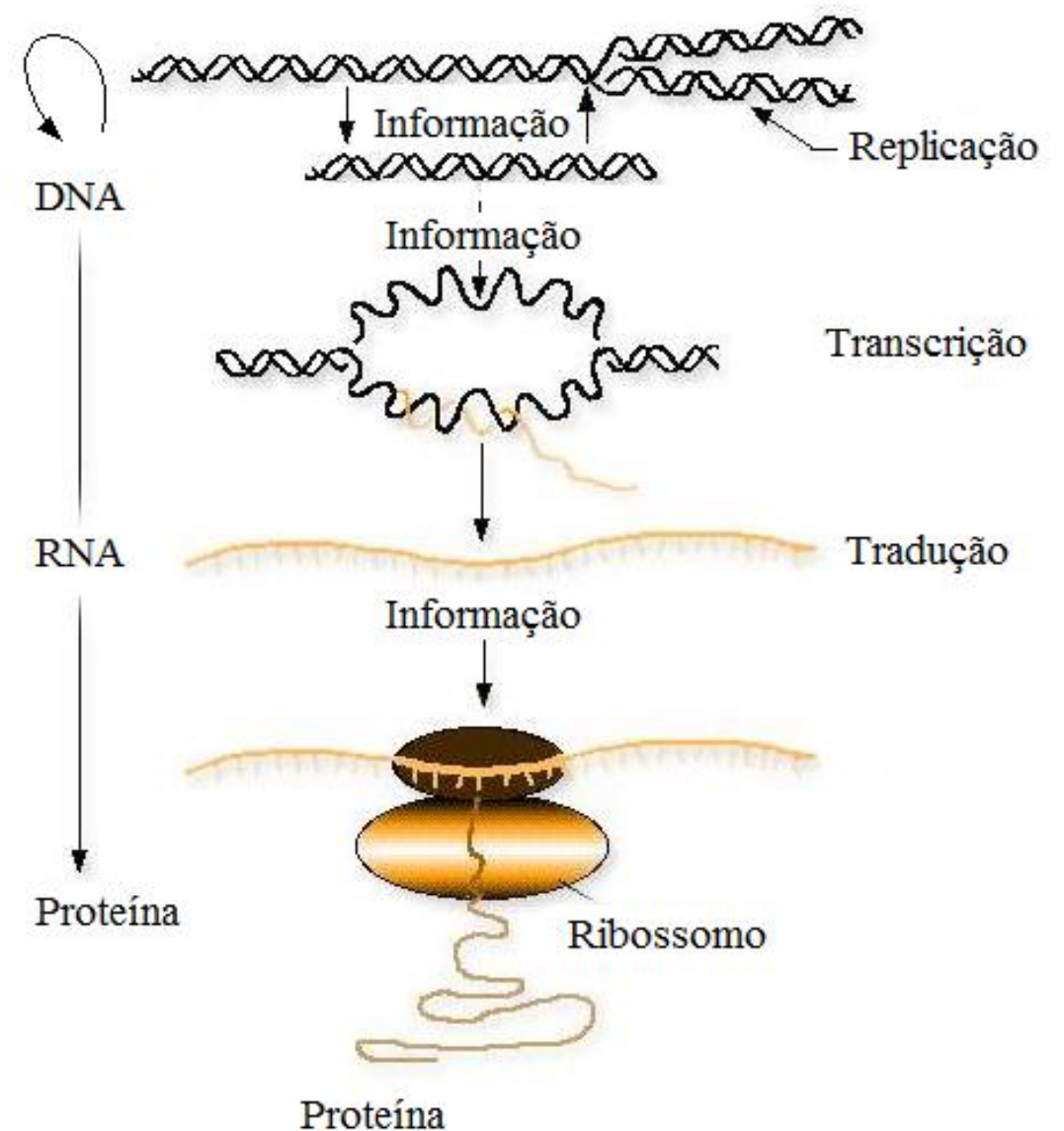

Figura 2. Dogma Central da Biologia Molecular. 
Para produção de novas proteínas, as informações genéticas no DNA são $\operatorname{transcritas}^{3}$ em um produto intermediário, mRNA (messenger Ribonucleic Acid), no núcleo da célula. Por sua vez, os mRNA são responsáveis por transportar as informações até os ribossomos, uma organela do citoplasma da célula, onde ocorrerá a tradução ${ }^{4}$ das mesmas para geração de novas proteínas.

A expressão gênica de um particular gene é mensurada a partir da quantidade aproximada de cópias de mRNA deste gene presente na célula. Considera-se que o gene está altamente expresso quando há abundância de seu mRNA na célula, ou seja, quando o mesmo está sendo transcrito em grande quantidade. Desta forma, é possível relacionar a expressão gênica (quantidade de mRNA) do particular gene com a quantidade de proteína que este produz.

Uma vez que organismos de mesma espécie contêm em todas as moléculas de DNA os mesmos genes, mas possivelmente constituídos de algumas alterações nas bases e com expressões diferentes, uma maneira de se investigar diferenças entre dois organismos diagnosticados como, por exemplo, cancerígeno e não cancerígeno, a partir de seus padrões de expressão gênica, é mensurar a quantidade de RNA ou de proteínas na célula transcritas e traduzidas por cada gene nas duas condições e procurar aqueles genes que se expressam diferencialmente.

\subsection{A técnica de Microarrays e a sua importância}

A técnica de Microarrays faz parte de uma nova e promissora classe de biotecnologias, a qual permite o monitoramento simultâneo dos níveis de expressão gênica de milhares de genes. Nesta técnica, tal monitoramento é realizado a partir da execução de procedimentos laboratoriais que possibilitam a mensuração simultânea da quantidade (abundância) de transcrições de mRNA realizadas pelos milhares de genes em estudo sobre uma particular célula ou tecido amostral de interesse (Brown \& Botstein, 1999; Lockhart \& Winzeler, 2000).

\footnotetext{
${ }^{3}$ Processo denominado por "Síntese de RNA"

${ }^{4}$ Processo denominado por "Síntese de Proteínas"
} 
Para a quantificação das transcrições de mRNA a técnica de Microarrays faz uso de um artefato engenhoso. Em linhas gerais, nos experimentos de Microarrays, se tem duas fases principais: preparação da lâmina de Microarrays e preparação das amostras de tecido extraídas de grupos caso e controle ou mais do que dois (Brown \& Botstein, 1999; Brazma et al., 2001; Kerr \& Churchill, 2001).

Inicialmente, os probes, seqüências complementares de DNA para os genes em estudo, são fixados nos spots (cavidades físicas geometricamente espaçadas) presentes na superfície do array (em geral uma lâmina de vidro) (ver Figura 3). Sobre a amostra de interesse, digamos uma biópsia de tumor, é realizada a extração de amostras de mRNA, as quais, posteriormente, são submetidas a um processo denominado por "identificação" que tem por objetivo agregar colorações às mesmas.

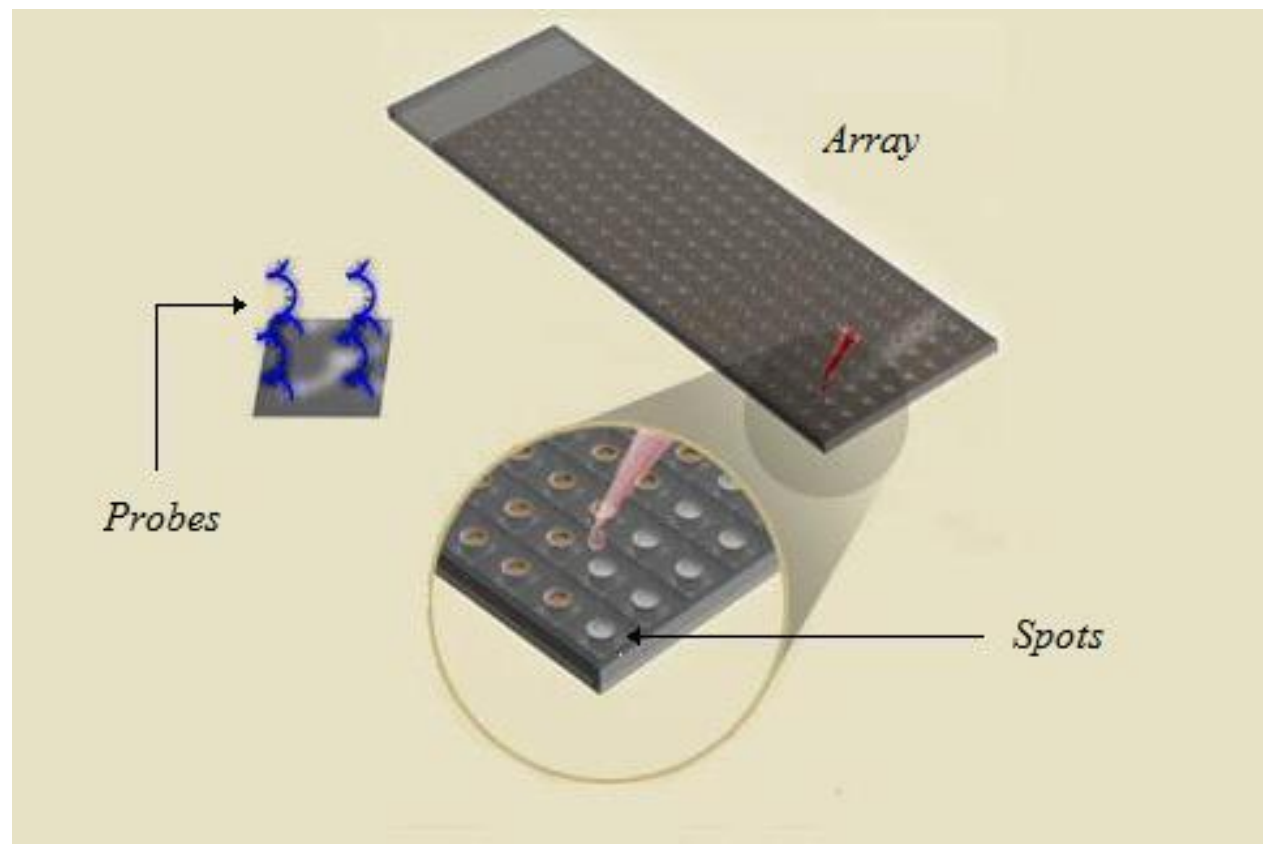

Figura 3. Ilustração: Array, probes e spots.

Em estágio secundário, as amostras de mRNA identificadas são despejadas sobre o array e, após a realização do processo de hibridização, no qual ocorre a ligação entre as amostras de mRNA e os probes, e a retirada do material não hibridizado (processo de lavagem do array - "wash”), se torna possível extrair os níveis de expressão gênica dos genes em estudo a partir da leitura de intensidade luminosa presente em cada spot do 
array, uma vez que as ligações entre as amostras de mRNA e os probes preservam as colorações inicialmente introduzidas nas amostras.

Por sua vez, a leitura de intensidade luminosa é realizada por meio de um scanner de alta resolução, o qual se desloca por toda a superfície do array identificando as diferentes intensidades de coloração presentes em cada spot. Como resultado, para cada spot do arrray, o scanner fornece uma imagem composta por milhares de pixels (em geral $50 \times 50)$, a qual, após passar pelos processos de segmentação (identificação) e quantificação (sumarização) representará o valor numérico associada à intensidade luminosa do correspondente probe. Desta forma, estando a quantificação de intensidade luminosa associada à quantidade de mRNA transcritos, seus valores representam os níveis de expressão gênica daqueles milhares de genes fixados no array sobre a amostra de interesse avaliada.

Apesar da avançada tecnologia envolvida em cada uma das fases do experimento de Microarrays, os dados obtidos sofrem a influência de muitas fontes de variações sistemáticas indesejáveis, o que exige a aplicação de técnicas computacionais e metodologias de análise estatística para extração das informações contidas nestes dados. Ao se iniciar os procedimentos descritos anteriormente, os recursos computacionais empregados dependem diretamente das tecnologias (por exemplo, tipo de array adotado: vidro, folha de quartzo ou membrana de nylon) e configurações experimentais adotadas (por exemplo, configuração dos parâmetros do scanner), entretanto, à medida que valores confiáveis de expressão gênica emergem, se iniciam as buscas e/ou aplicações de metodologias estatísticas que tornem possível a exploração das informações coletadas, gerando neste momento grandes desafios aos pesquisadores que fazem uso desta técnica. Por exemplo, para os Estatísticos, um desafio inerente aos experimentos de Microarrays é a discrepância entre a enorme quantidade de genes analisados (centenas de milhares) e a pequena quantidade de unidades experimentais consideradas (dezenas), resultando no paradigma denominado por "large $p$, small $n$ " (West, 2003), ou o simples fato das medidas de expressão gênica freqüentemente serem mensuradas com uma grande quantidade de variação sistemática indesejada (Li \& Hong, 2001). 
Como conseqüência imediata destes desafios surge a necessidade de se aprimorar as técnicas já existentes ou a criação de novas metodologias de análise, uma vez que ferramentas tem sido usadas amplamente.

\section{Diferentes técnicas (plataformas) de Microarrays}

Este tópico pode ser amplamente discutido, entretanto, neste trabalho não se tem por objetivo apresentar de forma detalhada as diferentes técnicas de Microarrays disponíveis. Contudo, de modo a auxiliar a compreensão das exposições posteriores, se apresenta resumidamente duas dentre as principais técnicas utilizadas, a saber: as técnicas de Microarrays baseadas em oligonucleotídeos e aquelas baseadas em cDNA.

\section{Microarrays com Oligonucleotídeos}

Os experimentos de Microarrays com Oligonucleotídeos se caracterizam por utilizarem curtas seqüências de probes fixadas nos spots dos arrays. Em geral, cada array contém entre 11 a 20 probes que representam fragmentos de milhares de genes do genoma, os quais são compostos por 25 pares de bases nitrogenadas. Além disso, como no caso das plataformas com oligonucleotídeos da empresa Affymetrics, em cada spot os probes (fragmentos) são fixados aos pares, os quais são nomeados por Perfect-Match $(P M)$ e Miss-Match (MM). PM é o nome dado ao probe com seqüência de bases nitrogenadas complementar àquela do gene que se tem interesse em estudar, enquanto $M M$ é o nome dado ao probe representado por uma seqüência de bases nitrogenadas muito próximas àquela do gene de interesse, com uma alteração na base nitrogenada central da seqüência (Chen et al, 2004). Para se obter o nível de expressão gênica de um específico probe, a medida PM é corrigida pela medida MM. Usualmente, se calcula a média aritmética das diferenças entre os níveis de expressões $P M$ e $M M$ mensuradas em todos os spots no qual o particular probe esteja sendo analisado (Satagopan \& Panageas, 2003), entretanto, outras metodologias mais aprimoradas podem ser encontradas em Schadt et al. (2001), Bolstad et al. (2002), Irizarry et al. (2003), Do \& Choi (2006), Calza et al. (2008), entre outros. 
Outras plataformas com oligonucleotídeos, como é o caso daquelas produzidas pela empresa CodeLink ${ }^{\mathrm{TM}}$, utilizam apenas as seqüência $P M$ fixadas nos spots, além disso, o tamanho destas sequiência podem ser mais longas e não necessariamente existem várias representações do mesmo gene nos spots.

Uma particularidade dos experimentos de Microarrays com oligonucleotídeos está no fato de uma única amostra ser processada em cada array, isto é, as leituras de expressão gênica realizadas em cada array correspondem a um único canal de coloração.

\section{Microarrays com cDNA}

A metodologia utilizada em experimentos de Microarrays com cDNA é diferente daquela empregada em experimentos de Microarrays com oligonucleotídeos, embora se faça uso dos mesmos princípios (fixação dos probes nos arrays, identificação das amostras, leitura dos níveis de expressão). Os experimentos de Microarrays com cDNA se caracterizam por utilizarem longas sequiências de probes fixadas nos spots dos arrays. Hoje em dia, probes de cDNA para construção de arrays podem ser produzidos a partir de bibliotecas de cDNA comercialmente disponíveis, as quais podem garantir uma representação muito próxima do genoma completo do organismo a ser analisado nos arrays (Coe \& Antler, 2004).

Nos experimentos de Microarrays com cDNA duas amostras são processadas ao mesmo tempo no array. A preparação destas amostras se inicia com a extração de mRNA do material a ser analisado sendo este, em etapa posterior, reversamente transcrito em cDNA. A identificação das amostras requer a utilização de diferentes colorações sendo, em geral, adotadas as cores: verde fluorescente $\left(\mathrm{Cy}^{5}\right)$ e vermelho fluorescente $\left(\mathrm{Cy}^{6}\right)$. Uma vez que estas amostras tenham sido identificadas com colorações diferentes, as mesmas podem ser combinadas e hibridizadas no mesmo array. No processo de hibridização as amostras irão competitivamente se unir aos probes fixados no array e, como resultado, dependendo dos níveis de expressão das amostras, se terá um padrão de coloração presente em cada spot. Por exemplo, se a

\footnotetext{
${ }^{5}$ Cianina 3

${ }^{6}$ Cianina 5
} 
coloração Cy3 for utilizada para identificação de uma amostra controle e a coloração Cy5 para identificação de uma amostra experimental, caso ocorra maior quantidade de transcrição de mRNA da amostra controle, então, maior será a quantidade de Cy3 presente no probe e, por decorrência, o padrão de coloração presente no spot aproximarse-á da coloração verde fluorescente. Caso ocorra a condição contrária, o padrão de coloração presente no spot aproximar-se-á da coloração vermelho fluorescente. Quando as quantidade de transcrição de mRNA de ambas as amostras estiverem próximas, as colorações irão de certa forma se anular, e o padrão de coloração presente no spot se aproximará do amarelo fluorescente.

\section{Algumas vantagens e desvantagens ao se utilizar as técnicas de Microarrays com Oligonucleotídeos e cDNA}

Não é fácil julgar se experimentos de Microarrays com oligonucleotídeos são superiores àqueles com cDNA, ou vice-versa, uma vez que ambos apresentam algumas características distintas que, de certo modo, podem ser interpretadas como vantagens e/ou desvantagens dependendo do cenário em que se pretende utilizar o experimento de Microarrays, as quais são apresentadas a seguir.

Em experimentos de Microarrays com Oligonucleotídeos o fato de se ter uma ou mais amostras aberrantes provenientes, por exemplo, de problemas ocorridos no estágio de coloração ou hibridização, não afetará as medidas derivadas das demais amostras, pois, como já exposto anteriormente, cada amostra é processada em um único array. Por outro lado, a ocorrência de amostras aberrantes em experimentos de Microarrays com cDNA pode afetar drasticamente a mediada das outras amostras, pelo simples fato de duas amostras serem processadas no mesmo array.

Outra vantagem dos experimentos de Microarrays com oligonucleotídeos está no fato das seqüencias de DNA especificadas nos probes serem sempre conhecidas, o que pode não ser verdade para os experimentos de Microarrays com cDNA, uma vez que longas seqüências são especificadas nos probes. 
Em geral, experimentos de Microarrays com cDNA reduzem significantemente a quantidade de arrays necessários para se efetuar as comparações entre as amostras de interesse, pois duas amostras são processadas em um único array e, inclusive, podem auxiliar na redução do custo operacional do experimento, uma vez que arrays de oligonucleotídeos possuem custos mais elevados.

Quando o interesse é a comparação de apenas duas amostras, os experimentos de Microarrays com cDNA podem levar a análises mais precisas já que se trata de um delineamento pareado com os dois tratamentos avaliados na mesma unidade experimental.

Uma vantagem do experimento com oligonucleotídeos (da Affymetrics) está no fato de se fazer a correção da medida de expressão gênica se comparando as respostas $P M$ e $M M$ em cada spot (Irizarry et al., 2003).

\subsection{Problemas técnicos inerentes aos experimentos de Microarrays}

Como já apresentado, a técnica de Microarrays é empregada com o propósito de se mensurar o nível de expressão gênica em milhares de genes simultaneamente. Entretanto, por não ser possível mensurar fisicamente expressões gênicas diretamente no interior da célula, esta técnica faz uso de avançados recursos laboratoriais compostos por múltiplos estágios, onde cada estágio pode ser considerado um potencial causador de fontes de variações indesejadas (denominadas também por ruídos ou perturbações sistemáticas) que acabam sendo incorporadas às medidas de expressões gênicas de interesse. De fato, este é um problema técnico inerente aos experimentos de Microarrays, restando ao pesquisador responsável pelo planejamento do experimento a tarefa de estabelecer as medidas, pré e pós coleta de dados, necessárias para amenizar/eliminar, na medida do possível, estas variações indesejadas.

Usualmente, a variabilidade mensurada em expressões gênicas é decomposta em três categorias: variações biológicas, variações técnicas e variações residuais (Novak et al., 2002; Churchill, 2002). Variações biológicas provêm de diferenças inerentes às expressões gênicas, estas que se distinguem de indivíduo para indivíduo em virtude de 
fatores genéticos, biológicos e/ou ambientais. Por outro lado, as variações técnicas se originam do simples uso do experimento de Microarrays. Nestes experimentos potenciais fontes de variações técnicas incluem: o processo de preparação das amostras - extração e purificação de RNA, sintetização de cDNA, identificação das amostras através da incorporação de corantes (diferentes colorações ou quantidades entre os materiais utilizados); o procedimento de construção do experimento - número de probes, formato físico dos spots, geometria e fixação dos probes; o procedimento de hibridização - quantidade de cDNA aplicado no array e/ou temperatura de hibridização; o método de detecção - configuração dos parâmetros do scanner; hibridização cruzada; espúrios de intensidade radiada pelos spots vizinhos; entre outras. Por fim, as variações residuais são decorrentes de fatores não controlados de origem desconhecidas. Como as variações biológicas, técnicas e residuais são assumidas mutuamente independentes, a variação presente nas medidas de expressão gênica é dada pela soma destas três variações (componentes) (Chen et al., 2004).

Em experimentos de Microarrays, também é comum a distinção entre as variações que ocorrem dentro do array e as variações entre arrays. Variações dentro do array podem ser causadas, por exemplo, pela presença de arranhões e/ou sujeiras na superfície dos mesmos, diferenças na eficiência de identificação das amostras, viés relacionados à dependência espacial (posicionamento dos genes nos spots), entre outras circunstâncias já citadas. Quando a amostra despejada no array procede de única extração, a variação interna mensurada é atribuída à variação técnica. Por outro lado, as

variações observadas entre arrays podem estar associadas a fatores biológicos, ambientais e/ou técnicos.

\subsection{Desafios estatísticos e biológicos presentes nos experimentos de Microarrays}

O desafio Estatístico está na forma (escolha e aplicação de metodologias analíticas) com a qual as componentes de variância (biológica, técnica e residual) presentes neste tipo de experimento serão matematicamente tratadas. Por sua vez, o desafio Biológico está na complexidade com a qual o planejamento do experimento será feito e os resultados estatísticos serão interpretados. 
O delineamento do experimento de Microarrays marca o início do desafio estatístico. Apesar de não ser possível descrever uma recomendação universal apropriada para todas as situações experimentais, os princípios gerais de planejamento de experimentos estatísticos se aplicam aos experimentos de Microarrays (Smyth, 2003). Churchill (2004) apresenta e discute estes princípios em detalhes para experimentos de Microarrays de cDNA, os quais também se aplicam aos experimentos de Microarrays de Oligonucleotídeos. Neste trabalho será dada mais ênfase às questões das réplicas experimentais.

A introdução de réplicas no experimento é indispensável para se conhecer a precisão com a qual as expressões gênicas estão sendo mensuradas, pois as mesmas possibilitam o cálculo da variabilidade presente nos dados. Nos experimentos de Microarrays as réplicas podem ser incorporadas em diferentes níveis. Segundo Churchill (2002), por exemplo, os diferentes níveis de réplicas podem ser definidos e nomeados por: réplicas biológicas - duas ou mais unidades experimentais representando uma mesma condição biológica, réplicas técnicas - duas ou mais amostras extraídas de uma mesma unidade experimental, as quais são processadas em diferentes arrays e, réplicas de spot - dois ou mais spots representando um mesmo probe no array.

A Figura 4 foi apresentada em Churchill (2002) para ilustrar um experimento de Microarrays de cDNA onde estão presentes os três níveis de réplicas anteriormente citadas. Observe que neste experimento duas condições biológicas (tratamentos) foram avaliadas em 4 unidades experimentais (ratos) (presença de réplica biológica), sendo que de cada unidade experimental são extraídas duas amostras para análise (presença de réplica técnica), as quais foram processadas em arrays contendo réplicas de cada spot. 


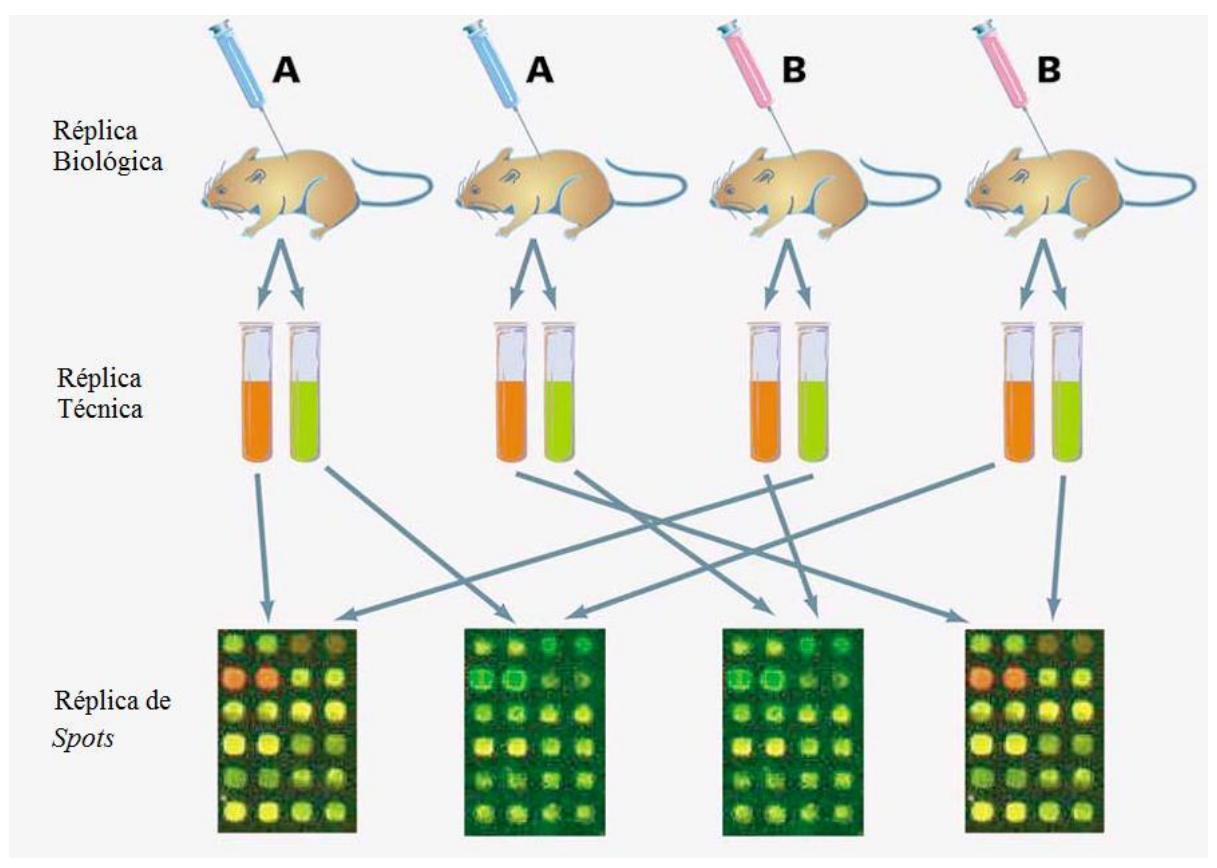

Figura 4. Representação das réplicas biológica, técnica e spots para um delineamento de Microarrays de cDNA.

Sob estas considerações, quando o propósito do experimento é determinar como os tratamentos afetam diferentes populações biológicas, os testes estatísticos devem se basear na variância biológica. Por outro lado, se o propósito é detectar variações dentro dos tratamentos presentes no experimento, os "testes estatísticos" devem se basear nas variações técnicas. Em geral, as réplicas biológicas são utilizadas para validar conclusões e as réplicas técnicas utilizadas na tentativa de se reduzir a variabilidade devido à técnica.

Uma vez conduzido o experimento e mensuradas as expressões gênicas, etapas subseqüentes consistem na análise exploratória destas medidas (no intuito de se conhecer, por exemplo, a distribuição dos valores de expressão gênica ou detectar vieses incorporados durante a execução do experimento) e aplicação de métodos de normalização às mesmas, discutidos a seguir.

A análise exploratória das medidas pode ser iniciada a partir do uso de técnicas de representação gráfica para os arrays, as quais propiciam, dentre outras coisas, avaliar o sucesso do experimento, auxiliam na escolha de ferramentas para futuras análises e ajudam a destacar problemas específicos ocorridos no experimento (Smyth, 2003). Por exemplo, em experimentos de Microarrays de cDNA, a mais óbvia representação gráfica é aquela na qual as duas intensidades das amostras identificadas com diferentes 
colorações, em geral verde (Cy3) e vermelha (Cy5), são sobrepostas (ver Figura 5), a qual fornece uma visualização geral sobre: o balanço de coloração para o conjunto de probes no array; uniformidade do processo de hibridização; uniformidade dos spots; visualização grosseira daqueles genes diferencialmente expressos entre duas amostras.

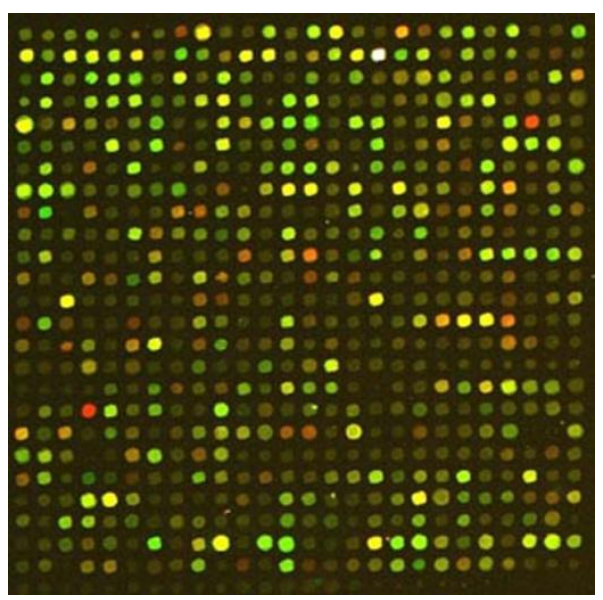

Figura 5. Representação visual das intensidades de expressão gênica mensurados em um experimento de Microarrays de cDNA.

Outras abordagens técnicas de representação gráfica envolvendo valores numéricos das intensidades gênicas incluem, por exemplo, os denominados MA-plots (Yang et al., 2002), os gráficos de dispersão, dispersão espacial e boxplots.

Em particular, o MA-plot tem se tornado uma ferramenta muito útil em análises de Microarrays. Estes gráficos são tipicamente utilizados na comparação de dois canais de coloração, dois arrays ou grupos de arrays (Bolstad, 2004). Outro fator importante agregado a esta ferramenta de representação gráfica está no fato da mesma ser utilizada em inúmeros processos de normalização de dados propostos na literatura (Dudoit et al. (2002), Yang et al. (2002) e Bolstad et al. (2003)).

O MA-plot contempla em sua ordenada as diferenças entre os logaritmos dos valores de expressão gênica e em sua abscissa os valores da média dos logaritmos das expressões gênicas, referentes a duas condições a serem comparadas. De forma geral, para experimentos de Microarrays com Oligonucleotídeos, o MA-plot pode ser formalizado da seguinte maneira: Defina $Y_{g j}$ como sendo o valor de expressão gênica 
do $g$ - ésimo gene observado no $j$ - ésimo array. Para comparar dois arrays, digamos $j$ e $j^{\prime}$, os valores de $M_{g}$ e $A_{g}$ são calculados, respectivamente, por $M_{g}=\log _{2}\left(Y_{g j}\right)-$ $\log _{2}\left(Y_{g j^{\prime}}\right)$ e $A_{g}=\frac{1}{2}\left[\log _{2}\left(Y_{g j}\right)+\log _{2}\left(Y_{g j^{\prime}}\right)\right]$ para cada spot ou fragmento genético, $g=1, \ldots, p$. Em análises de Microarrays, a base 2 logarítmica é utilizada por conveniência para que unidades de mudança em $M$ e $A$ representem duplicações no valor de expressão gênica entre as situações $j$ e $j^{\prime}$ (Bolstad, 2004).
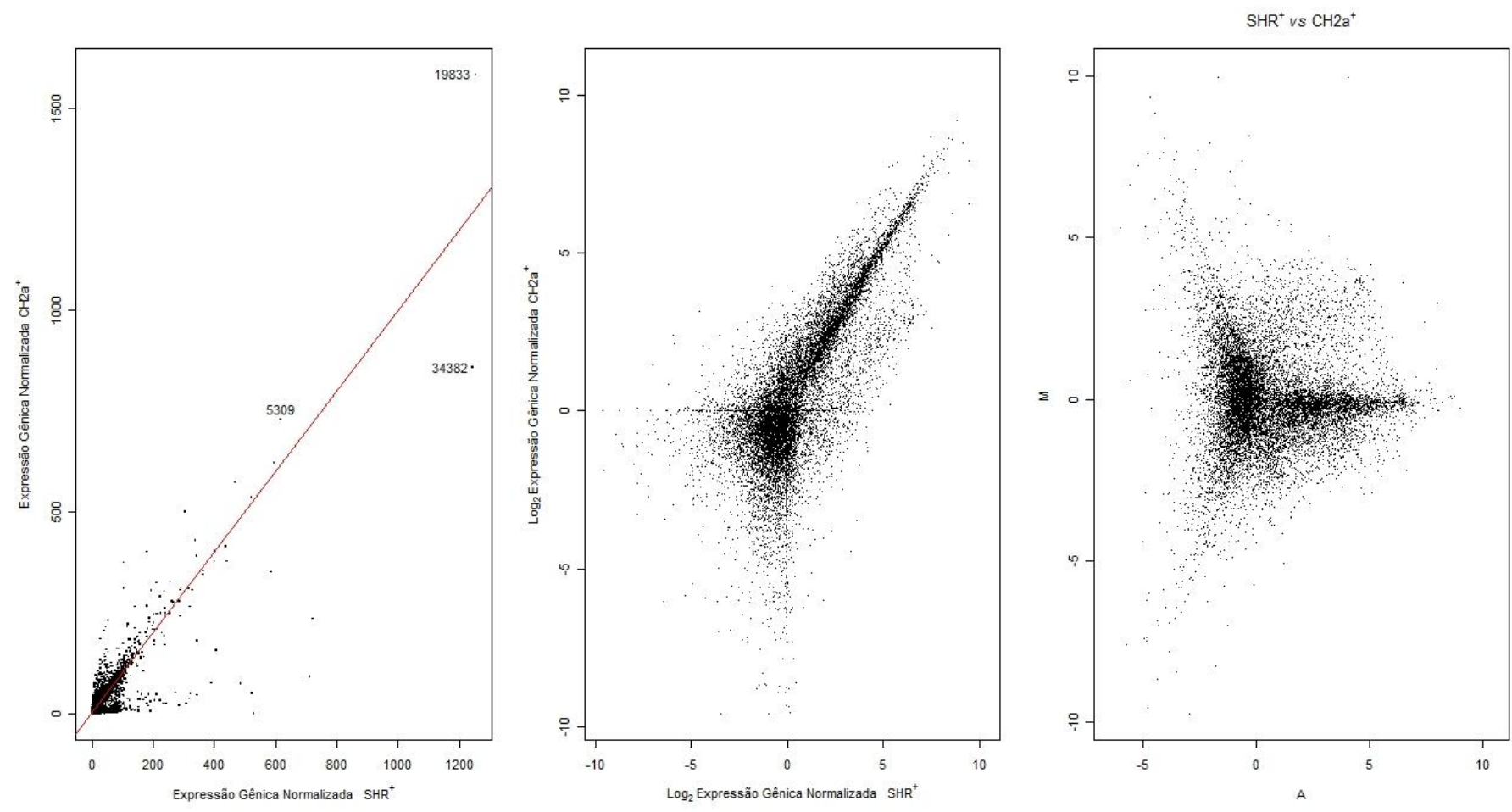

Figura 6. Ilustração - Gráficos de dispersão dos valores de expressão gênica (à esquerda) e logaritmo dos valores de expressão (central) e MA-plot (à direita) para o logaritmo dos valores de expressão gênica entre dois arrays.

É muito usual em Microarrays a verificação do padrão de dispersão dos valores de expressão gênica entre dois arrays por meio de técnicas gráficas como, por exemplo, os gráficos de dispersão. A Figura 6 ilustra exemplos de gráficos de dispersão construídos a partir de valores de expressão gênica de dois particulares arrays da base de dados que será analisada neste trabalho. Em particular, a Figura 6 contém os gráficos de dispersão dos valores de expressão gênica "brutos" (à esquerda), o gráfico de dispersão do logaritmo (base 2) dos valores de expressão gênica (central) e o MA-plot 
(à direita). O MA-plot representa a dispersão da variabilidade $(M)$ dos valores de expressão gênica na escala logarítmica (base 2) entre as amostras $j$ e $j^{\prime}$ pela média $(A)$ para o conjunto de todos os fragmentos genéticos. Note que este gráfico é simplesmente o gráfico de dispersão (central) após uma rotação de $45^{\circ} \mathrm{em}$ seu eixo. Vale notar também que o MA-plot possibilita identificar tendências não-lineares entre os valores de expressão gênica, comuns em Microarrays, as quais não podem ser notadas a partir do gráfico de dispersão dos valores de expressão gênica "brutos" (à esquerda). Em muitas ocasiões, o MA-plot é, inclusive, utilizado como um ferramental para se normalizar valores de expressão gênica (Yang et al., 2002).

De fato, uma dentre as aplicações do MA-plot está associada à verificação de tendências na distribuição das medidas de expressão gênica, uma vez que para este gráfico se espera no eixo das ordenadas uma disposição aleatória dos valores de expressão ao redor do valor zero (indicação de não haver tendências) (Chen et al., 2004) e comportamentos destoantes do esperado fornecem indícios de tendência. Quando tendências de superdispersão (quando a média e o desvio-padrão crescem juntos) ou provenientes de fontes de variação indesejáveis são detectadas é aconselhável a aplicação de métodos de normalização para correção dos dados e, como serão apresentados mais adiante, alguns métodos de normalização não-paramétrico fazem uso do MA-plot para este fim, abordagem que têm sido amplamente utilizada no contexto de Microarrays.

Outra utilização para o MA-plot inclui a verificação empírica de prováveis genes diferencialmente expressos entre os arrays, uma vez que genes, tipicamente, apresentam altos valores para a medida $A_{g}$ e alta variabilidade para o $\left|M_{g}\right|$. Desta forma, basta que o pesquisador especialista estabeleça valores de corte (classificação) para $A_{g}$ e $\left|M_{g}\right|$ para que se crie uma distinção entre genes diferencialmente expressos ou não.

Anterior e posterior ao estágio de análise exploratória dos valores de expressão gênica, as "regras" usualmente adotadas na análise de Microarrays consistem, respectivamente, da aplicação das denominadas correções pelo background (também referenciadas por ajuste de sinal) e da aplicação das técnicas de normalização às medidas de expressão gênica como meio de correção/suavização dos dados. 


\subsection{Métodos de correção e normalização}

\subsubsection{Correção pelo Background}

Bolstad (2004) define "correção pelo background" como sendo a aplicação de metodologias que visem: corrigir/eliminar os ruídos de background ${ }^{7}$ e os efeitos do processamento; corrigir os casos de hibridizações cruzadas ${ }^{8}$ nos arrays; ajustar as medidas das expressões para uma escala adequada ou de forma que estas estejam linearmente relacionadas com a concentração/abundância de mRNA.

A realização da correção pelo background dependerá da plataforma que se esteja utilizando e da metodologia escolhida. Em experimentos de Microarrays de cDNA esta correção pode ser realizada a partir das medidas de intensidade luminosa coletadas nos pixels que circunscrevem os spots. Por outro lado, em experimentos de Microarrays de Oligonucleotídeos como, por exemplo, aqueles produzidos pela empresa Affymetrix, a correção pelo background é efetuada utilizando os próprios valores de expressão gênica mensurados nos spots, isto porque nestes experimentos os arrays tipicamente possuem probes localizados muito próximos uns dos outros (alta densidade de probes por espaço nos arrays). A seguir duas metodologias dentre as propostas existentes para correção pelo background no contexto de experimentos de Microarrays com Oligonucleotídeos serão apresentadas de forma resumida.

\section{Modelos de Convolução RMA (RMA Convolution Model)}

Nos Modelos de Convolução RMA para correção do background a expressão gênica observada, $S$, é modelada como sendo a soma de duas componentes $S=X+Y$, com $X \sim \operatorname{Exp}(\alpha)$ representando a expressão gênica e $Y \sim N\left(\mu, \sigma^{2}\right)$ representando o background. Em particular, de modo a evitar a ocorrência de valores negativos se

\footnotetext{
${ }^{7}$ Entende-se por ruídos de background as intensidades luminosas mensuradas ao redor de um spot que não representa expressão gênica.

${ }^{8}$ Quando o material despejado no array se une ao probe sem que suas seqüências de bases nitrogenadas sejam complementares.
} 
assume $Y \geq 0$, sendo então $Y \sim N_{T_{0}}\left(\mu, \sigma^{2}\right)$ truncada em 0 . Desta forma, sob este modelo o valor de expressão gênica corrigido pelo background será dado por (Bolstad, 2004),

$$
E(X \mid S=s)=a+b \frac{\phi\left(\frac{a}{b}\right)-\phi\left(\frac{s-a}{b}\right)}{\Phi\left(\frac{a}{b}\right)+\Phi\left(\frac{s-a}{b}\right)-1}
$$

com $a=s-\mu-\sigma^{2} \alpha, b=\sigma, \phi(\cdot)$ e $\Phi(\cdot)$ representando, respectivamente, a função densidade de probabilidades e a função de distribuição acumulada da distribuição normal padrão.

\section{Correção Específica por Local (Location Specific Correction)}

Ao se empregar a Correção Específica por Local se tem por objetivo ajustar os valores de expressão gênica para cada probe presente no array a partir da remoção de um ruído de background global. Nesta metodologia, inicialmente, se faz a divisão da superfície do array em, por exemplo, $K$ regiões (grade) (ver Figura 7). Em seguida, para cada região do array é efetuada a estimação do ruído de background que é uma medida resumo como, por exemplo, a mediana ou a média. Por fim, o valor de expressão gênica de cada probe é ajustado com base numa média ponderada calculada a partir do valor de background de cada região, sendo esta ponderação dependente da distância entre a posição $(x, y)$ do probe e os centróides das $k$ regiões. Em particular, as ponderações são dadas por (Bolstad, 2004),

$$
w_{K}(x, y)=\frac{1}{d_{K}^{2}(x, y)+\text { smooth }}
$$

onde $d_{K}$ é a distância euclidiana entre a localização $(x, y)$ do probe e o centróide da região $K$ e smooth é um valor para suavização igual a 100 (padrão). 


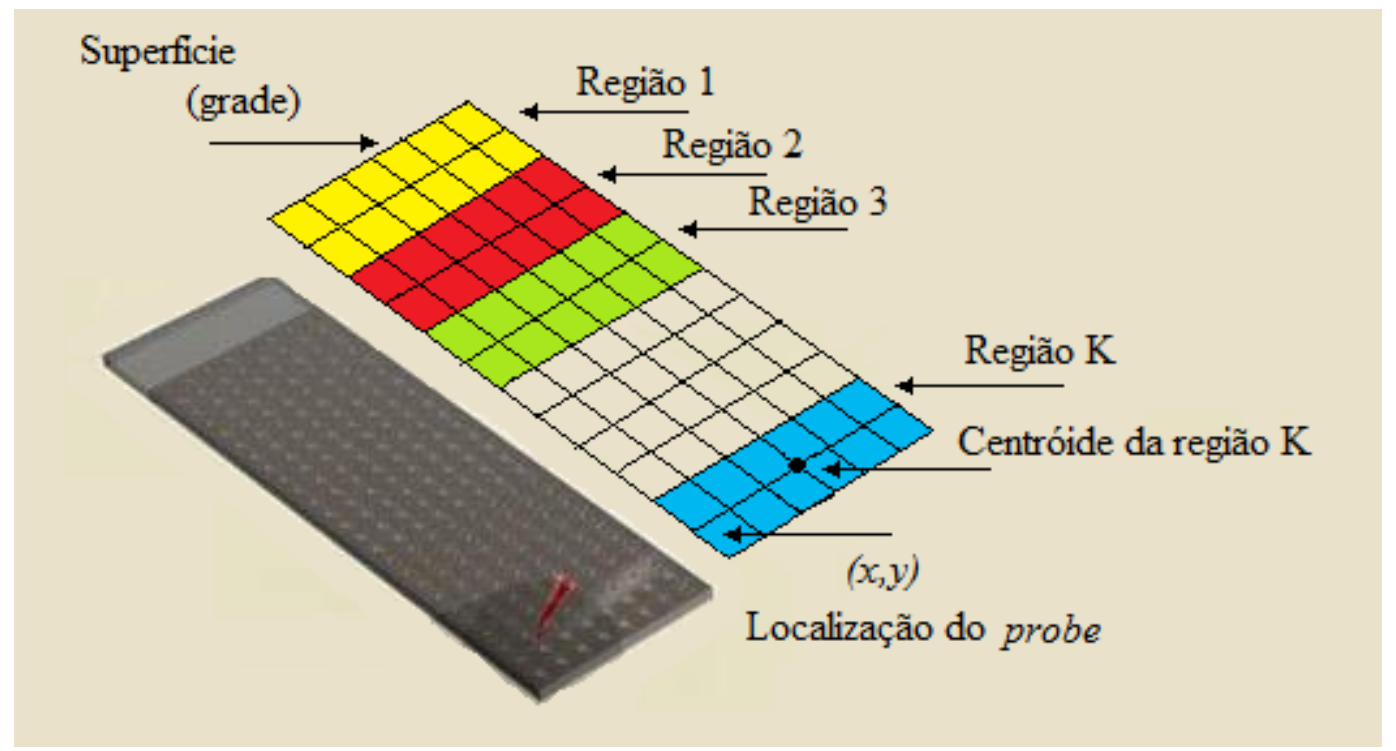

Figura 7. Ilustração da divisão da superfície de um array em K regiões retangulares para aplicação da metodologia de Correção Específica por Local para correção do background.

O algoritmo abaixo é apresentado por Bolstad (2004) como proposta para estimação dos valores de background utilizando a metodologia de Correção Específica por Local para realização dos ajustes dos valores de expressão gênica para cada probe presente no array.

\section{$\underline{\text { Etapa A }}$}

Seja $P_{x, y}$ a expressão gênica do probe localizado na posição $(x, y)$ do array

Divida o array em $K$ regiões retangulares (padrão $K=16$ )

Para $k=1$ até $K$ faça

Para a região $k$ calcule a média $b_{k}$ (denomine por background para a região $k$ ) e o desvio-padrão $s_{k}$ (denomine por ruído para a região $k$ ) considerando os $2 \%$ dos probes com os menores valores de expressão gênica

\section{Encerrar o ciclo}

\section{$\underline{\text { Etapa B }}$}

Para todos os probes do array faça 


$$
\begin{aligned}
& \text { Calcular } B(x, y) \text { e } N(x, y), \operatorname{logo}, \\
& P_{x, y}=\max \left(P_{x, y}-B(x, y), N_{f} * N(x, y)\right)\left(\text { padrão } N_{f}=0,5\right)
\end{aligned}
$$

\section{Encerrar o ciclo}

onde $B(x, y)$ é a média ponderada de $b_{k}$ na localização $(x, y)$ e $N(x, y)$ é a média ponderada de $s_{k}$ na localização $(x, y)$.

As duas metodologias para correção do background apresentadas anteriormente, bem como as metodologias Mismatch Ideal (Ideal Mismatch) e LESN (Correcting Low Intensity Signal) e Ajuste pela Curva Padrão (Standard Curve Adjustment) são apresentadas e discutidas com maior rigor em Bolstad (2004). Também, Schadt et al. (2001) e Irizarry et al. (2003) apresentam métodos alternativos para correção do background para experimentos de Microarrays com Oligonucleotídeos. Já, para experimentos de Microarrays com cDNA outras metodologias de correção pelo background são pospostas, por exemplo, Yang et al. (2002), Smyth \& Speed (2003), Yin et al. (2005), Sanden \& Burzykowski (2006).

\subsubsection{Métodos de normalização}

Outras ferramentas empregadas para correção das medidas de expressão gênica são as técnicas de normalização. Yang et al. (2002) define normalização como sendo o processo de remoção das fontes de variação indesejadas que afetam as medidas de expressão gênica. Atualmente, distintas técnicas de normalização paramétrica e nãoparamétrica estão propostas na literatura, estando a escolha de determinada técnica diretamente relacionada ao tipo de variação indesejada que se tem interesse em remover/atenuar. Por exemplo, podem ser aplicadas técnicas de normalização que consideram características físicas do experimento como: a localização na qual os genes estão fixados nos spots (na tentativa de se eliminar tendências espaciais), ou, também, o desgaste dos materiais (agulhas) utilizados para fixação dos probes nos arrays, dentre outras.

Basicamente, os métodos de normalização podem ser definidos em duas classes: aqueles que utilizam informações de todos os arrays (complete data methods) e aqueles 
que utilizam um array como referência (baseline methodos) e a partir deste os demais arrays são normalizados, (Bolstad, 2004). A seguir serão apresentadas algumas dentre as técnicas de normalização para experimentos de Microarrays com Oligonucleotídeos disponíveis na literatura.

\section{Complete data Methods}

\section{Normalização Quantílica}

Ao se aplicar a Normalização Quantílica o que se busca é igualar a distribuição empírica dos valores de expressão gênica dos arrays. Uma vez construído um gráfico quantil-quantil para dois vetores com a mesma distribuição se espera que os pontos no plano cartesiano estejam dispostos segundo uma reta diagonal passando pela origem com inclinação de 45 graus. Agora, ao se construir este gráfico considerando $\mathrm{n}$ vetores com a mesma distribuição é de se esperar que seus pontos estejam sobrepostos sobre o vetor $\left(\frac{1}{\sqrt{n}}, \ldots, \frac{1}{\sqrt{n}}\right)$. A extensão para o caso multidimensional levou à elaboração do algoritmo de Normalização Quantílica apresentado a seguir (Bolstad, 2004).

\section{$\underline{\text { Algoritmo }}$}

A1: Dados $n$ arrays de comprimento $p$, construa a matriz $X$ de dimensão $p \times n$ onde cada coluna representa um array

A2: Ordene cada coluna de $X$ para obter $X_{\text {ordenado }}$

A3: Calcule a média nas linhas de $X_{\text {ordenado }}$ e substitua estes valos a cada elemento da linha para obter $X_{\text {ordenado }}^{\prime}$ uniformizada

A4: Para obter a matriz $X$ normalizada retorne os valores de cada coluna de $X_{\text {ordenado à }}^{\prime}$ posição original (inicial) de $X$

\section{Loess Cíclico}


A normalização dos arrays através do método de Loess Cíclico é realizada a partir de comparações pareadas. A normalização dos arrays pelo método Loess Cíclico é uma generalização do método de Loess Global descrito em Yang et al. (2002) para o contexto de Microarrays com cDNA. Para cada combinação de pares de arrays é construído um gráfico MA sobre o qual se realiza o ajuste da função de Loess. Este processo de normalização pareada dos arrays é ciclicamente repetido até que se tenha obtido um critério de convergência ou até que um ciclo máximo de iterações estabelecido seja alcançado. Usualmente, uma ou duas iterações englobando todas as comparações são necessárias para que a convergência seja atingida, sendo esta mesurada pela quantidade de ajustes realizados nos valores de expressão gênica na atual iteração. Um fator desfavorável na utilização desta metodologia está na necessidade de se ajustar uma grande quantidade de funções conforme se aumenta o número de arrays utilizados no experimento. Uma alternativa para agilizar tais ajustes é a utilização de um subconjunto dos dados, o qual pode ser selecionado por diferentes métodos (ver Schadt et al. (2001)). O algoritmo de normalização Loess Cíclico é apresentado a seguir, onde $i$ e $j$ são índices relacionados aos arrays e $k$ o índice relacionado aos probes.

Construa uma matriz $X_{p \times n}$ com colunas representando os arrays e as linhas os probes Faça a transformação nos dados $X \leftarrow \log _{2} X$

\section{Repita}

$$
\begin{aligned}
\text { Para } i=1 \text { até } n-1 \text { faça } \\
\qquad \text { Para } j=i+1 \text { até } n \text { faça }
\end{aligned}
$$

Para $k=1$ até $p$ faça

Calcule $M_{k}=x_{k i}-x_{k j}$ e $A_{k}=\frac{1}{2}\left(x_{k i}+x_{k j}\right)$

\section{Encerrar ciclo}

Ajuste a curva de Loess para o gráfico MA e chame o ajuste de $\hat{f}$ Para $k=1$ até $p$ faça

$$
\begin{aligned}
& \widehat{M}_{k}=\hat{f}\left(A_{K}\right) \\
& a_{k}=\frac{M_{k}-\widehat{M}_{k}}{n} \\
& x_{k i}=x_{k i}+a_{k} \text { e } a_{k j}=x_{k i}-a_{k} \\
& \text { Encerrar o ciclo }
\end{aligned}
$$




\section{Encerrar o ciclo}

\section{Encerrar o ciclo}

até que a convergência ou o número de iterações estabelecidas seja atingido Calcule o anti-logaritmo $X \leftarrow 2^{X}$.

\section{Baseline Methodos}

\section{Método Linear/Escalar}

A normalização através do Método Linear/Escalar tem por objetivo realizar uma transformação nos dados de modo que todos os arrays possuam o mesmo valor mediano de expressão gênica. Isto seria equivalente a selecionar um array e ajustar modelos de regressão linear (desconsiderando o intercepto) entre cada array e o array escolhido, tendo a função ajustada o papel de realizar a normalização entre os arrays. Por exemplo, os software da empresa Affymetrix (versões 4.0 e 5.0) disponibilizam esta metodologia de normalização com uma simples alteração - remoção de $2 \%$ dos menores e maiores valores de expressão gênica presentes no array. O algoritmo de normalização pelo Método Linear/Escalar é apresentado a seguir.

Construa uma matriz $X_{p \times n}$ com colunas representando os arrays e as linhas os probes Escolha uma coluna de $\mathrm{X}$ representando o array de referência, digamos a coluna $j$ Calcule a média aparada (trimmed) dos valores de expressão gênica da coluna $j$ e chame de $\tilde{X}_{j}$

Para $i=1$ até $n, i \neq j$ faça

Calcule a média aparada (trimmed) dos valores de expressão gênica da coluna $i$ e chame de $\tilde{X}_{i}$

Calcule $\beta_{i}=\frac{\tilde{X}_{j}}{\tilde{X}_{i}}$

Multiplique os elementos da coluna $i$ por $\beta_{i}$.

\section{Encerrar o ciclo}

\section{Método Não-Linear}


Em muitas situações a utilização de métodos lineares para normalização dos valores de expressão gênica não são adequadas. Schadt et al. (2001) afirmam ser bastante comum encontrar diferenças de 10 - 50\% na inclinação angular que descreve a relação entre os valores de expressão gênica dos arrays visualizada em um gráfico de dispersão, enfatizando ser natural neste contexto a substituição dos métodos lineares pelos métodos não-lineares de regressão. Como alternativas aos métodos de normalização linear, uma diversidade de métodos não-lineares tem sido proposta por diversos autores como, por exemplo, Running Median Lines (Li \& Hong, 2001), Crossvalidated Splines (Schadt et al., 2001), Loess Smoothers (Bolstad et al., 2003), entre outros. Em linhas gerais, o algoritmo para normalização através de métodos nãolineares é apresentado a seguir.

Construa uma matriz $X_{p \times n}$ com colunas representando os arrays e as linhas os probes Escolha uma coluna de $X$ representando o array de referência, digamos a coluna $j$

Para $i=1$ até $n, i \neq j$ faça

Ajuste uma função não-linear para mapear a relação entre a coluna $i$ e a coluna $j$ (array de referência) e chame de $\hat{f}_{i}$

Os valores normalizados para a coluna $j$ serão dados por $\hat{f}_{i}\left(X_{j}\right)$

\section{Encerrar o ciclo}

É evidente que, frente às diversas fontes de variação presentes em experimentos de Microarrays (ver, por exemplo, Hartemink et al. (2001)), se justifica a necessidade em se aplicar uma ou mais técnicas de normalização aos valores de expressão gênica mensurados, sendo bastante comum a utilização das técnicas de normalização que considerem as variações internas (dentro) de cada array e as variações entre arrays. Uma vez que as fontes de variação contribuem significantemente (no sentido negativo) na leitura dos valores presentes nos arrays, a normalização é o primeiro passo crítico a ser realizado em qualquer análise de expressão gênica (Hill, 2001). Vale frisar que a etapa de normalização das expressões gênicas também pode ser considerada como desafiadora, uma vez que a precisão das análises posteriores, as quais, provavelmente, resultarão em afirmações científicas, dependem diretamente da eficiência atingida nesta etapa. 
Considerando que foi empregado um delineamento cuidadoso (ver Churchill (2002)) para o experimento e após realizar as etapas de análise exploratória e normalização das medidas de expressão gênica, se inicia o processo de análise estatística para identificação de genes DE. Nesta fase, uma enormidade de técnicas estatísticas pode ser empregada, estando a escolha das mesmas relacionada ao objetivo do estudo e ao tipo de delineamento utilizado. 


\section{Capítulo 3}

\section{Metodologias de análise estatística para experimentos de}

\section{Microarrays}

Não foram precisos muitos anos para que a tecnologia de Microarrays passasse a ser adotada na maioria das pesquisas de biologia molecular. Ao mesmo tempo, as metodologias de análise estatística para Microarrays progrediram da simples avaliação visual dos resultados à grande quantidade de artigos publicados que descrevem supostamente novos algoritmos para análise de mudanças nas expressões gênicas.

Dentre as inúmeras metodologias de análises de dados para Microarrays a mais simples abordagem é feita através das medidas denominadas por fold-change. A complexidade das análises envolvidas em Microarrays diz respeito às técnicas de normalização dos dados aplicadas para eliminar fontes de variação externas e às técnicas de correção nas estatísticas de teste devido à necessidade de se realizar múltiplos testes. Muito da aplicação destas metodologias está diretamente vinculada ao objetivo do estudo e às características do experimento (por exemplo, delineamento experimental e plataforma de Microarrays). Por exemplo, quando o interesse do estudo está direcionado para a descoberta de grupos de "genes" com padrões de expressões gênicas similares, usualmente, se faz uso de técnicas de análise de agrupamentos como aquelas descritas em McLachlan \& Basford (1988) ou Fraley \& Raftery (1998). Por outro lado, quando o objetivo está vinculado ao desenvolvimento de modelos de classificação, comum em estudos em que se deseja distinguir dois ou mais tipos de cânceres, se faz uso de técnicas de análise discriminante como aquela proposta por GUO et al. (2006). Todavia, em grande parte dos estudos de Microarrays se tem por objetivo encontrar aqueles "genes" DE através de metodologias que agreguem significância às classificações como, por exemplo, os modelos de Analise de Variância - ANOVA (Churchill, 2003).

A seguir serão apresentadas algumas dentre as metodologias disponíveis de análise estatística utilizadas em Microarrays, as quais objetivam evidenciar genes DE avaliados sobre duas ou mais condições experimentais. Indispensavelmente, também 
será discutido o problema de múltiplos testes presente em experimentos de Microarrays e possíveis soluções para contornar este problema.

\subsection{Genes diferencialmente expressos}

Dentre os objetivos da análise dos dados de Microarrays um grande interesse está na identificação daqueles "genes" que manifestem consideráveis evidências de estarem DE. Uma possibilidade para se atingir este objetivo consiste em se estabelecer uma estatística que possibilite ordenar os "genes" segundo suas evidências de expressão diferencial, da mais forte para a mais fraca evidência, e escolher para esta estatística um valor crítico (pré-estabelecido ou adotado empiricamente) que permitirá realizar a distinção entre genes considerados significativos e os não significativos. Além disso, vale frisar que frente à expressiva quantidade de "genes" presentes nos estudos de Microarrays, a ordenação dos mesmos é de suma importância, deixando a critério do pesquisador a decisão por selecionar o conjunto inicial de "genes" DE a serem acompanhados em estudos futuros.

Outro fator importante quando abordada a questão de genes diferencialmente expressos diz respeito à extração de informações Biológicas dos dados resultantes do experimento de Microarrays, a qual nem sempre é simples e requer o uso de métodos estatísticos apropriados. A metodologia estatística paramétrica mais simples para detectar genes DE é a conhecida estatística $t$-student, a qual é utilizada para comparação de duas condições experimentais quando há réplicas suficientes no experimento. Já, no contexto em que há o interesse em se comparar mais de duas condições, os modelos de ANOVA têm sido amplamente utilizados. Em ambas as situações (duas ou mais de duas condições experimentais) as metodologias que usam correção nas estatísticas para os múltiplos testes envolvidos são preferidos pois controlam a taxa de resultados falsopositivos. 


\subsection{Metodologia empírica Fold-change}

O mais simples método empírico utilizado para identificar genes DE é avaliar o logaritmo da razão dos valores de expressão gênica entre duas condições (ou a média dos logaritmos das razões dos valores de expressão gênica, no caso em que há réplicas no experimento) e considerar como DE aqueles genes no qual o logaritmo da razão (ou a média dos logaritmos das razões) exceder um valor de corte arbitrário pré-estabelecido ou determinado empiricamente, $R_{c}$. Para formalizar esta metodologia, considere que para dois arrays $j$ e $j^{\prime}$ a serem comparados se tem,

$$
M_{g}=\log _{2}\left(\frac{y_{A_{g j}}}{y_{B g j^{\prime}}}\right)
$$

onde as condições $A$ e $B$ foram avaliadas, respectivamente, nos arrays $j$ e $j$ '.

Por outro lado, considerando que $n_{a}$ e $n_{b}$ arrays tenham sido avaliados, respectivamente, sob as condições $A$ e $B$ se tem,

$$
\bar{M}_{g}=\frac{\sum_{j=1}^{n_{a}} \log _{2}\left(y_{A g j}\right)}{n_{a}}-\frac{\sum_{j=1}^{n_{b}} \log _{2}\left(y_{B j^{\prime}}\right)}{n_{b}}
$$

onde $\bar{M}_{g}$ representa a diferença entre as expressões gênicas médias do $g$ - ésimo gene nas condições $A$ e $B, g=1, \ldots, G$.

O critério para designação do $g$ - ésimo gene como DE é estabelecido sobre a simples comparação,

$$
\left|\bar{M}_{g}\right| \geq R_{c}
$$

Essa medida empírica $\bar{M}_{g}$ denominada por fold-change, muito popular por decorrência de sua simplicidade, foi a primeira a ser utilizada com o propósito de se encontrar genes DE em análises de Microarrays, embora, atualmente, seja um consenso de que o uso individual desta medida para se testar expressão diferencial seja apenas descritivo, (Allison et al., 2006).

Uma limitação da medida fold-change está no fato da mesma não considerar as diferentes variabilidades que possam estar presentes nos valores de expressão gênica de 
todos os genes avaliados no estudo, implicando na suposição de homogeneidade para estes valores (Speed, 2003, Allison et al., 2006). Por conseqüência, genes com maiores variâncias (em geral genes com baixos valores de expressão gênica) podem fornecer altos valores de fold-change e serem incorretamente classificados como DE. Tal efeito pode ser diagnosticado no gráfico MA quando, por exemplo, tendências na forma de funil são encontradas no padrão de dispersão dos pontos (genes).

\subsection{Teste $t$ e testes $t$ modificados}

Nos experimentos de Microarrays, quando se tem por interesse comparar expressões gênicas entre duas condições experimentais com o propósito de identificar genes DE, uma metodologia paramétrica simples para este fim é a utilização do teste $t$ student específico para cada gene. Uma vez que experimentos com réplicas possibilitam a estimação do erro-padrão da resposta de expressão gênica associada a cada gene, $S E_{g}$, a partir dos valores do logaritmo das razões entre expressões gênicas das duas condições, a estatística $t$ para o $g$ - ésimo gene pode ser expresso por,

$$
t_{g}=\frac{\bar{M}_{g}}{S E_{g}}
$$

onde $S E_{g}=s_{g} / \sqrt{\frac{1}{n_{a}}+\frac{1}{n_{b}}}$, com $s_{g}$ o desvio padrão comum.

Desta forma, a decisão para identificação do $g$ - ésimo gene como DE deve ser realizada com base no valor nível descritivo ( $p$-valor) para $t_{g}$ (3.3.1), na distribuição desta estatística, supostamente a distribuição t com $n_{a}+n_{b}-2$ graus de liberdade. Vale ressaltar que, no contexto em que as condições experimentais $A$ e $B$ são avaliadas no mesmo array, como é o caso dos delineamentos com Microarrays de cDNA, é mais apropriado considerar a estatística $t$ para amostras pareadas (Neter et al., 2004). Por outro lado, na situação oposta, quando as condições experimentais $A$ e $B$ são avaliadas em diferentes arrays, como é o caso dos delineamentos com Microarrays de Oligonucleotídeos, se deve adotar a estatística $t$ para amostras independentes como em (3.3.1). 
Comparada à metodologia de fold-change, o teste $t$ proporciona a vantagem de se considerar a variabilidade específica de cada gene no processo de classificação deste como significativamente DE ou não. Por utilizar somente as informações de um único gene a cada estatística calculada, $t_{g}$, o teste $t$, aparentemente, não é afetado por uma provável heterogeneidade de variâncias entre genes, contudo, em virtude da pequena quantidade de réplicas usualmente presentes nos experimentos de Microarrays, é possível que o poder associado ao teste $t$ seja baixo. Em adição, outro problema inerente à aplicação do teste $t$ a Microarrays ocorrer quando a variabilidade específica do gene é muito pequena, resultando em valores altos para a estatística $\left|t_{g}\right|$, mesmo naquelas situações onde o valor de $\left|\bar{M}_{g}\right|$ esteja muito próximo de zero, induzindo à classificação estatística de genes como DE quando estes não são considerados DE pelo geneticista.

Ambas as estratégias de análise estatística apresentadas anteriormente têm sido utilizadas na identificação de genes DE: a metodologia de fold-change - implicitamente assumindo homogeneidade de variâncias entre os genes presentes no estudo, e o teste $t$ permitindo explicitamente a incorporação da variância específica de cada gene e o cálculo de um nível de significância. Todavia, nenhuma delas é apropriada quando o número de réplicas é pequeno e se tendo em vista os inúmeros testes realizados simultaneamente em experimentos de Microarrays (Speed, 2003).

$\mathrm{Na}$ tentativa de contornar estas limitações, modificações do teste $t$ padrão foram apresentadas, as denominadas estatísticas $t$ modificadas, onde, basicamente, são sugeridas formas alternativas de representação do erro-padrão presente no denominador da estatística $t$.

A proposta denominada por teste $t$ global (Cui \& Churchill, 2003), sugere a substituição do $S E_{g}$ (3.3.1) por um erro-padrão calculado a partir da utilização dos valores de expressão gênica de todos os genes em avaliação, $S E$, assumindo, neste caso, homogeneidade de variância entre genes. Sob esta suposição, os resultados construídos através do teste $t$ global são os mesmos produzidos pela metodologia fold-change, pelo simples fato de ambas as metodologias não considerarem a variabilidade individual de cada gene e fornecerem como resultado a mesma ordenação, segundo suas evidências de expressão diferencial, dos genes em estudo. Desta forma, na situação em que não se tem homogeneidade de variância para todos os genes, o teste $t$ global está exposto aos 
mesmos problemas descritos anteriormente para a metodologia de fold-change, (Cui e Churchill, 2003).

O teste $t$ global para o $g$ - ésimo gene pode ser expresso por,

$$
t_{g}=\frac{\bar{M}_{g}}{S E}
$$

com $S E=s / \sqrt{\frac{1}{G\left(n_{A}+n_{B}\right)}}, s$ representando o desvio-padrão amostral considerando todos os $G$ genes em estudo.

É importante observar que a estatística $t_{g}$ em (3.3.2) definida no teste $t$ global não terá a mesma distribuição da estatística $t_{g}$ (3.3.1) definida no teste $t$ específico para cada gene, sendo necessária a utilização de métodos de permutação para obtenção de uma distribuição aproximada para a mesma (Good, 1994; Dudoit et al., 2000; Ge et al., 2003).

Outra proposta de modificação da estatística $t$ do teste $t$ consiste da inclusão de uma constante $c$ no denominador da mesma. Diversas propostas para quantificação da constante $c$ estão presentes na literatura. Smyth et al. (2003) propõe para $c$ o valor referente ao percentil $90 \%$ da distribuição dos desvios-padrão calculados para todos os genes envolvidos no estudo. Este procedimento é bastante simples, uma vez que basta calcular o desvio-padrão para cada gene e, após ordenar estes valores, atribuir à constante c o valor referente ao percentil 90\% desta distribuição. Por outro lado, Tusher et al. (2001) sugerem um procedimento para determinação da constante $c$ baseado em simulações. De forma análoga a Smyth et al. (2003), inicialmente, são realizados os cálculos dos desvios-padrão para todos os genes. Em seguida, com os valores dos percentis da distribuição dos desvios-padrão, $p_{1}, p_{2}, \ldots, p_{100}$, para cada gene presente no estudo são simuladas 100 estatísticas penalizadas a partir da substituição da constante $c$ pelo percentil $p_{i}$. Em seguida, utilizando os valores das 100 estatísticas $t$ modificadas, para cada gene é calculado um coeficiente de variação - CV associado a cada percentil (contabilizando um total de $100 \mathrm{CV}$ 's). Por fim, à constante $c$ é atribuído o valor do percentil associado ao menor $\mathrm{CV}$.

O teste $t$ penalizado por uma constate para o $g$ - ésimo gene pode ser expresso por, 


$$
t_{g}=\frac{\bar{M}_{g}}{c+S E_{g}}
$$

com $S E_{g}=s_{g} / \sqrt{\frac{1}{n_{A}}+\frac{1}{n_{B}}}, s_{g}$ representando o desvio-padrão amostral do $g$ - ésimo gene e $c$ representando a constante de penalização.

De maneira análoga ao teste $t$ global, a distribuição da estatística $t_{g}$ penalizada em (3.3.3) também deve ser obtida por metodologias de permutação.

Sob a abordagem Bayesiana, o denominador do teste $t$ regularizado proposto por Baldi \& Long (2001) fornece mais uma estatística $t$ modificada para identificação de genes diferencialmente expressos. O teste $t$ regularizado para o $g$-ésimo gene considera uma média ponderada entre a variância específica deste gene e a variância global para o cálculo da estatística tregularizada, a qual pode ser expressa por,

$$
t_{g}=\frac{\bar{M}_{g}}{\sqrt{\frac{v_{0} S E^{2}+\left(n_{A}+n_{B}-1\right) S E_{g}^{2}}{v_{0}+n_{A}+n_{B}-2}}}
$$

com $v_{0}$ representando o parâmetro que determina a relativa contribuição do gene específico na variância global (Baldi \& Long, 2001).

A construção teórica do denominador da estatística $t$ regularizada em (3.3.4) provém de resultados construídos sob a abordagem Bayesiana. Nesse paradigma, a escolha de distribuições a priori para os parâmetros da distribuição amostral faz parte do processo de modelagem, as quais combinadas com a distribuição amostral, através do teorema de Bayes, resultam na denominada distribuição a posteriori, sob a qual se realiza as inferências de interesse. Detalhes sobre especificações das distribuições a priori e estimação dos parâmetros da posteriori, os quais são utilizados no denominador da estatística $t_{g}$ estão presentes em Baldi \& Long (2001).

As metodologias padrão para o cálculo do nível descritivo dessas estatísticas $t$ modificadas $(p-$ valor $)$ se baseiam em tabelas de referência para a distribuição da estatística adotada ou análises de permutação, sendo que em ambos os casos algumas vantagens e desvantagens podem ser destacadas. Por exemplo, ao se utilizar os valores tabulados para uma estatística com distribuição conhecida, como é o caso das 
estatísticas $t$-student, frequientemente se faz necessária a suposição de que os erros do modelo adotado para os dados sejam normalmente distribuídos. Por outro lado, as análises de permutação não exigem tal suposição, contudo, para aplicação destas se deve assegurar uma quantidade mínima de réplicas para cada condição presente no experimento (Cui \& Churchill, 2003).

Uma vez obtido o $p$-valor associado a uma estatística que avalia a hipótese nula de interesse, o pesquisador deve decidir pela rejeição ou não da mesma. Neste memento, caso a decisão tomada pelo pesquisador seja incorreta, esta resultará em um dentre os dois tipos de erro possíveis, a saber: Erro Tipo I (falso-positivo) ou Erro Tipo II (falso-negativo).

Em experimentos de Microarrays, a ocorrência dos resultados falso-positivos é conseqüência da decisão de se rejeitar a hipótese nula para genes que de fato não são DE sobre as diferentes condições experimentais avaliadas e a ocorrência dos resultados falso-negativos é conseqüência de não se optar pela rejeição da hipótese nula para genes que de fato são DE sobre as diferentes condições experimentais avaliadas. Tipicamente, os resultados falso-positivos podem ocorrer, principalmente, em situações de múltiplos testes onde não são aplicadas metodologias de correção aos $p$-valores. Já, os resultados falso-negativos podem ocorrer quando o denominador da estatística de teste possuir valor elevado por decorrência da pequena quantidade de réplicas (dificuldade em se estimar o verdadeiro erro-padrão) e, também, por se ter inúmeras fontes de variação sistemática neste tipo de experimento.

Frente às centenas de milhares de testes de hipóteses que são realizados em experimentos de Microarrays, um para cada gene presente no estudo, se adotado um valor para o nível de significância como aqueles comumente utilizados em outros tipos de análise estatística (por exemplo, $\alpha=0,01$ ou $\alpha=0,05$ ), uma quantidade substancial de resultados falso-positivos pode se acumular, ocasionando o denominado "Problema de Múltiplos Testes", (Cui \& Churchill, 2003; Dudoit et al., 2003; Alison, 2006; Dudoit $\&$ van der Laan, 2008).

Para se ter idéia do impacto do problema de múltiplos testes em Microarrays, suponha um experimento contendo G genes para os quais serão realizados testes de hipóteses com o objetivo de se averiguar expressão diferencial. Adotando um nível de 
significância $\alpha$ para cada teste, se pode mostrar que o nível de significância global para a família de testes, $\alpha^{*}$, considerando os $G$ testes independentes, será dado por,

$$
\alpha^{*}=1-(1-\alpha)^{G} \text {. }
$$

$\mathrm{O}$ valor de $\alpha^{*}$ representa a probabilidade de se cometer o Erro Tipo I durante a realização do conjunto de testes, a qual depende do número de genes a serem testados e do nível de significância adotado para cada teste. A Figura 8 ilustra o comportamento de $\alpha^{*}$ para diferentes valores de $\alpha$ e diferentes números de genes (quantidade de testes a serem realizados), refletindo o problema de múltiplos testes (Dudoit et al., 2003).

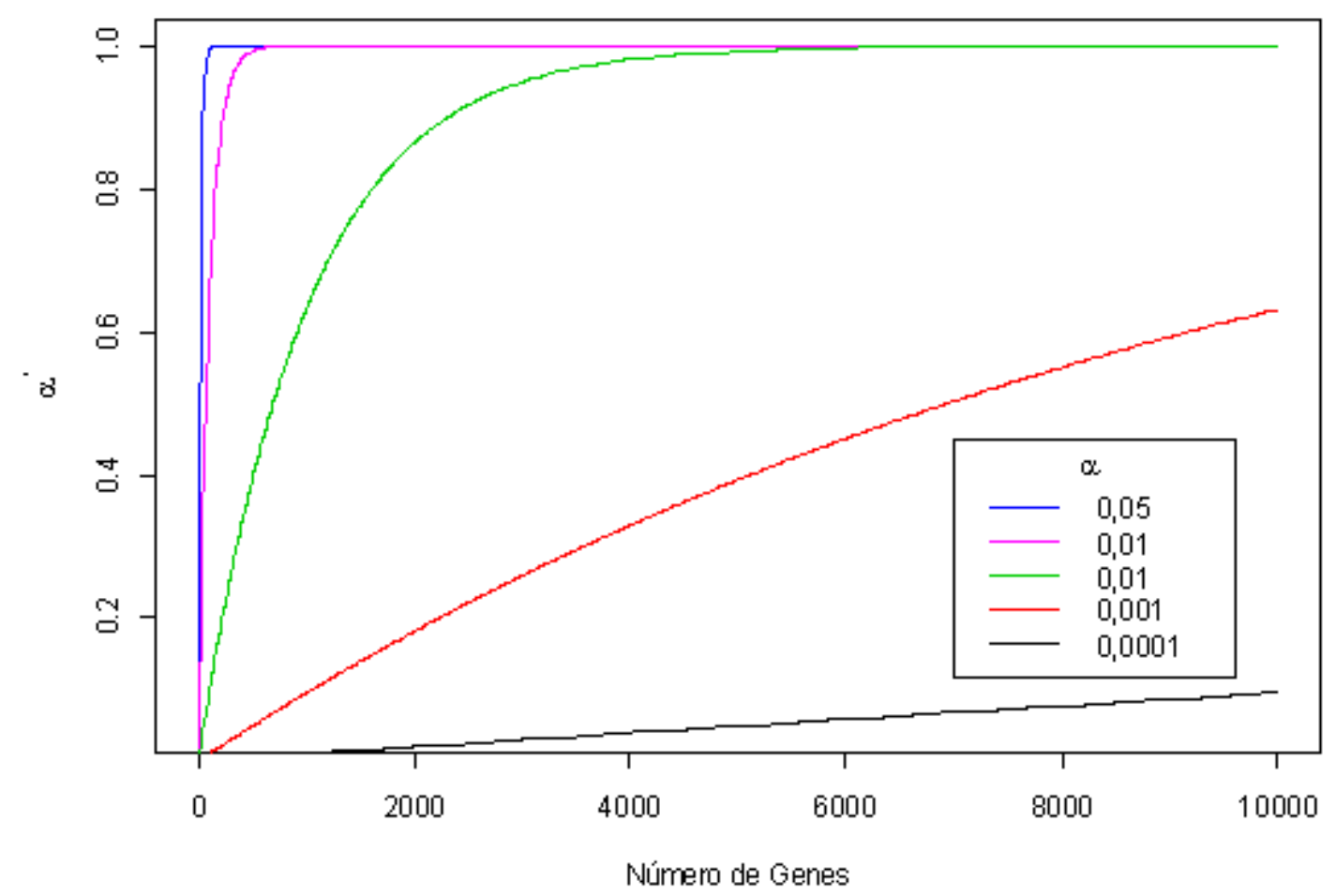

Figura 8. Ilustração do comportamento do Erro Tipo I para diferentes valores de $\alpha$ e diferentes quantidades de genes.

Observe que para valores usuais de $\alpha(\alpha=0,05 ; \alpha=0,01 ; \alpha=0,001)$, mesmo quando a expressão diferencial de uma pequena quantidade de genes está sendo testada simultaneamente, a probabilidade de se cometer o Erro Tipo I já pode ser considerada muito elevada, resultando na ocorrência dos resultados falso-positivos. 
Todavia, existem metodologias que possibilitam o controle de ocorrências dos resultados falso-positivos a partir da imposição de critérios restritivos para $\alpha$. A seguir são apresentadas duas metodologias muito usuais: o controle por FWER (Family-Wise Error Rate) e o controle por FDR (False Discovery Rate).

A abordagem mais rigorosa para o problema de múltiplos testes é o controle FWER, o qual controla (limita) a probabilidade de se acumular um ou mais resultados falso-positivos através do aumento individual de rigorosidade para cada teste, ou seja, em cada teste a probabilidade de se cometer o Erro do Tipo I é drasticamente diminuída. Em experimentos de Microarrays, a construção de uma lista de genes DE que satisfaça os critérios do controle FWER gera altíssima confiança de que nela não haverá genes falso-positivos (Cui \& Churchill, 2003). Em contrapartida, se pode argumentar que a aplicação de uma abordagem tão rigorosa como o controle FWER seja desnecessária no contexto de Microarrays, pois a seleção de uma pequena parcela de genes classificados incorretamente como DE não causaria sérios problemas se a maioria dos genes significativamente DE tenha sido corretamente selecionada (Smith, 2003). O mais simples controle FWER é a denominada correção de Bonferroni, onde o nível de significância $\alpha$ de um particular teste é dividido pelo número de testes, resultando em um teste extremamente conservador à rejeição da hipótese nula. Outros procedimentos FWER incluem a correção baseada em permutações nomeadas por one-step (Kerr et al., 2003) e o ajuste step-down (Westfall \& Young, 1993). A aplicação de controles tão restritos como o FWER pode substancialmente diminuir o poder do teste quando o número de testes é elevado, como é o caso dos experimentos de Microarrays. Deste modo emerge a necessidade de se procurar processos alternativos de controle.

Enquanto para alguns estudos o controle FWER como proposta de solução para o problema de múltiplos testes se faz útil e necessário, o problema de múltiplos testes em Microarrays usualmente não requer uma proteção tão rigorosa como a imposta por este controle, uma vez que a perda de poder associado aos testes pode não ser justificável. Sendo assim, como alternativa ao rigoroso controle FWER, Benjamini \& Hochberg (1995) propuseram a metodologia denominada por False Discovery Rate FDR com o propósito de controlar a proporção de genes classificados incorretamente como DE (resultados falso-positivos). Diferentemente do nível de significância, o qual é pré-estabelecido antes de se iniciar as análises, o FDR é uma medida de confiança calculada após a realização dos múltiplos testes de hipóteses, a qual é calculada a partir 
das informações presentes nos dados. Em experimentos de Microarrays, ao se construir uma lista de genes DE que satisfaça os critérios do controle FDR se pode esperar uma proporção conhecida de resultados falso-positivos, além disso, por ser o FDR menos restritivo, permitindo a ocorrência desta proporção de erro, quando comparado ao controle FWER, o mesmo permite atingir maiores poderes associados aos testes. De modo a definir o FDR considere a Tabela 1.

Tabela 1. Possibilidades de resultados de $m$ testes de hipótese.

\begin{tabular}{lcccc}
\hline & \multicolumn{3}{c}{ Hipótese nula } \\
\hline & Falsa & & Verdadeira & \\
\cline { 2 - 2 } Não rejeitada & $T$ & & $W$ \\
Rejeitada & $S$ & & $R$ \\
& $m_{1}$ & & $m_{0}$ & $m$ \\
\hline
\end{tabular}

Na Tabela $1 \mathrm{~m}$ representa o número de hipóteses testadas, $W$ representa o número de hipóteses nulas não rejeitadas, $R$ o número de hipóteses nulas rejeitadas, $m_{1}$ representa o número de hipóteses nulas falsas, $m_{0}$ representa o número de hipóteses nulas verdadeiras, $U$ representa a soma das decisões corretas por não rejeitar as hipóteses nulas verdadeiras, $S$ representa a soma das decisões corretas por rejeitar as hipóteses nulas falsas, $T$ a soma das decisões incorretas por não rejeitar as hipóteses nulas falsas (erro falso-negativo) e $V$ representa a soma das decisões incorretas por rejeitar as hipóteses nulas verdadeiras (erro falso-positivo).

Conforme as definições acima, considerando uma família de $m$ hipóteses nulas testadas simultaneamente, o FDR é definido como o valor esperado da proporção de hipóteses nulas incorretamente rejeitadas, ou seja,

$$
F D R=\left\{\begin{array}{cc}
E\left[\frac{V}{R}\right], & R>0 \\
0, & R=0 .
\end{array}\right.
$$

Um procedimento bastante utilizado para se calcular do FDR é o Linear Step-Up proposto por Benjamini \& Hochberg (1995). Este procedimento faz uso dos $p-$ valores ordenados $p_{(1)} \leq \cdots \leq p_{(m)}$ resultantes das $m$ hipóteses $H_{(1)}, \ldots, H_{(m)}$ testadas simultaneamente. Para se atingir um nível de FDR desejado $\alpha$, comparações entre os 
$p$-valores ordenados, $p_{(k)}, k=1, \ldots, m$, e o valor crítico $\alpha \times k / m$ são realizadas. Desta forma, ao se calcular

$$
\hat{k}=\arg \max _{1 \leq k \leq m}\left\{k: p_{(k)}<\alpha \times k / m\right\}
$$

e ao se rejeitar as hipóteses nulas correspondentes a $p_{(1)}, \ldots, p_{(\hat{k})}$ se obtém um $F D R=$ $\alpha \times m_{0} / m \leq \alpha$, quando os $m$ testes de hipóteses são independentes ou positivamente dependentes (Benjamini \& Hochberg (1995); Benjamini et al. (2005)).

Além do procedimento Linear Step-Up, uma alternativa de aplicação do controle FDR é o denominado Adaptive Procedures (Benjamini et al., 2001). Em linhas gerais, o Adaptive Procedures é um procedimento realizado em dois estágios. No primeiro estágio $r_{1}$ hipóteses nulas são rejeitadas através do procedimento Linear Step-Up. No segundo estágio, os $p$-valores relacionados às $r_{1}$ hipóteses rejeitadas no primeiro estágio são novamente corrigidos através da aplicação do procedimento Linear Step-Up, embora um novo valor crítico dado por $\alpha^{*}=\alpha \frac{m}{\left(m-r_{1}\right)(1+\alpha)}$ seja utilizado como critério de rejeição das hipóteses nulas.

Outras metodologias de procedimentos de controle FDR como, por exemplo, o Resampling FDR Adjustments proposta por Yekutieli \& Benjamini (1999), o False Discovery Rate Controlling Procedures proposta por Reiner et al. (2003), dentre outros, estão disponíveis na literatura. A utilização destes procedimentos em análises de dados de Microarrays pode ser realizada, por exemplo, a partir do software $\mathrm{R}$ através de pacotes como, por exemplo, o MAANOVA (Wu et al., 2008) ou o FDR-AME (FDR Adjustments of Microarray Experiments) (Benjamini et al., 2005).

Contudo, para ambos os controles FWER e FDR aqui expostos já existem outras metodologias mais eficientes com propósitos semelhantes. Por exemplo, uma variação do FDR indiscutivelmente mais adequada é denominada por positive False Discovery Rate - pFDR proposta por Storey (2002), a qual multiplica o valor do controle FDR por um fator $\pi_{0}$ que representa a proporção estimada dos genes classificados como não DE entre todos os genes (Cui \& Churchill, 2003). Ainda para o contexto de Microarrays, Alisson (2006) descreve que outras Metodologias baseadas em Mistura de Modelos que também podem ser introduzidas com o propósito de se estimar o FDR para genes classificados como DE. Este autor introduziu um modelo de misturas que considera os 
genes como sendo compostos por duas ou mais populações, uma representando os genes $\mathrm{DE}$ e a(s) outra(s) representando os genes não DE. Ele também aponta que a diferença entre estes modelos mistos e a metodologia FDR originalmente proposto por Benjamini \& Hochberg (1995) está no fato da primeira estimar o FDR, enquanto a segunda controla (limita) o FDR a um determinado nível (proporção), assegurando que a metodologia a base de modelos mistos tendem a ser muito mais poderosas. Atualmente, diversas metodologias a base de modelos mistos foram propostas por pesquisadores incluindo, por exemplo, Datta \& Datta (2005), havendo um consenso de que os procedimentos de estimação do FDR são preferidos aos controles FWER e FDR.

\subsection{Mais do que duas condições experimentais}

Em estudos de Microarrays nos quais se tem por interesse comparar os valores de expressão gênica provenientes de mais de duas condições experimentais, os testes $t$ anteriormente apresentados são ineficientes por não utilizarem todas as informações disponíveis nos dados, sendo, neste contexto, os métodos de Análise de Variância (ANOVA) uma alternativa mais apropriada para análise dos dados (Churchill, 2004).

Segundo Churchill (2004), a ANOVA fornece uma metodologia de análise de dados que é motivada pelas considerações do delineamento experimental, as quais devem ser determinadas pelas questões científicas sob investigação e estarem alinhadas às restrições práticas do experimento. Em linhas gerais, a ANOVA é empregada com a finalidade de se particionar a variabilidade total presente em uma medida de interesse (variável resposta) em componentes de variância (fatores/variáveis exploratórias) que estejam associadas às diversas fontes de variação presentes no estudo.

Em particular para os experimentos de Microarrays, um dentre os propósitos da ANOVA é particionar a variabilidade total presente nos valores de expressão gênica em componentes de variância associados às diferentes condições experimentais (as quais, geralmente, são utilizadas para se detectar genes diferencialmente expressos) e aquelas associadas às especificações e restrições experimentais (como, por exemplo, o tipo de plataforma utilizada, o tipo de delineamento experimental adotado, etc.). Experimentos com múltiplas componentes de variância (fatores), como é o caso dos experimentos de 
Microarrays, nos quais os efeitos de diversas fontes de variação são simultaneamente avaliadas, freqüentemente, são mais eficientes e mais compreensíveis do que um conjunto de experimentos com um único fator. De fato, o verdadeiro potencial da ANOVA é mais facilmente notado em experimentos contendo múltiplos fatores (Churchill, 2004).

Os modelos de ANOVA para Microarrays fornecem ainda uma abordagem integrada que permite a normalização (paramétrica) dos dados, a estimação dos valores de expressão gênica e a possibilidade de elaboração de testes para detecção de genes diferencialmente expressos (Kerr et al., 2000). Tal integração se dá através da especificação do modelo, a qual, em geral, considera como variável resposta o logaritmo do valor de expressão gênica expressa em função de uma soma de termos representando a contribuição (efeito) dos diversos fatores relacionados ao delineamento adotado (como, por exemplo, efeitos dos arrays ou das diferentes colorações, esquema experimental utilizado na hibridização dos arrays: blocos, quadrado latino, fatorial, etc.) e às condições experimentais (diferentes condições biológicas ou tratamentos).

A quantificação da variabilidade que provém de múltiplas fontes de variação é essencial para se interpretar apropriadamente os dados de Microarrays (Haan et al., 2007). Uma importante distinção relacionada aos termos que compõem os modelos de ANOVA deve ser considerada ao se adotar o modelo na tentativa de, por exemplo, encontrar genes diferencialmente expressos. Nos modelos de ANOVA com efeito fixo, adequados para muitos delineamentos experimentais, a única fonte de variação aleatória considerada é representada pelo termo associado ao erro do modelo, estando os demais termos associados a efeitos fixos ${ }^{9}$. Por outro lado, quando há a necessidade de se considerar múltiplas fontes de variação aleatória, uma alternativa é a utilização dos modelos de ANOVA de efeito misto que são compostos por termos de efeito fixo e termos de aleatório (Churchill, 2004).

Atualmente, muitas são as aplicações em Microarrays envolvendo modelos de ANOVA na tentativa de se detectar genes diferencialmente expressos (Juenger et al., 2006). Embora existam diversas propostas de modelos, a seguir, para exemplificar uma aplicação da ANOVA à Microarrays, é apresentado um modelo de ANOVA de efeitos

\footnotetext{
${ }^{9}$ Segundo (Churchill, 2004), uma maneira para se determinar se o termo deve ser considerado fixo ou aleatório é imaginar uma repetição do experimento. Se o efeito pudesse ser o mesmo na repetição do experimento, o termo é fixo.
} 
fixos incorporando efeitos de array, coloração das amostras, condições experimentais, gene e algumas interações.

\section{Modelo}

Considerando $y_{j l i g}$ o valor de expressão gênica mensurada no $j$ - ésimo array, sob a $i$ - ésima condição experimental e o $g$ - ésimo gene, um possível modelo de efeitos fixos adotado para descrever as múltiplas fontes de variação em um experimento de Microarrays pode ser expresso por,

$$
\log \left(y_{j l i g}\right)=\mu+A_{j}+V_{i}+G_{g}+(A G)_{j g}+(V G)_{i g}+\epsilon_{j l i g}
$$

com $\mu$ representando a média global do valor de expressão gênica, $A_{j}$ representando o efeito do $j$-ésimo array, $V_{i}$ representando o efeito da $i$-ésima condição experimental, $G_{g}$ representando o efeito do $g$ - ésimo gene, $(A G)_{j g}$ representando interação entre o $j$ - ésimo array e o $g$ - ésimo gene (efeito de um particular spot no array $j),(V G)_{i g}$ representando a interação entre a $i$ - ésima condição experimental e o $g$ - ésimo gene, $\epsilon_{j l i g}$ o termo representando os erros do modelo, os quais, são supostos ser independentes e identicamente distribuídos com média zero e variância $\sigma^{2}$.

No modelo (3.4.1), o efeito $A_{j}$ representa as diferenças entre as médias gerais dos arrays (calculada sobre todos os genes), provindos, por exemplo, do processo de hibridização ou pela utilização de arrays com diferentes padrões de qualidade. Já o efeito $V_{i}$ explica as diferenças gerais entre condições experimentais decorrentes, por exemplo, de diferentes concentrações de mRNA presentes nas amostras das condições experimentais avaliadas. O termo $G_{g}$ contabiliza o efeito médio individual de cada gene no array e o termo $(A G)_{j g}$ representa o efeito médio do gene $g$ no array $j$ (efeito de spot), decorrente da impossibilidade de se controlar completamente a quantidade e concentração de cDNA fixado nos spots de cada array. Em geral, apesar dos efeitos anteriormente citados representarem fontes de variabilidade presentes em Microarrays, geralmente, estes não são de maior interesse para o pesquisador. O efeito que de fato interessa está representado pelo termo $(V G)_{i g}$ e se refere à interação entre condição experimental e gene, o qual reflete desvios da média global atribuídos à específica combinação entre a $i$ - ésima condição experimental e o $g$ - ésimo gene. 
Uma particularidade do modelo especificado em (3.4.1), é o de incorporar o efeito de todos os genes simultaneamente no modelo, adicionando assim muitos parâmetros. A prática mais comum consiste em ajustar um modelo ANOVA para cada gene separadamente. Vale ressaltar que os modelos de ANOVA são bastante flexíveis e possibilitam a incorporação de efeitos relacionados a outras fontes de variação (possibilitando de certo modo a comparação entre a adequação de diferentes modelos para resolução do problema). Outra proposta interessante para utilização dos modelos de ANOVA em experimentos de Microarrays é apresentada em Wolfinger et al. (2001), os quais propõem uma abordagem de análise baseada na utilização de dois modelos mistos de ANOVA, sendo o primeiro modelo utilizado como proposta para normalização dos dados e o segundo modelo com o propósito de se encontrar genes diferencialmente expressos.

Outra grande vantagem da ANOVA é a possibilidade de se testar a significância individual de cada termo incorporado ao modelo, a qual é calculada a partir de uma estatística $F$ clássica ou modificada. Em linhas gerais, o teste $F$ clássico da ANOVA proporciona a comparação de mais de duas condições experimentais através de comparações entre as variabilidades presentes dentro de cada condição experimental e entre as condições experimentais (ver Fisher (1925); Montgomery (2005)). De modo semelhante ao teste $t$ clássico, diversas propostas de modificação para a estatística $F$ clássica estão disponíveis na literatura, incluindo as estatísticas $F_{1}, F_{2}$ e $F_{3}$ apresentadas por Cui \& Churchill (2003) e a estatística $F_{S}$ proposta por Cui et al. (2005), brevemente discutidas a seguir.

Como resultado, a elaboração de testes estatísticos para cada termo do modelo resultará em uma listagem contendo os níveis descritivos ( $p$-valor) para cada estatística $F$ associada a um termo, as quais podem ser obtidas com o auxílio da tabela da distribuição $F$ clássica ou a partir de análises de permutação (Draghici, 2003).

\section{Teste $F$}

Apesar de neste trabalho terem sido utilizados modelos de ANOVA de efeito fixo, aproveitando as discussões dos modelos de ANOVA de efeitos mistos apresentada 
por Wu et al (2008), os quais pertencem a uma classe mais ampla de modelos, quando comparados aos modelos de efeito fixo, a obtenção das estatísticas $F$ serão apresentadas, inicialmente, para o contexto de modelos de ANOVA de efeito aleatório e, posteriormente, particularizadas para os modelos de ANOVA de efeito fixo.

Segundo Wu et al (2008), matematicamente um modelo linear de efeito misto de ANOVA pode ser expresso, sem perda de generalidade, da seguinte forma,

$$
y=X \beta+Z u+\varepsilon
$$

onde $\beta$ e $u$ representam, respectivamente, os vetores dos parâmetros de efeito fixo e aleatório e $X$ e $Z$ representam as matrizes do delineamento.

Note que o modelo de efeito fixo é um caso particular do modelo de efeito misto quando não são considerados os termos aleatórios $Z u$. Sob o modelo (3.4.2) se supõe que $u$ e $\varepsilon$ são normalmente distribuídos com $E\left[\begin{array}{l}u \\ \varepsilon\end{array}\right]=\left[\begin{array}{l}0 \\ 0\end{array}\right]$ e $\operatorname{Var}\left[\begin{array}{l}u \\ \varepsilon\end{array}\right]=\left[\begin{array}{ll}G & 0 \\ 0 & R\end{array}\right]$, onde $G$ e $R$ são componentes de variância desconhecidas (estimadas, por exemplo, pelo método de Máxima Verossimilhança Restrita (ver Searle et al., 1992)). Usando as estimativas de $G$ e $R$, a matriz de variância-covariância de $\hat{\beta}^{10}$ e $\hat{u}^{11}$ pode ser expressa por,

$$
\hat{C}=\left[\begin{array}{cc}
X^{\prime} \hat{R}^{-1} X & X^{\prime} \hat{R}^{-1} Z \\
Z^{\prime} \hat{R}^{-1} X & Z^{\prime} \hat{R}^{-1} Z+\widehat{G}^{-1}
\end{array}\right]^{-}
$$

Uma vez obtida a matriz $\hat{C}$ os testes estatísticos podem ser elaborados. Para uma dada hipótese, digamos,

$$
H: L\left[\begin{array}{l}
\beta \\
u
\end{array}\right]=0
$$

a estatística F será dada por,

$$
F=\frac{\left[\begin{array}{l}
\hat{\beta} \\
u
\end{array}\right] L^{\prime}\left(L \hat{C} L^{\prime}\right) L\left[\begin{array}{l}
\hat{\beta} \\
u
\end{array}\right]}{q}
$$

onde $q$ é o rank da matriz $L$.

\footnotetext{
${ }^{10}$ BLUE (Best Linear Unbiased Estimator) - melhor estimador linear não viesado.

${ }^{11}$ BLUP (Best Linear Unbiased Predictor) - melhor preditor linear não viesado.
} 
Note que para o modelo de ANOVA de efeito fixo a estatística $F$ se resume a,

$$
F=\frac{(L \hat{\beta})^{\prime}\left(L\left(X^{\prime} X\right)^{-} L^{\prime}\right)^{-1} L \hat{\beta}}{q \sigma_{\varepsilon}^{2}}
$$

onde $\sigma_{\varepsilon}^{2}$ representa a variância do erro.

No contexto de Microarrays, diferentes estatísticas $F_{1}, F_{2}, F_{3}$ e $F_{s}$ são calculadas para estudar os genes DE sob as condições experimentais. Em resumo, para o cálculo da estatística $F_{1}$ se assume heterogeneidade entre as variâncias dos genes, sendo considerada para o cálculo de $\hat{C}$ apenas a variação específica do gene testado. Em contra partida, para o cálculo da estatística $F_{3}$ se assume homogeneidade entre as variâncias dos genes, sendo a matriz $\hat{C}$ calculada a partir de uma variância global (variância média de todos os genes). Já, a estatística $F_{2}$ faz uma ponderação entre a variância específica do gene testado e a variância global para o cálculo da matriz $\hat{C}$. Por fim, a estatística $F_{S}$ é calculada com base no estimador de James-Stein (Lindley, 1962). A estatística $F_{1}$ representa a estatística $F$ clássica e a significância associada à mesma pode ser obtida a partir da tabela da distribuição $F$ clássica, entretanto, as estatísticas $F_{2}, F_{3}$ e $F_{S}$ não seguem a distribuição $F$ clássica e sendo suas significâncias estabelecidas por análise de permutação.

Novamente, vale enfatizar que dada a necessidade de se elaborar centenas de milhares de testes, um para cada gene, também para a situação em que se compara mais de duas condições experimentais, naturalmente, o problema de múltiplos testes está presente. Sendo assim, para controlar a ocorrência dos erros tipo I (falso-positivo) e II (falso-negativo), os valores de significância associados a cada um dos termos do modelo na ANOVA devem ser corrigidos, por exemplo, a partir das metodologias de controle FWER e FDR discutidas anteriormente.

Neste trabalho, se optou pela utilização do software R e o pacote R/maanova (Microarray ANalysis Of VAriance ${ }^{12}$ ), pois no mesmo estão contidas ferramentas que possibilitam, dentre outras coisas, a visualização e transformação dos dados; a geração de interfaces gráficas como, por exemplo, os gráficos vulcões; o ajuste de modelos de ANOVA de efeito fixo ou misto; o cálculo das estatísticas de testes $F_{1}, F_{2}, F_{3}$ e $F_{s}$; a

\footnotetext{
${ }^{12}$ Informações sobre o pacote estão disponíveis no endereço eletrônico http://research.jax.org/faculty/churchill/
} 
obtenção de valores de significância através de métodos de permutação; a escolha de metodologias para correção dos valores de significância ( $p$-valores) devido ao problema de múltiplos testes; dentre outras coisas.

\subsection{Gráfico Vulcão}

Para resumir conjuntamente os resultados encontrados nas análises empíricas fold-change e os níveis descritivos ( $p$-valores) resultantes dos testes estatísticos aplicados para se detectar expressão gênica diferencial, uma ferramenta exploratória muito útil e de fácil interpretação usualmente utilizada em experimentos com Microarrays é o denominado gráfico vulcão (Wolfinger et al., 2001). Este gráfico contempla em sua abscissa os valores $-M_{g}$ e em sua ordenada os valores $-\log _{10}(p-$ valor), representando, respectivamente, as significâncias biológicas e estatísticas das mudanças observadas nos valores de expressão gênica de uma específica condição experimental em comparação. A Figura 9 ilustra um exemplo de gráfico vulcão.

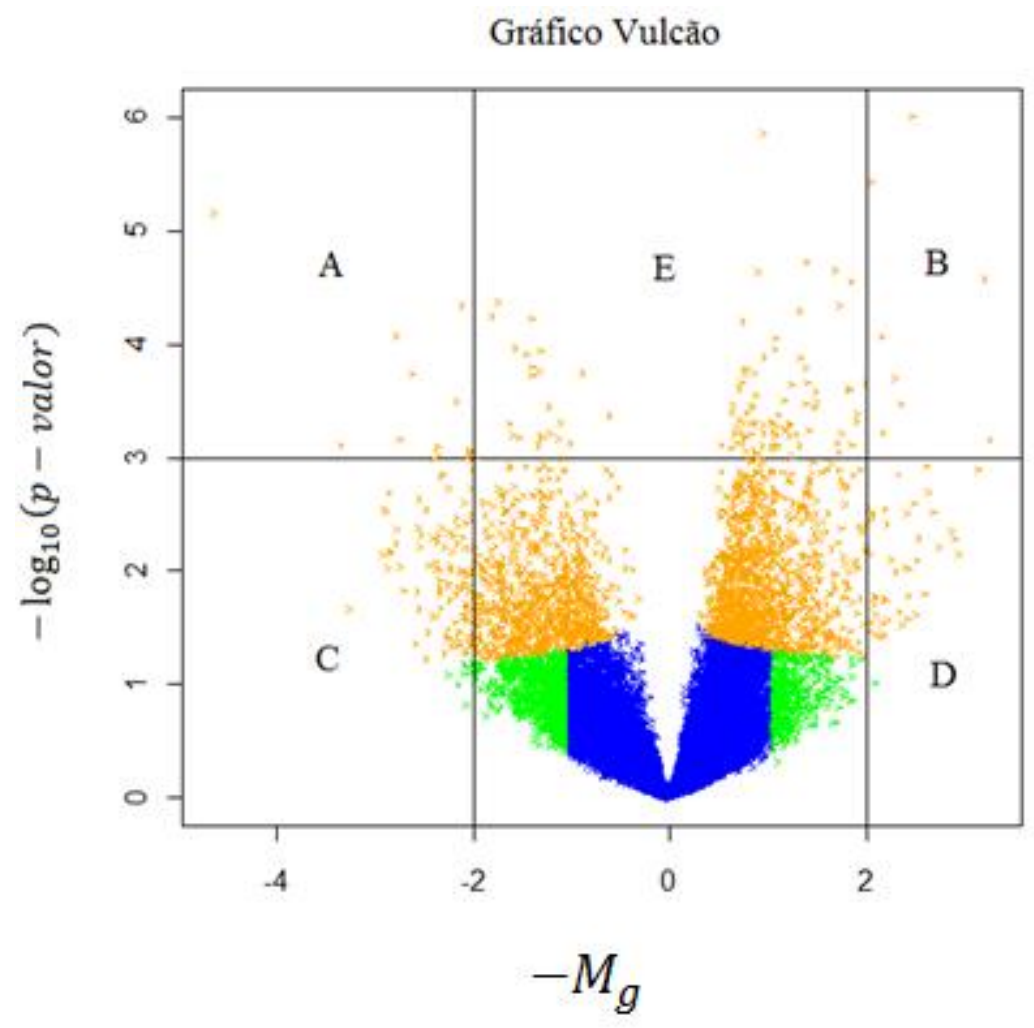

Figura 9. Ilustração do gráfico Vulcão. 
Observe que no plano cartesiano representado na Figura 9 estão presentes as informações referentes às significâncias biológicas e estatísticas para todos os genes em estudo. A interpretação realizada neste gráfico deve considerar ambas as informações e conta com a orientação de duas linhas verticais (imaginárias) e uma linha horizontal (imaginária) representando, respectivamente, os limites para classificação dos genes DE segundo os valores de fold-change (significância biológica) e $p$-valor (significância estatística) pré-estabelecidos pelo pesquisador que orienta as análises. Desta forma, são considerados como DE aqueles genes que estão presentes nas áreas $A$ e $B$. Vale destacar que através do gráfico vulcão também é possível identificar os genes que levariam aos resultados Falso-Positivos (presentes nas áreas $C$ e $D$ ) e os resultados Falso-Negativos (presentes na área $E$ ), caso o pesquisador adotar o critério fold-change. 


\section{Capítulo 4}

\section{Teoria da Resposta ao Item - TRI}

\subsection{Introdução}

Em diversas ocasiões nas quais se deseja avaliar o conhecimento latente (tácito) de indivíduos é comum o uso de metodologias de avaliação à base de provas (exames, questionários) contendo questões (itens). Em muitos dos casos a avaliação aplicada a um conjunto de indivíduos tem por finalidade a ordenação/classificação/seleção destes.

Usualmente, se opta pela elaboração e aplicação de provas que contenham itens capazes de fornecer parcelas disjuntas de informação sobre o conhecimento latente dos indivíduos e que proporcione a criação de uma escala (métrica) de dimensão latente onde seja possível posicionar sobre a mesma cada indivíduo avaliado, permitindo assim uma comparação direta entre eles (Baker, 2001). Para exemplificar, se pode citar o processo de avaliação recentemente implantado em alguns vestibulares do Brasil, onde provas são elaboradas com o propósito de se mensurar o conhecimento dos candidatos e, posteriormente, através de um critério (criação de uma métrica) seja possível realizar de forma justa a seleção dos indivíduos com melhor desempenho para preenchimento das vagas oferecidas.

Do ponto de vista técnico, os itens que compõem uma prova deveriam ser de livre resposta (dissertativos), ou seja, possibilitar que indivíduos em avaliação forneçam suas respostas de acordo com o que os mesmos acreditem ser apropriado (correto), sendo, neste caso, de responsabilidade do examinador verificar a exatidão da resposta e caracterizá-la como correta ou não. Entretanto, do ponto de vista prático, a utilização de itens de livre resposta traz dificuldades, uma vez que avaliar de maneira fidedigna tais itens como certo ou não é tarefa árdua (Baker, 2001). Outra característica associada ao emprego de provas de livre resposta é que a chance de introdução de erros na correção destas provas aumenta com o número de indivíduos (Vianna, 1973). Estas são questões relacionadas à "Análise de conteúdo", as quais, em geral, são discutidas por lingüistas. Contudo, vale ressaltar que, de maneira análoga ao contexto no qual se deseja avaliar o conhecimento latente de indivíduos, estudos de outras áreas do conhecimento como, por 
exemplo, a Psicologia, Sociologia, Marketing, Genética, etc., também se defrontam com situações onde se tem por objetivo mensurar informações latentes (variáveis latentes). Uma forma de se "conhecer" estas variáveis é fazer uso de um ou mais conjuntos de variáveis secundárias observáveis que estejam relacionadas, de alguma maneira, com a variável latente em investigação.

Uma possibilidade alternativa às provas de livre resposta é a utilização de provas (questionários) fechadas compostas por itens de múltipla escolha. Neste caso, para cada item da prova são fornecidas aos indivíduos duas ou mais opções para escolha de sua resposta, onde apenas uma alternativa é correta. A correção de itens de múltipla escolha é muito simples, recebendo o indivíduo pontuação 1 ao se fazer a opção pela alternativa correta (ou de interesse) ou pontuação 0 caso contrário, ou seja, o item é corrigido de forma dicotômica.

Apesar de apresentar alguns problemas, as correções das provas de livre resposta possibilitam um critério de correção (avaliação) mais amplo e rico, no sentido de se ter a flexibilidade de se criar mais do que dois níveis de categorizações para as respostas, o que, em princípio, deve possibilitar a extração de mais informações (maior precisão) sobre o conhecimento latente dos indivíduos.

Resultados obtidos em provas, expressos apenas por suas pontuações brutas (por exemplo, contagem de acertos) ou padronizados, têm sido tradicionalmente utilizados nos processos de avaliação e seleção de indivíduos. No entanto, os resultados encontrados dependem do particular conjunto de itens que compõem o instrumento de medida, ou seja, as análises e interpretações estão sempre associadas à prova como um todo, o que é a característica principal da Teoria Clássica das Medidas - TCM. Assim, torna-se inviável a comparação entre indivíduos que não foram submetidos às mesmas provas, ou pelo menos, ao que se denomina de formas paralelas de testes (Gulliksen, 1950; Andrade et al., 2000). Uma alternativa para se preencher esta lacuna pertinente à TCM é a utilização da Teoria da Resposta ao Item - TRI.

A TRI engloba modelos matemáticos que expressam de forma explícita a probabilidade de resposta a cada possível categoria de um item em função dos próprios parâmetros do item (características do item) e do parâmetro relacionado ao conhecimento latente do indivíduo. Estes modelos são postulados de forma que quanto 
maior o conhecimento latente do indivíduo, maior a probabilidade deste responder um item corretamente.

Uma das grandes vantagens da TRI sobre a Teoria Clássica é que ela permite a comparação entre populações, desde que submetidas a provas que tenham alguns itens comuns, ou ainda, a comparação entre indivíduos da mesma população que tenham sido submetidos a provas totalmente diferentes. Este fato decorre da própria construção da TRI, a qual tem como elemento central os itens e não a prova como um todo (Andrade et al., 2000).

Historicamente, os trabalhos pioneiros que resultaram na formulação da TRI ocorreram durante as décadas de 50 e 60. Renomados pesquisadores como Frederic M. Lord, Georg Rasch, Paul Lazarsfeld, entre outros, conduziram pesquisas paralelas e individuais, das quais resultaram contribuições importantes para a elaboração e aperfeiçoamento desta teoria.

Os primeiros modelos postulados na TRI consideravam apenas uma variável latente, de um único grupo de indivíduos, sendo mensurada a partir de itens avaliados de forma dicotômica. Inicialmente, os modelos utilizados para descrever a probabilidade de um indivíduo fornecer uma particular resposta a um item, em função do parâmetro latente do indivíduo, faziam uso da função normal acumulada (ogiva normal). Lord em 1952 foi o primeiro a desenvolver o Modelo Unidimensional de 2 parâmetros, contudo, após realizar algumas aplicações deste modelo, ele sentiu a necessidade de se incorporar ao mesmo um terceiro parâmetro que tratasse do problema do acerto casual, resultando na formulação do Modelo Unidimensional de 3 parâmetros. Independentemente do trabalho de Lord, em 1960, Rasch propôs o Modelo Unidimensional de 1 parâmetro. Ambos os modelos formulados por Lord e o modelo formulado por Rasch faziam uso da função ogiva normal para relacionar o parâmetro latente dos indivíduos à probabilidade de acerto aos itens. No entanto, em 1968, frente à complexidade matemática presente nos modelos propostos por Lord e Rasch, Allan Birnbaum e Benjamin D. Wright substituíram, em ambos os modelos propostos por Lord (no caso de Birnbaum) e no modelo proposto por Rasch (no caso de Wright), a função ogiva normal pela função logística, matematicamente mais conveniente, uma vez que esta é uma função explícita dos parâmetros do item e dos parâmetros latentes dos indivíduos, com a vantagem de não envolver cálculos de integral. 
Além dos importantes avanços que dizem respeito à quantidade de parâmetros relacionados aos itens, outra evolução marcante para a TRI foi a criação dos Modelos de Resposta Gradual. Em 1969, Fumiko Samejima, com o intuito de captar mais informações provindas das respostas dos indivíduos, introduziu o Modelo de Respostas Graduais permitindo que as avaliações dos itens pudessem ser realizadas de forma politômica. Nos anos seguintes, Bock (1972), Andrich (1978), Masters (1982) e Muraki (1992) também propuseram modelos probabilísticos que contemplam itens com duas ou mais categorias de resposta, assumindo, inclusive, diferentes estruturas entre estas categorias. Outra grande contribuição, desta vez relacionada à quantidade de populações envolvidas nos estudos, foi a introdução dos Modelos Logísticos de 1, 2 e 3 parâmetros (Bock \& Zimowski, 1977) para estudos com duas ou mais populações de indivíduos, os quais agregaram novas possibilidades de comparações entre indivíduos submetidos a diferentes testes com itens comuns.

Como descrito anteriormente, para descrever a probabilidade de um indivíduo fornecer uma dada resposta a um item, em função do parâmetro latente do indivíduo, se faz uso de uma função densidade de probabilidades (como aquelas já citada, a logística e a ogiva normal) a qual, na TRI, recebe o nome de Curva Característica do Item - CCI. Em todos os modelos as CCI são escritas em função dos parâmetros relacionados aos itens e dos parâmetros latentes dos indivíduos. Uma das etapas mais importantes e críticas na TRI é a estimação de tais parâmetros, principalmente, quando se necessita estimar tanto os parâmetros dos itens como predizer os valores das variáveis latentes (Andrade et al., 2000).

Apesar das formulações matemáticas dos modelos da TRI já estarem disponíveis na literatura desde a década de 50, a TRI só se tornou amplamente utilizada no final dos anos 70 e 80, quando o aparecimento dos computadores pessoais forneceram a capacidade de processamento necessário para aplicação desta metodologia à um grande número de indivíduos.

Nas últimas décadas, a TRI vem se tornando a técnica predominante no campo de testes em vários países como citado por Andrade et al. (2000). No Brasil, a TRI foi usada pela primeira vez em 1995 na análise dos dados do Sistema Nacional de Ensino Básico - SAEB. A partir dos resultados obtidos no SAEB, outras avaliações em larga escala, como, por exemplo, o Sistema de Avaliação de Rendimento Escolar do Estado 
de São Paulo - SARESP, também foram planejadas e implementadas de modo a serem analisadas através da TRI. Uma lista das principais aplicações da TRI no Brasil em avaliações educacionais pode ser encontrada em Andrade \& Klein (1999) e Andrade et al. (2000). Na Genética Quantitativa, como já mencionado, a TRI foi aplicada por Li \& Hong (2001) na tentativa de se encontrar genes diferencialmente expressos. Outras aplicações da TRI incluem estudos na área da psicologia (Embretson \& Reise, 2000), etc.

\subsection{Os modelos}

As diferentes propostas de modelos para a TRI presentes na literatura dependem, basicamente, de três fatores descritos a seguir (Andrade et al., 2000):

- Natureza dos itens: especificação natural ou imposta na elaboração e ou correção dos itens que compõem uma prova. Por exemplo, ao se optar pela aplicação de uma prova de múltipla escolha, naturalmente, se impõe a restrição de que os itens presentes na mesma serão de natureza dicotômica, ou seja, só duas classificações poderão ser atribuídas à resposta do indivíduo (por exemplo, “correto" ou "incorreto"). Por outro lado, ao se optar pela aplicação de uma prova de livre resposta, a imposição para determinação da natureza dos itens deve ser especificada sobre a metodologia de correção dos mesmos, uma vez que neste tipo de prova os itens podem ser corrigidos de forma dicotomizada ou politomizada. Do fator natureza dos itens surge a diferenciação entre os modelos dicotômicos e modelos politômicos.

- Número de populações envolvidas: caracterizado pelo objetivo do estudo e muito relacionado ao processo amostral especificado. Do fator número de populações envolvidas emerge os modelos para um ou mais grupos de indivíduos.

- Quantidade de variáveis latentes consideradas: caracterizado pelo que se julga plausível considerar como variável latente em um estudo. Do fator número de variáveis latentes consideradas emerge os modelos unidimensionais, quando se considera um único fator latente ou o mais predominante envolvido no estudo, e os modelos multidimensionais, quando se considera dois ou mais fatores latentes ou os mais predominantes envolvido no estudo. A tomada de decisão sobre a dimensionalidade a 
ser empregada em um estudo ainda é alvo de discussão presente na literatura, apesar de alguns autores defenderem que a aplicação de modelos unidimensionais, ainda que em situações multidimensionais, tem fornecido bons resultados (aproximação). Outros pontos que de certa forma restringem a utilização prática de modelos multidimensionais incluem a falta de recursos computacionais e a maior dificuldade de interpretação dos mesmos (Andrade et al., 2000).

Neste trabalho serão explorados alguns modelos unidimensionais para uma única população aplicados à área da Genética Quantitativa e a Genômica, como será visto mais adiante.

\subsubsection{Curva Característica do Item - CCI}

A CCI rege importante papel na TRI, sendo que as demais construções teóricas desta teoria dependem desta curva (Baker, 2001).

Uma característica das provas avaliativas é que cada item que a compõe terá sua própria CCI, isso porque em seu processo de elaboração se procura adicionar itens com diferentes graus de dificuldade para tornar possível a distinção entre os conhecimentos latentes daqueles indivíduos submetidos à mesma. Três características técnicas da CCI podem ser utilizadas para especificá-la e descrevê-la: a dificuldade, a discriminação do item e a chance de acerto ao item ao acaso.

A dificuldade de um item pode ser interpretada como um índice de localização do mesmo na escala de conhecimento latente. Por exemplo, é esperado que itens muito fáceis (difíceis) deverão estar posicionados em uma região da escala de conhecimento latente onde estarão localizados aqueles indivíduos com baixo (alto) conhecimento latente. Por outro lado, a discriminação de um item está relacionada com a capacidade na qual o mesmo irá proporcionar uma distinção entre o conhecimento latente daqueles indivíduos submetidos à prova. Esta última propriedade reflete essencialmente a inclinação da CCI, sendo que quanto mais íngreme for a inclinação da curva, maior a discriminação entre indivíduos capazes de responder incorretamente ou corretamente o item. 
Para os modelos dicotômicos explorados neste trabalho, as CCI adotadas são funções monótonas, crescentes e não lineares (em forma de "S"), com discriminação, dificuldade e acerto ao acaso definidas, respectivamente, pelos parâmetros do item $a, b$ e $c$.

Assim definidas as CCI, itens com valores para o parâmetro $a$ muito baixos produzem pouca capacidade de discriminação entre indivíduos, ou seja, indivíduos com baixos, médios ou altos valores de conhecimento latente têm probabilidades próximas de responderem tais itens corretamente. Uma conseqüência imediata para estes valores de $a$ é a descaracterização do formato "S" esperado para a CCI e a aproximação da mesma para um formato plano (ver curva em vermelho - Figura 10). Em contrapartida, itens com valores de $a$ muito altos produzem muita discriminação entre indivíduos, praticamente separando os mesmos em apenas dois grupos: indivíduos com conhecimento latente insuficiente ou suficiente para responder o item corretamente. Neste caso também ocorrerá uma descaracterização da CCI, passando esta do formato "S" para o formato vertical (ver curva em preto - Figura 10).

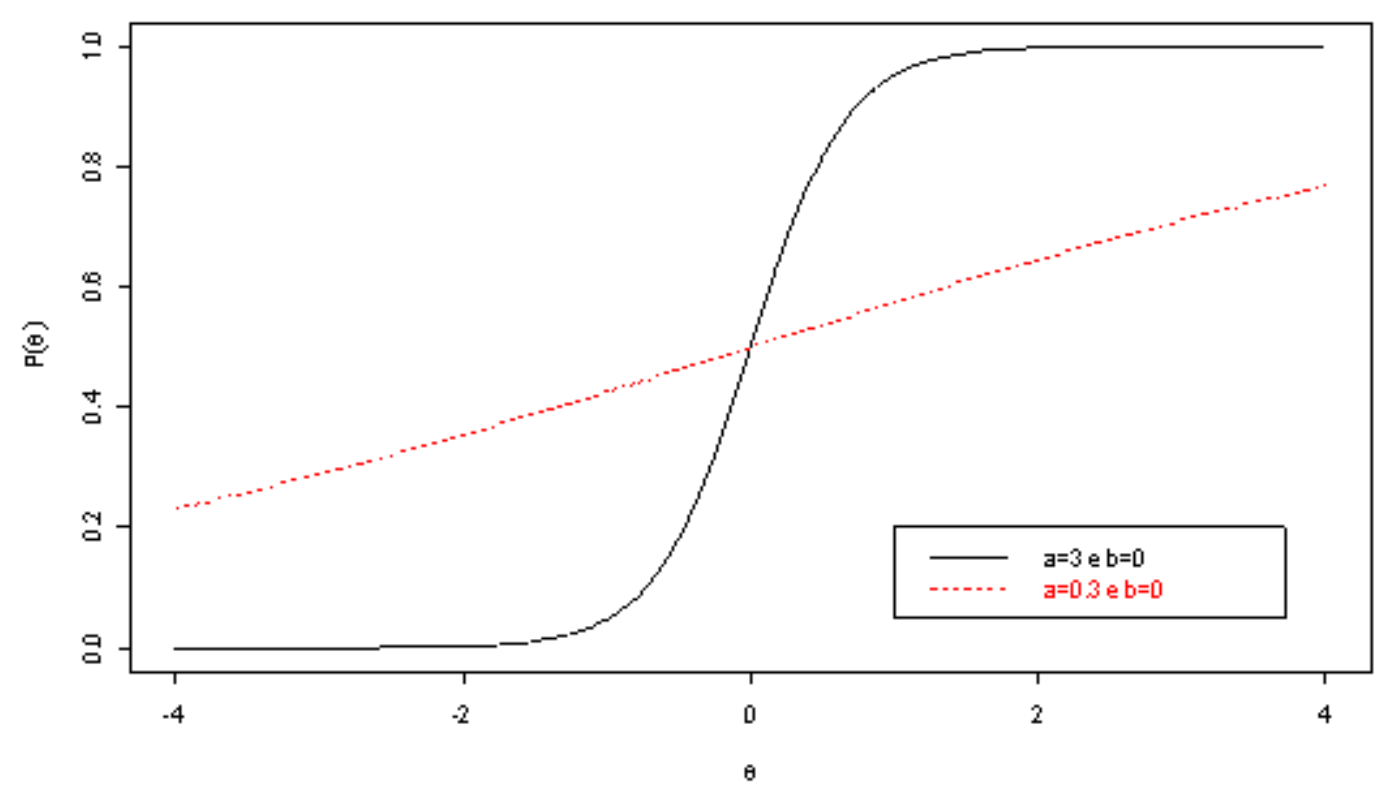

Figura 10. Ilustração de duas CCI associadas a dois itens com parâmetros de dificuldade iguais $b=0$, mas parâmetros de discriminação distintos. Os eixos $\theta$ e $P(\theta)$ 
representam, respectivamente, os valores de conhecimento latente, denotados por $\theta$, e as probabilidades de resposta correta aos itens, dado o valor $\theta$.

\subsubsection{Modelos para itens avaliados de forma dicotômica ou dicotomizados}

Os modelos para itens avaliados de forma dicotômica podem ser aplicados às provas de múltipla escolha, pois, como visto anteriormente, os itens contidos neste tipo de prova são, naturalmente, corrigidos sobre um critério dicotômico. Entretanto, estes modelos também podem ser aplicados às provas de livre resposta, desde que sejam impostas restrições que forcem a correção de todos os itens sob um critério dicotômico.

Os modelos de resposta ao item mais utilizados na prática são os Modelos Logísticos - ML. Basicamente, existem três tipos de ML denominados por ML1 ${ }^{13}$, ML2 ${ }^{14}$ e ML3 ${ }^{15}$, os quais se diferenciam pelo número de parâmetros considerados para descrever as CCI dos itens. Os ML1 são utilizados nos casos em que não há distinção entre o poder de discriminação dos itens $\left(a_{i}=a_{l}, \forall i \neq l\right.$, ) e, também, não há a possibilidade dos itens serem acertados ao acaso $(c=0)$. Os ML2 se distinguem dos ML1 pelo fato de considerarem itens com diferentes poderes de discriminação. Por fim, os ML3 além de considerarem itens com diferentes poderes de discriminação também consideram a possibilidade dos itens serem acertados ao acaso $(c \neq 0)$.

De modo a apresentar os ML1, ML2 e ML3, considere que $n$ indivíduos serão submetidos a uma prova contendo $I$ itens. Definindo a variável aleatória $Y_{i j}$ como sendo a avaliação sobre a resposta fornecida pelo $j$ - ésimo indivíduo ao $i$ - ésimo item, tal que:

$$
Y_{i j}=\left\{\begin{array}{l}
0, \text { se o } j \text { - ésimo indivíduo responder incorretamente ao } i \text { - ésimo item } \\
1, \text { se o } j \text { - ésimo indivíduo responder corretamente ao } i \text { - ésimo item }
\end{array}\right.
$$

$i=1, \ldots, I, j=1, \ldots, n$ e assumindo $Y_{i j} \sim \operatorname{Bernoulli}\left(p_{i j}\right), p_{i j}=c_{i}+\left(1-c_{i}\right) \psi\left(\zeta_{i j}\right)$ com $\zeta_{i j}=D a_{i}\left(\theta_{j}-b_{i}\right)$, onde $p_{i j}$ representa a probabilidade do $j$ - ésimo indivíduo

\footnotetext{
${ }^{13}$ ML1 um parâmetro ou Modelo Rasch.

${ }^{14} \mathrm{ML2}$ dois parâmetros.

${ }^{15}$ ML3 três parâmetros.
} 
responder corretamente ao $i$ - ésimo item, $\psi(\cdot)$ é uma função de ligação a ser adotada para relacionar $p_{i j}$ e os parâmetros $\left(a_{i}, b_{i}, c_{i}\right)$ do $i$ - ésimo item (como definidos anteriormente), dado o conhecimento latente do $j$ - ésimo indivíduo $\theta_{j}$, e, $D$ é um fator de escala constante - quando é adotada para $\psi(\cdot)$ a função acumulada da distribuição logística se tem $D=1$ ou $D=1,7$ (quando se deseja que a função acumulada da distribuição logística forneça resultado semelhante ao da função ogiva normal).

\section{Modelo Logístico Unidimensional de três parâmetros - ML3}

Sob o ML3 é pressuposto que todos os itens que compõem uma prova possuem parâmetros de discriminação distintos $\left(a_{i} \neq a_{l} \cdot, \forall i \neq l\right.$, ), parâmetros de dificuldade distintos $\left(b_{i} \neq b_{l} \cdot, \forall i \neq l,\right)$ e parâmetros relacionados à probabilidade de acerto ao acaso diferentes de zero $\left(c_{i} \neq 0, \forall i\right)$. Desta forma, após adotar para $\psi(\cdot)$ a forma acumulada da distribuição logística, o ML3 pode ser expresso por,

$$
P\left(Y_{i j}=1 \mid a_{i}, b_{i}, c_{i}, \theta_{j}\right)=c_{i}+\left(1-c_{i}\right) \frac{1}{1+e^{-D a_{i}\left(\theta_{j}-b_{i}\right)}}
$$

com, $\theta_{j}$ representando o conhecimento latente do $j$ - ésimo indivíduo (mensurado pela prova), $P\left(Y_{i j}=1 \mid a_{i}, b_{i}, c_{i}, \theta_{j}\right)$ representando a probabilidade do $j$ - ésimo indivíduo, com conhecimento latente $\theta_{j}$, responder corretamente o $i$-ésimo item, $b_{i}$ representando o parâmetro de dificuldade do $i$ - ésimo item, medido na mesma escala do conhecimento latente $\theta_{j}, a_{i}$ representando o parâmetro de discriminação (ou inclinação) do $i$ - ésimo item, $c_{i}$ representando a probabilidade de acerto do $i-$ ésimo item por um indivíduo com baixo conhecimento latente.

De modo ilustrativo, a Figura 11 apresenta as CCI para três itens construídos sobre as pressuposições do ML3, ou seja, itens com diferentes discriminações, dificuldades e possibilidade de acerto ao acaso. 


\section{Exemplo de $\mathrm{CCl}-\mathrm{ML} 3$}

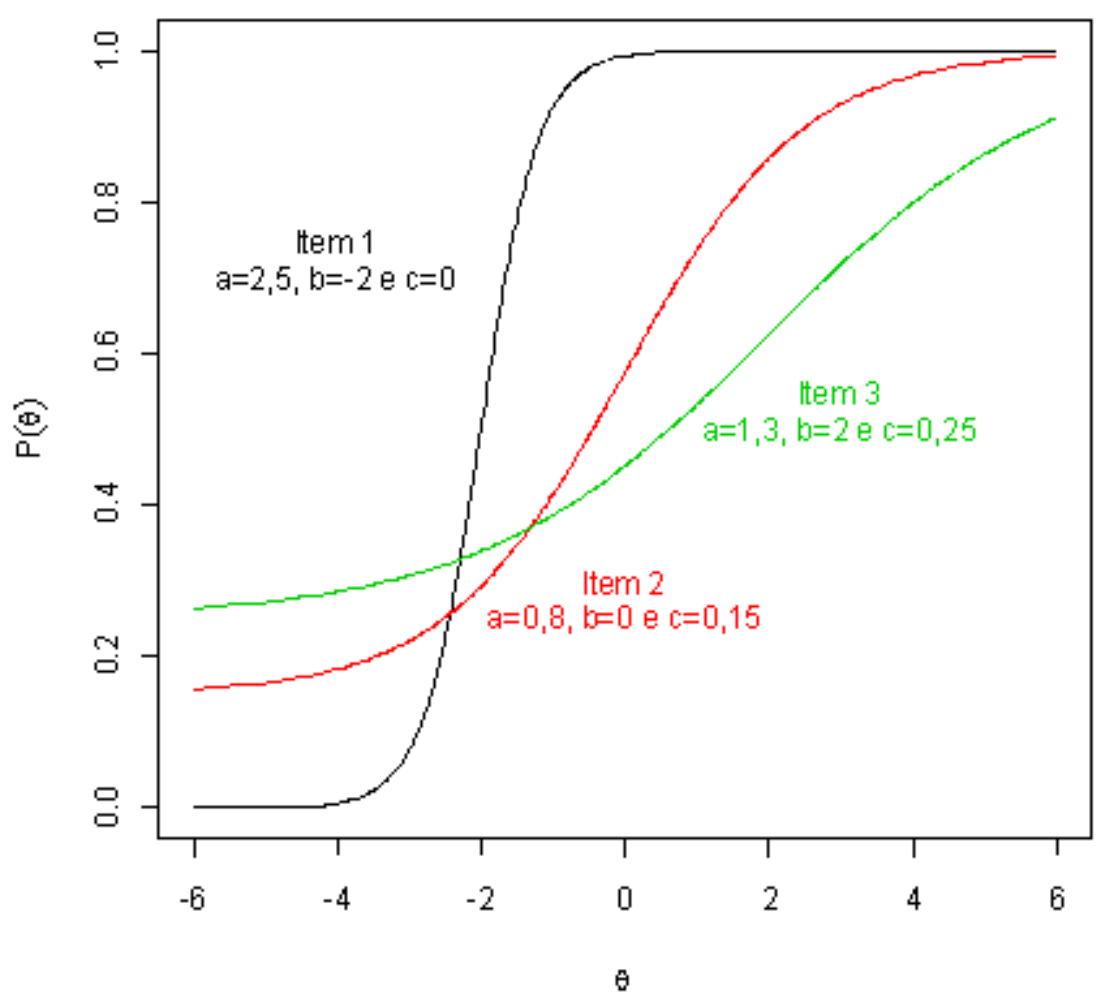

Figura 11. Ilustração de três itens com parâmetros de discriminação, dificuldade e possibilidade de acerto ao acaso distintos.

\section{Modelo Logístico Unidimensional de dois parâmetros - ML2}

No ML2 as pressuposições sobre os parâmetros de discriminação e dificuldade são as mesmas do ML3, entretanto, neste modelo se pressupõe que todos os itens que compõem a prova não podem ser acertados ao acaso $\left(c_{i}=0, \forall i\right)$. Desta forma, após adotar para $\psi(\cdot)$ a forma acumulada da distribuição logística, o ML2 pode ser expresso por,

$$
P\left(Y_{i j}=1 \mid a_{i}, b_{i}, \theta_{j}\right)=\frac{1}{1+e^{-D a_{i}\left(\theta_{j}-b_{i}\right)}}
$$


De modo ilustrativo, a Figura 12 ilustra as CCI para três itens construídos sobre as pressuposições do ML2, ou seja, itens com discriminações e dificuldades distintas entre itens e sem a possibilidade de acerto ao acaso.

Exemplo de $\mathrm{CCI}$ - ML2

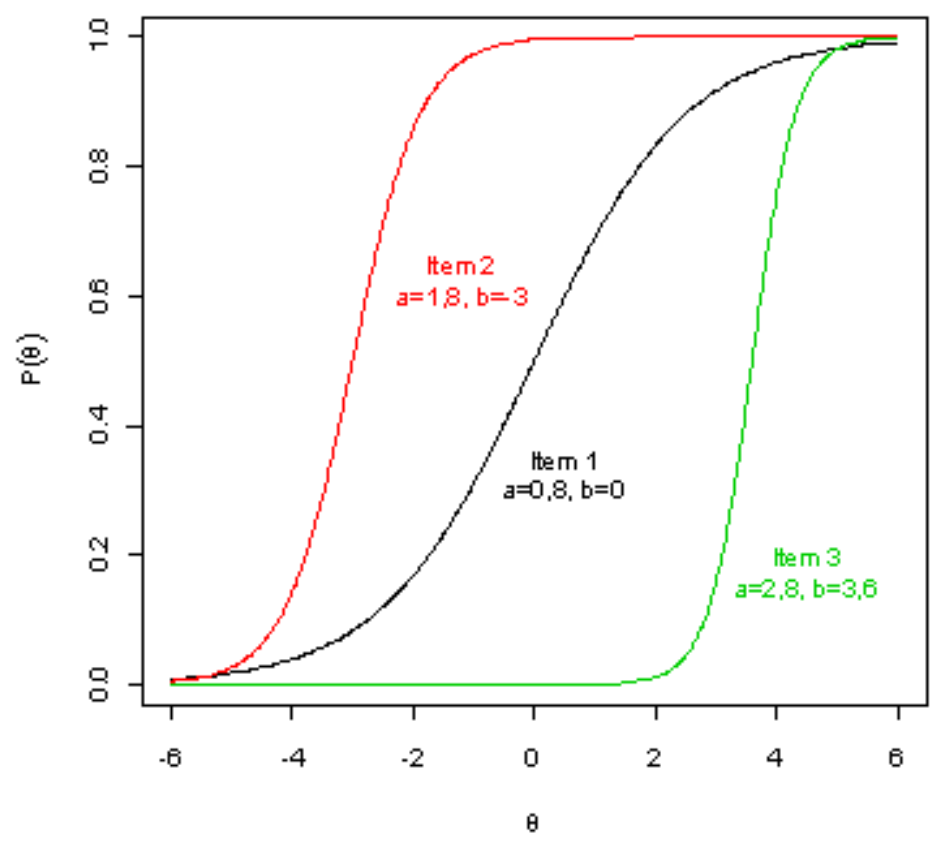

Figura 12. Ilustração de três itens com parâmetros de discriminação e dificuldade distintos e sem a possibilidade de acerto ao acaso.

\section{Modelo Logístico Unidimensional de um parâmetro - ML1 (Modelo Rasch)}

O ML1, o caso mais particular do ML3, além de não haver a possibilidade do item ser acertado ao acaso $\left(c_{i}=0, \forall i\right)$, também se pressupõe que todos os itens que compõem a prova têm o mesmo "poder" de distinção $\left(a_{i}=a_{l}=1, \forall i \neq l\right.$, $)$. Desta forma, após adotar para $\psi(\cdot)$ a forma acumulada da distribuição logística, o ML1 pode ser expresso por,

$$
P\left(Y_{i j}=1 \mid a_{i}=1, b_{i}, \theta_{j}\right)=\frac{1}{1+e^{-D\left(\theta_{j}-b_{i}\right)}}
$$


De modo ilustrativo, a Figura 13 ilustra as CCI para três itens construídos sobre as pressuposições do ML1, ou seja, itens com discriminações idênticas, dificuldades distintas e a sem a possibilidade de acerto ao acaso ao item.

\section{Exemplo de $\mathrm{CCl}$ - ML1}

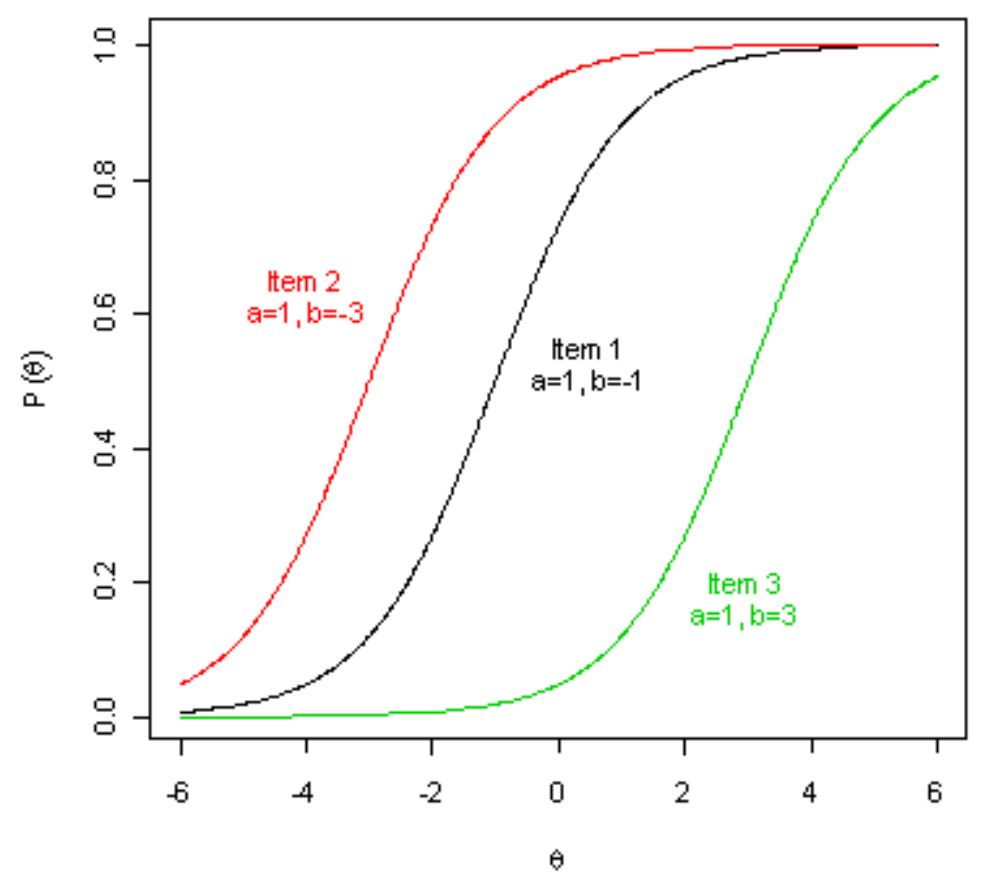

Figura 13. Ilustração de três itens com parâmetros de discriminação idênticos, parâmetros de dificuldades distintos e sem a possibilidade de acerto ao acaso.

O parâmetro de discriminação do item, $a$, como já mencionado, está relacionado à inclinação da CCI e seu valor é proporcional à derivada da tangente no ponto de inflexão da CCI. Para os ML aqui apresentados não se espera valores de a negativos, uma vez que valores como estes indicariam que a probabilidade de acerto ao item decresce com o aumento do conhecimento latente do indivíduo, o que vai contra a formulação do modelo. Por sua vez, o parâmetro de dificuldade do item, $b$, é mensurado na mesma unidade da escala de conhecimento latente. Em provas de múltipla escolha, na qual há uma probabilidade de acerto ao acaso associada ao item, $b$ representa o conhecimento latente necessário para uma probabilidade de acerto ao item igual a $(1+c) / 2$. Em contrapartida, quando não há a possibilidade de acerto ao acaso $(c=0)$, 
$b$ representa o ponto na escala de conhecimento latente no qual a probabilidade de acerto ao item é igual a 0,5 (Andrade et al., 2000).

O parâmetro $c$, por se tratar de uma probabilidade, assume valores entre 0 e 1 , entretanto, na prática, valores de $c \geq 0,35$ não são considerados aceitáveis (Baker, 2001). Outro fator importante sobre $c$ é que este não depende da escala de conhecimento latente, ou seja, todos os indivíduos possuem a mesma probabilidade de acertar um item ao acaso.

Na TRI o conhecimento latente $\theta$ pode assumir, teoricamente, valores entre $-\infty$ e $+\infty$. Deste modo, para se estabelecer uma escala de medida para $\theta$ se faz necessário determinar a métrica (origem e a unidade de medida) dos parâmetros do modelo a ser utilizado. Por exemplo, a origem e a unidade de medida podem ser escolhidas de modo a representar, respectivamente, o valor médio (uma medida de posição) e o desviopadrão (uma medida de dispersão) dos conhecimentos latentes da população em estudo. A verdadeira necessidade em se estabelecer esta métrica consiste do problema denominado por falta de identificabilidade do modelo, onde mais de um conjunto de parâmetros produzirá valores iguais na função de verossimilhança (Andrade et al., 2000).

Uma vez que a escala de conhecimento latente construída na TRI é arbitrária, sua importância está na relação de ordem entre seus pontos e não na sua magnitude. Não é difícil mostrar que neste caso o conhecimento latente de um indivíduo é invariante à escala, ou seja, a probabilidade deste responder corretamente um determinado item é sempre a mesma, independentemente da escala utilizada para medir o seu conhecimento latente (ver Andrade et al. (2000) páginas 15 e 16). Por consequiência, não faz sentido analisar itens a partir dos valores de seus parâmetros $a$ e $b$ sem antes conhecer a escala na qual estes tenham sido determinados.

Em muitas das aplicações práticas é feita a escolha da escala com média 0 e variância 1. Sob esta escala os modelos da TRI fornecem, tipicamente, valores entre -2 e 2 para os parâmetros de dificuldade dos itens $b$ e se espera valores entre 0 e 2 para os parâmetros de discriminação dos itens $a$, sendo mais apropriados valores de $a>1$.

Como já mencionado, o número de variáveis latentes consideradas em um estudo é uma dentre as três principais características utilizadas na distinção dos modelos 
da TRI. Os modelos aqui apresentados impõem a pressuposição de o conhecimento latente do indivíduo necessário para responder os itens de uma avaliação poderá ser representado por um único parâmetro, $\theta_{j}$. Esta pressuposição adotada é denominada por unidimensionalidade e, naturalmente, contra ela se poderia fazer a argumentação de que seria injusto mensurar o conhecimento de um indivíduo desconsiderando que, frente à realização de qualquer atividade, o mesmo sempre faz uso de múltiplas parcelas de seu conhecimento, devendo este ser representado por vários parâmetros $\left(\theta_{1}, \theta_{2}, \ldots, \theta_{j}, \ldots\right)$. Todavia, de modo a satisfazer a pressuposição de unidimensionalidade, é suficiente admitir que haja uma parcela do conhecimento latente do indivíduo que seja dominante e que será utilizada para responder os itens em avaliação (Andrade et al., 2000). Uma segunda pressuposição também adotada nestes modelos é a denominada independência local ou condicional, a qual postula que para um determinado valor de conhecimento latente as respostas aos itens que compõem a avaliação serão independentes.

Uma vez que unidimensionalidade implica independência local (Hambleton \& Swaminathan, 1991), uma maneira adequada para se averiguar a plausibilidade em se utilizar modelos unidimensionais consiste na verificação da dimensionalidade da avaliação (teste), a qual pode ser calculada através da metodologia de análise fatorial (por meio da matriz de correlação tetracóricas ${ }^{16}$ ) (Andrade et al., 2000) ou por procedimentos baseados no método de máxima verossimilhança (Mislevy, 1986).

\subsubsection{Modelos para itens avaliados de forma politômica}

Avaliações com itens corrigidos de forma dicotômica, em muitos casos, podem levar à perda de informações (no sentido de não se explorar ao máximo a capacidade de discriminação presente em cada item). Sob esta colocação, uma alternativa contra tal perda consiste na incorporação de mais categorias no processo de correção dos itens, a qual pode ser facilmente adaptada através, por exemplo, de provas de livre resposta ou provas de múltipla escolha, ambas corrigidas com critérios politômicos.

$\mathrm{Na}$ TRI os modelos para itens avaliados de forma politômica foram justamente desenvolvidos com o objetivo de se melhorar a precisão das estimativas do conjunto de

\footnotetext{
${ }^{16}$ Índice que mede a correlação entre os resultados dos itens de uma avaliação.
} 
conhecimento latente dos indivíduos em avaliação. Samejima (1969) introduziu o Modelo de Resposta Gradual - MRG, o qual assume que as categorias de resposta de um item podem ser ordenadas entre si.

\section{Modelo de Resposta Gradual}

Suponha que as pontuações das categorias de um item $i$ são arranjadas em ordem crescente e denotadas por $k=0,1, \ldots, m_{i}$, com $m_{i}+1$ o número de categorias do $i$ - ésimo item. Desta forma, a probabilidade do $j$ - ésimo indivíduo escolher (ou ser avaliado em) uma particular ou mais alta categoria do $i$ - ésimo item pode ser expressa por uma extensão do ML2 dada por,

$$
P_{i, k}^{+}\left(\theta_{j}\right)=\frac{1}{1+e^{-D a_{i}\left(\theta_{j}-b_{i, k}\right)}}
$$

Com $i=1, \ldots, I, j=1, \ldots, n, k=0,1, \ldots, m_{i}, b_{i, k}$ representando o parâmetro de dificuldade da $k$ - ésima categoria do $i$ - ésimo item, com a restrição $b_{i, 1} \leq b_{i, 2} \leq$ $\cdots \leq b_{i, m_{i}}$.

Os demais parâmetros em (4.2.2.1) são análogos aos definidos no ML3, com exceção da interpretação dada ao parâmetro de discriminação, o qual, neste modelo, depende tanto do parâmetro de inclinação $a$, comum a todas as categorias dos itens, quanto da distância das categorias de dificuldade adjacentes.

Assim, a probabilidade do $j$-ésimo indivíduo escolher (ser avaliado) a $k$ - ésima categoria do $i$ - ésimo item é dada pela expressão,

$$
P_{i, k}\left(\theta_{j}\right)=P_{i, k}^{+}\left(\theta_{j}\right)-P_{i, k+1}^{+}\left(\theta_{j}\right) \text {. }
$$

Para o modelo (4.3.2.1) Samejima (1969) define $P_{i, 0}^{+}\left(\theta_{j}\right)=1$ e $P_{i, m_{i}+1}^{+}\left(\theta_{j}\right)=0$ e, portanto,

$$
P_{i, 0}\left(\theta_{j}\right)=P_{i, 0}^{+}\left(\theta_{j}\right)-P_{i, 1}^{+}\left(\theta_{j}\right)=1-P_{i, 1}^{+}\left(\theta_{j}\right)
$$




$$
P_{i, m}\left(\theta_{j}\right)=P_{i, m}^{+}\left(\theta_{j}\right)-P_{i, m+1}^{+}\left(\theta_{j}\right)=P_{i, m}^{+}\left(\theta_{j}\right)
$$

Desta forma, a probabilidade do $j$ - ésimo indivíduo ser avaliado na $k$ - ésima categoria do $i$ - ésimo item pode ser expressa por,

$$
P_{i, k}\left(\theta_{j}\right)=P_{i, k}^{+}\left(\theta_{j}\right)-P_{i, k+1}^{+}\left(\theta_{j}\right)=\frac{1}{1+e^{-D a_{i}\left(\theta_{j}-b_{i, k}\right)}}-\frac{1}{1+e^{-D a_{i}\left(\theta_{j}-b_{i, k+1}\right)}}
$$

\subsection{Função de Informação do Item}

A Função de Informação do Item - FII, muito utilizada em conjunto com a CCI, traz interessantes interpretações sobre os resultados obtidos na TRI, pois através da mesma é possível saber, para toda a escala de conhecimento latente, o quanto um item agrega de informação para a medida de conhecimento latente. Em outras palavras, a FII revela a precisão na qual o conhecimento latente do indivíduo está sendo estimado (Baker, 2001). De maneira análoga à CCI, cada item que compõe a avaliação terá sua respectiva FII, a qual é definida por,

$$
I_{i}(\theta)=\frac{\left[\frac{\partial P_{i}(\theta)}{\partial \theta}\right]^{2}}{P_{i}(\theta) Q_{i}(\theta)}
$$

$P_{i}(\theta)=P\left(Y_{i j}=1 \mid a_{i}, b_{i}, \theta_{j}\right), Q_{i}(\theta)=1-P\left(Y_{i j}=1 \mid a_{i}, b_{i}, \theta_{j}\right)$ e $I_{i}(\theta)$ representando a quantidade de informação fornecida pelo $i$ - ésimo item para o conhecimento latente $\theta$.

A quantidade de informação para cada item, $I_{i}(\theta)$, pode ser plotada como uma função de $\theta$, sendo esta curva resultante denominada por Função de Informação do Item - FII. Ao se analisar a FII construída para o item $i$, a mesma deve ser interpretada da seguinte forma: quanto maior o valor desta função, ou seja, quando maior a informação agregada pelo item, maior a contribuição por parte deste item para que o conhecimento latente do indivíduo seja estimado com precisão.

Historicamente, as primeiras formulações para a quantificação da FII foram apresentadas por Birnbaum (1968). Contudo, segundo Baker \& Kim (2001), apesar das formulações apresentadas por ele estarem corretas, seu método foi fundamentado em 
um procedimento que visava a classificação de indivíduos, o qual considerava que a quantidade de informação agregada por um item provinha apenas das respostas corretas. Frente a esta colocação, Baker \& Kim (2001) apresentam um procedimento mais generalizado para quantificação da FFI proposta por Samejima (1969, 1972, 1977), o qual assume que, para um item avaliado de forma dicotômica, as diferentes categorias de resposta fornecem conjuntamente informações sobre as estimativas do conhecimento latente dos indivíduos, conceito este de fundamental importante na TRI e freqüentemente negligenciado na literatura.

Em particular, para o ML3 a FII é representada por,

$$
I_{i}(\theta)=D^{2} a_{i}^{2} \frac{Q_{i}(\theta)}{P_{i}(\theta)}\left[\frac{P_{i}(\theta)-c_{i}}{1-c_{i}}\right]^{2} .
$$

Observe que (4.3.1) depende do modelo adotado para a CCI e de seus parâmetros, sendo a quantidade $I_{i}(\theta)$ fortemente influenciada por estes. Note que $I_{i}(\theta)$ aumenta com o aumento da discriminação do item, $a_{i}$, com a diminuição da probabilidade de acerto ao acaso, $c_{i}$, e com a diminuição da distância entre $b_{i}$ e $\theta$.

\subsection{Função de Informação do Teste}

Como uma extensão da FII, a Função de Informação do Teste - FIT fornece uma medida que revela a precisão na qual os itens que compõem uma avaliação estimam o conhecimento latente dos indivíduos em toda a escala de conhecimento latente.

Uma vez que uma avaliação é composta por um conjunto de itens, digamos $I$ itens, a quantidade de informação total fornecida pela mesma, para cada nível de conhecimento latente, pode ser obtida a partir da soma das informações agregadas por cada item e expressa por,

$$
I(\theta)=\sum_{i=1}^{I} I_{i}(\theta)=\sum_{i=1}^{I} \frac{\left[\frac{\partial P_{i}(\theta)}{\partial \theta}\right]^{2}}{P_{i}(\theta) Q_{i}(\theta)}
$$


com, $I_{i}(\theta)$ representando a quantidade de formação fornecida pelo $i$ - ésimo item para o conhecimento latente $\theta$ e $I(\theta)$ representando a quantidade de informação fornecida pelo teste (todos os itens) para o conhecimento latente $\theta$.

Do ponto de vista da teoria dos testes, como é o caso da TRI, definir a FIT em termos da variância da distribuição condicional do estimador de máxima verossimilhança - EMV de $\theta$ (como é o caso em (4.4.1)) é crucial, pois proporciona uma moderna interpretação da FIT diferente daquela utilizada pelos testes clássicos, sendo um instrumento substancial para a interpretação do significado da quantidade de informação: quanto maior a quantidade de informação para um dado nível de conhecimento latente, mais próximo seu EMV estará (ao redor) do verdadeiro conhecimento latente desconhecido e, assim sendo, mais precisa será a sua estimação, (Baker \& Kim, 2001).

Também vale ressaltar que para a FIT definida em (4.4.1) a quantidade de informação presente na avaliação é gerada por cada categoria de resposta de todos os itens que compõem a mesma. De maneira análoga à FFI, a quantidade de informação para o teste, $I(\theta)$, pode ser plotada como uma função de $\theta$, sendo esta curva resultante denominada por Função de Informação do Teste - FIT.

A forma da FIT depende diretamente dos parâmetros dos itens que compõem a avaliação. Quando todos os itens de uma avaliação são equivalentes e possuem valores comuns para os parâmetros que os definem, a quantidade de informação em uma avaliação, contendo $I$ itens, será $I$ vezes a quantidade de informação de um item qualquer e, neste caso, a FIT terá a mesma forma (distribuição) de uma FII, porém mais elevada. Contudo, a situação mais comum é aquela em que os parâmetros que definem os itens são distintos (Baker \& Kim, 2001).

Outra forma interessante de expressar a FIT é através do erro-padrão de medida, denominado na TRI por erro-padrão de estimação, o qual pode ser expresso por,

$$
E P(\theta)=\frac{1}{\sqrt{I(\theta)}}
$$




\subsection{Estimação dos parâmetros na TRI}

Tipicamente, o maior interesse após a elaboração e aplicação de uma avaliação consiste de sua análise e interpretação dos resultados, havendo sempre o interesse em se estimar os parâmetros associados aos itens que compõem a avaliação e os parâmetros relacionados ao conhecimento latente dos indivíduos submetidos à mesma. O processo de estimação do conjunto de parâmetros descritos anteriormente pode ser considerado como uma das etapas mais importantes na TRI (Andrade et al., 2000).

Uma vez que nos modelos da TRI a probabilidade de um indivíduo fornecer resposta correta a um determinado item depende exclusivamente dos parâmetros dos itens e dos parâmetros relacionados ao conhecimento latente dos indivíduos e que, em geral, ambos são desconhecidos, se dispondo apenas as repostas dos indivíduos ao conjunto de itens, teoricamente, o problema de estimação pode ser dividido em três situações: $(i)$ os parâmetros dos itens são conhecidos (itens calibrados ${ }^{17}$ ), havendo a necessidade de se estimar apenas os parâmetros relacionados ao conhecimento latente dos indivíduo; (ii) os parâmetros relacionados ao conhecimento latente dos indivíduos são conhecidos, havendo a necessidade de se estimar apenas os parâmetros dos itens; (iii) ambos os parâmetros são desconhecidos e necessitam ser estimados.

Quando se está frente à situação (iii), duas abordagens usuais para estimação dos parâmetros podem ser empregadas, a saber: estimação conjunta dos parâmetros dos itens e conhecimento latente, ou estimação em duas etapas, sendo realizada inicialmente a estimação dos parâmetros dos itens e, posteriormente, a estimação dos conhecimentos latentes. No caso da estimação conjunta, o número de parâmetros a serem estimados simultaneamente (os quais dependem do tamanho da amostra e do número de itens) pode ser bastante elevado, levando a uma enorme exigência computacional (Andrade $e t$ al., 2000).

Em qualquer uma das três situações citadas acima, o processo de estimação dos parâmetros pode ser realizado tanto por métodos Clássicos, com o auxílio de métodos iterativos, quanto por métodos Bayesianos.

\footnotetext{
${ }^{17}$ Na prática, essa situação ocorre quando os itens já foram estimados em outras avaliações.
} 
Historicamente, o processo de desenvolvimento de métodos e implementação de rotinas computacionais para estimação dos parâmetros dos modelos da TRI foi bastante lento. Lord (1952) apresentou as ferramentas básicas para estimação conjunta dos parâmetros baseada na função de verossimilhança usando um modelo de ogiva normal para a CCI, entretanto, devido à ausência de recursos computacionais, sua metodologia não foi colocada em prática (Baker \& Kim, 2001).

Como pode ser notado a seguir, o processo de evolução dos métodos de estimação para os parâmetros dos modelos da TRI é marcado pela natural necessidade de se aprimorar um método de estimação já existente, mas com algumas ineficiências. Embora existam inúmeras propostas de estimação para os parâmetros dos itens e conhecimento latente, as descritas a seguir podem ser consideradas as mais importantes (Andrade et al., 2000).

As primeiras estimações na TRI foram realizadas através do método de Máxima Verossimilhança Conjunta - MVC, as quais, devido ao grande número de parâmetros presente nos modelos, necessitavam de enorme esforço computacional. Na tentativa de contornar o problema inerente ao método de MVC, Birnbaum (1968) apresentou um paradigma simplificado denominado por "back-and-forth" para a estimação conjunta dos parâmetros que se tornou a base de muitas implementações computacionais para os procedimentos de estimação por máxima verossimilhança. Todavia, apesar de Birnbaum (1968) diminuir drasticamente o problema no método de MVC, a utilização de seu procedimento para estimação dos parâmetros em uma única etapa poderia gerar problemas de inconsistências para os estimadores.

Por sua vez, o problema de possíveis inconsistências dos estimadores obtidos em uma etapa levou ao desenvolvimento de uma nova metodologia constituída de duas etapas para estimação dos parâmetros, a qual foi introduzida por Bock \& Lieberman (1970) e denominada por Máxima Verossimilhança Marginal - MVM. No método de MVM, após assumir certa distribuição de probabilidades para o conhecimento latente dos indivíduos, sem aplicar nenhum argumento bayesiano, são realizadas as estimações para os parâmetros dos itens. Etapa consecutiva consiste em utilizar as estimativas obtidas para os parâmetros dos itens, assumindo que estas representem os verdadeiros parâmetros dos itens, e realizar a estimativa dos parâmetros associado ao conhecimento latente dos indivíduos. Ambas as etapas são repetitivamente executadas até que um 
critério de convergência para as estimativas dos parâmetros seja alcançado. Maiores detalhes sobre o MVM podem ser explorados em Andersen (1980).

Apesar da solução proposta por Bock \& Lieberman (1970) ter provocado avanços para o problema de estimação, ainda era necessário que todos os parâmetros dos itens fossem estimados simultaneamente. Frente a mais este problema, Bock \& Aitkin (1981) fizeram uma modificação no modelo de Bock \& Lieberman (1970) adicionando a suposição de independência entre itens, possibilitando que os parâmetros dos itens fossem estimados individualmente. Em particular, estes autores sugeriram que estas estimativas de máxima verossimilhança fossem realizadas através da aplicação do algoritmo EM (Expectation-Maximization) introduzido por Dempster, Laird \& Rubin (1977).

Apesar da evolução dos métodos Clássicos de estimação por máxima verossimilhança, estes, em específicas situações, ainda apresentam alguns problemas. Quando um item de uma avaliação é respondido incorretamente ou corretamente por todos os indivíduos, o Estimador de Máxima Verossimilhança - EMV para o parâmetro de dificuldade do item, $b_{i}$, serão dados, respectivamente, por $-\infty$ e $+\infty$. De maneira semelhante, quando indivíduos respondem todos os itens que compõem uma avaliação incorretamente (escore nulo) ou corretamente (escore perfeito), o estimador de EMV associado ao conhecimento latente dos indivíduos, $\theta_{j}$, assumirá, respectivamente, os valores $-\infty$ e $+\infty$.

Mais recentemente, métodos Bayesianos foram propostos para resolver os problemas do método de estimação clássico por máxima verossimilhança e, também, contornar outros problemas como, por exemplo, a possibilidade de que estimativas para os parâmetros dos itens ocorram fora do intervalo esperado (valores de $a_{i}$ negativos) ou que valores de $c_{i}$ estejam fora do intervalo [0;1] (Andrade et al., 2000).

De maneira análoga à metodologia de estimação clássica, há, também, diversas propostas bayesianas para estimação dos parâmetros dos modelos empregados na TRI, sendo a mais utilizada nesta abordagem a Estimação Bayesiana Marginal proposta por Mislevy (1986), a qual é uma generalização da proposta de Bock \& Aitkin (1981).

Como o propósito deste trabalho não está vinculado à discussão dos possíveis métodos de estimação dos parâmetros na TRI, detalhes sobre este tópico, incluindo as 
formulações dos estimadores para os modelos ML1, ML2 e ML3 aqui explorados, podem ser encontrados, por exemplo, em Baker \& Kim (2001), Andrade et al. (2000) ou Azevedo (2003).

\subsection{Contextualização da TRI em experimentos de Microarray}

Como pode ser notado a partir das apresentações expostas neste capítulo, uma grande vantagem da TRI é o uso de modelos probabilísticos bem definidos para cada situação, com a particularidade de incorporarem explicitamente uma estrutura latente. Estas características possibilitam ampla generalização e aplicação desta teoria às diversas áreas do conhecimento, em diferentes contextos.

Em particular, para os estudos de Microarrays, a TRI abre margens para, dentre outras coisas: investigar se grupos de genes com padrões de expressão gênica similares estão relacionados a fenótipos (características observáveis do indivíduo); fornecer um meio alternativo de identificação daqueles genes que provavelmente estão sobreexpressos ou super-expressos a partir de seus níveis de expressão gênica mensurados, por exemplo, em diferentes tecidos ou amostras celulares; possibilitar a construção de uma escala de medida (métrica) que possibilitará o posicionamento dos genes e de amostras biológicas (itens) sobre a mesma, agregando interessantes interpretações aos resultados biológicos (Li \& Hong, 2001).

Importantes aplicações dos experimentos de Microarrays incluem os estudos entre fenótipos e os perfis de expressão gênica. Nos casos em que um fenótipo pode ser classificado em duas categorias como, por exemplo, dois tipos distintos de câncer, o problema do estudo se resume à classificação das amostras de pacientes. Neste contexto, tem sido sugerido que as expressões gênicas podem fornecer a informação adicional necessária para aperfeiçoar o processo de classificação e diagnóstico de câncer (Scherf et al., 2000). Em casos nos quais os fenótipos são informações contínuas como no caso da pressão arterial, por exemplo, o problema de interesse está em relacionar o perfil de expressão gênica à variação desta resposta na população.

Em aplicações como as descritas acima, os dados coletados nos experimentos de Microarrays são sempre estruturados em formato matricial, onde as linhas e as colunas 
da matriz representam os genes fixados no array e as amostras em estudo, ou viceversa. Neste contexto se pode representar, em paralelo à TRI, os genes (fixados nos arrays) como indivíduos (pessoas) e as amostras ou grupos sob estudo como itens. Sob esta nova leitura da estrutura matricial, por exemplo, uma versão do ML1 (Modelo Rasch) pode ser utilizada para explicar padrões de expressão gênica, dicotomizados, observados em diferentes amostras (Li \& Hong, 2001).

Dentre as poucas aplicações da TRI ao contexto de Microarrays disponíveis na literatura, Li \& Hong (2001) propuseram duas formulações do Modelo de Créditos Parciais - MCP (uma extensão do ML1) para analisar dados de expressão gênica referentes a estudos de leucemia aguda e cultura celular de câncer (NCI60), com o propósito de relacionar estes fenótipos aos padrões de expressão gênica. Adaptando as terminologias utilizadas na TRI ao contexto de Microarrays, a primeira formulação do modelo proposta por estes autores considerou as "amostras" biológicas como sendo os "indivíduos" e os "genes" como sendo os "itens". Sob esta especificação se teve por objetivo identificar diversos traços latentes associados a cada amostra biológica a partir das medidas de expressão gênica de genes avaliados nessas condições e, posteriormente, relacionar estes fatores a fenótipos observados. Em linhas gerais, nesta primeira abordagem aplicada por Li \& Hong (2001), inicialmente, como medida de redução de dimensionalidade, os $G$ fragmentos genéticos considerados no estudo foram divididos em $K$ grupos de subconjuntos de genes utilizando uma metodologia de agrupamento de variáveis. Posteriormente, para cada uma das amostras biológicas investigadas, $i=$ $1, \ldots, n$, e para cada um dos grupos criados, $k=1, \ldots, K$, o fator latente relativo à $i$ - ésima amostra e ao $k$ - ésimo grupo, $\theta_{i k}$, foi estimado a partir do ajuste de um Modelo de Créditos Parciais sobre uma amostra de valores de expressão gênica categorizados extraída do $k$ - ésimo grupo da $i$ - ésima amostra. Para concluir a análise, um modelo de regressão da forma $y_{i}=f\left(\widehat{\boldsymbol{\theta}}_{\boldsymbol{i}} ; \gamma\right)+\varepsilon_{i}$, com $\gamma$ representando o vetor dos parâmetros da regressão e $\varepsilon_{i}$ o erro do modelo, foi utilizado com o propósito de estudar o relacionamento ou a ocorrência de uma resposta de interesse $y_{i}$ observado na $i$ - ésima amostra com o vetor de fatores latentes $\widehat{\boldsymbol{\theta}}_{\boldsymbol{i}}=\left(\hat{\theta}_{i 1}, \hat{\theta}_{i 2}, \ldots, \hat{\theta}_{i K}\right)$ estimado a partir das informações genéticas dos indivíduos.

A segunda formulação proposta faz a inversão nas considerações anteriores, ou seja, se considerou "genes" como sendo os "indivíduos" e as "amostras" biológicas 
como sendo os "itens". Sob esta nova especificação se teve por objetivo identificar os diversos traços latentes associados a cada gene, utilizando suas medidas de expressão gênica sobre todas as amostras, com a finalidade de possibilitar a identificação dos genes diferencialmente expressos entre os distintos tipos de amostras consideradas. Em linhas gerais, inicialmente, $n_{i}$ amostras biológicas do $i$ - ésimo tipo são consideradas, $i=1, \ldots \mathrm{I}$, e $G$ fragmentos genéticos avaliados, indexados por $g=1, \ldots, G$. Desta forma, para o $g$ - ésimo fragmento genético, considerando os valores de expressão gênica presentes nas $n_{i}$ amostras biológicas do $i$ - ésimo tipo, o fator latente $\theta_{g i}$ pode ser estimado a partir do ajuste de um Modelo de Créditos Parciais. Realizando este processo sobre todas as $I$ distintas amostras biológicas, se terá para o $g$ - ésimo gene o vetor de fatores latentes $\widehat{\boldsymbol{\theta}}_{\boldsymbol{g}}=\left(\hat{\theta}_{g 1}, \hat{\theta}_{g 2}, \ldots, \hat{\theta}_{g I}\right)$ e, após ajustar os Modelo de Créditos Parciais para os $G$ fragmentos genéticos avaliados, a seguinte matriz de variáveis latentes estará disponível,

$$
\widehat{\boldsymbol{\theta}}=\left(\begin{array}{cccc}
\hat{\theta}_{11} & \hat{\theta}_{12} & \cdots & \hat{\theta}_{1 I} \\
\hat{\theta}_{21} & \hat{\theta}_{22} & \cdots & \hat{\theta}_{2 I} \\
\vdots & \vdots & \ddots & \vdots \\
\hat{\theta}_{(G-1) 1} & \hat{\theta}_{(G-1) 2} & \cdots & \hat{\theta}_{(G-1) I} \\
\hat{\theta}_{G 1} & \hat{\theta}_{G 2} & \cdots & \hat{\theta}_{G I}
\end{array}\right) .
$$

Por meio da ordenação das colunas de $\widehat{\boldsymbol{\theta}}$ é possível ordenar os genes com base em seus valores de expressão gênica para um específico tipo de amostra biológica. Além disso, se torna simples identificar genes que estão diferencialmente expressos (super-expressos ou sub-expressos) em cada amostra (Li \& Hong, 2001).

É importante frisar que, em ambas as abordagens descritas acima, a categorização de dados precisou ser aplicada aos valores contínuos de expressão gênica para possibilitar a aplicação do Modelo de Créditos Parciais. Diferentes critérios podem ser adotados como pontos de corte para definir as categorias de resposta como, por exemplo, os quantis da distribuição dos valores de expressão gênica. Todavia, apesar da categorização tornar as análises posteriores robustas contra pontos outliers, sua utilização pode levar a certa perda de informação (Li \& Hong, 2001).

Para enfatizar as vantagens que as aplicações da TRI agregam aos experimentos de Microarrays cabe apontar alguns de seus "ganhos" em relação às modelagens usuais, via modelos ANOVA, por exemplo. Inicialmente, pode se apontar que a 
utilização dos modelos da TRI possibilitam descrever os padrões de expressão gênica dos genes através das CCI para cada amostra a partir de modelos bem definidos e robustos a outliers. Contudo, considerando que o valor de expressão gênica obtido por meio dos experimentos de Microarrays é uma medida indireta (intensidade de luz) do fenômeno biológico que se deseja mensurar, e que, além disso a escala (distribuição) da variável gerada por estes experimentos é ainda pouco entendida no sentido de simetria, amplitude, posição e dispersão, talvez a maior vantagem seja a criação de uma escala latente para posicionar os genes segundo seus valores de expressão gênica e, também, posicionar as amostras biológicas nesta mesma escala possibilitando a realização de interessantes comparações em termos biológicos.

Neste trabalho uma exploração mais abrangente sobre a contextualização da TRI a experimentos de Microarrays será explorada e discutida a partir de um conjunto de dados reais de Microarrays, se iniciando com a contextualização do problema e se desdobrando através dos resultados obtidos. 


\section{Aplicação}

\subsection{O Experimento de Microarrays}

O laboratório de Cardiologia e Genética Molecular do instituto do Coração (InCor) conduz pesquisas direcionadas à questões que procurem revelar padrões de expressão gênica e suas relações com fenótipos cardiovasculares a partir da realização de diferentes experimentos, dentre eles os experimentos de Microarrays. Como já mencionado, o presente trabalho contou com a colaboração desta Instituição, a qual forneceu o conjunto de dados de Microarrays que proporcionou a motivação e aplicação de algumas dentre as metodologias de análise estatística aqui propostas. Inicialmente, para contextualizar o problema biológico em investigação, o experimento de Microarrays será descrito em detalhes. Em seqüência, são apresentadas as metodologias aplicadas à base de dados e os resultados obtidos. Posteriormente, são realizadas as discussões que concretizam as análises.

\section{Descrição do experimento de Microarrays fornecido pelo InCor}

O conjunto de dados explorado neste trabalho é fruto de uma pesquisa posterior aos resultados apresentados por Shork et al. $(1995)^{18}$, onde foram identificadas cinco regiões cromossômicas ( $\mathrm{CH} 2 a, \mathrm{CH} 2 c, \mathrm{CH} 8, \mathrm{CH} 4$ e $\mathrm{CH} 16)$ responsáveis por explicar, aproximadamente, $43 \%$ da variação da Pressão Arterial Sistólica (do inglês SBPS Systolic Blood Pressure) de ratos da geração F2 expostos a sobrecarga salina. Estes animais são provenientes do cruzamento de duas linhagens de rato, uma normotensa (Brown-Norway) e a outra hipertensa (SHR - Spontaneously Hypertensive Rat).

Para estudar a ação destas regiões cromossômicas na regulação da pressão arterial de ratos, uma pesquisa foi conduzida se gerando animais congênicos, isto é,

\footnotetext{
${ }^{18}$ Pesquisa direcionada para se encontrar a influência de múltiplos locos cromossômicos na variação da pressão arterial sistólica (sob a condição de sobrecarga salina) no genoma de ratos F2.
} 
animais $S H R$ modificados com cada uma das quatro regiões $(\mathrm{CH} 2 a, \mathrm{CH} 2 c, \mathrm{CH} 4 \mathrm{e}$ CH16) cromossômicas trocadas pela correspondente região do animal normotenso. As perturbações no sistema biológico dos ratos F2 utilizados no experimento do InCor foram praticadas in vivo. Considerando as regiões (QTL's - Quantitative Trati Loci) identificadas nos cromossomos $\mathrm{CH} 2 a, \mathrm{CH} 2 \mathrm{c}, \mathrm{CH} 4$ e $\mathrm{CH} 16$, linhagens congênicas de ratos espontaneamente hipertensos $(S H R)$ foram geradas por meio da substituição de cada uma destas regiões pelos correspondentes fragmentos cromossômicos de ratos puramente não hipertenso ( $B N$ - Brown-Norway), ou seja, o animal congênico $C H 2 a$ é um rato $S H R$ com a região $C H 2 a$ do animal normotenso, o animal congênico $C H 2 c$ é um rato $S H R$ com a região $C H 2 c$ do animal normotenso, e assim por diante. Maiores detalhes da análise destes dados pode ser encontrado em Schork et al. (1995).

Na sequiência do estudo da ação das quatro regiões cromossômicas na regulação da pressão de ratos, um experimento de Microarrays realizado pelo InCor foi conduzido avaliando a expressão gênica de amostras de tecidos renal de ratos $S H R$ e congênicos.

O experimento de Microarrays que originou a base de dados analisada a seguir foi elaborado sob um delineamento fatorial $5 \times 2$ (Tabela 1) com estrutura de blocos completos. Este delineamento permite estimar os "efeitos" principais e de interação entre os fatores linhagens de rato (5 níveis: $S H R$ e os quatro congênicos) e exposição a sobrecarga salina (2 níveis: basal e após sal) nos valores de expressão gênica.

Tabela 1. Delineamento fatorial $5 \times 2$ : composição dos grupos de ratos.

\begin{tabular}{|c|c|c|c|}
\hline & & \multicolumn{2}{|c|}{ Exposição à sobrecarga salina } \\
\hline & & $\operatorname{Sim}(+)$ & Não (-) \\
\hline \multirow{5}{*}{ Linhagens } & SHR & Grupo 1 & Grupo 6 \\
\hline & $\mathrm{CH} 2 \mathrm{a}$ & Grupo 2 & Grupo 7 \\
\hline & $\mathrm{CH} 2 \mathrm{c}$ & Grupo 3 & Grupo 8 \\
\hline & $\mathrm{CH} 4$ & Grupo 4 & Grupo 9 \\
\hline & CH16 & Grupo 5 & Grupo 10 \\
\hline
\end{tabular}

Para cada grupo presente na Tabela 1 foram disponibilizadas 5 réplicas de ratos, compondo desta forma os 50 ratos avaliados no experimento. A introdução da estrutura 
em blocos se fez necessária devido às restrições físicas laboratoriais, uma vez que o equipamento utilizado no processo de hibridização dos arrays permitia a hibridização conjunta de 12 arrays por vez. O esquema de alocação dos arrays no equipamento de hibridização está apresentado na Figura 14.

Bloco 1

\begin{tabular}{|l|l|l|}
\hline $\mathrm{SHR}_{(1)}^{+}$ & $\mathrm{CH} 2 \mathrm{a}_{(2)}^{+}$ & $\mathrm{CH} 2 c_{(3)}^{+}$ \\
\hline $\mathrm{CH}_{(4)}^{+}$ & $\mathrm{CH} 16_{(5)}^{+}$ & \\
\hline $\mathrm{SHR}_{(6)}^{-}$ & $\mathrm{CH} 2{a_{(7)}^{-}}^{-}$ & $\mathrm{CH} 2 c_{(8)}^{-}$ \\
\hline $\mathrm{CH}_{(9)}^{-}$ & $\mathrm{CH} 16_{(10)}^{-}$ & \\
\hline
\end{tabular}

Bloco 2

\begin{tabular}{|l|l|l|}
\hline $\mathrm{CH} 2 a_{(12)}^{+}$ & $\mathrm{CH} 4_{(14)}^{+}$ & $\mathrm{CH} 16_{(15)}^{+}$ \\
\hline $\mathrm{CH} 2 c_{(13)}^{+}$ & $\mathrm{SHR}$ & \\
\hline $\mathrm{CH} 2{a_{(11)}^{-}}^{+}$ & $\mathrm{CH} 4_{(19)}^{-}$ & $\mathrm{CH} 16_{(20)}^{-}$ \\
\hline $\mathrm{CH} 2 c_{(18)}^{-}$ & $\mathrm{SHR}$ & \\
\hline
\end{tabular}

Bloco 3

\begin{tabular}{|l|l|l|}
\hline $\mathrm{CH} 16_{(30)}^{-}$ & $\mathrm{SHR}_{(26)}^{-}$ & $\mathrm{CH} 4_{(29)}^{-}$ \\
\hline $\mathrm{CH} 2{a_{(27)}^{-}}^{-}$ & $\mathrm{CH} 2 c_{(28)}^{-}$ & \\
\hline $\mathrm{CH} 16_{(25)}^{+}$ & $\mathrm{SH}{R_{(21)}^{+}}^{-}$ & $\mathrm{CH} 4_{(24)}^{+}$ \\
\hline $\mathrm{CH} 2{a_{(22)}^{+}}^{+}$ & $\mathrm{CH} 2 c_{(23)}^{+}$ & \\
\hline
\end{tabular}

Bloco 4

\begin{tabular}{|l|l|l|}
\hline $\mathrm{CH}_{2}{c_{(38)}^{-}}^{-} \mathrm{CH} 16_{(40)}^{-}$ & $\mathrm{CH} 2 a_{(37)}^{-}$ \\
\hline $\mathrm{SHR}_{(36)}^{-}$ & $\mathrm{CH} 4_{(39)}^{-}$ & \\
\hline $\mathrm{CH} 2 c_{(33)}^{+}$ & $\mathrm{CH} 16_{(35)}^{+}$ & $\mathrm{CH} 2{a_{(32)}^{+}}^{+}$ \\
\hline $\mathrm{SHR}_{(31)}^{+}$ & $\mathrm{CH} 4_{(34)}^{+}$ & \\
\hline
\end{tabular}

Bloco 5

\begin{tabular}{|l|l|l|}
\hline $\mathrm{CH}_{(49)}^{+}$ & $\mathrm{CH} 2{c_{(48)}^{-}}^{-}$ & $\mathrm{SHR}_{(46)}^{-}$ \\
\hline $\mathrm{CH} 16_{(50)}^{-}$ & $\mathrm{CH} 2{a_{(47)}^{-}}^{-}$ & \\
\hline $\mathrm{CH} 4_{(44)}^{+}$ & $\mathrm{CH} 2 c_{(43)}^{+}$ & $S H R_{(41)}^{+}$ \\
\hline $\mathrm{CH} 16_{(45)}^{+}$ & $\mathrm{CH} 2{a_{(42)}^{+}}^{+}$ & \\
\hline
\end{tabular}

Figura 14. Esquema de alocação dos arrays no equipamento de hibridização; os sobrescritos + e - indicam, respectivamente, exposição à sobrecarga salina e não exposição à sobrecarga, respectivamente; o número subscrito entre parênteses se refere à identificação do array.

A plataforma de Oligonucleotídeos foi adotada neste experimento, embora com algumas modificações que incluem, também, características da plataforma de cDNA. Em particular, as principais características dos arrays utilizados neste estudo são: longas sequiências de probes fixadas nos spots; apenas as sequiências $P M$ foram 
utilizadas para representar os fragmentos genéticos em estudo; amostras identificadas com única coloração; ausência de réplicas de spots; presença de spots para controle da qualidade do experimento; presença de 35.129 fragmentos genéticos para avaliar os valores de expressão gênica mensurados sob as 10 diferentes condições experimentais de interesse.

Em cada um dos 50 arrays utilizados se inseriu para análise o material genético (mRNA de células renais) de um único rato. Ao término do experimento, para cada um dos arrays, um conjunto de dados (formato de planilha Microsoft Excel) contendo informações como, por exemplo, a identificação de cada fragmento genético, os valores de expressão gênica já corrigidos pelo background, os valores de expressão gênica normalizados pelo método da mediana, dentre outras informações, foi gerado pelo aplicativo CodeLink ${ }^{\mathrm{TM}}$ Expression Analysis (versão 4.1.0.29054). Após reestruturar a base completa de dados, a mesma foi importada para o aplicativo R (versão 2.7.2), o qual foi utilizado para conduzir todas as análises que serão apresentadas a seguir.

\section{Análise descritiva dos dados}

Iniciando a análise da base de dados de Microarrays, nas Tabelas 2, 3 e 4 estão apresentadas as medidas resumo para os valores brutos de expressão gênica, os valores de expressão gênica normalizada pelo método da mediana e o logaritmo (base 2) dos valores de expressão gênica normalizados pelo método da mediana, para o total de réplicas e genes. A Figura 15 mostra as distribuições dos valores de expressão gênica (à esquerda), a distribuição dos valores de expressão normalizados (central) e a distribuição do logaritmo dos valores de expressão (à direita) para a condição experimental $S H R^{+}$. 
Tabela 2. Medidas resumo para os valores de expressão gênica.

\begin{tabular}{|c|c|c|c|c|c|c|c|c|c|c|}
\hline \multirow{3}{*}{ Estatísticas } & \multicolumn{10}{|c|}{ Sobrecarga salina } \\
\hline & \multicolumn{5}{|c|}{ Presença } & \multicolumn{5}{|c|}{ Ausência } \\
\hline & SHR & CH2a & CH2c & CH4 & CH16 & SHR & CH2a & CH2c & CH4 & CH16 \\
\hline Mínimo & $-15,60$ & $-16,28$ & $-20,84$ & $-25,62$ & $-26,76$ & $-23,21$ & $-16,94$ & $-16,28$ & $-54,84$ & $-20,20$ \\
\hline 1 Quartil & 15,36 & 16,24 & 14,84 & 12,55 & 13,86 & 14,87 & 15,00 & 14,94 & 14,82 & 11,98 \\
\hline Mediana & 62,24 & 65,76 & 56,93 & 40,08 & 50,66 & 56,55 & 57,88 & 57,48 & 54,61 & 35,32 \\
\hline Média & 342,76 & 343,21 & 294,08 & 316,17 & 267,82 & 280,43 & 276,27 & 288,26 & 264,76 & 209,32 \\
\hline 3 Quartil & 246,00 & 258,62 & 217,40 & 184,53 & 189,20 & 210,78 & 213,52 & 218,61 & 202,79 & 145,82 \\
\hline Máximo & 35210,87 & 33534,55 & 33195,95 & 33197,01 & 32640,79 & 33974,57 & 32295,14 & $+30832,96$ & 34774,74 & 33916,54 \\
\hline NA & 1017 & 1061 & 1041 & 910 & 1098 & 1153 & 1066 & 974 & 1031 & 1000 \\
\hline
\end{tabular}

Tabela 3. Medidas resumo para os valores de expressão gênica normalizados.

\begin{tabular}{|c|c|c|c|c|c|c|c|c|c|c|}
\hline \multirow{3}{*}{ Estatísticas } & \multicolumn{10}{|c|}{ Sobrecarga salina } \\
\hline & \multicolumn{5}{|c|}{ Presenca } & \multicolumn{5}{|c|}{ Ausência } \\
\hline & SHR & CH2a & $\mathrm{CH} 2 \mathrm{c}$ & CH4 & CH16 & SHR & CH2a & CH2c & CH4 & CH16 \\
\hline Mínimo & $-0,81$ & $-0,88$ & $-0,96$ & $-0,88$ & $-0,71$ & $-0,64$ & $-0,63$ & $-0,73$ & $-1,34$ & $-1,19$ \\
\hline 1 Quartil & 0,31 & 0,31 & 0,33 & 0,37 & 0,34 & 0,32 & 0,31 & 0,35 & 0,34 & 0,36 \\
\hline Mediana & 1,03 & 1,03 & 1,03 & 1,02 & 1,03 & 1,05 & 1,03 & 1,03 & 1,03 & 1,03 \\
\hline Média & 5,08 & 4,85 & 4,71 & 4,96 & 4,91 & 4,72 & 4,63 & 4,64 & 4,47 & 4,50 \\
\hline 3 Quartil & 3,88 & 3,86 & 3,76 & 3,60 & 3,83 & 3,87 & 3,81 & 3,88 & 3,76 & 3,51 \\
\hline Máximo & 1254,30 & 1583,86 & 1053,81 & 1232,45 & 847,06 & 843,00 & 810,34 & 1032,75 & 798,40 & 728,80 \\
\hline NA & 1017 & 1061 & 1041 & 910 & 1098 & 1153 & 1066 & 974 & 1031 & 1000 \\
\hline
\end{tabular}

Tabela 4. Medidas resumo para o logaritmo (base 2) dos valores de expressão gênica normalizados.

\begin{tabular}{|c|c|c|c|c|c|c|c|c|c|c|}
\hline \multirow{3}{*}{ Estatísticas } & \multicolumn{10}{|c|}{ Sobrecarga salina } \\
\hline & \multicolumn{5}{|c|}{ Presença } & \multicolumn{5}{|c|}{ Ausência } \\
\hline & SHR & CH2a & $\mathrm{CH} 2 \mathrm{c}$ & CH4 & CH16 & SHR & CH2a & CH2c & CH4 & CH16 \\
\hline Mínimo & $-12,96$ & $-12,47$ & $-12,18$ & $-14,23$ & $-13,04$ & $-12,33$ & $-12,79$ & $-12,65$ & $-12,16$ & $-12,31$ \\
\hline 1 Quartil & $-1,59$ & $-1,56$ & $-1,50$ & $-1,29$ & $-1,44$ & $-1,52$ & $-1,57$ & $-1,41$ & $-1,45$ & $-1,32$ \\
\hline Mediana & 0,05 & 0,05 & 0,05 & 0,03 & 0,05 & 0,06 & 0,04 & 0,04 & 0,05 & 0,04 \\
\hline Média & 0,24 & 0,23 & 0,24 & 0,27 & 0,28 & 0,25 & 0,22 & 0,27 & 0,24 & 0,28 \\
\hline 3 Quartil & 1,96 & 1,95 & 1,91 & 1,85 & 1,94 & 1,95 & 1,93 & 1,95 & 1,91 & 1,81 \\
\hline Máximo & 10,29 & 10,63 & 10,04 & 10,27 & 9,73 & 9,72 & 9,66 & 10,01 & 9,64 & 9,51 \\
\hline NA & 1017 & 1061 & 1041 & 910 & 1098 & 1153 & 1066 & 974 & 1031 & 1000 \\
\hline
\end{tabular}



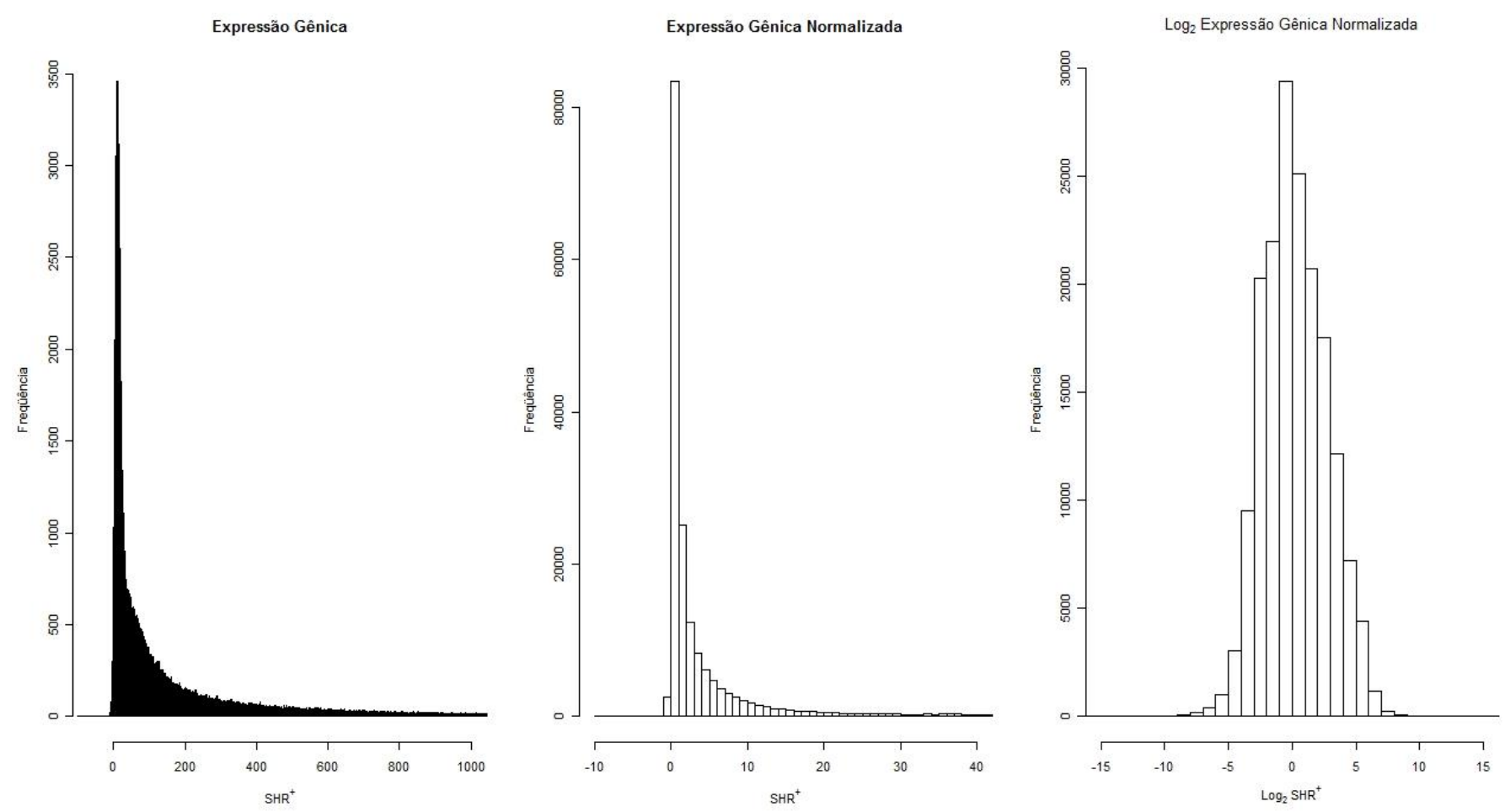

Figura 15. Distribuição dos valores de expressão gênica, expressão gênica normalizada e logaritmo dos valores de expressão gênica para a condição experimental SHR ${ }^{+}$.

Pelos resultados da Tabela 2 e Figura 15 (à esquerda), se pode notar que para a condição experimental $\mathrm{SHR}^{+}$a distribuição dos valores de expressão gênica (bruta e corrigida) apresenta forte assimetria, caudas longas à direita com grandes diferenças de grandeza entre estes valores. A transformação logarítmica corrige bastante tal assimetria e ordens de grandeza (ver Tabela 4 e Figura 15, à direita).

Embora as Tabelas 2, 3 e 4 e a Figura 15 sejam informativas para se ter idéia das distribuições dos valores de expressão gênica, estas não permitem visualizar a distribuição individual dos valores de expressão gênica para cada réplica experimental, isto é, possíveis variações nos valores de expressão gênica entre réplicas experimentais sob a mesma ou diferentes condições experimentais. A Figura 16 traz os gráficos de caixa que representam as distribuições dos valores de expressão das 5 réplicas avaliadas sob a condição experimental $S H R^{+}$. 

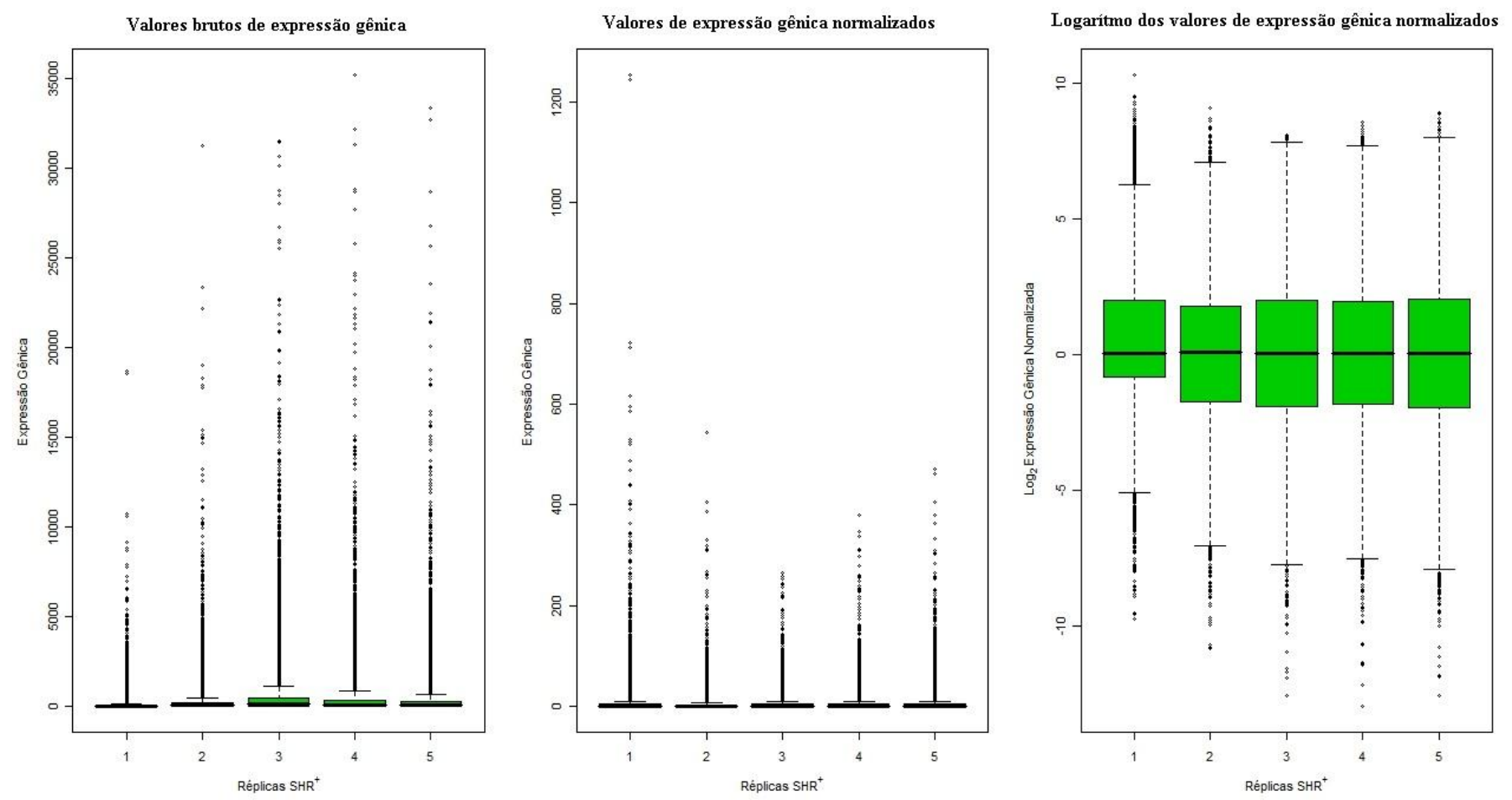

Figura 16. Distribuições dos valores de expressão gênica das 5 réplicas sob a condição experimental $\mathrm{SHR}^{+}$.

A partir da Figura 16 (e Figuras do Apêndice A) já é possível notar, visualmente, diferenças na variabilidade dos valores de expressão gênica entre réplicas avaliadas sob mesmas ou diferentes condições experimentais, para o conjunto total de genes.

Como pode ser visto na Tabela 2, 3 ou 4, apenas uma pequena proporção de valores $(\cong 0,59 \%)$ de expressão gênica não foram coletados para cada condição experimental. Apesar de cada array conter 35.129 fragmentos genéticos a serem analisados, se decidiu por proceder com as análises utilizando 33.586 fragmentos genéticos, dos quais se tinha os valores de expressão gênica observados para todos os 50 ratos avaliados. Os 1.543 fragmentos genéticos com pelo menos uma perda de informação foram excluídos.

O principal objetivo deste experimento é encontrar, dentre os 33.586 fragmentos genéticos, aqueles que estão diferencialmente expressos sob as distintas condições experimentais avaliadas. Na tentativa de se atingir este objetivo, as metodologias de ANOVA e a TRI foram contextualização e aplicadas à base de dados em discussão. A seguir são apresentados os resultados obtidos sob as duas metodologias. 


\subsection{Modelos de ANOVA para Microarrays - MAANOVA}

Dado que se utilizou um delineamento fatorial $5 \times 2$ com estrutura de blocos completos, com o propósito de se estudar os efeitos individuais e de interação dos fatores " $A$ " (linhagem) - representando as mudanças na estrutura biológica (5 níveis) e "B" (sobrecarga salina) - representando a exposição à sobrecarga salina (2 níveis) sob os valores de expressão gênica, para cada um dos 33.586 fragmentos genéticos, foi proposto o seguinte modelo linear,

$$
y_{i g l p k}=\mu_{g}+C_{g l}+S_{g p}+C S_{g l p}+B_{g k}+\varepsilon_{i g l p k}\left\{\begin{array}{l}
l=1, \ldots, a \\
p=1, \ldots, b \\
k=1, \ldots, n \\
g=1, \ldots, G
\end{array}\right.
$$

com $a=5$ representando os níveis do fator $A(S H R, C H 2 a, C H 2 c, C H 4$ e CH16), $b=2$ representando os níveis do fator $B$ (presença de sal " + ", ausência de sal "- "), $n=5$ representando o número de blocos, $G=33.586$, (sob a parametrização em (5.2)) $\mu_{g}$ representando a média geral de expressão do $g$ - ésimo gene, $C_{g l}$ representa o "efeito" principal do fator $A$ ( $l$ - ésimo congênico), $S_{g p}$ representa o "efeito" principal do fator $B$ ( $p$ - ésima sobrecarga salina), $C S_{g l p}$ representa o "efeito" de interação entre o fator $A$ e $B(A B)$ (o $l$ - ésimo congênico e a $p$ - ésima sobrecarga salina), $B_{g k}$ representa o "efeito" do $k$ - ésimo bloco, $y_{i g l p k}$ representando o logaritmo (base 2) do valor de expressão normalizado do $i$ - ésimo rato pertencente ao $l$ - ésimo congênico avaliado sob a $p$ - ésima sobrecarga salina mensurado no $k$ - ésimo bloco e $\varepsilon_{i g l p k}$ o erro aleatório.

Todos estes efeitos são específicos ao $g$-ésimo fragmento genético e avaliados separadamente para cada gene. No modelo (5.1) é preciso impor restrições com a finalidade de que todos os parâmetros sejam estimáveis. Mais especificamente,

$$
\sum_{l=1}^{5} C_{g l}=\sum_{p=1}^{2} S_{g p}=\sum_{l=1}^{5} C S_{g l p}=\sum_{p=1}^{2} C S_{g l p}=\sum_{k=1}^{5} B_{g k}=0
$$


A significância estatística dos efeitos principais e de interação entre os fatores $A$ e $B$ pode ser obtida a partir dos valores obtidos para a estatística $F$, sob premissas clássicas de que os erros são independentes e identicamente distribuídos como uma Normal com média zero e variância $\sigma_{g}^{2}$, para o $g$-ésimo gene. Para dados de Microarrays como mencionado no capítulo 3, propostas alternativas à estatística $F$ podem ser utilizadas. Em particular, as estatísticas $F_{1}, F_{2}, F_{3}$ propostas por Cui \& Churchill (2003) e a estatística $F_{S}$ proposta por Cui et al. (2005) podem ser adotadas:

$$
F_{1_{g}}=\frac{\Delta_{g}}{\hat{\sigma}_{g}^{2}}, \quad F_{2}=\frac{\Delta_{g}}{\frac{1}{2}\left(\hat{\sigma}_{g}^{2}+\hat{\sigma}_{\text {pool }}^{2}\right)}, \quad F_{3}=\frac{\Delta_{g}}{\hat{\sigma}_{\text {pool }}^{2}}, \quad F_{S}=\frac{\Delta_{g}}{\tilde{\sigma}_{g}^{2}}
$$

com $\Delta$ representando o quadrado médio associado a um "efeito", $\hat{\sigma}_{g}^{2}$ representa o quadrado médio residual específico do gene $g, \hat{\sigma}_{\text {pool }}^{2}$ o quadrado médio residual global calculado com base em todos os genes e $\widetilde{\sigma}_{\mathrm{g}}^{2}$ o quadrado médio residual calculado a partir do estimador James-Stein (Lindley, 1962). Como discutido anteriormente, a decisão por se escolher um específico denominador da estatística $F$ deve estar respaldada no que se julga plausível assumir para a variância entre genes. Contudo, Cui et al. (2005) compara a estatística $F_{S}$ com diversas estatísticas $\left(F_{1}, F_{2}, F_{3}\right.$, a estatística $t$-regularizada, a estatística razão de chances a posteriori bayesiana) para se testar expressão diferencial e conclui, através de simulações com diversos conjuntos de dados nos quais as componentes de variância associadas a cada gene são heterogêneas ou homogêneas, que a estatística $F_{S}$ possui quase sempre o melhor poder para detectar genes diferencialmente expressos. Frente às colocações de Cui et al. (2005), a estatística $F_{S}$ será adotada para testar a significância do efeito de interesse. O pacote maanova do $\mathrm{R}$ foi utilizado no ajuste do modelo (5.1) e cálculo das estatísticas $F_{S}$ para os dados sob estudo.

No caso em que o efeito de interação entre os fatores linhagem e condição de sal foi significativo, se passou a estudar o efeito de linhagem em cada nível da condição sal, bem como o efeito de sal dentro de cada linhagem, por meio de contrastes específicos. Como medida de correção para múltiplos testes, o pacote maanova permite que a 
significância estatística obtida seja corrigida por meio do procedimento FDR "adaptative" (ver capítulo 3).

Considerando os interesses dos pesquisadores do InCor, dentro de cada condição de sal (basal e após dieta de sal) foram estimados e testados 4 contrastes entre médias de expressão gênica (na escala $\log _{2}$ ): $\mu_{S H R}-\mu_{C H 2 a}, \mu_{S H R}-\mu_{C H 2 C}, \mu_{S H R}-$ $\mu_{C H 4}$ e $\mu_{S H R}-\mu_{C H 16}$. Do mesmo modo, dentro de cada linhagem foi estimado e testado a diferença entre médias na condição basal e após dieta de sal. Assim, no total, sob efeito de interação significativo, foram estudados $13(4+4+5)$ contrates de interesse.

Uma vantagem ao se aplicar a ANOVA para dados de Microarrays é que por meio desta, além de ser possível encontrar a significância estatística, a significância biológica $\left(M_{g}\right)$ acaba sendo naturalmente estimada (por exemplo, $\hat{\mu}_{S H R}^{+}-\hat{\mu}_{C H 2 c}^{+}$) por meio contrastes.

Como forma de resumir e apresentar os resultados da MAANOVA, foram construídos 13 gráficos vulcão (como proposto por Wolfinger et al., 2001). Este gráfico permite a visualização simultânea da significância estatística (no eixo das ordenadas) e a "significância" biológica (no eixo das abscissas) de um particular efeito para o conjunto total de genes sob análise. A significância estatística está associada aos valores $-\log _{10}(p-v a l o r)$ do teste do efeito de cada gene e a "significância" biológica está associada às estimativas do correspondente efeito (contrastes de interesse).

Nas Figuras 17, 18, 19 e 20 estão apresentados os gráficos vulcão para as comparações entre médias de cada linhagem de congênico ( $\mathrm{CH} 2 a, \mathrm{CH} 2 \mathrm{c}, \mathrm{CH} 4, \mathrm{CH} 16)$ com a linhagem de animais hipertensos SHR na condição basal (denotada por “-") e na condição após sal (denotada por “+”). Nas Figuras 21 e 22 estão apresentados os gráficos vulcão para as comparações entre condição basal e sal para cada linhagem.

Nestes gráficos, na abscissa estão indicadas retas verticais que definem genes com $\left|M_{g}\right|>2$ como biologicamente significativos, isto é, aqueles genes com média de expressão diferencial (na escala $\log _{2}$ ) suficientemente alta na avaliação clínica do pesquisador. No ordenada dos gráficos está indicada a reta de significância estatística segundo o método FDR. Deste modo, somente os genes classificados nos quadrantes 
$\left|M_{g}\right|>2 \cap-\log _{10}(p-$ valor $)>p_{F D R}-$ valor são considerados diferencialmente expressos.
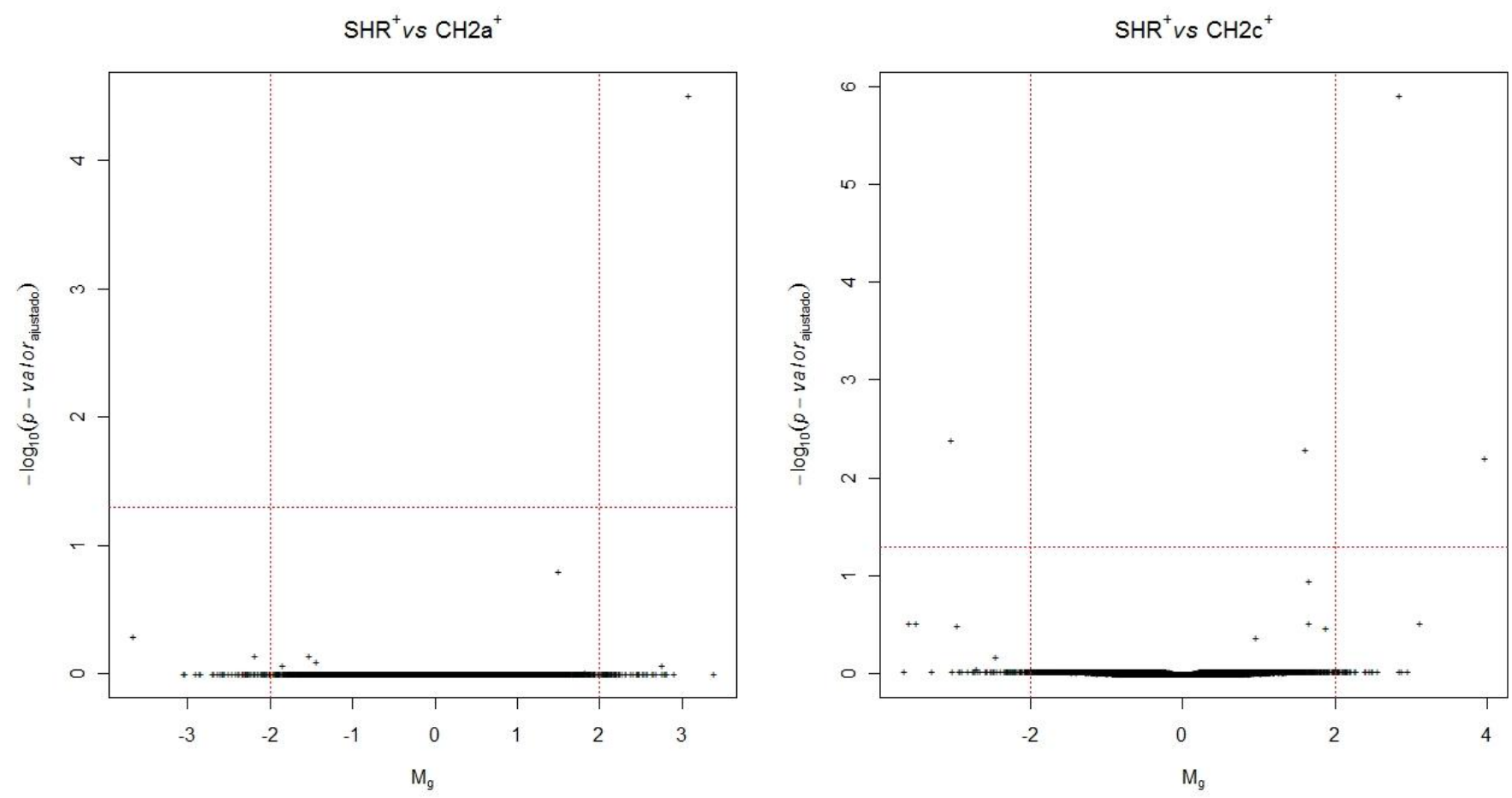

Figura 17. Gráfico vulcão para as hipóteses $\mathrm{H}_{0}: \mu_{\mathrm{SHR}}^{+}-\mu_{\mathrm{CH} 2 \mathrm{a}}^{+}=0$ (à esquerda) e $\mathrm{H}_{0}: \mu_{\mathrm{SHR}}^{+}-\mu_{\mathrm{CH} 2 \mathrm{c}}^{+}$(à direita).
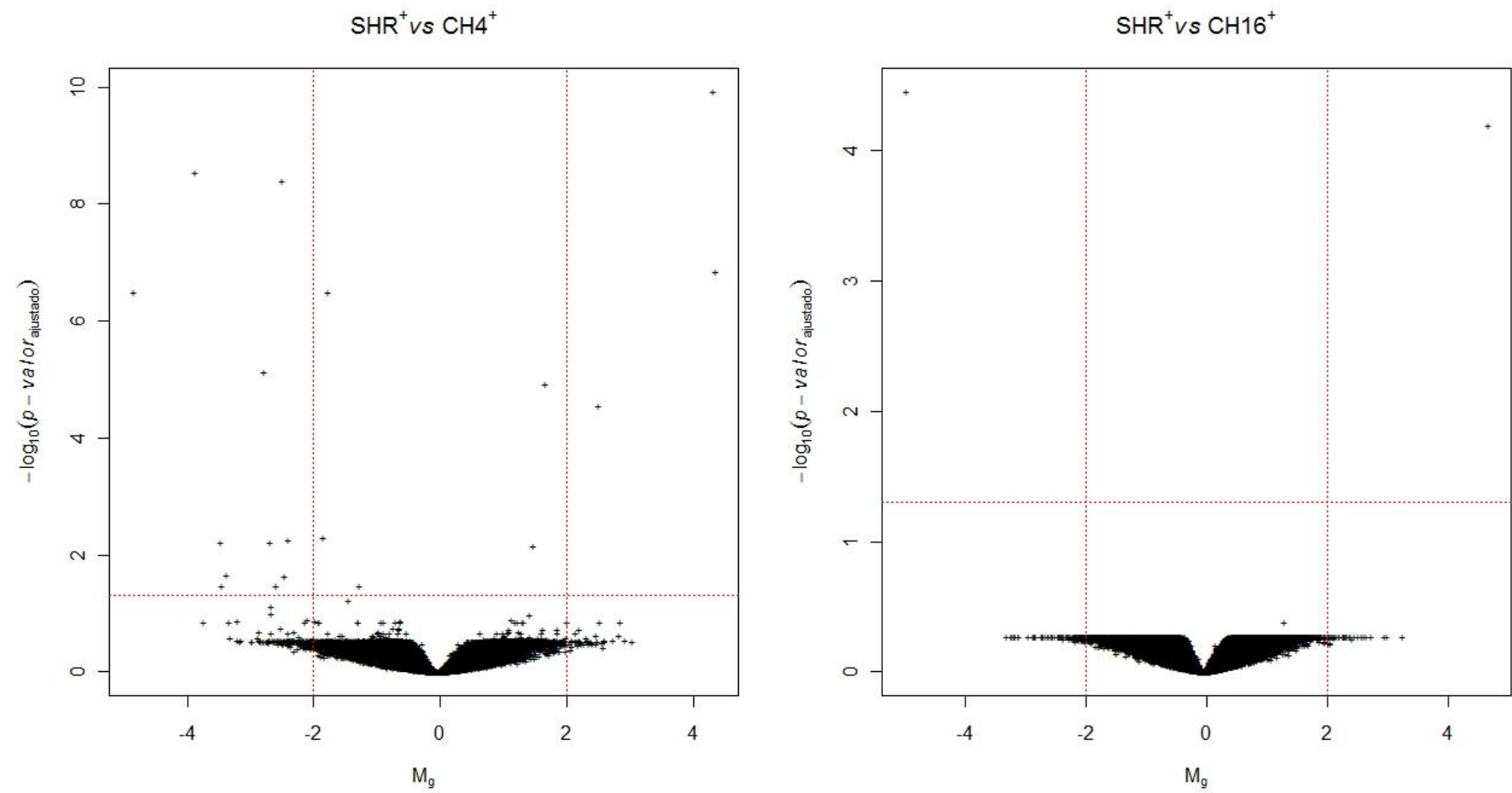
Figura 18. Gráfico vulcão para as hipóteses $\mathrm{H}_{0}: \mu_{\mathrm{SHR}}^{+}-\mu_{\mathrm{CH} 4}^{+}=0$ (à esquerda) e

$$
\mathrm{H}_{0}: \mu_{\mathrm{SHR}}^{+}-\mu_{\mathrm{CH} 16}^{+}=0 \text { (à direita). }
$$
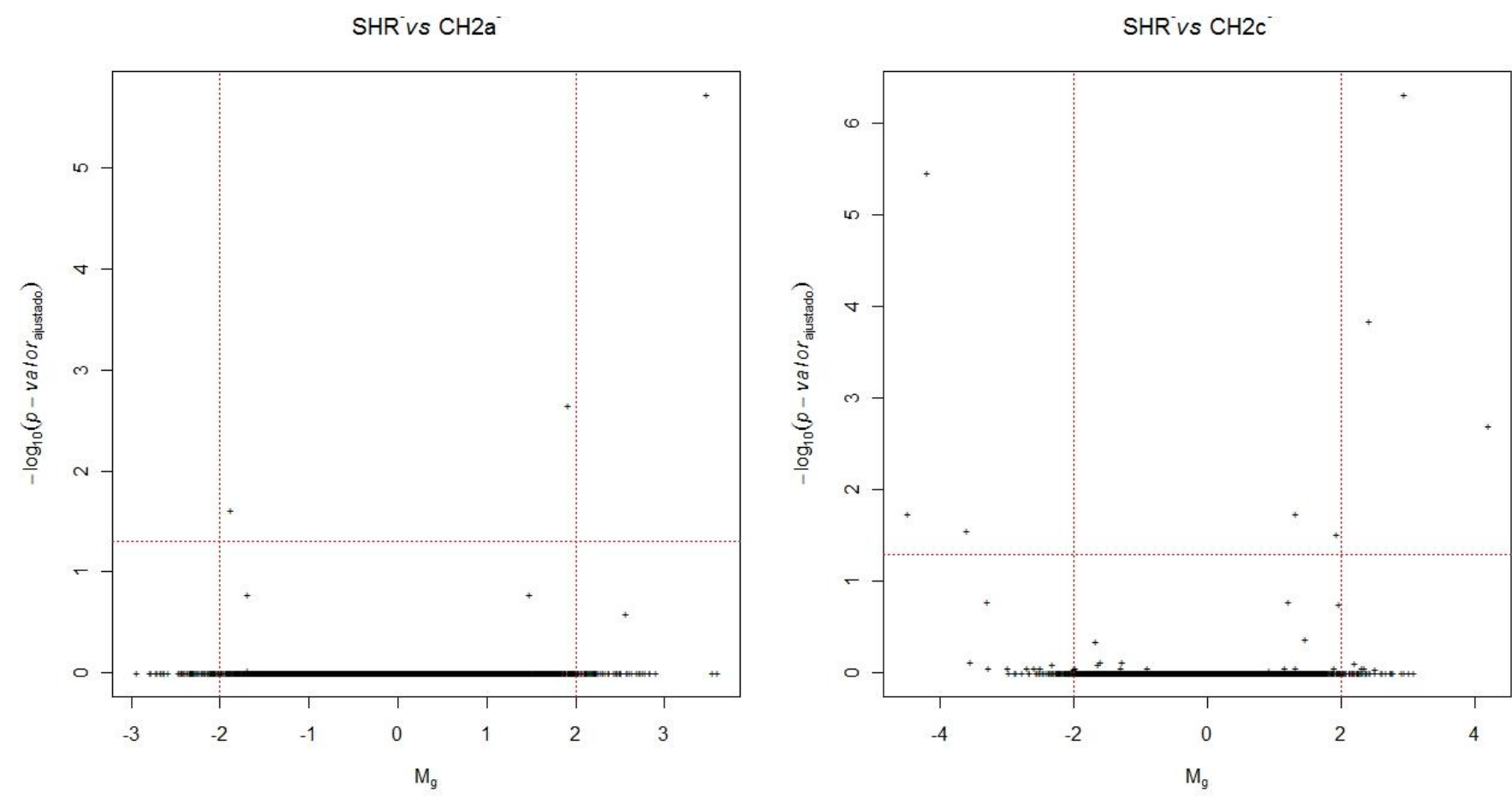

Figura 19. Gráfico vulcão para as hipóteses $\mathrm{H}_{0}: \mu_{\mathrm{SHR}}^{-}-\mu_{\mathrm{CH} 2 \mathrm{a}}^{-}=0$ (à esquerda) e $H_{0}: \mu_{S H R}^{-}-\mu_{C H 2 c}^{-}=0$ (à direita). 

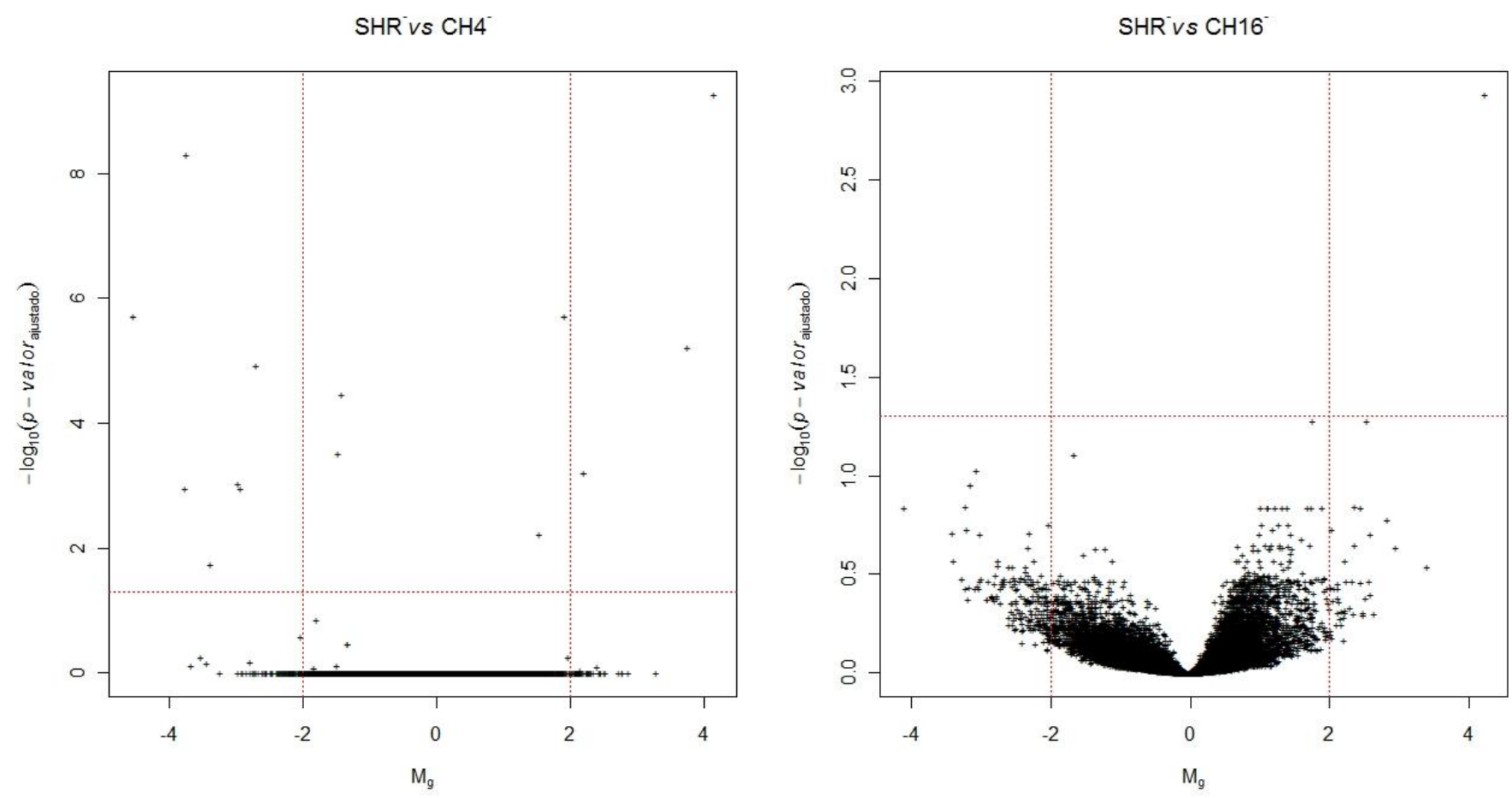

Figura 20. Gráfico vulcão para as hipóteses $H_{0}: \mu_{S H R}^{-}-\mu_{C H 4}^{-}=0$ (à esquerda) e $H_{0}: \mu_{S H R}^{-}-\mu_{C H 16}^{-}=0$ (à direita).
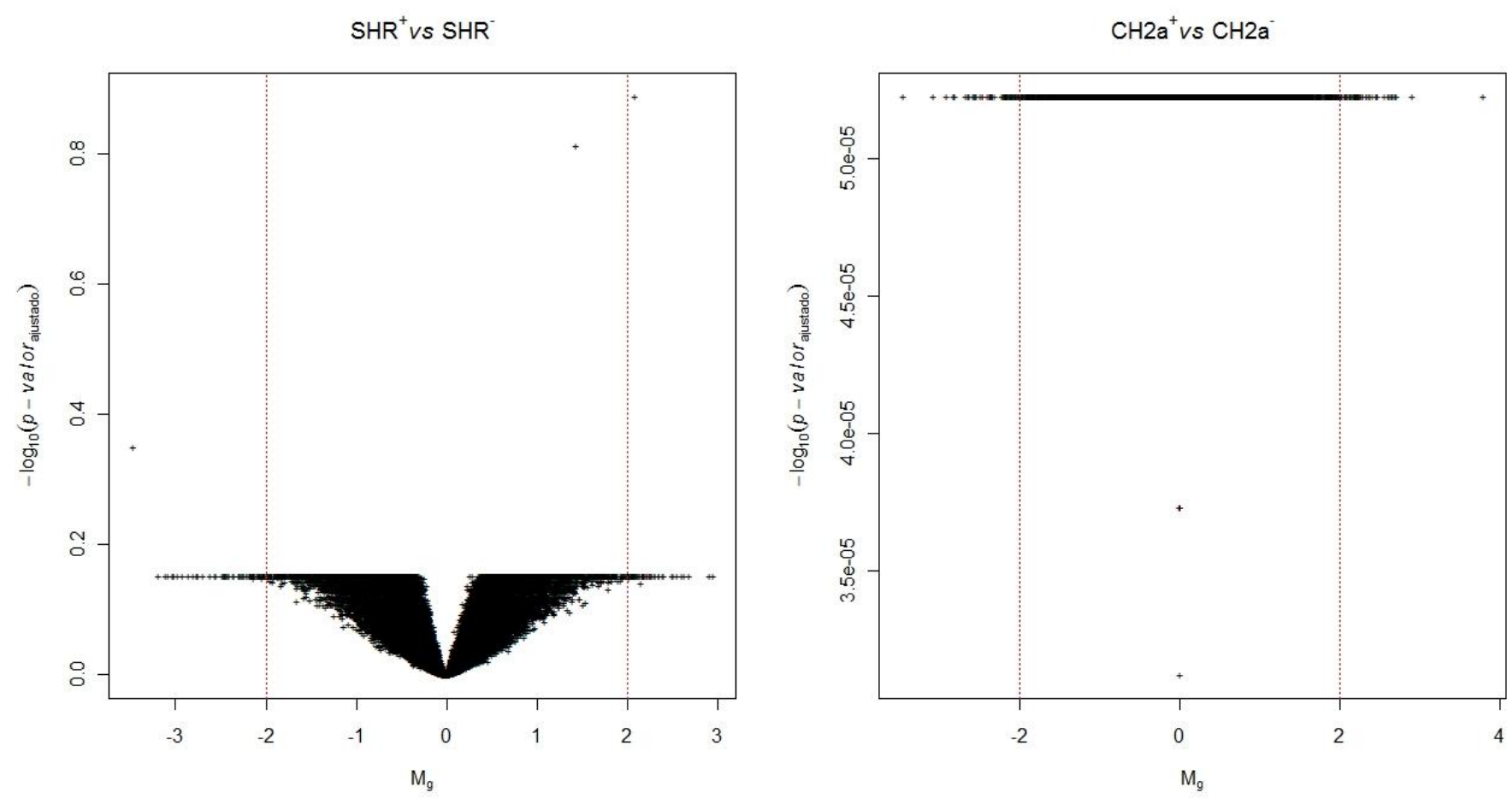

Figura 21. Gráfico vulcão para as hipóteses $H_{0}: \mu_{S H R}^{+}-\mu_{S H R}^{-}=0$ (à esquerda) e $H_{0}: \mu_{C H 2 a}^{+}-\mu_{C H 2 a}^{-}=0$ (à direita). 

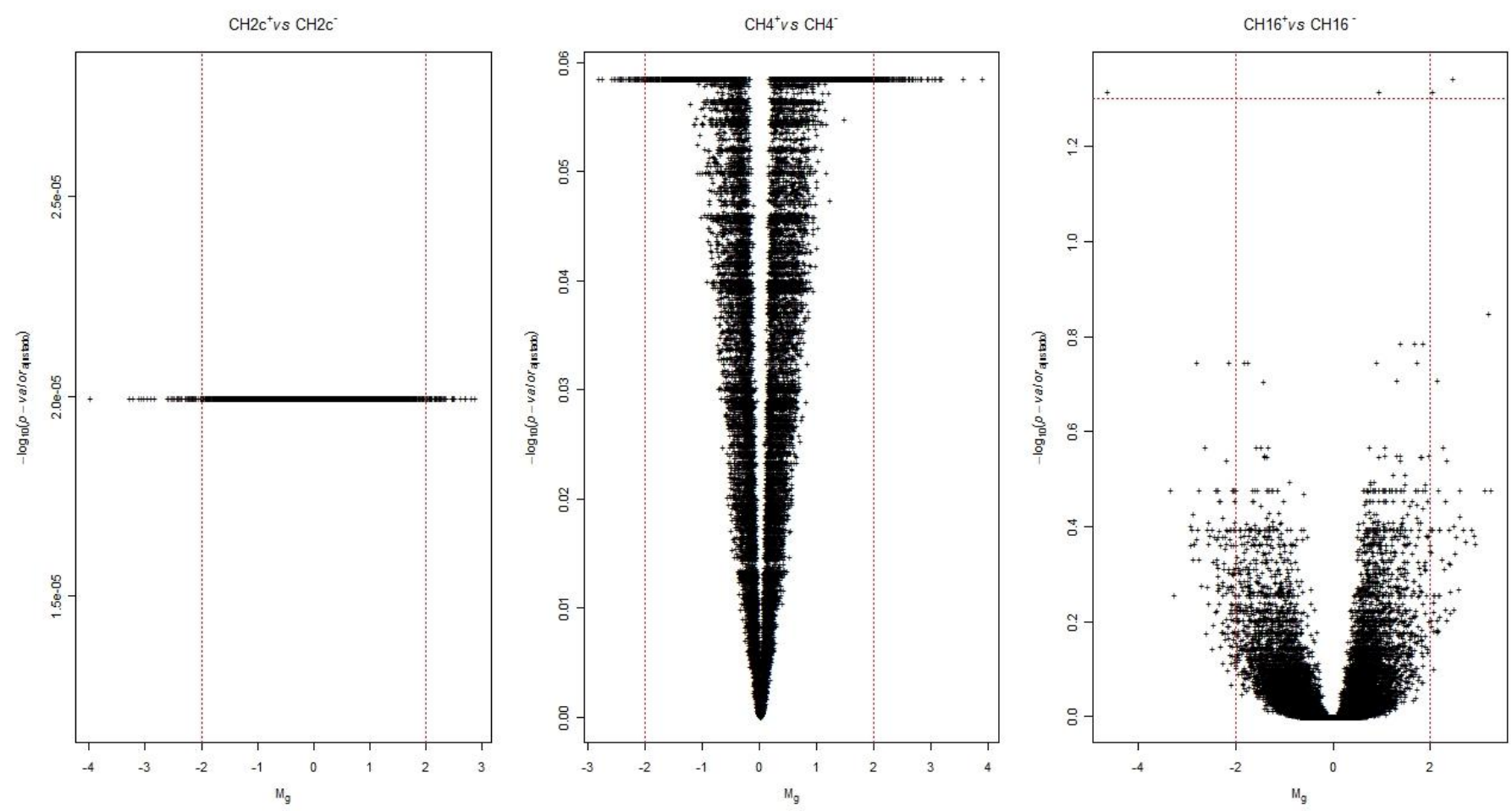

Figura 22. Gráfico vulcão para as hipóteses $H_{0}: \mu_{C H 2 c}^{+}-\mu_{C H 2 c}^{-}=0$ (à esquerda), $H_{0}: \mu_{C H 4}^{+}-\mu_{C H 4}^{-}=0$ (central) e $H_{0}: \mu_{C H 16}^{+}-\mu_{C H 16}^{-}=0$ (à direita).

Para fornecer ao pesquisador de fato as informações de interesse, como o código ou nome do fragmento genético classificado como DE, foi elaborado um programa no Microsoft Excel para gerar listas de genes DE. Uma listagem contendo os fragmentos genéticos DE está apresentada na Tabela 7.

Tabela 5. Listagem dos fragmentos genéticos DE.

\begin{tabular}{llc}
\hline Contraste & Fragmento & Quadrante \\
\hline$S H R^{+}-C H 2 a^{+}$ & GE16269 & D \\
$S H R^{+}-C H 2 c^{+}$ & GE18021 & E \\
$S H R^{+}-C H 2 c^{+}$ & GE17089 & D \\
$S H R^{+}-C H 2 c^{+}$ & GE1275619 & D \\
$S H R^{+}-C H 4^{+}$ & GE1153031 & E \\
$S H R^{+}-C H 4^{+}$ & GE12617 & E \\
$S H R^{+}-C H 4^{+}$ & GE13974 & E \\
$S H R^{+}-C H 4^{+}$ & GE14452 & E \\
$S H R^{+}-C H 4^{+}$ & GE1279991 & E \\
$S H R^{+}-C H 4^{+}$ & GE13778 & E \\
$S H R^{+}-C H 4^{+}$ & GE1190026 & E
\end{tabular}




\begin{tabular}{lll}
$S H R^{+}-C H 4^{+}$ & GE17444 & E \\
$S H R^{+}-C H 4^{+}$ & GE14544 & E \\
$S H R^{+}-C H 4^{+}$ & GE1232331 & E \\
$S H R^{+}-C H 4^{+}$ & GE1155846 & E \\
$S H R^{+}-C H 4^{+}$ & GE1238638 & D \\
$S H R^{+}-C H 4^{+}$ & GE14422 & D \\
$S H R^{+}-C H 4^{+}$ & GE1162596 & D \\
$S H R^{+}-C H 16^{+}$ & GE1301531 & E \\
$S H R^{+}-C H 16^{+}$ & GE17320 & D \\
$S H R^{-}-C H 2 a^{-}$ & GE16269 & D \\
$S H R^{-}-C H 2 c^{-}$ & GE18021 & E \\
$S H R^{-}-C H 2 c^{-}$ & GE1284198 & E \\
$S H R^{-}-C H 2 c^{-}$ & GE20039 & E \\
$S H R^{-}-C H 2 c^{-}$ & GE17089 & D \\
$S H R^{-}-C H 2 c^{-}$ & GE1212975 & D \\
$S H R^{-}-C H 2 c^{-}$ & GE1275619 & D \\
$S H R^{-}-C H 4^{-}$ & GE1153031 & E \\
$S H R^{-}-C H 4^{-}$ & GE13974 & E \\
$S H R^{-}-C H 4^{-}$ & GE14452 & E \\
$S H R^{-}-C H 4^{-}$ & GE1190026 & E \\
$S H R^{-}-C H 4^{-}$ & GE14544 & E \\
$S H R^{-}-C H 4^{-}$ & GE13778 & E \\
$S H R^{-}-C H 4^{-}$ & GE17444 & E \\
$S H R^{-}-C H 4^{-}$ & GE1238638 & D \\
$S H R^{-}-C H 4^{-}$ & GE14422 & D \\
$S H R^{-}-C H 4^{-}$ & GE1162596 & D \\
$S H R^{-}-C H 16^{-}$ & GE17320 & D \\
$C H 16^{+}-C H 16^{-}$ & GE1120119 & E \\
$C H 16^{+}-C H 16^{-}$ & GE1202435 & D \\
$C H 16^{+}-C H 16^{-}$ & GE17753 & D \\
\hline & &
\end{tabular}

Com base na lista de genes DE o próximo passo é levantar a documentação de cada fragmento cromossômico, identificando a sua localização no genoma do rato, sua composição em bases nitrogenadas, se já foi associado a fenótipos cardiovasculares por outros estudos, etc. Estudos qualitativos desta natureza servem para validar os encontros da análise estatística. 


\subsection{Aplicação da TRI}

Iniciando a contextualização da TRI à Microarrays deve ser lembrado que a base de dados disponibilizada pelo InCor foi obtida por meio do delineamento fatorial já apresentado, do qual, com a utilização de 50 arrays, se realizou a coleta dos valores de expressão gênica dos 35.129 fragmentos genéticos presentes em cada uma das 50 amostras biológicas que representaram os 50 ratos de diferentes linhagens submetidos a distintas condições experimentais. Desta forma, como o objetivo ao se analisar a base de dados está associado à identificação daqueles fragmentos genéticos $\mathrm{DE}$, a primeira contextualização da TRI a Microarrays é marcada pelo modo com o qual se visualizará daqui em diante os fragmentos genéticos e as combinações entre linhagens e condições experimentais. Contudo, a contextualização mais importante diz respeito à definição da variável latente, a qual neste estudo representa os valores de expressão gênica.

Assim sendo, nas formulações da TRI utilizadas neste trabalho, as diferentes combinações entre linhagens, condições experimentais e réplicas (ver Figura 1) são consideradas como "Itens" e os 35.129 fragmentos genéticos avaliados em cada uma destas combinações devem ser considerados como "Indivíduos". Sob esta colocação, ao se ajustar um modelo da TRI se torna possível predizer para cada fragmento genético a sua variável latente que está associada à predisposição com a qual este se expressa. Por consequiência, a partir desta variável latente predita se pode calcular a probabilidade de cada fragmento genético estar expresso em cada uma das condições experimentais. Este resultado certamente vem de encontro aos objetivos dos pesquisadores da área, pois por meio das probabilidades estimadas é possível selecionar os fragmentos genéticos mais prováveis de estarem expressos em cada item (condição experimental). Além disso, como será discutido em maiores detalhes, também se torna possível, a partir dos valores estimados para os parâmetros que representam os itens, posicionar os itens na escala construída, fato este que possibilitará aos pesquisadores saber em quais itens se terá menor ou maior probabilidade de se encontrar fragmentos genéticos expressos.

Uma vez que para os modelos da TRI se faz necessário categorizar os valores de expressão gênica, inicialmente, se optou por explorar algumas análises descritivas sob a base de dados categorizadas para, posteriormente, formalizar os modelos e apresentar os resultados obtidos. 
O primeiro critério de categorização adotado consistiu em considerar os valores de expressão gênica normalizados $\left(y_{i g}\right)$ e classificá-los da seguinte forma,

$$
y^{*}{ }_{i g}= \begin{cases}0 & \text { se } y_{i g} \leq Q_{3} \\ 1 & \text { se } y_{i g}>Q_{3 i}\end{cases}
$$

com $i=1, \ldots, 50$ e $Q_{3 i}$ representando o valor do percentil 75 do $i$ - ésimo item.

A escolha do valor $Q_{3}$ para classificar um particular fragmento genético como expresso (ter alto valor de expressão gênica) ou não expresso está no fato de se esperar a priori que, do ponto de vista biológico, muitos dos fragmentos genéticos avaliados em uma amostra não devam apresentar valores de expressão gênica tão elevados.

Após aplicar este critério de categorização é possível calcular, para todos os 35.129 fragmentos genéticos, a estatística descritiva $S_{g}=\sum_{g=1}^{50} y^{*}{ }_{i g}$ que representa o total de vezes em que o $g$ - ésimo fragmento genético foi classificado como $y^{*}{ }_{i g}=1$ sob os 50 itens (escore do $g$ - ésimo fragmento genético). Após calcular a estatística $S_{g}$ para cada um dos $G$ fragmentos genéticos, é possível construir a distribuição de freqüência desta estatística, a qual pode ser visualizada na Figura 23. 


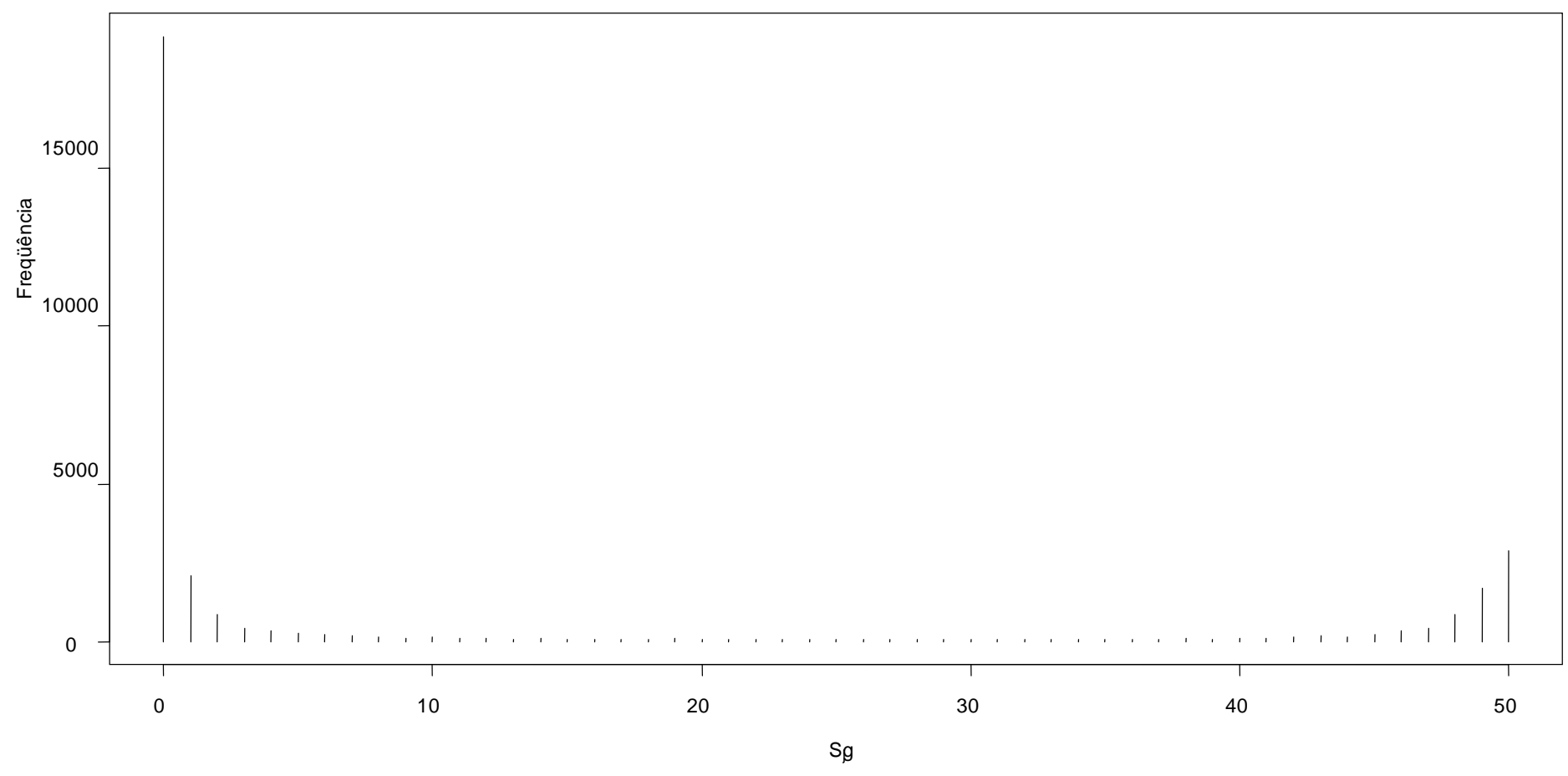

Figura 23. Distribuição de frequiência do escore $S_{g}$ dos $G$ fragmentos genéticos avaliados.

Esta distribuição é importante quando utilizadas metodologias de estimação clássica, pois, como enfatizado no capítulo anterior, quando para um item todos ou nenhum indivíduo responde corretamente, se terá problemas para estimar os parâmetros que caracterizam este item. Desta forma, dado o elevado número de fragmentos genéticos expressos em todas (2.895) ou em nenhuma (19.127) condição experimental, se optou por conduzir a análise sem a presença destes. Também se optou por excluir da análise aqueles fragmentos genéticos com pelo menos uma perda de informação (1.543) sob os 50 itens, havendo assim a redução de 35.129 para 11.564 fragmentos genéticos considerados no estágio de modelagem.

Após esta decisão, por exemplo, o percentual de fragmentos genéticos expressos nos itens de 1 a 10 pode ser observado na Tabela 6 . 
Tabela 6. Percentual de fragmentos genéticos expressos e não expressos nos itens 1 a 10 (condições experimentais Bloco 1).

\begin{tabular}{lcc}
\hline & \multicolumn{2}{c}{ Percentual de } \\
\cline { 2 - 3 } Item & Não expresso $\left(y^{*}{ }_{i g}=0\right)$ & Expresso $\left(y^{*}{ }_{i g}=1\right)$ \\
\hline$I_{1}\left(\mathrm{SHR}^{+}\right)$ & $52,59 \%$ & $47,41 \%$ \\
$I_{2}\left(\mathrm{CH} 2 \mathrm{a}^{+}\right)$ & $52,41 \%$ & $47,59 \%$ \\
$I_{3}\left(\mathrm{CH} 2 \mathrm{c}^{+}\right)$ & $52,31 \%$ & $47,69 \%$ \\
$I_{4}\left(\mathrm{CH} 4^{+}\right)$ & $52,16 \%$ & $47,84 \%$ \\
$I_{5}\left(\mathrm{CH} 16^{+}\right)$ & $52,08 \%$ & $47,92 \%$ \\
$I_{6}\left(\mathrm{SHR} \mathrm{R}^{-}\right)$ & $52,26 \%$ & $47,74 \%$ \\
$I_{7}\left(\mathrm{CH} 2 \mathrm{a}^{-}\right)$ & $52,38 \%$ & $47,62 \%$ \\
$I_{8}\left(\mathrm{CH} 2 \mathrm{c}^{-}\right)$ & $52,20 \%$ & $47,80 \%$ \\
$I_{9}\left(\mathrm{CH} 4^{-}\right)$ & $52,11 \%$ & $47,89 \%$ \\
$I_{10}\left(\mathrm{CH} 16^{-}\right)$ & $52,37 \%$ & $47,63 \%$ \\
\hline
\end{tabular}

A partir da Tabela 6 se observa que estes percentuais são muito próximos para todos os itens, o que pode ser um indício de que as chances de um fragmento estar ou não expresso nos diferentes itens são próximas.

Prosseguindo com a análise, de modo a estimar os parâmetros dos 50 itens e as variáveis latentes dos 11.564 fragmentos genéticos, com a utilização do aplicativo $\mathrm{R}$ (versão 2.7.2), em particular o uso do pacote tlm (Latent Trait Models), se fez o ajuste do modelo ML2 apresentado em (4.2.2.2), se obtendo as estimativas apresentadas na Tabela 7.

Tabela 7. Estimativas dos parâmetros do ML2.

\begin{tabular}{lcccc}
\hline \multirow{2}{*}{ Item } & \multicolumn{4}{c}{ Parâmetros } \\
\cline { 2 - 5 } & $\begin{array}{c}\text { Dificuldade } \\
\left(b_{i}\right)\end{array}$ & $\begin{array}{c}\text { Erro padrão } \\
\left(b_{i}\right)\end{array}$ & $\begin{array}{c}\text { Discriminação } \\
\left(a_{i}\right)\end{array}$ & $\begin{array}{c}\text { Erro padrão } \\
\left(a_{i}\right)\end{array}$ \\
\hline$I_{1}\left(\mathrm{SHR}^{+}\right)$ & 0,1810 & 0,0398 & 0,5053 & 0,0162 \\
$I_{2}\left(\mathrm{CH} 2 \mathrm{a}^{+}\right)$ & 0,1004 & 0,0271 & 0,7984 & 0,0186 \\
$I_{3}\left(\mathrm{CH} 2 \mathrm{c}^{+}\right)$ & 0,0528 & 0,0197 & 1,2729 & 0,0241 \\
$I_{4}\left(\mathrm{CH}^{+}\right)$ & 0,0247 & 0,0164 & 1,7802 & 0,0321
\end{tabular}




\begin{tabular}{|c|c|c|c|c|}
\hline$I_{5}\left(\mathrm{CH} 16^{+}\right)$ & 0,0248 & 0,0170 & 1,6625 & 0,0301 \\
\hline$I_{6}\left(S H R^{-}\right)$ & 0,0176 & 0,0148 & 2,2460 & 0,0412 \\
\hline$I_{7}\left(\mathrm{CH}_{2} a^{-}\right)$ & 0,0272 & 0,0154 & 2,0618 & 0,0372 \\
\hline$I_{8}\left(\mathrm{CH}_{2 c^{-}}\right)$ & 0,0200 & 0,0155 & 2,0140 & 0,0363 \\
\hline$I_{9}\left(\mathrm{CH}_{4}^{-}\right)$ & 0,0049 & 0,0140 & 2,5802 & 0,0486 \\
\hline$I_{10}\left(\mathrm{CH}_{16} 6^{-}\right)$ & 0,0190 & 0,0143 & 2,4490 & 0,0457 \\
\hline$I_{11}\left(S_{H R}^{+}\right)$ & 0,0041 & 0,0120 & 3,8752 & 0,0887 \\
\hline$I_{12}\left(C H 2 a^{+}\right)$ & 0,0051 & 0,0121 & 3,7827 & 0,0853 \\
\hline$I_{13}\left(\mathrm{CH}_{2 c^{+}}\right)$ & 0,0071 & 0,0128 & 3,2589 & 0,0675 \\
\hline$I_{14}\left(\mathrm{CH}^{+}\right)$ & 0,0043 & 0,0133 & 2,9901 & 0,0597 \\
\hline$I_{15}\left(\mathrm{CH} 16^{+}\right)$ & 0,0071 & 0,0129 & 3,2190 & 0,0663 \\
\hline$I_{16}\left(S H R^{-}\right)$ & 0,0140 & 0,0145 & 2,3928 & 0,0445 \\
\hline$I_{17}\left(C H 2 a^{-}\right)$ & 0,0135 & 0,0142 & 2,5150 & 0,0474 \\
\hline$I_{18}\left(C H 2 c^{-}\right)$ & 0,0092 & 0,0140 & 2,5886 & 0,0491 \\
\hline$I_{19}\left(\mathrm{CH}^{-}\right)$ & 0,0157 & 0,0150 & 2,1841 & 0,0399 \\
\hline$I_{20}\left(\mathrm{CH}_{16} 6^{-}\right)$ & 0,0670 & 0,0241 & 0,9298 & 0,0200 \\
\hline$I_{21}\left(S H R^{+}\right)$ & 0,0022 & 0,0117 & 4,0705 & 0,0960 \\
\hline$I_{22}\left(\mathrm{CH}_{2} \mathrm{a}^{+}\right)$ & 0,0074 & 0,0129 & 3,1890 & 0,0663 \\
\hline$I_{23}\left(\mathrm{CH}_{2} \mathrm{c}^{+}\right)$ & 0,0025 & 0,0119 & 3,9509 & 0,0916 \\
\hline $\mathrm{I}_{24}\left(\mathrm{CH}^{+}\right)$ & $-0,0009$ & 0,0122 & 3,7186 & 0,0820 \\
\hline$I_{25}\left(C H 16^{+}\right)$ & 0,0237 & 0,0148 & 2,2633 & 0,0419 \\
\hline$I_{26}\left(S H R^{-}\right)$ & 0,0001 & 0,0117 & 4,0953 & 0,0969 \\
\hline$I_{27}\left(\mathrm{CH}_{2} a^{-}\right)$ & 0,0018 & 0,0121 & 3,8006 & 0,0857 \\
\hline$I_{28}\left(C H 2 c^{-}\right)$ & 0,0008 & 0,0117 & 4,1183 & 0,0983 \\
\hline $\mathrm{I}_{29}\left(\mathrm{CH}_{4}^{-}\right)$ & 0,0017 & 0,0111 & 4,5427 & 0,1160 \\
\hline$I_{30}\left(\mathrm{CH}_{16} 6^{-}\right)$ & 0,0048 & 0,0126 & 3,3825 & 0,0713 \\
\hline$I_{31}\left(S H R^{+}\right)$ & 0,0019 & 0,0111 & 4,5986 & 0,1175 \\
\hline$I_{32}\left(\mathrm{CH}_{2} \mathrm{a}^{+}\right)$ & $-0,0035$ & 0,0092 & 6,2674 & 0,2197 \\
\hline$I_{33}\left(\mathrm{CH}_{2} \mathrm{c}^{+}\right)$ & $-0,0039$ & 0,0110 & 4,6893 & 0,1228 \\
\hline$I_{34}\left(\mathrm{CH}_{4}^{+}\right)$ & $-1,0518$ & 0,2449 & $-0,0967$ & 0,0145 \\
\hline$I_{35}\left(\mathrm{CH} 16^{+}\right)$ & $-0,0060$ & 0,0105 & 5,0624 & 0,1421 \\
\hline$I_{36}\left(S H R^{-}\right)$ & $-0,0021$ & 0,0112 & 4,5235 & 0,1148 \\
\hline$I_{37}\left(\mathrm{CH}_{2} \mathrm{a}^{-}\right)$ & $-0,0023$ & 0,0110 & 4,6985 & 0,1226 \\
\hline$I_{38}\left(C H 2 c^{-}\right)$ & $-0,0006$ & 0,0129 & 3,1900 & 0,0656 \\
\hline $\mathrm{I}_{39}\left(\mathrm{CH}_{4}^{-}\right)$ & $-0,0081$ & 0,0119 & 3,9260 & 0,0896 \\
\hline$I_{40}\left(\mathrm{CH}_{16} 6^{-}\right)$ & 0,0117 & 0,0148 & 2,2628 & 0,0416 \\
\hline$I_{41}\left(S H R^{+}\right)$ & 0,0060 & 0,0119 & 3,9480 & 0,0908 \\
\hline$I_{42}\left(\mathrm{CH}_{2} \mathrm{a}^{+}\right)$ & 0,0035 & 0,0118 & 3,9830 & 0,0932 \\
\hline$I_{43}\left(\mathrm{CH}_{2} \mathrm{c}^{+}\right)$ & 0,0000 & 0,0117 & 4,1087 & 0,0978 \\
\hline $\mathrm{I}_{44}\left(\mathrm{CH}_{4}^{+}\right)$ & 0,0029 & 0,0118 & 4,0144 & 0,0935 \\
\hline$I_{45}\left(\mathrm{CH} 16^{+}\right)$ & 0,0055 & 0,0126 & 3,3990 & 0,0720 \\
\hline$I_{46}\left(S H R^{-}\right)$ & 0,0050 & 0,0125 & 3,5028 & 0,0759 \\
\hline$I_{47}\left(\mathrm{CH}_{2} a^{-}\right)$ & 0,0028 & 0,0123 & 3,6511 & 0,0808 \\
\hline$I_{48}\left(\mathrm{CH}_{2} \mathrm{c}^{-}\right)$ & $-0,0037$ & 0,0120 & 3,8407 & 0,0875 \\
\hline
\end{tabular}




\begin{tabular}{lllll}
$I_{49}\left(\mathrm{CH}^{-}\right)$ & 0,0111 & 0,0140 & 2,5695 & 0,0490 \\
$I_{50}\left(\mathrm{CH} 16^{-}\right)$ & 0,0155 & 0,0151 & 2,1388 & 0,0392 \\
\hline
\end{tabular}

Os resultados apresentados na Tabela 7 trazem indícios de problemas com o item $\mathrm{I}_{34}\left(\mathrm{CH}^{+}\right)$, uma vez que sob o modelo (4.2.2.2) não se espera valores negativos para os parâmetros de discriminação, como evidenciado para este item $\left(a_{i}=\right.$ -0,0967), problema este que pode ser decorrente de se utilizar um processo de estimação baseado na função de verossimilhança marginal. Sendo assim, frente a esta colocação, desconsiderando o item $\mathrm{I}_{34}\left(\mathrm{CH}^{+}\right)$, se obteve as estimativas apresentadas na Tabela 8.

Tabela 8. Estimativa dos parâmetros do ML2 desconsiderando $\mathrm{I}_{34}\left(\mathrm{CH} 4^{+}\right)$.

\begin{tabular}{lcccc}
\hline \multirow{2}{*}{ Item } & \multicolumn{4}{c}{ Parâmetros } \\
\cline { 2 - 5 } & $\begin{array}{c}\text { Dificuldade } \\
\left(b_{i}\right)\end{array}$ & $\begin{array}{c}\text { Erro padrão } \\
\left(b_{i}\right)\end{array}$ & $\begin{array}{c}\text { Discriminação } \\
\left(a_{i}\right)\end{array}$ & $\begin{array}{c}\text { Erro padrão } \\
\left(a_{i}\right)\end{array}$ \\
\hline$I_{1}\left(S H R^{+}\right)$ & 0,1817 & 0,0399 & 0,5033 & 0,0162 \\
$I_{2}\left(C H 2 a^{+}\right)$ & 0,1001 & 0,0271 & 0,7966 & 0,0185 \\
$I_{3}\left(C H 2 c^{+}\right)$ & 0,0522 & 0,0197 & 1,2707 & 0,0240 \\
$I_{4}\left(C H 4^{+}\right)$ & 0,0245 & 0,0164 & 1,7778 & 0,0321 \\
$I_{5}\left(C H 16^{+}\right)$ & 0,0245 & 0,0170 & 1,6604 & 0,0300 \\
$I_{6}\left(S H R^{-}\right)$ & 0,0174 & 0,0148 & 2,2430 & 0,0411 \\
$I_{7}\left(C H 2 a^{-}\right)$ & 0,0271 & 0,0154 & 2,0593 & 0,0372 \\
$I_{8}\left(C H 2 c^{-}\right)$ & 0,0198 & 0,0155 & 2,0118 & 0,0363 \\
$I_{9}\left(C H 4^{-}\right)$ & 0,0046 & 0,0140 & 2,5767 & 0,0485 \\
$I_{10}\left(C H 16^{-}\right)$ & 0,0188 & 0,0143 & 2,4454 & 0,0456 \\
\hline$I_{11}\left(S H R^{+}\right)$ & 0,0037 & 0,0120 & 3,8682 & 0,0884 \\
$I_{12}\left(C H 2 a^{+}\right)$ & 0,0047 & 0,0121 & 3,7774 & 0,0852 \\
$I_{13}\left(C H 2 c^{+}\right)$ & 0,0068 & 0,0128 & 3,2548 & 0,0674 \\
$I_{14}\left(C H 4^{+}\right)$ & 0,0040 & 0,0133 & 2,9863 & 0,0596 \\
$I_{15}\left(C H 16^{+}\right)$ & 0,0068 & 0,0129 & 3,2156 & 0,0662 \\
$I_{16}\left(S H R^{-}\right)$ & 0,0138 & 0,0145 & 2,3900 & 0,0444 \\
$I_{17}\left(C H 2 a^{-}\right)$ & 0,0133 & 0,0142 & 2,5125 & 0,0474 \\
$I_{18}\left(C H 2 c^{-}\right)$ & 0,0089 & 0,0140 & 2,5864 & 0,0491 \\
$I_{19}\left(C H 4^{-}\right)$ & 0,0155 & 0,0150 & 2,1822 & 0,0398 \\
$I_{20}\left(C H 16^{-}\right)$ & 0,0662 & 0,0241 & 0,9299 & 0,0200 \\
\hline$I_{21}\left(S H R^{+}\right)$ & 0,0018 & 0,0117 & 4,0651 & 0,0958 \\
$I_{22}\left(C H 2 a^{+}\right)$ & 0,0071 & 0,0129 & 3,1836 & 0,0661 \\
$I_{23}\left(C H 2 c^{+}\right)$ & 0,0021 & 0,0119 & 3,9438 & 0,0914 \\
& & & &
\end{tabular}




\begin{tabular}{|c|c|c|c|c|}
\hline $\mathrm{I}_{24}\left(\mathrm{CH}^{+}\right)$ & $-0,0013$ & 0,0122 & 3,7123 & 0,0818 \\
\hline$I_{25}\left(C H 16^{+}\right)$ & 0,0235 & 0,0148 & 2,2613 & 0,0418 \\
\hline$I_{26}\left(S H R^{-}\right)$ & $-0,0003$ & 0,0117 & 4,0911 & 0,0968 \\
\hline$I_{27}\left(\mathrm{CH}_{2} \mathrm{a}^{-}\right)$ & 0,0014 & 0,0121 & 3,7949 & 0,0855 \\
\hline$I_{28}\left(\mathrm{CH}_{2} \mathrm{c}^{-}\right)$ & 0,0004 & 0,0117 & 4,1184 & 0,0983 \\
\hline$I_{29}\left(\mathrm{CH}_{4}^{-}\right)$ & 0,0013 & 0,0112 & 4,5291 & 0,1154 \\
\hline$I_{30}\left(\mathrm{CH}_{16} 6^{-}\right)$ & 0,0045 & 0,0127 & 3,3786 & 0,0711 \\
\hline$I_{31}\left(S H R^{+}\right)$ & 0,0015 & 0,0111 & 4,5952 & 0,1174 \\
\hline$I_{32}\left(\mathrm{CH}_{2} \mathrm{a}^{+}\right)$ & $-0,0037$ & 0,0092 & 6,2458 & 0,2182 \\
\hline$I_{33}\left(\mathrm{CH}_{2} \mathrm{c}^{+}\right)$ & $-0,0042$ & 0,0110 & 4,6768 & 0,1223 \\
\hline $\mathrm{I}_{34}\left(\mathrm{CH}^{+}\right)$ & $-0,0063$ & 0,0106 & 5,0507 & 0,1416 \\
\hline$I_{35}\left(\mathrm{CH}_{16} 6^{+}\right)$ & $-0,0025$ & 0,0112 & 4,5086 & 0,1142 \\
\hline$I_{36}\left(S H R^{-}\right)$ & $-0,0027$ & 0,0110 & 4,6932 & 0,1224 \\
\hline$I_{37}\left(\mathrm{CH}_{2} \mathrm{a}^{-}\right)$ & $-0,0010$ & 0,0130 & 3,1856 & 0,0655 \\
\hline$I_{38}\left(\mathrm{CH}_{2} \mathrm{c}^{-}\right)$ & $-0,0085$ & 0,0120 & 3,9209 & 0,0895 \\
\hline$I_{39}\left(\mathrm{CH}^{-}\right)$ & 0,0115 & 0,0148 & 2,2600 & 0,0416 \\
\hline$I_{40}\left(\mathrm{CH}_{16} \mathrm{6}^{-}\right)$ & 0,0057 & 0,0119 & 3,9403 & 0,0906 \\
\hline$I_{41}\left(S H R^{+}\right)$ & 0,0031 & 0,0119 & 3,9713 & 0,0928 \\
\hline$I_{42}\left(C H 2 a^{+}\right)$ & $-0,0003$ & 0,0117 & 4,1000 & 0,0975 \\
\hline$I_{43}\left(\mathrm{CH}_{2} \mathrm{c}^{+}\right)$ & 0,0025 & 0,0118 & 4,0051 & 0,0931 \\
\hline$I_{44}\left(\mathrm{CH}^{+}\right)$ & 0,0051 & 0,0126 & 3,3941 & 0,0719 \\
\hline$I_{45}\left(\mathrm{CH}_{16} 6^{+}\right)$ & 0,0047 & 0,0125 & 3,4964 & 0,0757 \\
\hline$I_{46}\left(S H R^{-}\right)$ & 0,0024 & 0,0123 & 3,6442 & 0,0806 \\
\hline$I_{47}\left(\mathrm{CH}_{2} \mathrm{a}^{-}\right)$ & $-0,0040$ & 0,0120 & 3,8325 & 0,0872 \\
\hline$I_{48}\left(\mathrm{CH}_{2} \mathrm{c}^{-}\right)$ & 0,0108 & 0,0141 & 2,5649 & 0,0489 \\
\hline$I_{49}\left(\mathrm{CH}^{-}\right)$ & 0,0153 & 0,0151 & 2,1362 & 0,0391 \\
\hline$I_{50}\left(\mathrm{CH}_{16} 6^{-}\right)$ & 0,0155 & 0,0151 & 2,1388 & 0,0392 \\
\hline
\end{tabular}

Como já discutido, na TRI a interpretação dos parâmetros pode ser realizada com o auxílio das Curvas Características dos Itens - CCI, as quais são caracterizadas pelos parâmetros de dificuldade $\left(b_{i}\right)$ e discriminação $\left(a_{i}\right)$ estimados. Ainda, como auxílio na interpretação dos resultados, a Função de Informação do Item - FII e a Função de Informação do teste - FFT podem ser utilizadas. A seguir são apresentadas estas curvas e funções citadas acima para os itens estimados na Tabela 8. 

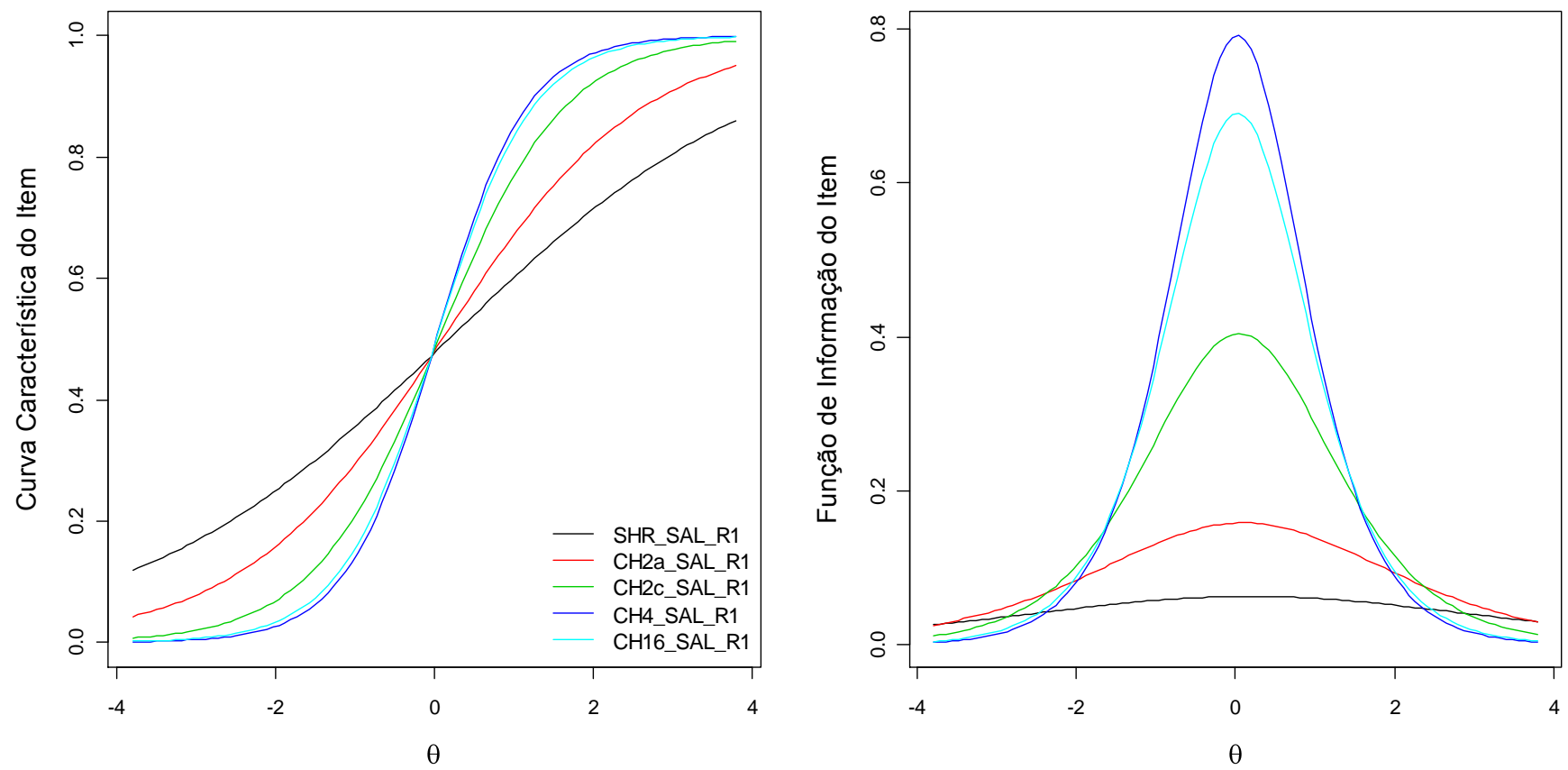

Figura 24. Curva Característica e Função de Informação dos Itens $I_{1}\left(\mathrm{SHR}^{+}\right)$, $\mathrm{I}_{2}\left(\mathrm{CH}_{2} \mathrm{a}^{+}\right), \mathrm{I}_{3}\left(\mathrm{CH} 2 \mathrm{c}^{+}\right), \mathrm{I}_{4}\left(\mathrm{CH}^{+}\right)$e $\mathrm{I}_{5}\left(\mathrm{CH} 16^{+}\right)$.
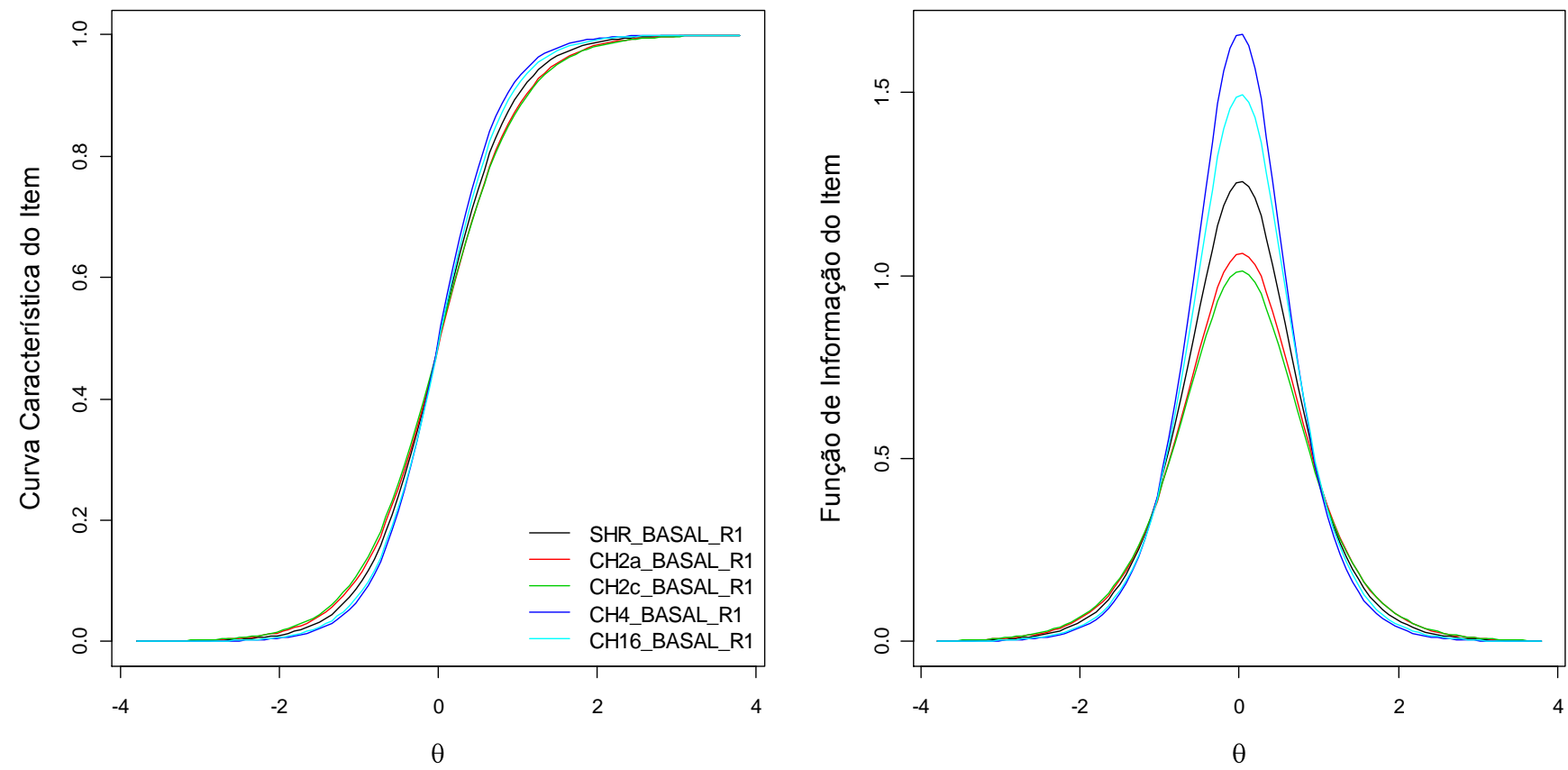

Figura 25. Curva Característica e Função de Informação dos Itens $\mathrm{I}_{6}\left(\mathrm{SHR}^{-}\right)$, $\mathrm{I}_{7}\left(\mathrm{CH} 2 \mathrm{a}^{-}\right), \mathrm{I}_{8}\left(\mathrm{CH} 2 \mathrm{c}^{-}\right), \mathrm{I}_{9}\left(\mathrm{CH} 4^{-}\right)$e $\mathrm{I}_{10}\left(\mathrm{CH} 16^{-}\right)$. 

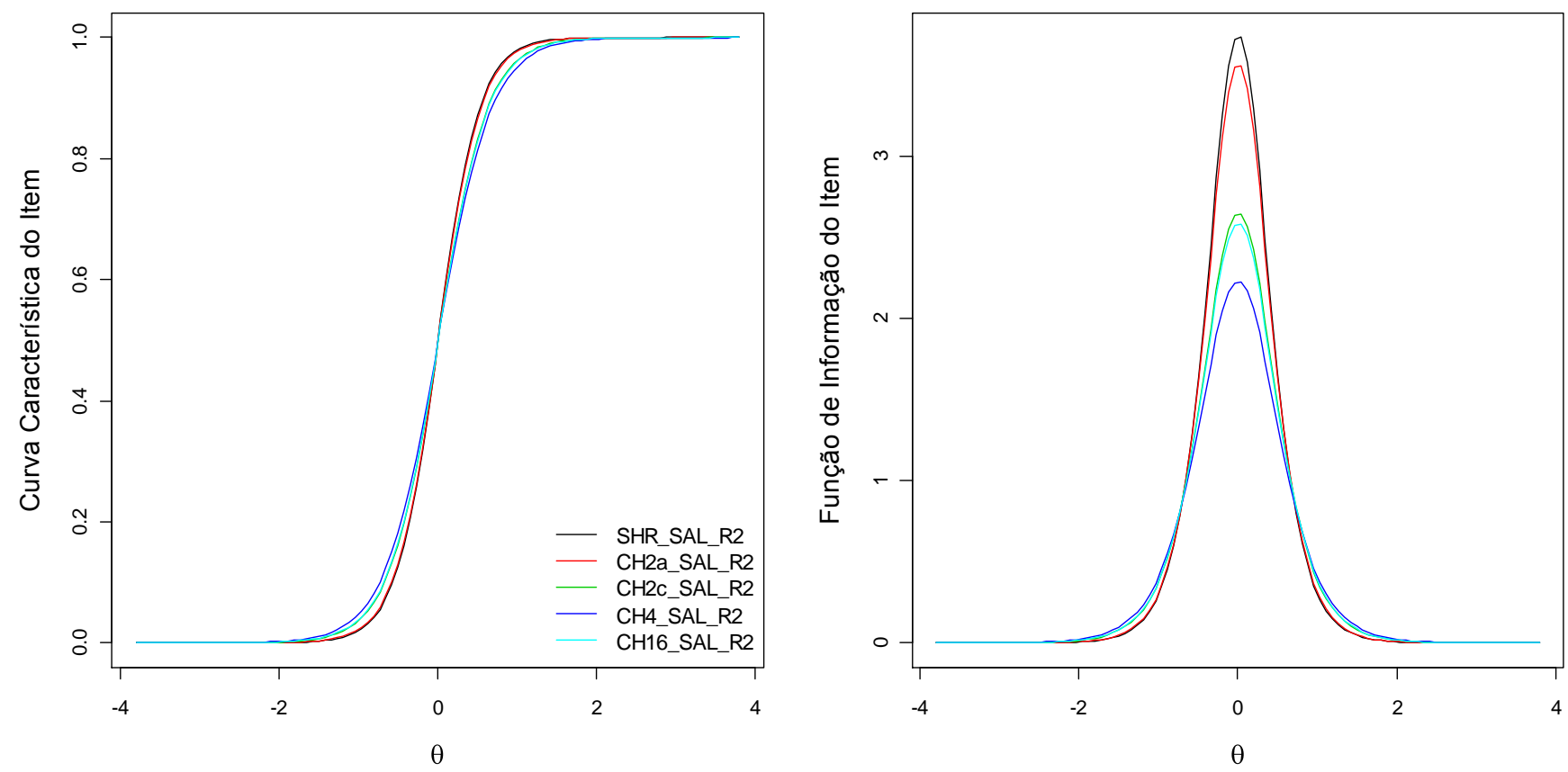

Figura 26. Curva Característica e Função de Informação dos Itens $\mathrm{I}_{11}\left(\mathrm{SHR}^{+}\right)$, $\mathrm{I}_{12}\left(\mathrm{CH} 2 \mathrm{a}^{+}\right), \mathrm{I}_{13}\left(\mathrm{CH} 2 \mathrm{c}^{+}\right), \mathrm{I}_{14}\left(\mathrm{CH}^{+}\right)$e $\mathrm{I}_{15}\left(\mathrm{CH} 16^{+}\right)$.
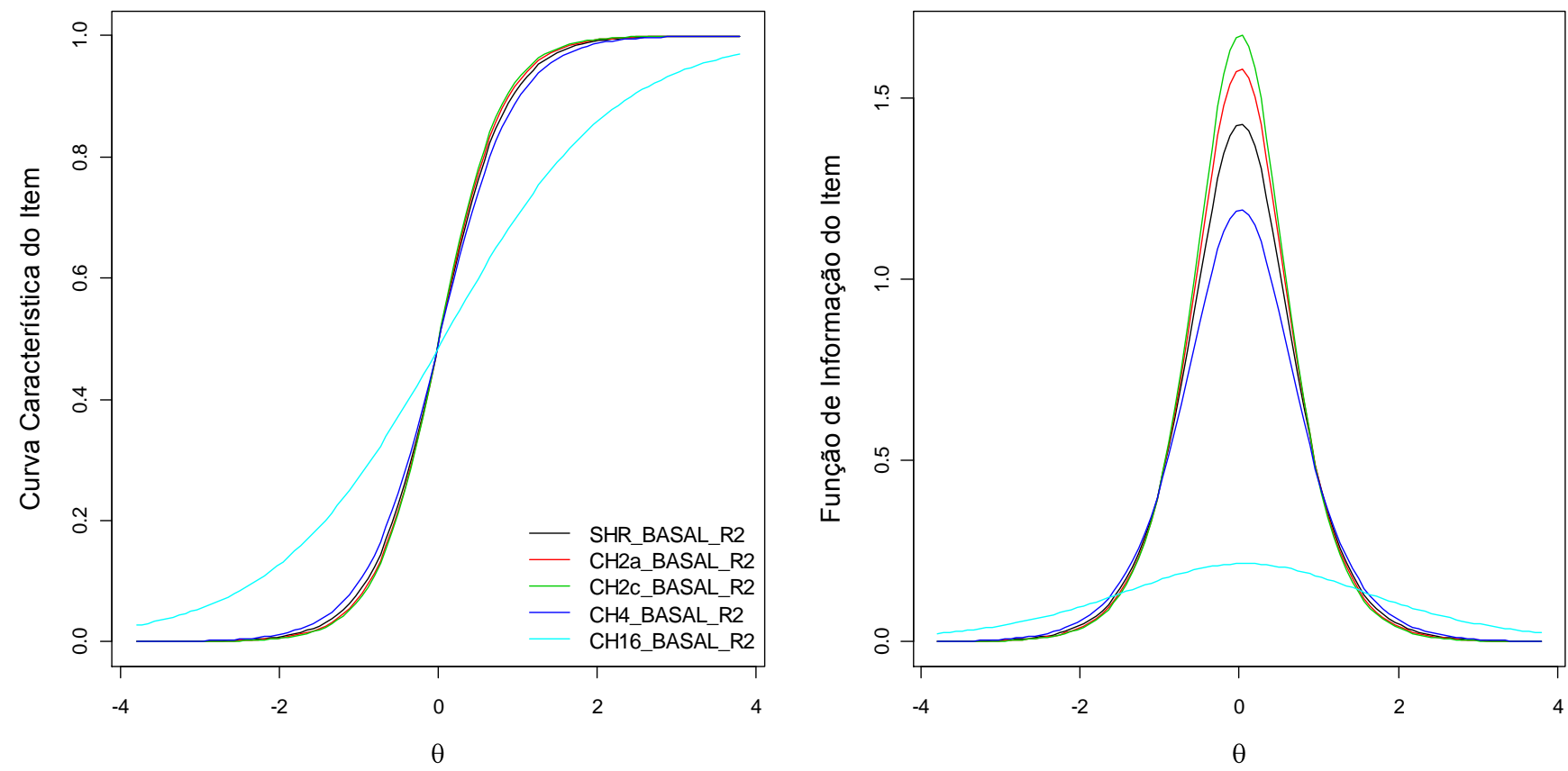

Figura 27. Curva Característica e Função de Informação dos Itens $\mathrm{I}_{16}\left(\mathrm{SHR}^{-}\right)$, $\mathrm{I}_{17}\left(\mathrm{CH} 2 \mathrm{a}^{-}\right), \mathrm{I}_{18}\left(\mathrm{CH} 2 \mathrm{c}^{-}\right), \mathrm{I}_{19}\left(\mathrm{CH}^{-}\right)$e $\mathrm{I}_{20}\left(\mathrm{CH} 16^{-}\right)$. 

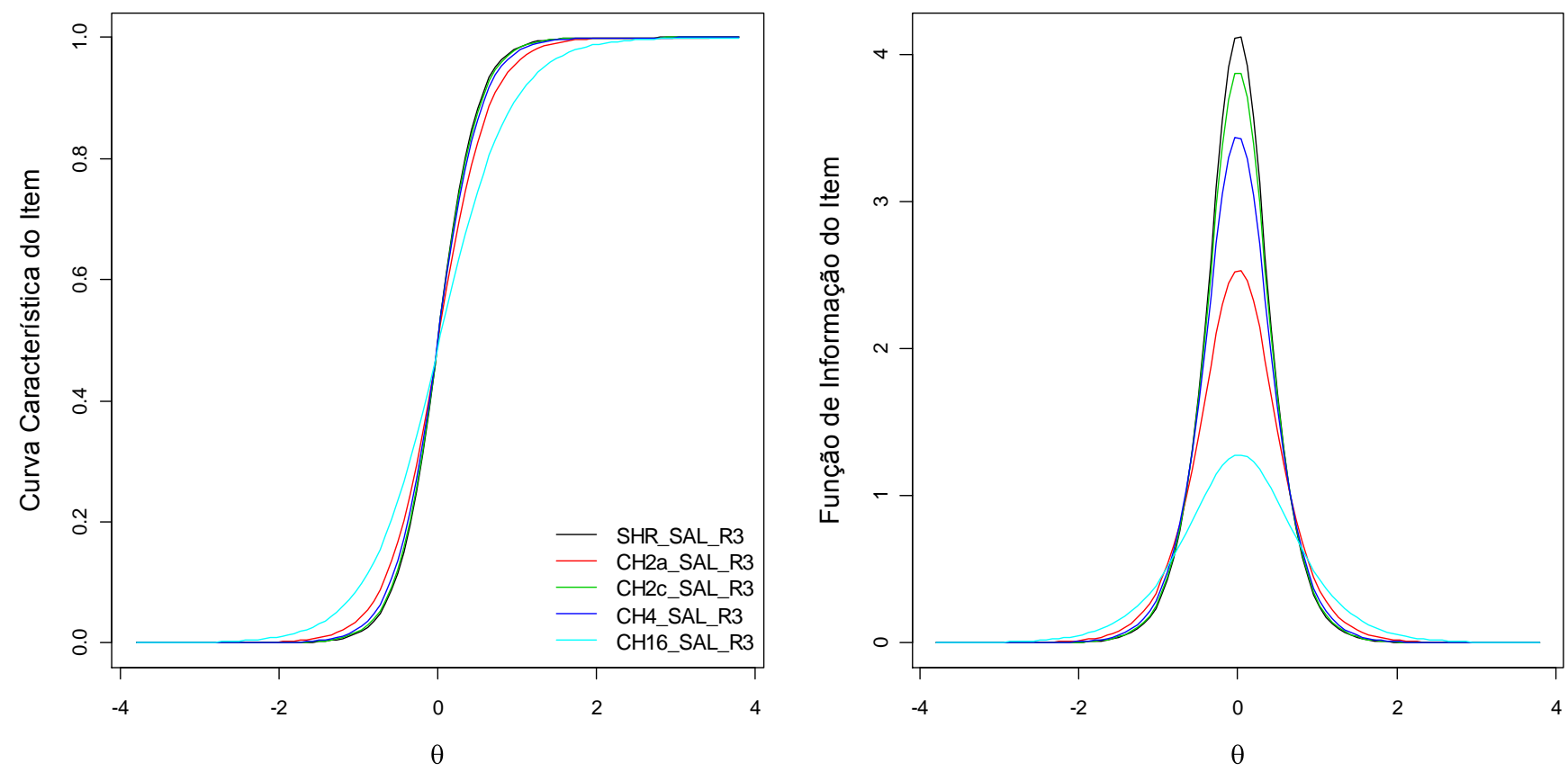

Figura 28. Curva Característica e Função de Informação dos Itens $I_{21}\left(\operatorname{SHR}^{+}\right)$, $\mathrm{I}_{22}\left(\mathrm{CH}_{2 \mathrm{a}^{+}}\right), \mathrm{I}_{23}\left(\mathrm{CH} 2 \mathrm{c}^{+}\right), \mathrm{I}_{24}\left(\mathrm{CH}^{+}\right)$e $\mathrm{I}_{25}\left(\mathrm{CH} 16^{+}\right)$.
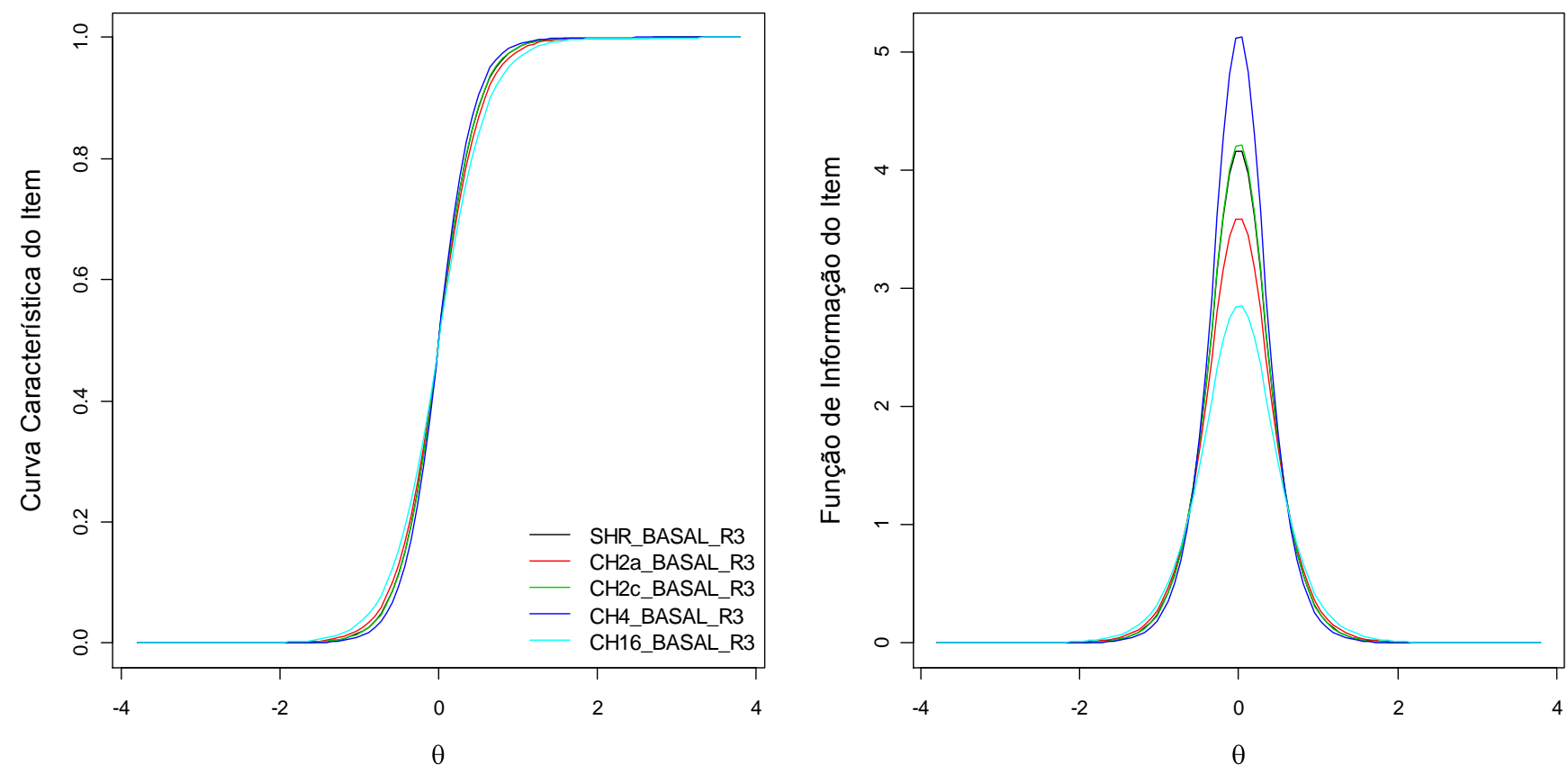

Figura 29. Curva Característica e Função de Informação dos Itens $\mathrm{I}_{26}\left(\mathrm{SHR}^{-}\right)$, $\mathrm{I}_{27}\left(\mathrm{CH} 2 \mathrm{a}^{-}\right), \mathrm{I}_{28}\left(\mathrm{CH}_{2} \mathrm{c}^{-}\right), \mathrm{I}_{29}\left(\mathrm{CH}^{-}\right)$e $\mathrm{I}_{30}\left(\mathrm{CH} 16^{-}\right)$. 

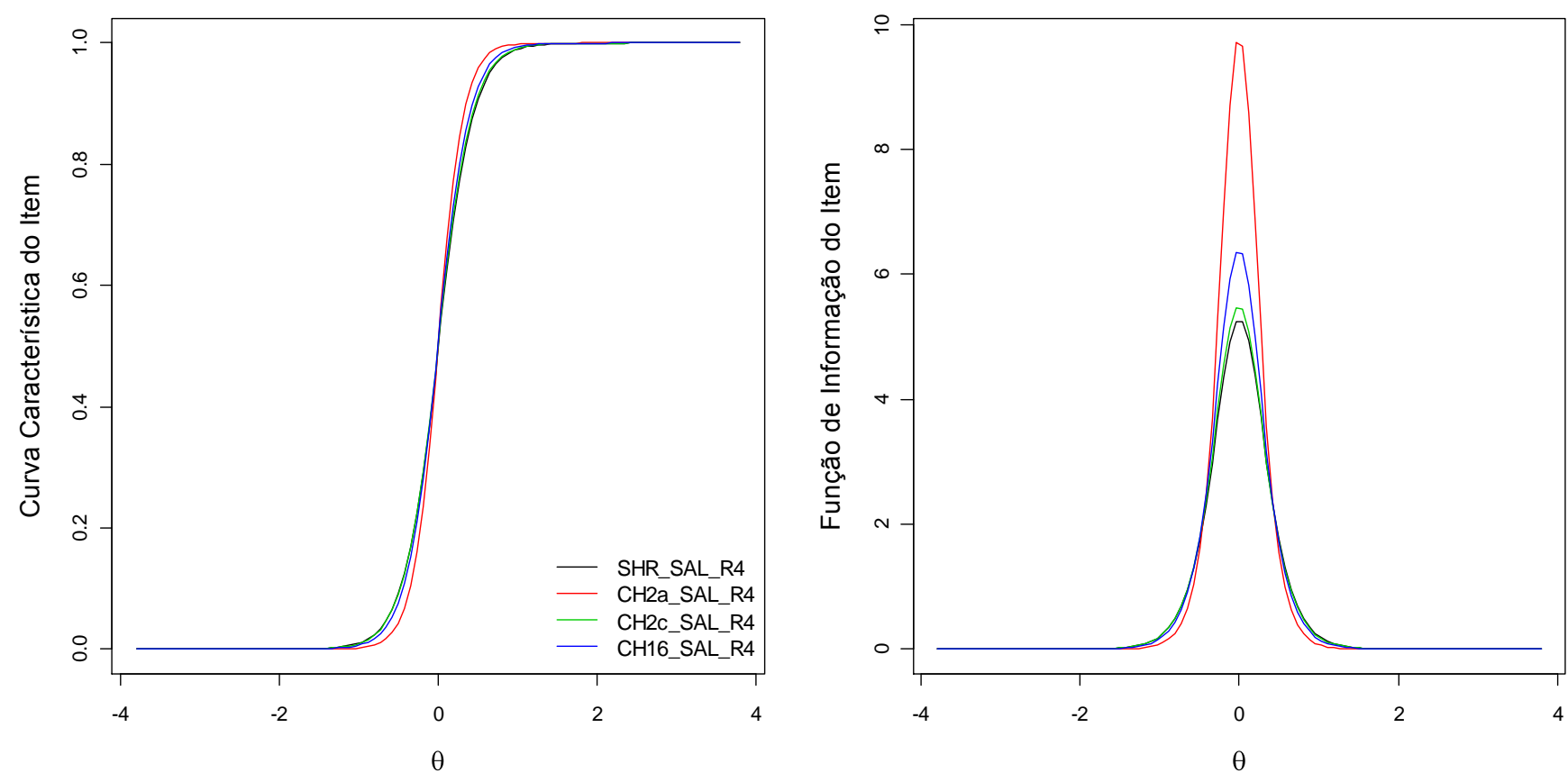

Figura 30. Curva Característica e Função de Informação dos Itens $I_{31}\left(\mathrm{SHR}^{+}\right)$, $\mathrm{I}_{32}\left(\mathrm{CH} 2 \mathrm{a}^{+}\right), \mathrm{I}_{33}\left(\mathrm{CH} 2 \mathrm{c}^{+}\right)$e $\mathrm{I}_{35}\left(\mathrm{CH} 16^{+}\right)$.
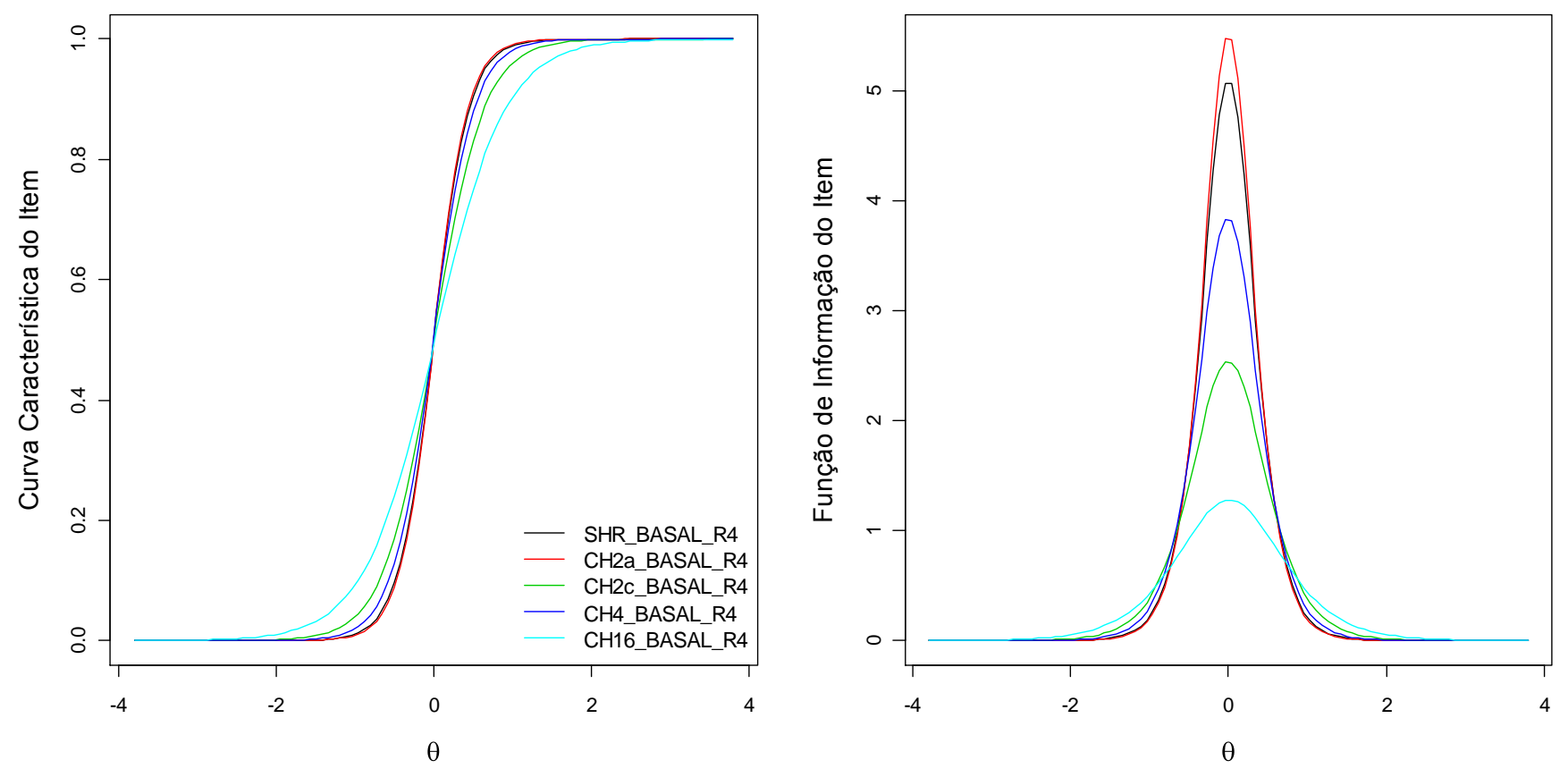

Figura 31. Curva Característica e Função de Informação dos Itens $I_{36}\left(\mathrm{SHR}^{-}\right)$, $\mathrm{I}_{37}\left(\mathrm{CH} 2 \mathrm{a}^{-}\right), \mathrm{I}_{38}\left(\mathrm{CH}_{2} \mathrm{c}^{-}\right), \mathrm{I}_{39}\left(\mathrm{CH}^{-}\right)$e $\mathrm{I}_{40}\left(\mathrm{CH} 16^{-}\right)$. 

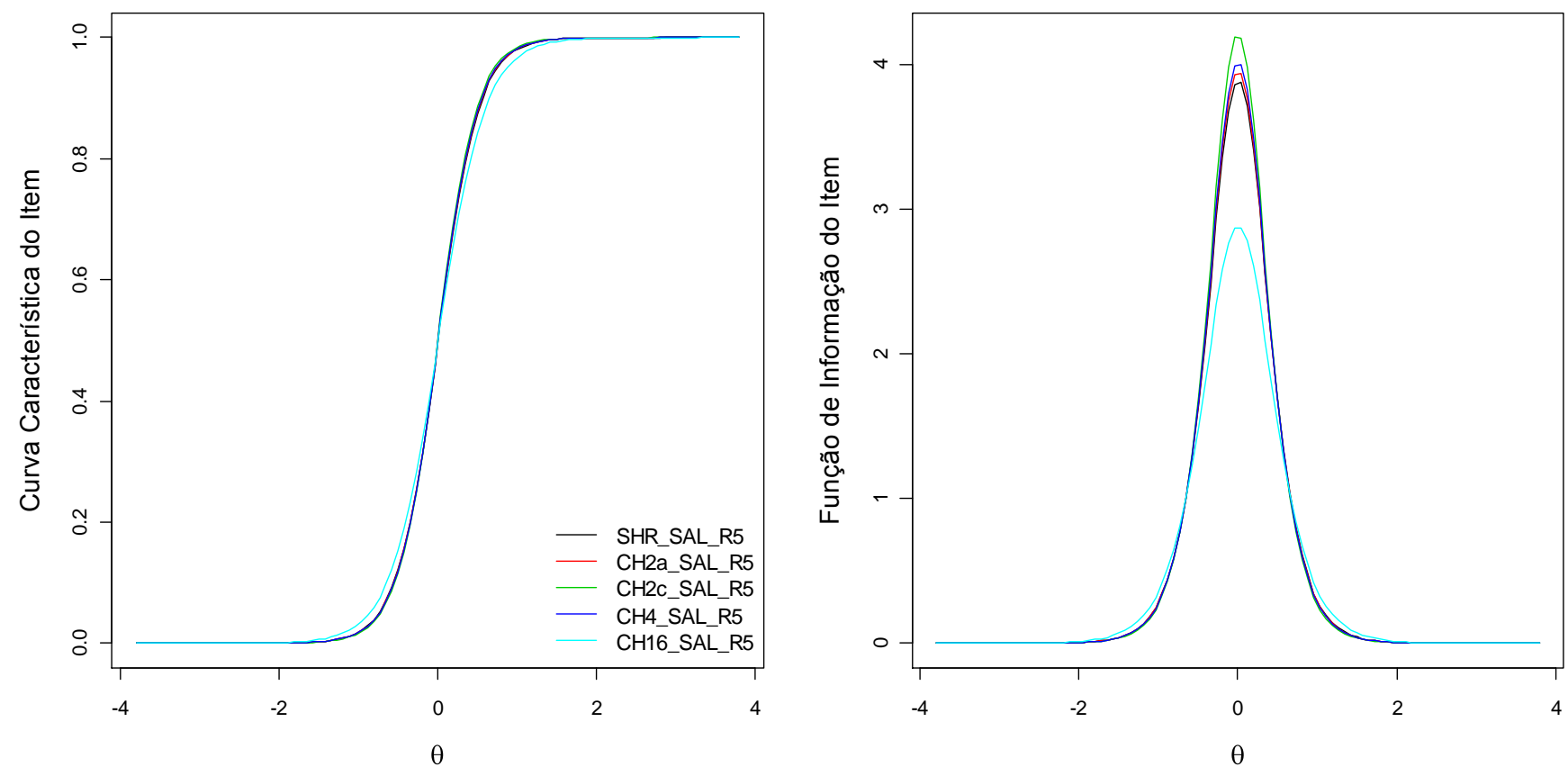

Figura 32. Curva Característica e Função de Informação dos Itens $\mathrm{I}_{41}\left(\mathrm{SHR}^{+}\right)$, $\mathrm{I}_{42}\left(\mathrm{CH}_{2} \mathrm{a}^{+}\right), \mathrm{I}_{43}\left(\mathrm{CH}_{2} \mathrm{c}^{+}\right), \mathrm{I}_{44}\left(\mathrm{CH}^{+}\right)$e $\mathrm{I}_{45}\left(\mathrm{CH} 16^{+}\right)$.
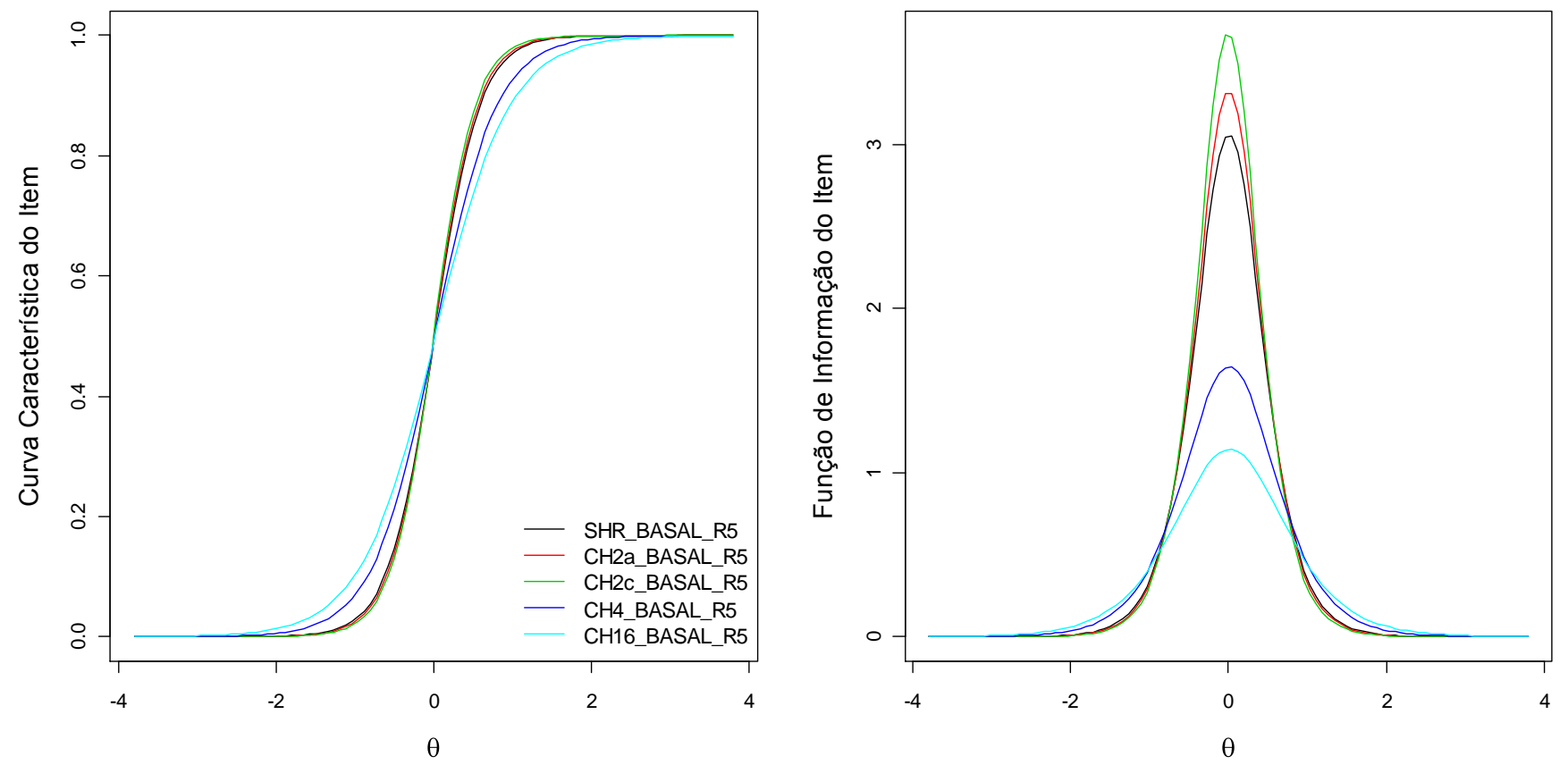

Figura 33. Curva Característica e Função de Informação dos Itens $\mathrm{I}_{46}\left(\mathrm{SHR}^{-}\right)$, $\mathrm{I}_{47}\left(\mathrm{CH} 2 \mathrm{a}^{-}\right), \mathrm{I}_{48}\left(\mathrm{CH}_{2} \mathrm{c}^{-}\right), \mathrm{I}_{49}\left(\mathrm{CH}^{-}\right)$e $\mathrm{I}_{50}\left(\mathrm{CH} 16^{-}\right)$. 


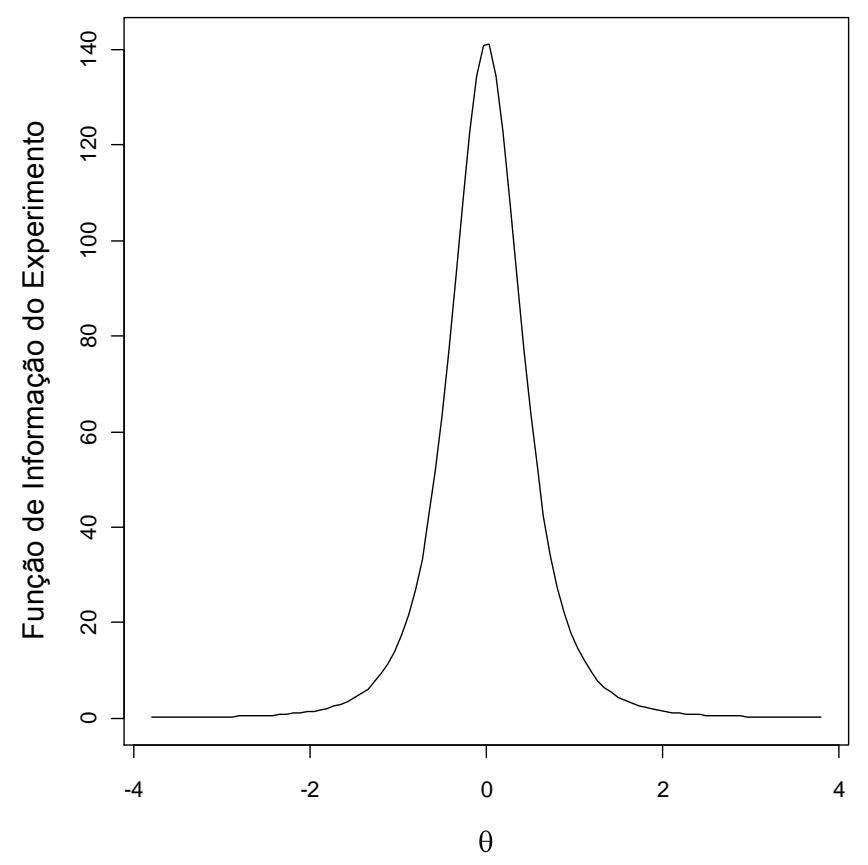

Total de Informação: 156.492

Informação no intervalo (-4, 0): 77.696 (49.65\%)

Informação no intervalo (0, 4): 78.547 (50.19\%)

Total de Informação: 156.492

Informação no intervalo (-2, 0): 76.902 (49.14\%)

Informação no intervalo (0, 2): 77.68 (49.64\%)

Figura 34. Função de Informação do Experimento.

De maneira geral, a partir da visualização das CCI e das interpretações dos valores presentes na Tabela 24, se percebe que, com exceção dos itens $I_{1}\left(S H R^{+}\right)$, $I_{2}\left(\mathrm{CH}_{2} \mathrm{a}^{+}\right), I_{3}\left(\mathrm{CH}_{2 c^{+}}\right)$e $I_{20}\left(\mathrm{CH}_{16} 6^{-}\right)$, os quais serão interpretados a seguir, os demais itens (condições experimentais) que compõem o experimento possuem parâmetros de dificuldade e discriminação muitos próximos, fato que pode ser visualmente notado pelos posicionamentos sobrepostos dos itens na escala latente construída (ver Figura 35 - apesar de não ser possível distinguir os itens nesta figura, o propósito da mesma é mostrar que de fato os itens estão de certa forma sobrepostos).

Por outro lado, na Figura 24 (à esquerda) é possível notar que os itens $I_{1}\left(S H R^{+}\right)$ e $I_{2}\left(\mathrm{CH}_{2} \mathrm{a}^{+}\right), \mathrm{I}_{3}\left(\mathrm{CH}_{2} \mathrm{c}^{+}\right)$possuem discriminações (inclinações) um tanto quanto distintas, apesar destes estarem posicionados próximos um dos outros na escala latente. Este comportamento "moderadamente" diferenciado entre as CCI é interessante, uma vez que para um dado valor predito da variável latente, digamos $\hat{\theta}=-1$, é possível observar diferenças entre as probabilidade de expressão, associadas aos fragmentos genéticos, para os itens $I_{1}\left(\mathrm{SHR}^{+}\right), I_{2}\left(\mathrm{CH}_{2} \mathrm{a}^{+}\right)$e $I_{3}\left(\mathrm{CH}_{2} \mathrm{c}^{+}\right)$, resultado que permite selecionar em cada item (condição experimental) os fragmentos genéticos com as 
maiores ou menores probabilidade de estarem expressos. Outra leitura da Figura 24 (à direita) retrata que este conjunto de itens, em especial os $I_{1}\left(\mathrm{SHR}^{+}\right)$e $I_{2}\left(\mathrm{CH}_{2} \mathrm{a}^{+}\right)$, contém pouca informação para os itens, ou seja, não contribuem para predizer a variável latente com precisão. Comportamento semelhante ocorre com o item $I_{20}\left(\mathrm{CH}_{16}{ }^{-}\right)$ apresentado na Figura 27.

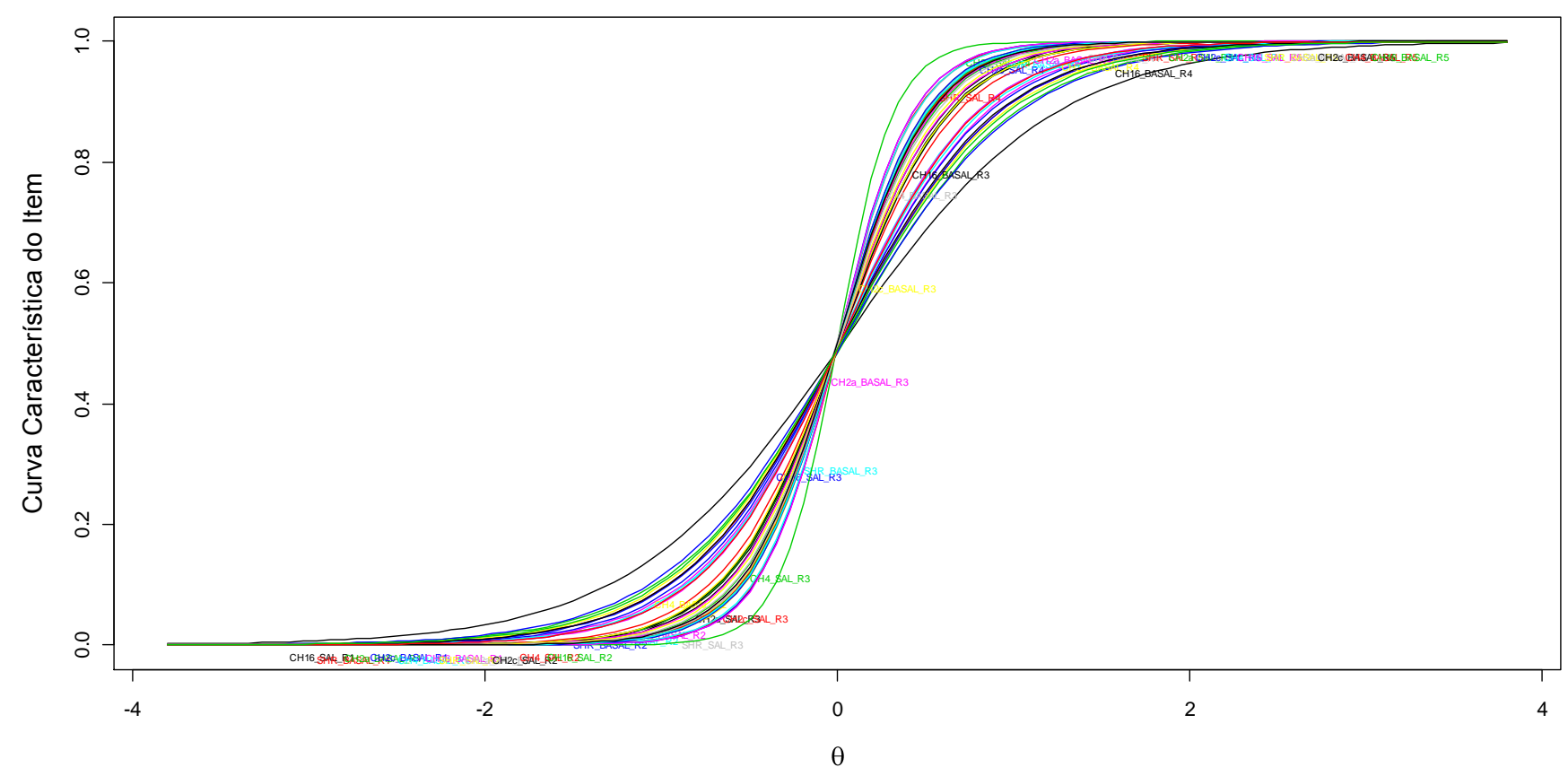

Figura 35. Curva Característica dos itens representados na Tabela 24, com exceção dos itens $\mathrm{I}_{46}\left(\mathrm{SHR}^{-}\right), \mathrm{I}_{47}\left(\mathrm{CH} 2 \mathrm{a}^{-}\right), \mathrm{I}_{48}\left(\mathrm{CH} 2 \mathrm{c}^{-}\right), \mathrm{I}_{49}\left(\mathrm{CH} 4^{-}\right)$e $\mathrm{I}_{50}\left(\mathrm{CH} 16^{-}\right)$.

Estes resultados, quando interpretados no contexto da TRI, levam à conclusão de que os 50 itens utilizados são altamente explicativos para se discriminar probabilidades de expressão gênica dentre os fragmentos genéticos avaliados, mas somente para um pequeno intervalo da escala, isto é, para valores latentes estimados próximos a zero da escala construída. Neste sentido, a escala construída está bem representada neste intervalo (ao redor de zero) e não no restante da mesma. Em termos biológicos, talvez, possa se interpretar que as alterações nas estruturas biológicas dos animais realizadas no experimento do InCor não sejam suficientes para capturar toda a variabilidade dos valores de expressão gênica associados à hipertensão. Outro resultado importante deve 
ser inferido a partir da leitura da FIT apresentada na Figura 35. Nota-se, a partir da leitura das informações na Figura 35, que a informação do experimento, relacionada à precisão com a qual a variável latente está sendo predita, está quase toda concentrada $(98,78 \%)$ em valores da variável latente no intervalo $(-2,2)$, intervalo onde se distribui os valores da variável latente preditos para os 11.564 fragmentos genéticos (ver Figura 36). Ainda, esta leitura informa que as predições com maior precisão são aquelas em que o valor latente predito está próximo de zero e, à medida que o valor de predição se afasta deste ponto, a precisão da predição diminui.
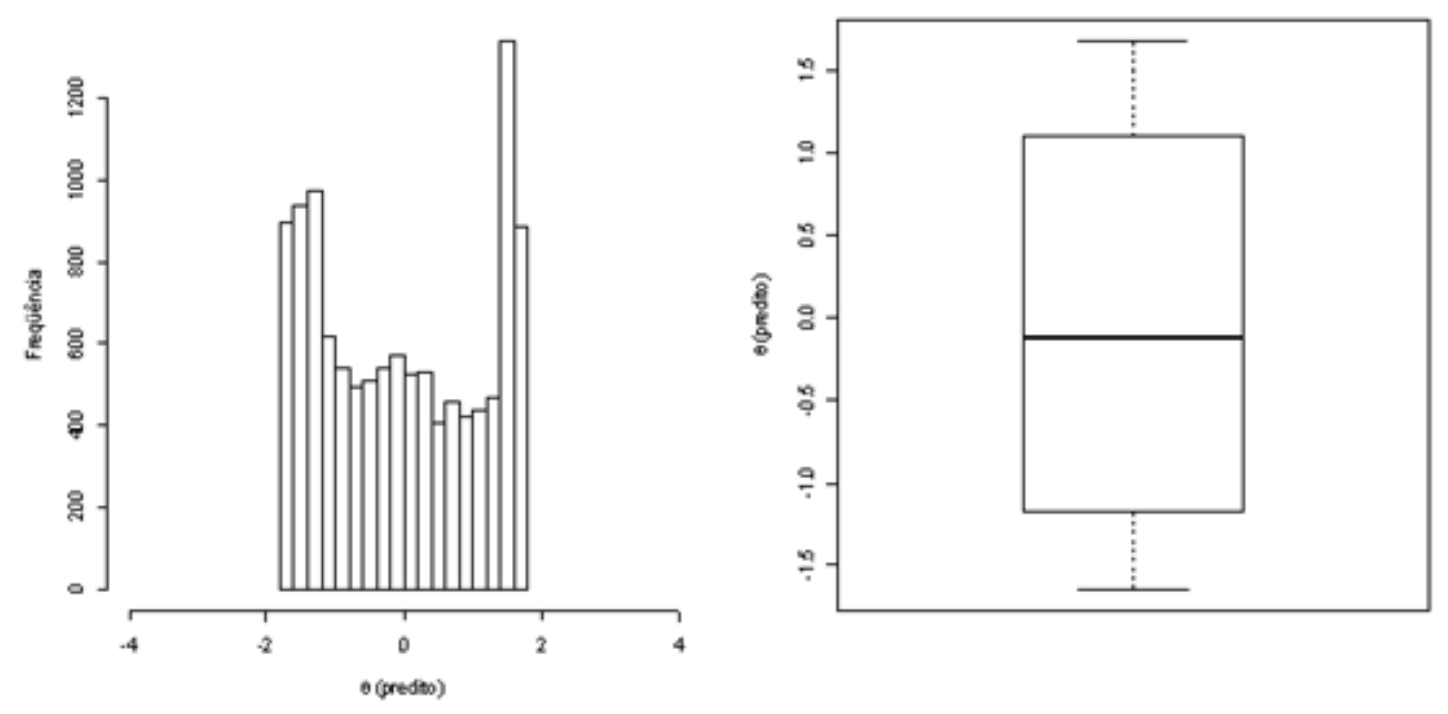

Figura 36. Distribuição dos valores da variável latente predita para os 11.564 fragmentos genéticos sob o modelo (4.2.2.2).

Por fim, talvez, a interpretação de maior valor prático sob os resultados seja aquela na qual a probabilidade de cada fragmento genético se expressar em cada item (condição experimental) é calculada. Como exemplo, está apresentado na Tabela 9 alguns valores para a variável latente predita e suas correspondentes médias (para 5 réplicas) das probabilidades de expressão gênica em cada condição experimental, segundo as estimativas do modelo (4.2.2.2). 
Tabela 9. Médias das probabilidades de expressão gênica em cada condição experimental (os desvios padrão estão indicados entre parênteses).

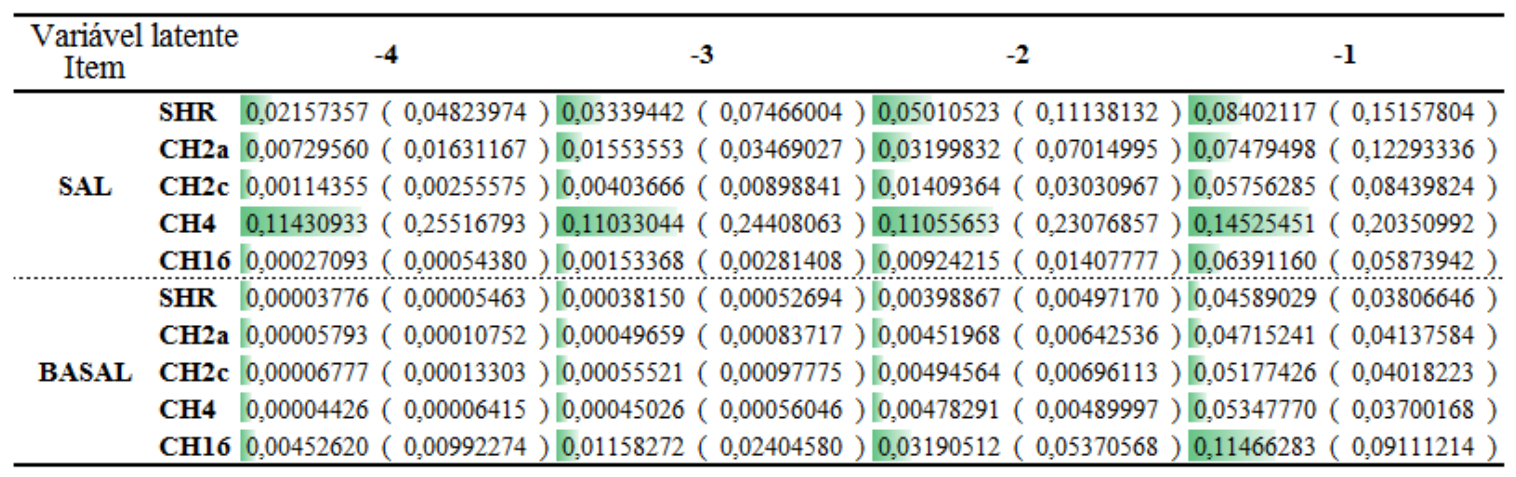

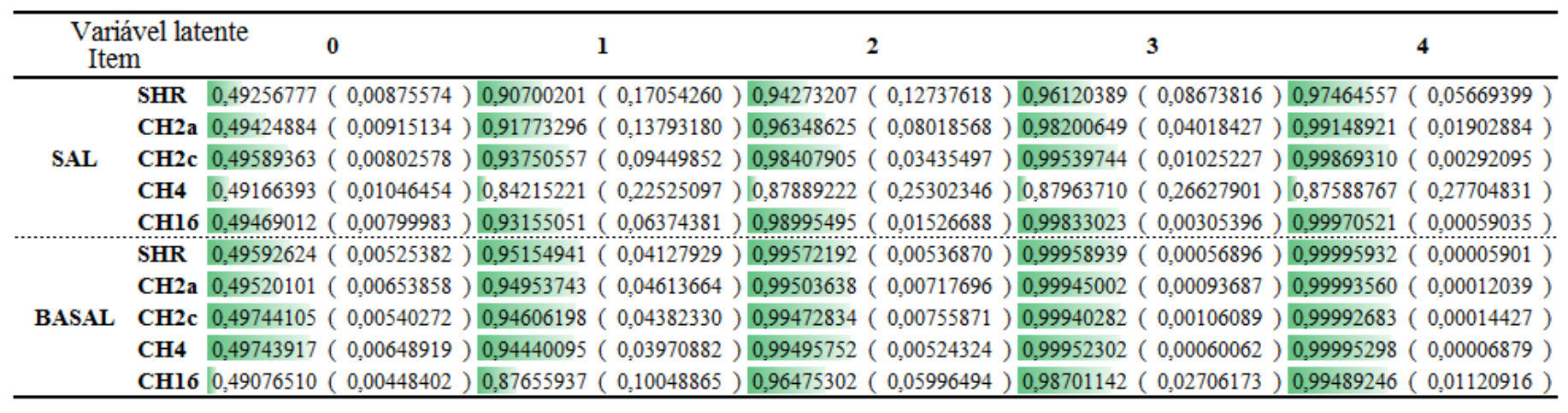

Extraindo as informações da Tabela 9, em princípio se nota que para baixos valores da variável latente preditos como, por exemplo, $-4,-3,-2$ e -1 , estes fragmentos genéticos têm maior probabilidade de se expressar na condição experimental CH4 após sal do que nas demais. Todavia, deve ser observado que os desvios padrão estimados para estes valores de variável latente são os maiores. Por outro lado, para fragmentos genéticos com valores da variável latente maiores do que -1 , fica difícil predizer em qual condição experimental estes terão maior probabilidade de se expressar, pois as probabilidade de expressão entre condições experimentais são muito próximas (o que já havia sido notado por meio da visualização da sobreposição das CCI).

Desta forma, frente aos resultados obtidos pela categorização dicotômica, e também na busca de se tentar absorver mais informação dos valores de expressão gênica se decidiu por analisar estes mesmos dados sob o seguinte critério de categorização politômico, 


$$
y_{i g}^{*}= \begin{cases}1 & \text { se mínimo }<y_{i g} \leq Q_{1_{i}} \\ 2 & \text { se } Q_{1_{i}}<y_{i g} \leq Q_{2_{i}} \\ 3 & \text { se } Q_{2_{i}}<y_{i g} \leq Q_{3_{i}} \\ 4 & \text { se } Q_{3_{i}}<y_{i g} \leq \text { máximo }\end{cases}
$$

com $y^{*}{ }_{i g}$ representando o valor categorizado do logaritmo do valor de expressão gênica normalizado pelo método da mediana do $g$ - ésimo fragmento genético no $i$ - ésimo item e, $Q_{1_{i}}, Q_{2_{i}}, Q_{3_{i}}$ representando, respectivamente, os valores dos percentis $25,50 \mathrm{e}$ 75 do $i$ - ésimo item.

De maneira análoga à categorização dicotômica, inicialmente, se verificou o número de fragmentos genéticos expressos com soma das categorias dos 50 itens igual a $S_{g}$ (ver Figura 37). Perceba que, para a categorização sob o critério politômico, não há fragmentos genéticos com valor de expressão gênica classificado na categoria mais baixa em todos os 50 itens. Por outro lado, ainda existem 2.895 fragmentos genéticos que possuem valor de expressão gênica classificado na categoria mais alta em todos os 50 itens. Desta forma, para a análise que se segue também foi feita a opção por excluir 2.895 fragmentos genéticos e daqueles com pelo menos uma perda de informação, sendo considerado 30.619 fragmentos genéticos no estágio de modelagem.

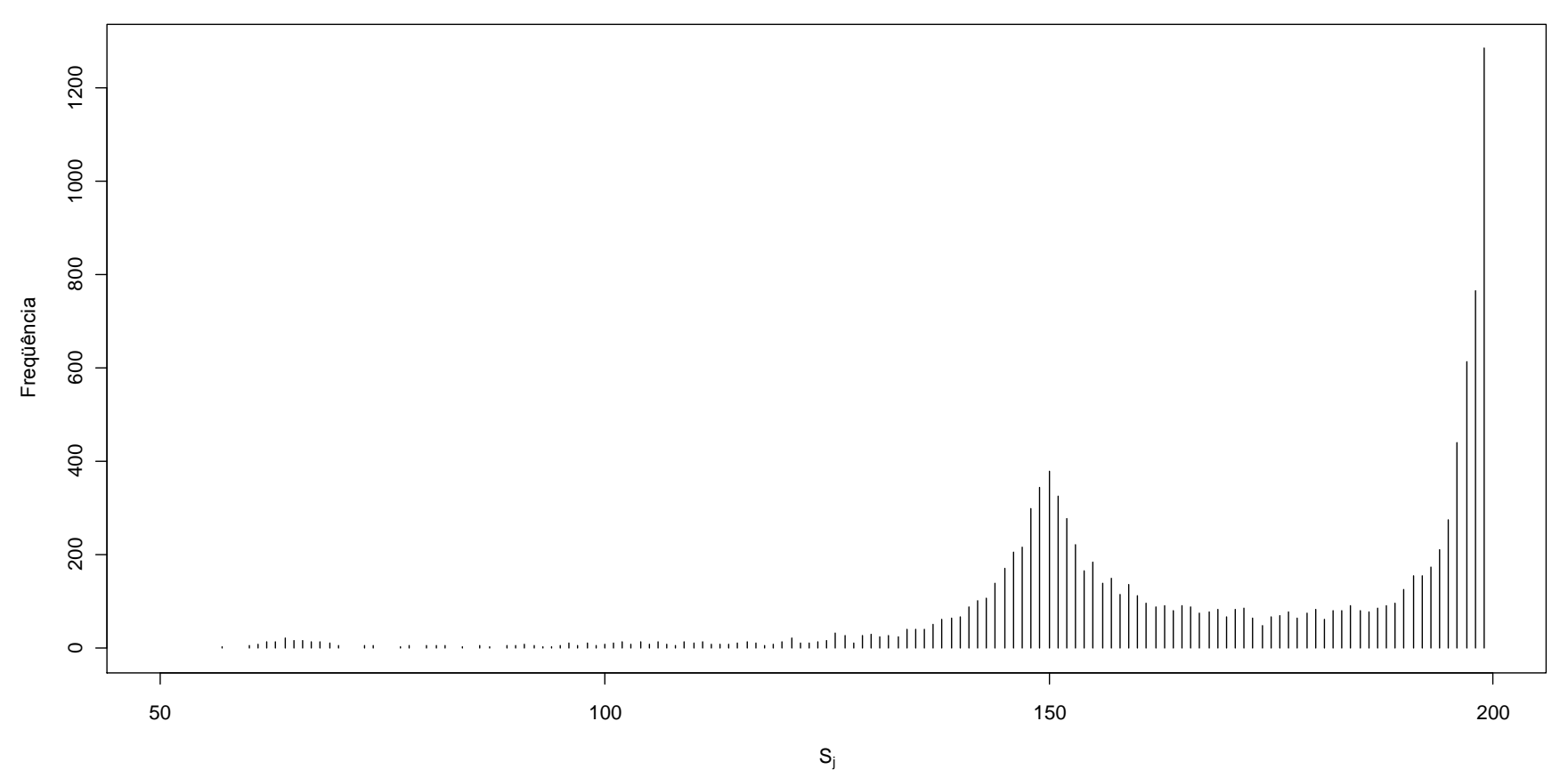

Figura 37. Distribuição de freqüência da estatística $S_{g}$. 
Após a exclusão dos fragmentos genéticos, o percentual de observações em cada uma das categorias dos itens pode ser observado na Tabela 10. Observe que a maioria dos fragmentos genéticos estão expressos nas categorias 3 (em média 44,2\%) e 4 (em média 47,7\%), com exceção dos itens $\mathrm{I}_{20}\left(\mathrm{CH} 16^{-}\right)$e $\mathrm{I}_{34}\left(\mathrm{CH} 4^{+}\right)$, onde a ocorrência de observações nas categorias 1 e 2 se destoam dos demais itens.

Tabela 10. Percentual de resposta para cada categorias dos itens.

\begin{tabular}{lcccc}
\hline & \multicolumn{4}{c}{ Percentual por categoria } \\
\cline { 2 - 5 } Item & $\mathbf{1}$ & $\mathbf{2}$ & $\mathbf{3}$ & $\mathbf{4}$ \\
\hline$I_{1}\left(S H R^{+}\right)$ & $7,52 \%$ & $11,88 \%$ & $33,17 \%$ & $47,42 \%$ \\
$I_{2}\left(C H 2 a^{+}\right)$ & $5,74 \%$ & $9,52 \%$ & $37,16 \%$ & $47,58 \%$ \\
$I_{3}\left(C H 2 c^{+}\right)$ & $5,55 \%$ & $9,05 \%$ & $37,71 \%$ & $47,68 \%$ \\
$I_{4}\left(C H 4^{+}\right)$ & $3,82 \%$ & $7,96 \%$ & $40,38 \%$ & $47,84 \%$ \\
$I_{5}\left(C H 16^{+}\right)$ & $4,40 \%$ & $7,95 \%$ & $39,73 \%$ & $47,92 \%$ \\
$I_{6}\left(S H R^{-}\right)$ & $2,26 \%$ & $6,44 \%$ & $43,55 \%$ & $47,75 \%$ \\
$I_{7}\left(C H 2 a^{-}\right)$ & $2,25 \%$ & $6,03 \%$ & $44,11 \%$ & $47,62 \%$ \\
$I_{8}\left(C H 2 c^{-}\right)$ & $2,89 \%$ & $6,55 \%$ & $42,76 \%$ & $47,79 \%$ \\
$I_{9}\left(C H 4^{-}\right)$ & $2,25 \%$ & $5,90 \%$ & $43,97 \%$ & $47,88 \%$ \\
$I_{10}\left(C H 16^{-}\right)$ & $2,17 \%$ & $5,72 \%$ & $44,47 \%$ & $47,63 \%$ \\
$I_{11}\left(S H R^{+}\right)$ & $1,50 \%$ & $3,93 \%$ & $46,94 \%$ & $47,63 \%$ \\
$I_{12}\left(C H 2 a^{+}\right)$ & $1,41 \%$ & $4,13 \%$ & $46,84 \%$ & $47,62 \%$ \\
$I_{13}\left(C H 2 c^{+}\right)$ & $1,42 \%$ & $4,63 \%$ & $46,29 \%$ & $47,67 \%$ \\
$I_{14}\left(C H 4^{+}\right)$ & $1,40 \%$ & $5,01 \%$ & $45,81 \%$ & $47,79 \%$ \\
$I_{15}\left(C H 16^{+}\right)$ & $1,78 \%$ & $4,64 \%$ & $45,92 \%$ & $47,67 \%$ \\
$I_{16}\left(S H R^{-}\right)$ & $2,33 \%$ & $5,93 \%$ & $43,98 \%$ & $47,76 \%$ \\
$I_{17}\left(C H 2 a^{-}\right)$ & $2,53 \%$ & $6,20 \%$ & $43,54 \%$ & $47,73 \%$ \\
$I_{18}\left(C H 2 c^{-}\right)$ & $3,14 \%$ & $6,27 \%$ & $42,81 \%$ & $47,79 \%$ \\
$I_{19}\left(C H 4^{-}\right)$ & $3,11 \%$ & $7,13 \%$ & $41,96 \%$ & $47,80 \%$ \\
\hline$I_{20}\left(C H 16^{-}\right)$ & $9,27 \%$ & $13,27 \%$ & $29,57 \%$ & $47,89 \%$ \\
\hline$I_{21}\left(S H R^{+}\right)$ & $1,54 \%$ & $3,77 \%$ & $47,04 \%$ & $47,65 \%$ \\
$I_{22}\left(C H 2 a^{+}\right)$ & $1,47 \%$ & $4,27 \%$ & $46,58 \%$ & $47,67 \%$ \\
$I_{23}\left(C H 2 c^{+}\right)$ & $1,37 \%$ & $4,12 \%$ & $46,84 \%$ & $47,66 \%$ \\
$I_{24}\left(C H 4^{+}\right)$ & $1,48 \%$ & $4,06 \%$ & $46,71 \%$ & $47,76 \%$ \\
$I_{25}\left(C H 16^{+}\right)$ & $1,39 \%$ & $5,06 \%$ & $45,94 \%$ & $47,60 \%$ \\
$I_{26}\left(S H R^{-}\right)$ & $1,50 \%$ & $4,08 \%$ & $46,74 \%$ & $47,68 \%$ \\
$I_{27}\left(C H 2 a^{-}\right)$ & $1,46 \%$ & $4,24 \%$ & $46,61 \%$ & $47,69 \%$ \\
$I_{28}\left(C H 2 c^{-}\right)$ & $1,50 \%$ & $4,06 \%$ & $46,77 \%$ & $47,67 \%$ \\
$I_{29}\left(C H 4^{-}\right)$ & $1,44 \%$ & $3,91 \%$ & $47,04 \%$ & $47,61 \%$ \\
$I_{30}\left(C H 16^{-}\right)$ & $1,56 \%$ & $4,54 \%$ & $46,21 \%$ & $47,69 \%$ \\
\end{tabular}




\begin{tabular}{|lcccc|}
\hline$I_{31}\left(\mathrm{SHR}^{+}\right)$ & $1,43 \%$ & $3,62 \%$ & $47,35 \%$ & $47,60 \%$ \\
$I_{32}\left(\mathrm{CH} 2 \mathrm{a}^{+}\right)$ & $1,42 \%$ & $3,63 \%$ & $47,29 \%$ & $47,66 \%$ \\
$I_{33}\left(\mathrm{CH} 2 \mathrm{c}^{+}\right)$ & $1,48 \%$ & $4,00 \%$ & $46,80 \%$ & $47,73 \%$ \\
\hline$I_{34}\left(\mathrm{CH} 4^{+}\right)$ & $12,47 \%$ & $15,67 \%$ & $24,28 \%$ & $47,58 \%$ \\
\hline$I_{35}\left(\mathrm{CH} 16^{+}\right)$ & $1,55 \%$ & $3,62 \%$ & $47,09 \%$ & $47,74 \%$ \\
$I_{36}\left(\mathrm{SHR} \mathrm{R}^{-}\right)$ & $1,37 \%$ & $3,96 \%$ & $46,97 \%$ & $47,70 \%$ \\
$I_{37}\left(\mathrm{CH} 2 a^{-}\right)$ & $1,44 \%$ & $3,87 \%$ & $46,99 \%$ & $47,69 \%$ \\
$I_{38}\left(\mathrm{CH} 2 \mathrm{c}^{-}\right)$ & $1,57 \%$ & $4,17 \%$ & $46,43 \%$ & $47,84 \%$ \\
$I_{39}\left(\mathrm{CH} 4^{-}\right)$ & $1,51 \%$ & $3,96 \%$ & $46,64 \%$ & $47,89 \%$ \\
$I_{40}\left(\mathrm{CH} 16^{-}\right)$ & $1,84 \%$ & $5,52 \%$ & $44,79 \%$ & $47,86 \%$ \\
$I_{41}\left(\mathrm{SHR} \mathrm{R}^{+}\right)$ & $1,58 \%$ & $4,69 \%$ & $46,15 \%$ & $47,58 \%$ \\
$I_{42}\left(\mathrm{CH} 2 \mathrm{a}^{+}\right)$ & $1,58 \%$ & $4,93 \%$ & $45,87 \%$ & $47,62 \%$ \\
$I_{43}\left(\mathrm{CH} 2 \mathrm{c}^{+}\right)$ & $1,55 \%$ & $4,71 \%$ & $46,06 \%$ & $47,68 \%$ \\
$I_{44}\left(\mathrm{CH} 4^{+}\right)$ & $1,57 \%$ & $4,91 \%$ & $45,88 \%$ & $47,63 \%$ \\
$I_{45}\left(\mathrm{CH} 16^{+}\right)$ & $1,76 \%$ & $4,76 \%$ & $45,80 \%$ & $47,67 \%$ \\
$I_{46}\left(\mathrm{SHR} \mathrm{R}^{-}\right)$ & $1,95 \%$ & $5,08 \%$ & $45,30 \%$ & $47,67 \%$ \\
$I_{47}\left(\mathrm{CH} 2 a^{-}\right)$ & $1,63 \%$ & $5,36 \%$ & $45,31 \%$ & $47,69 \%$ \\
$I_{48}\left(\mathrm{CH} 2 c^{-}\right)$ & $1,76 \%$ & $4,65 \%$ & $45,79 \%$ & $47,79 \%$ \\
$I_{49}\left(\mathrm{CH} 4^{-}\right)$ & $1,05 \%$ & $4,79 \%$ & $46,39 \%$ & $47,76 \%$ \\
$I_{50}\left(\mathrm{CH} 16^{-}\right)$ & $2,46 \%$ & $6,18 \%$ & $43,52 \%$ & $47,84 \%$ \\
\hline
\end{tabular}

Prosseguindo com a análise, de modo a estimar os parâmetros dos 50 itens e as variáveis latentes dos 30.619 fragmentos genéticos se fez o ajuste do modelo Samejima apresentado em (4.3.2.2), se obtendo as estimativas apresentadas na Tabela 11.

Tabela 11. Estimativas dos parâmetros do Modelo Samejima em (4.3.2.2).

\begin{tabular}{lcccccccc}
\hline & \multicolumn{3}{c}{ Erro padrão } & \multicolumn{3}{c}{ Erro padrão } & \multicolumn{3}{c}{ Erro padrão } & \multicolumn{2}{c}{ Erro padrão } \\
\multicolumn{1}{c}{ Item $i$} & $b_{i, 2}$ & $\left(b_{i, 2}\right)$ & $b_{i, 3}$ & $\left(b_{i, 3}\right)$ & $b_{i, 4}$ & $\left(b_{i, 4}\right)$ & $a_{i}$ & $\left(a_{i}\right)$ \\
\hline$I_{1}\left(S H R^{+}\right)$ & $-1,722$ & 0,022 & 0,176 & 0,018 & 3,328 & 0,142 & 0,683 & 0,006 \\
$I_{2}\left(C H 2 a^{+}\right)$ & $-1,655$ & 0,017 & 0,450 & 0,014 & 3,106 & 0,216 & 0,975 & 0,008 \\
$I_{3}\left(C H 2 c^{+}\right)$ & $-1,690$ & 0,015 & $-0,004$ & 0,014 & 2,720 & 0,205 & 1,113 & 0,009 \\
$I_{4}\left(C H 4^{+}\right)$ & $-1,740$ & 0,016 & 0,278 & 0,012 & 3,146 & 0,252 & 1,053 & 0,008 \\
$I_{5}\left(C H 16^{+}\right)$ & $-1,853$ & 0,013 & 0,031 & 0,012 & 3,000 & 0,388 & 1,328 & 0,010 \\
$I_{6}\left(S H R^{-}\right)$ & $-1,620$ & 0,009 & 0,084 & 0,011 & 2,976 & 2,034 & 2,051 & 0,016 \\
$I_{7}\left(C H 2 a^{-}\right)$ & $-1,533$ & 0,010 & 0,159 & 0,011 & 2,622 & 1,235 & 2,033 & 0,019 \\
$I_{8}\left(C H 2 c^{-}\right)$ & $-1,533$ & 0,011 & 0,150 & 0,010 & 2,901 & 0,824 & 1,710 & 0,013 \\
$I_{9}\left(C H 4^{-}\right)$ & $-1,568$ & 0,009 & 0,417 & 0,009 & 2,837 & 1,862 & 2,093 & 0,015 \\
$I_{10}\left(C H 16^{-}\right)$ & $-1,581$ & 0,009 & 0,192 & 0,011 & 2,731 & 1,552 & 2,075 & 0,018 \\
$I_{11}\left(S H R^{+}\right)$ & $-1,370$ & 0,008 & 0,493 & 0,008 & 2,661 & 4,786 & 2,618 & 0,021
\end{tabular}




\begin{tabular}{|c|c|c|c|c|c|c|c|c|}
\hline$I_{12}\left(C H 2 a^{+}\right)$ & $-1,592$ & 0,009 & 0,126 & 0,011 & 2,880 & 4,868 & 2,463 & 0,020 \\
\hline$I_{13}\left(C H 2 c^{+}\right)$ & $-1,717$ & 0,009 & 0,089 & 0,011 & 2,982 & 3,729 & 2,287 & 0,018 \\
\hline$I_{14}\left(\mathrm{CH}_{4}^{+}\right)$ & $-1,606$ & 0,009 & 0,157 & 0,010 & 2,886 & 2,868 & 2,246 & 0,018 \\
\hline$I_{15}\left(C H 16^{+}\right)$ & $-1,565$ & 0,009 & 0,285 & 0,010 & 2,710 & 2,333 & 2,267 & 0,019 \\
\hline$I_{16}\left(S H R^{-}\right)$ & $-1,599$ & 0,011 & 0,082 & 0,011 & 2,939 & 0,844 & 1,703 & 0,013 \\
\hline$I_{17}\left(C H 2 a^{-}\right)$ & $-1,533$ & 0,011 & 0,105 & 0,011 & 2,922 & 0,657 & 1,601 & 0,012 \\
\hline$I_{18}\left(C H 2 c^{-}\right)$ & $-1,495$ & 0,011 & 0,241 & 0,010 & 2,824 & 0,654 & 1,640 & 0,012 \\
\hline$I_{19}\left(\mathrm{CH}_{4}^{-}\right)$ & $-1,540$ & 0,012 & 0,234 & 0,011 & 2,831 & 0,373 & 1,372 & 0,011 \\
\hline$I_{20}\left(C H 16^{-}\right)$ & $-1,821$ & 0,022 & 0,435 & 0,017 & 3,353 & 0,164 & 0,758 & 0,007 \\
\hline$I_{21}\left(S_{H R} R^{+}\right)$ & $-1,422$ & 0,008 & 0,337 & 0,008 & 2,818 & 22,762 & 3,137 & 0,025 \\
\hline$I_{22}\left(C H 2 a^{+}\right)$ & $-1,522$ & 0,008 & 0,291 & 0,009 & 2,768 & 8,774 & 2,789 & 0,024 \\
\hline$I_{23}\left(C H 2 c^{+}\right)$ & $-1,383$ & 0,008 & 0,260 & 0,009 & 2,676 & 6,159 & 2,711 & 0,024 \\
\hline$I_{24}\left(\mathrm{CH}_{4}^{+}\right)$ & $-1,513$ & 0,008 & 0,214 & 0,012 & 2,625 & 10,815 & 2,973 & 0,031 \\
\hline$I_{25}\left(C H 16^{+}\right)$ & $-1,514$ & 0,009 & 0,422 & 0,008 & 2,648 & 3,444 & 2,478 & 0,021 \\
\hline$I_{26}\left(S H R^{-}\right)$ & $-1,507$ & 0,008 & 0,215 & 0,009 & 2,996 & 12,679 & 2,760 & 0,020 \\
\hline$I_{27}\left(\mathrm{CH}_{2} a^{-}\right)$ & $-1,471$ & 0,008 & 0,141 & 0,010 & 2,875 & 8,370 & 2,689 & 0,022 \\
\hline$I_{28}\left(C H 2 c^{-}\right)$ & $-1,462$ & 0,008 & 0,328 & 0,008 & 2,806 & 8,783 & 2,764 & 0,022 \\
\hline$I_{29}\left(\mathrm{CH}_{4}^{-}\right)$ & $-1,533$ & 0,008 & 0,157 & 0,012 & 2,726 & 16,809 & 3,071 & 0,031 \\
\hline$I_{30}\left(\mathrm{CH}_{16} 6^{-}\right)$ & $-1,447$ & 0,008 & 0,262 & 0,009 & 2,693 & 7,707 & 2,790 & 0,025 \\
\hline$I_{31}\left(S_{H R}^{+}\right)$ & $-1,510$ & 0,008 & 0,307 & 0,008 & 2,830 & 18,481 & 3,042 & 0,024 \\
\hline$I_{32}\left(C H 2 a^{+}\right)$ & $-1,609$ & 0,008 & 0,165 & 0,010 & 3,063 & 31,404 & 3,046 & 0,022 \\
\hline$I_{33}\left(C H 2 c^{+}\right)$ & $-1,441$ & 0,008 & 0,312 & 0,008 & 2,778 & 8,055 & 2,752 & 0,022 \\
\hline$I_{34}\left(\mathrm{CH}_{4}^{+}\right)$ & $-3,080$ & 0,048 & 0,744 & 0,029 & 4,625 & 0,165 & 0,411 & 0,005 \\
\hline$I_{35}\left(C H 16^{+}\right)$ & $-1,520$ & 0,008 & 0,259 & 0,010 & 2,747 & 9,886 & 2,856 & 0,025 \\
\hline$I_{36}\left(S H R^{-}\right)$ & $-1,504$ & 0,008 & 0,227 & 0,009 & 2,901 & 13,606 & 2,862 & 0,022 \\
\hline$I_{37}\left(C H 2 a^{-}\right)$ & $-1,437$ & 0,008 & 0,181 & 0,009 & 3,051 & 14,051 & 2,759 & 0,020 \\
\hline$I_{38}\left(C H 2 c^{-}\right)$ & $-1,604$ & 0,008 & 0,140 & 0,011 & 2,943 & 12,620 & 2,797 & 0,022 \\
\hline$I_{39}\left(\mathrm{CH}_{4}^{-}\right)$ & $-1,457$ & 0,008 & 0,321 & 0,008 & 2,740 & 5,997 & 2,660 & 0,022 \\
\hline$I_{40}\left(C H 16^{-}\right)$ & $-1,598$ & 0,009 & 0,315 & 0,009 & 2,895 & 2,869 & 2,239 & 0,017 \\
\hline$I_{41}\left(S H R^{+}\right)$ & $-1,466$ & 0,009 & 0,288 & 0,009 & 2,822 & 4,305 & 2,456 & 0,019 \\
\hline$I_{42}\left(\mathrm{CH}_{2} \mathrm{a}^{+}\right)$ & $-1,472$ & 0,008 & 0,349 & 0,008 & 2,790 & 6,737 & 2,665 & 0,021 \\
\hline$I_{43}\left(\mathrm{CH}_{2} \mathrm{c}^{+}\right)$ & $-1,514$ & 0,008 & 0,180 & 0,010 & 2,859 & 5,697 & 2,544 & 0,021 \\
\hline $\mathrm{I}_{44}\left(\mathrm{CH}_{4}^{+}\right)$ & $-1,508$ & 0,009 & 0,141 & 0,010 & 2,840 & 4,298 & 2,442 & 0,020 \\
\hline$I_{45}\left(C H 16^{+}\right)$ & $-1,626$ & 0,009 & 0,331 & 0,009 & 2,908 & 2,449 & 2,166 & 0,016 \\
\hline$I_{46}\left(S H R^{-}\right)$ & $-1,505$ & 0,009 & 0,274 & 0,009 & 2,912 & 3,672 & 2,330 & 0,017 \\
\hline$I_{47}\left(\mathrm{CH}_{2} \mathrm{a}^{-}\right)$ & $-1,449$ & 0,009 & 0,332 & 0,008 & 2,813 & 3,014 & 2,315 & 0,018 \\
\hline$I_{48}\left(C H 2 c^{-}\right)$ & $-1,498$ & 0,008 & 0,279 & 0,008 & 2,962 & 5,344 & 2,450 & 0,018 \\
\hline$I_{49}\left(\mathrm{CH}_{4}^{-}\right)$ & $-1,539$ & 0,009 & 0,202 & 0,010 & 2,808 & 2,131 & 2,171 & 0,018 \\
\hline$I_{50}\left(C H 16^{-}\right)$ & $-1,492$ & 0,010 & 0,179 & 0,010 & 2,843 & 0,957 & 1,805 & 0,014 \\
\hline
\end{tabular}

A interpretação dos resultados para o modelo Samejima ajustado também pode ser realizada com as mesmas ferramentas utilizadas anteriormente para o ML2. Para exemplificar, serão apresentadas a seguir as curvas características dos itens $\mathrm{I}_{1}\left(\mathrm{SHR}^{+}\right)$, 
$\mathrm{I}_{11}\left(\mathrm{SHR}^{+}\right), \mathrm{I}_{21}\left(\mathrm{SHR}^{+}\right), \mathrm{I}_{31}\left(\mathrm{SHR}^{+}\right), \mathrm{I}_{41}\left(\mathrm{SHR}^{+}\right), \mathrm{I}_{6}\left(\mathrm{SHR}^{-}\right), \mathrm{I}_{16}\left(\mathrm{SHR}^{-}\right), \mathrm{I}_{26}\left(\mathrm{SHR}^{-}\right)$ $\mathrm{I}_{36}\left(\mathrm{SHR}^{-}\right)$e $\mathrm{I}_{46}\left(\mathrm{SHR}^{-}\right)$para todas as categorias de resposta e suas respectivas Funções de Informação do Item (para os demais itens ver Apêndice B).

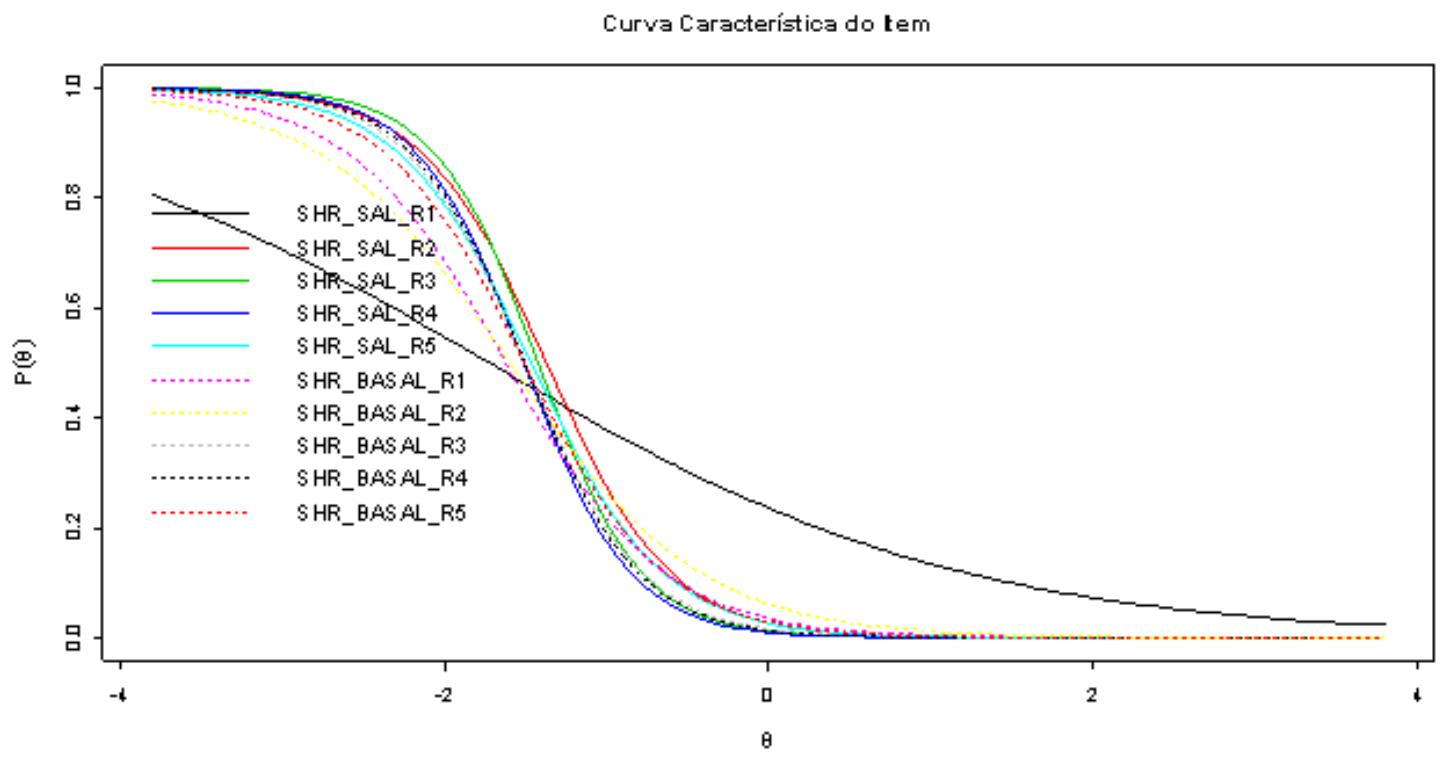

Figura 38. Curvas de probabilidades para a categoria 1 dos $\mathrm{I}_{1}\left(\mathrm{SHR}^{+}\right), \mathrm{I}_{11}\left(\mathrm{SHR}^{+}\right)$, $\mathrm{I}_{21}\left(\mathrm{SHR}^{+}\right), \mathrm{I}_{31}\left(\mathrm{SHR}^{+}\right), \mathrm{I}_{41}\left(\mathrm{SHR}^{+}\right), \mathrm{I}_{6}\left(\mathrm{SHR}^{-}\right), \mathrm{I}_{16}\left(\mathrm{SHR}^{-}\right), \mathrm{I}_{26}\left(\mathrm{SHR}^{-}\right) \mathrm{I}_{36}\left(\mathrm{SHR}^{-}\right)$e $\mathrm{I}_{46}\left(\mathrm{SHR}^{-}\right)$para a categoria de resposta $y^{*}{ }_{i g}=1$.

Curva Característica do tem

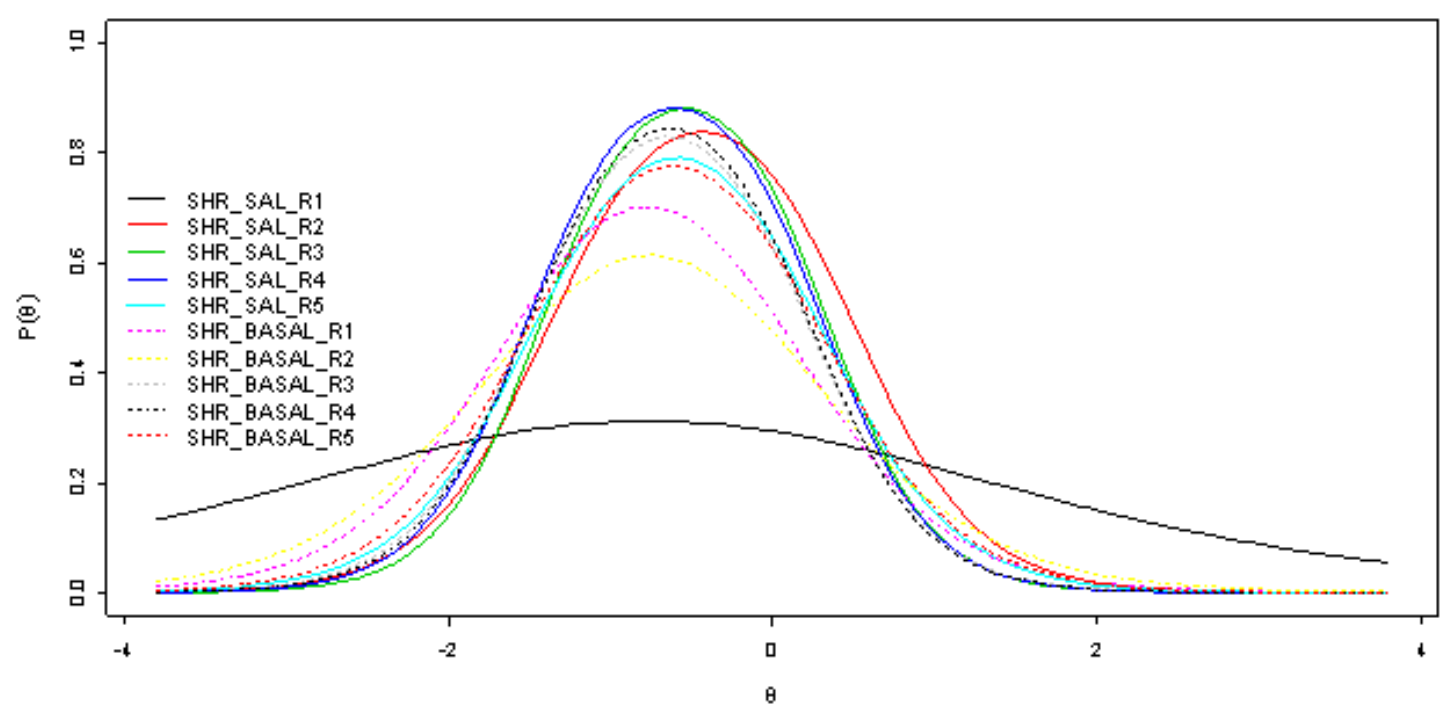


Figura 39. Curvas de probabilidades para a categoria 2 dos $I_{1}\left(\mathrm{SHR}^{+}\right), \mathrm{I}_{11}\left(\mathrm{SHR}^{+}\right)$, $\mathrm{I}_{21}\left(\mathrm{SHR}^{+}\right), \mathrm{I}_{31}\left(\mathrm{SHR}^{+}\right), \mathrm{I}_{41}\left(\mathrm{SHR}^{+}\right), \mathrm{I}_{6}\left(\mathrm{SHR}^{-}\right), \mathrm{I}_{16}\left(\mathrm{SHR}^{-}\right), \mathrm{I}_{26}\left(\mathrm{SHR}^{-}\right) \mathrm{I}_{36}\left(\mathrm{SHR}^{-}\right) \mathrm{e}$ $\mathrm{I}_{46}\left(\mathrm{SHR}^{-}\right)$para a categoria de resposta $y^{*}{ }_{i g}=2$.

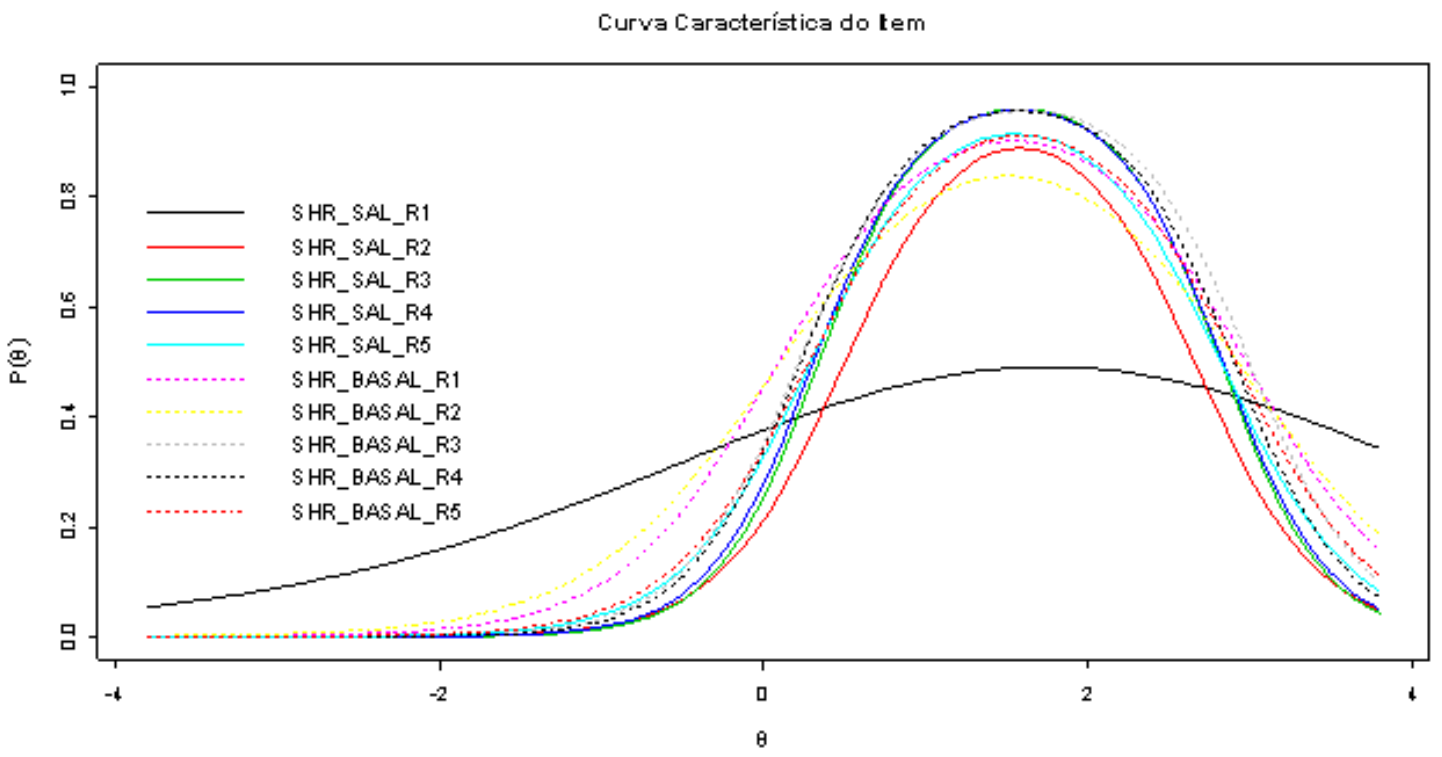

Figura 40. Curvas de probabilidades para a categoria 3 dos $I_{1}\left(\mathrm{SHR}^{+}\right), \mathrm{I}_{11}\left(\mathrm{SHR}^{+}\right)$, $\mathrm{I}_{21}\left(\mathrm{SHR}^{+}\right), \mathrm{I}_{31}\left(\mathrm{SHR}^{+}\right), \mathrm{I}_{41}\left(\mathrm{SHR}^{+}\right), \mathrm{I}_{6}\left(\mathrm{SHR}^{-}\right), \mathrm{I}_{16}\left(\mathrm{SHR}^{-}\right), \mathrm{I}_{26}\left(\mathrm{SHR}^{-}\right) \mathrm{I}_{36}\left(\mathrm{SHR}^{-}\right) \mathrm{e}$ $\mathrm{I}_{46}\left(\mathrm{SHR}^{-}\right)$para a categoria de resposta $y^{*}{ }_{i g}=3$. 
Curva Característica do tem

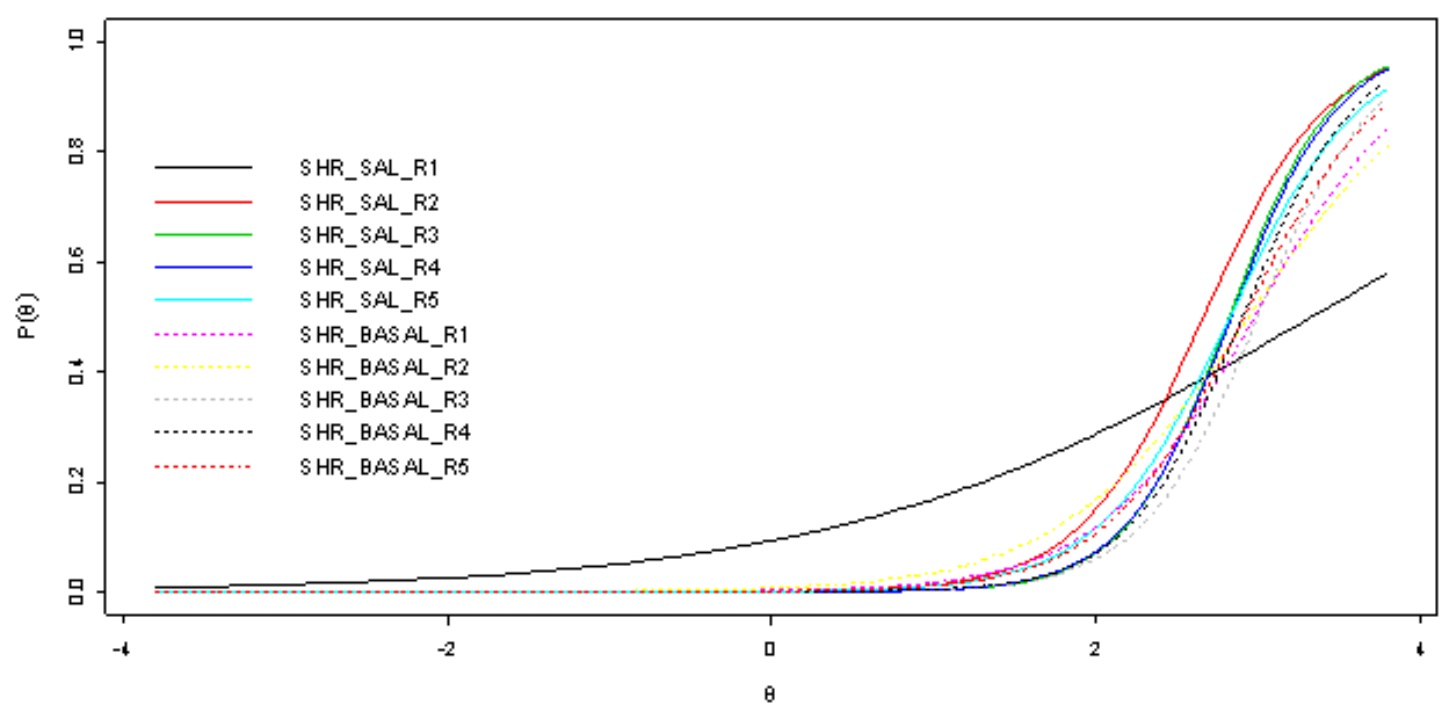

Figura 41. Curvas de probabilidades para a categoria $4 \operatorname{dos} \mathrm{I}_{1}\left(\mathrm{SHR}^{+}\right), \mathrm{I}_{11}\left(\mathrm{SHR}^{+}\right)$, $\mathrm{I}_{21}\left(\mathrm{SHR}^{+}\right), \mathrm{I}_{31}\left(\mathrm{SHR}^{+}\right), \mathrm{I}_{41}\left(\mathrm{SHR}^{+}\right), \mathrm{I}_{6}\left(\mathrm{SHR}^{-}\right), \mathrm{I}_{16}\left(\mathrm{SHR}^{-}\right), \mathrm{I}_{26}\left(\mathrm{SHR}^{-}\right) \mathrm{I}_{36}\left(\mathrm{SHR}^{-}\right) \mathrm{e}$ $\mathrm{I}_{46}\left(\mathrm{SHR}^{-}\right)$para a categoria de resposta $y^{*}{ }_{i g}=4$.

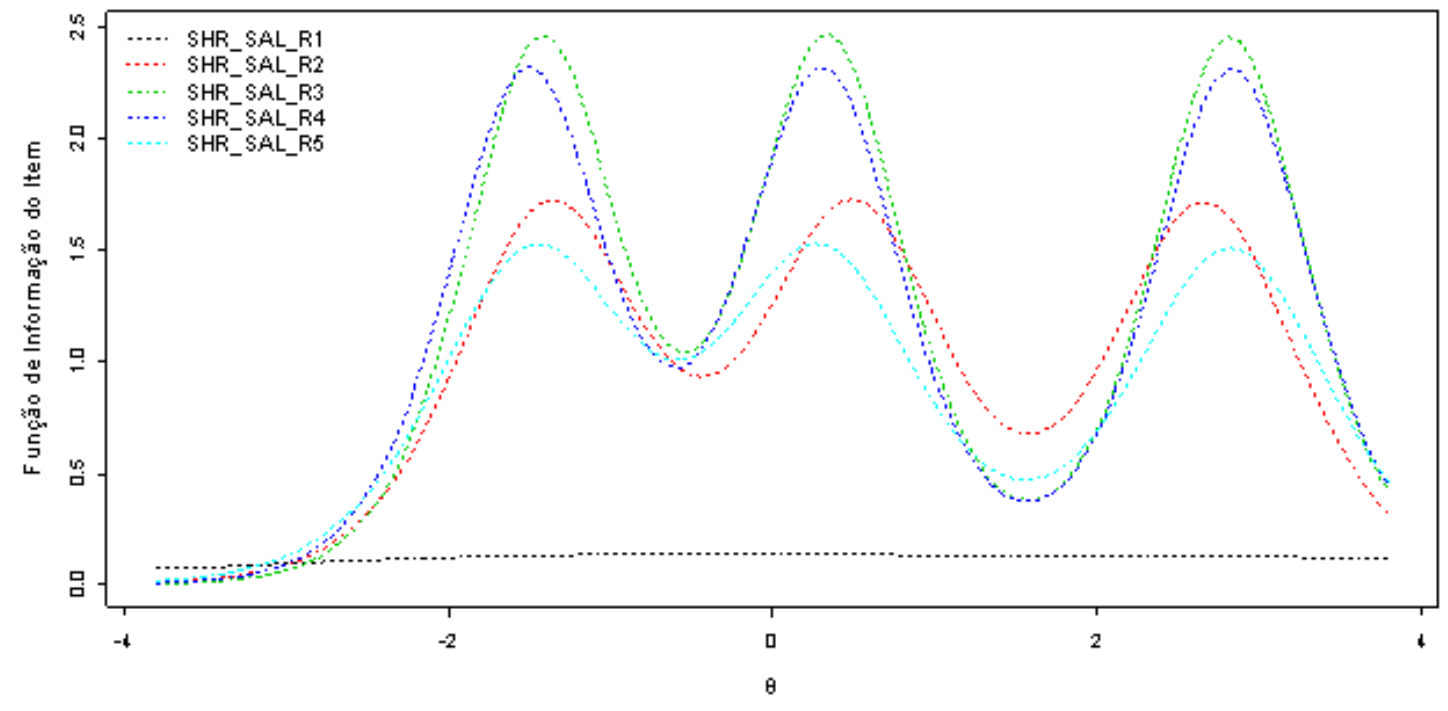

Figura 42. Função de Informação dos itens $I_{1}\left(\mathrm{SHR}^{+}\right), I_{11}\left(\mathrm{SHR}^{+}\right), I_{21}\left(\mathrm{SHR}^{+}\right)$, $\mathrm{I}_{31}\left(\mathrm{SHR}^{+}\right)$e $\mathrm{I}_{41}\left(\mathrm{SHR}^{+}\right)$ 


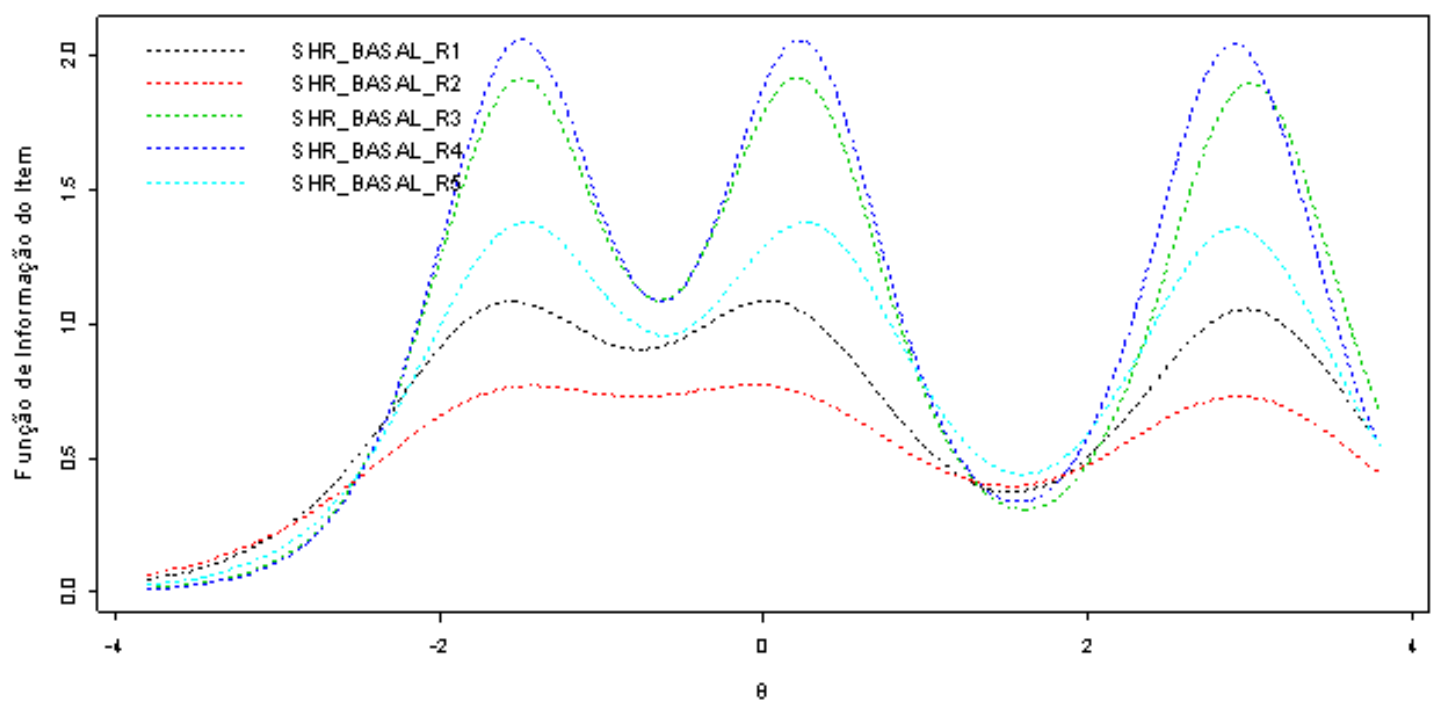

Figura 43. Função de Informação dos itens $\mathrm{I}_{6}\left(\mathrm{SHR}^{-}\right), \mathrm{I}_{16}\left(\mathrm{SHR}^{-}\right), \mathrm{I}_{26}\left(\mathrm{SHR}^{-}\right)$ $\mathrm{I}_{36}\left(\mathrm{SHR}^{-}\right)$e $\mathrm{I}_{46}\left(\mathrm{SHR}^{-}\right)$.

A partir da leitura da Tabela 11 e das CCI nas Figuras 38, 39, 40 e 41, se percebe que, ao adotar o critério de categorização politômico, ocorre maiores discriminações entre itens e, inclusive, sutis mudanças no que diz respeito ao posicionamento dos itens na escala latente. Estes resultados permitem que, por exemplo, fragmentos genéticos com pequenas diferenças em seus valores preditos para a variável latente possam ter probabilidades bastante distintas de estarem expressos, por exemplo, em uma mesma condição experimental. Para exemplificar, suponha que um particular fragmento genético tenha valor 2 predito para sua variável latente. Observando as CCI apresentadas na Figura 44, as quais descrevem as probabilidades dos fragmentos genéticos estarem expressos nos itens $I_{1}\left(\mathrm{SHR}^{+}\right), I_{2}\left(\mathrm{CH}_{2} \mathrm{a}^{+}\right)$e $I_{3}\left(\mathrm{CH}_{2} \mathrm{c}^{+}\right)$, se pode observar que o fragmento genético com variável latente predita igual a 2 têm maior probabilidade de estar expresso na linhagem $\mathrm{CH}_{2} \mathrm{c}^{+}$(comparando apenas as linhagens citadas no bloco 1), na categoria $y^{*}{ }_{i g}=3$. 

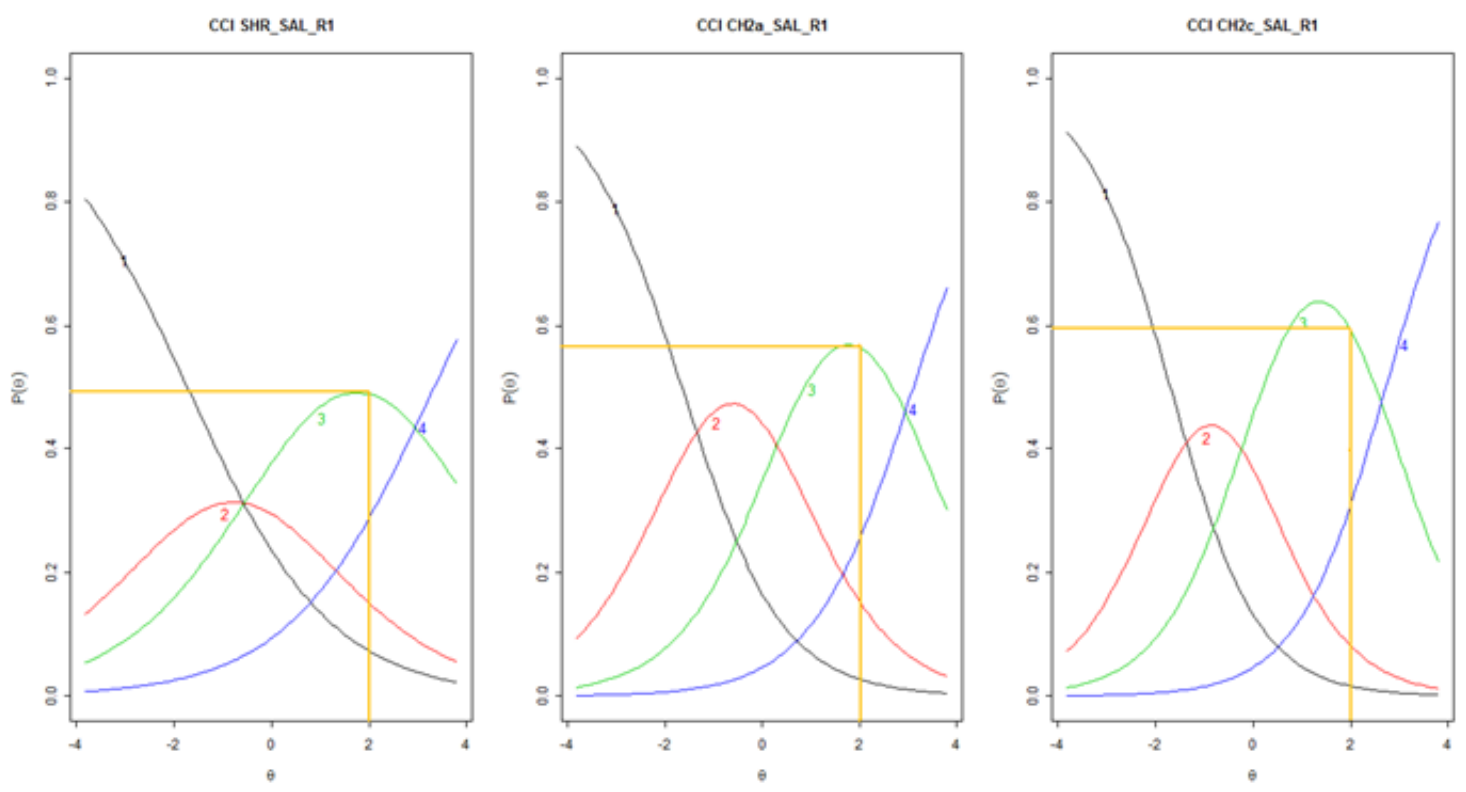

Figura 44. Curva Característica dos itens $\mathrm{I}_{1}\left(\mathrm{SHR}^{+}\right), \mathrm{I}_{2}\left(\mathrm{CH} 2 \mathrm{a}^{+}\right)$e $\mathrm{I}_{3}\left(\mathrm{CH} 2 \mathrm{c}^{+}\right)$.

Outra leitura interessante utilizando ainda a Figura 44 e, em particular a CCI do $\mathrm{I}_{1}\left(\mathrm{SHR}^{+}\right)$, é observar que para a condição experimental $\mathrm{SHR}^{+}$é pouco provável que fragmentos genéticos tenham valor de expressão gênica na categoria 2, pois a probabilidade de ocorrência desta categoria é quase sempre inferior às demais categorias para toda a escala latente.

Além dos pontos citados anteriormente, observando a Figura 42 e 43 se nota que, em decorrência de se considerar mais duas categorias para os valores de expressão gênica, o valor latente dos fragmentos genéticos passa a ser estimado com maior precisão ao longo da escala latente, diferente da categorização dicotômica onde os parâmetros eram estimados com precisão no intervalo $(-2 ; 2)$. A distribuição da variável latente para os 30.619 fragmentos genéticos estimadas pelo modelo (4.3.2.2) pode ser observada na Figura 45. 

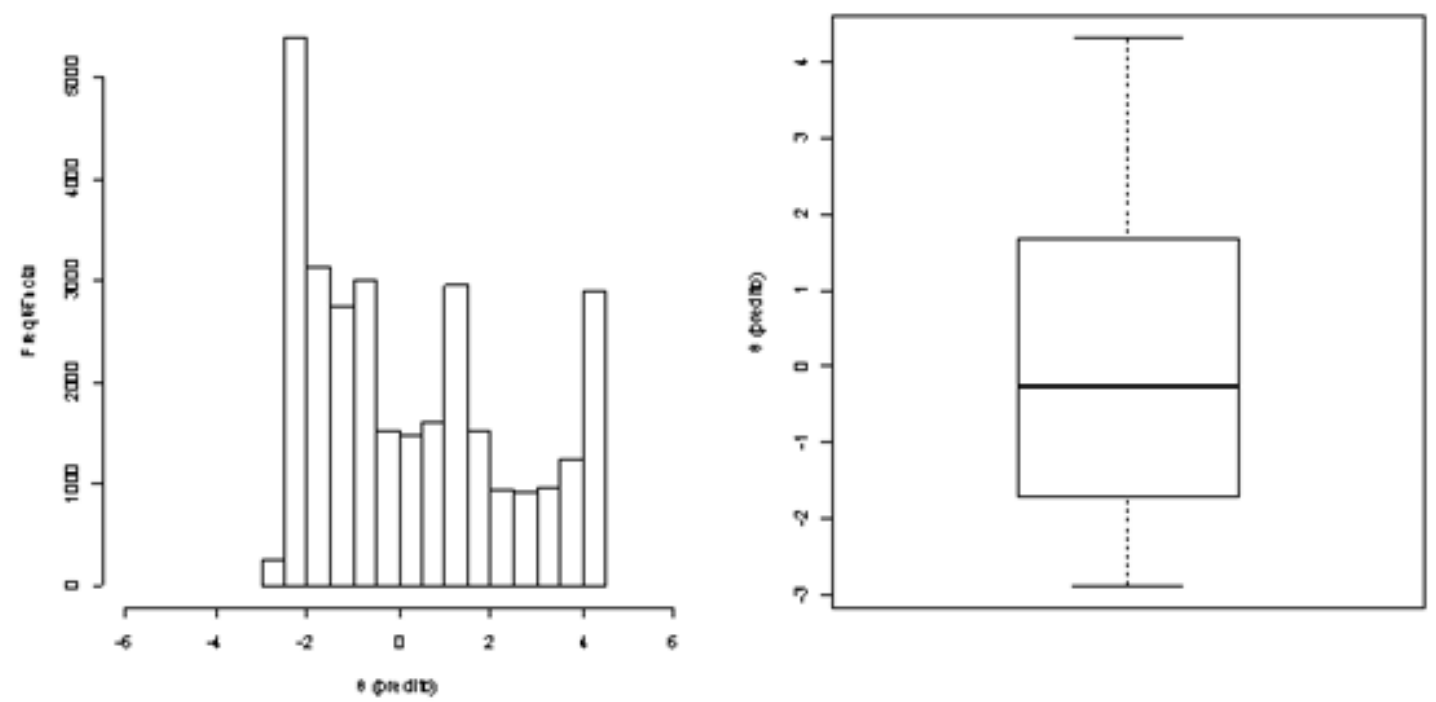

Figura 45. Distribuição dos valores da variável latente predita para os 30.619 fragmentos genéticos sob o modelo (4.3.2.2).

De maneira análoga à categorização dicotômica, as probabilidades de cada fragmento genético se expressar em cada item (condição experimental) são apresentadas nas Tabelas 12, 13, 14 e 15. Como exemplo, se utilizou os mesmos valores para a variável latente predita $(-4,-3,-2,-1,0,1,2,3,4)$ e suas correspondentes médias (para 5 réplicas) das probabilidades de expressão gênica em cada condição experimental, segundo as estimativas do modelo (4.3.2.2) apresentadas na Tabela 11.

Como pode ser visto, fragmentos genéticos com valores baixos $(-4,-3,-2$,) da variável latente têm alta probabilidade de se expressar pouco (nas categorias 1 ou 2). Do mesmo modo, fragmentos com valores altos $(0,1,2,3,4)$ da variável latente têm alta probabilidade de se expressar muito (nas categorias 3 ou 4).

Contudo, de maneira geral, como as curvas dos itens estão sobrepostas não é fácil distinguir itens por meio da variável latente, ou seja, para um dado valor da variável latente, o fragmento genético relacionado a esta tem probabilidades próximas para se expressar em qualquer condição.

Ressalta-se ainda que, ao se calcular as médias das probabilidades entre réplicas dentro de cada condição experimental, ficou mais difícil distinguir comportamentos diferentes dentre as condições experimentais já que as curvas CCI mostraram maiores diferenças entre réplicas dentro da mesma condição experimental do que entre réplicas 
de condições experimentais diferentes. Mais especificamente, por exemplo, a réplica $\mathrm{I}_{1}\left(\mathrm{SHR}^{+}\right)$mostrou um comportamento destoante das demais réplicas.

Apesar do pequeno valor discriminatório destas tabelas de probabilidades, uma utilização interessante pode ser, por exemplo, quando o médico tem interesse especial em um particular fragmento genético. Neste caso, associando-se a este fragmento genético o seu valor de variável latente (obtido por meio da TRI) se pode avaliar a ação deste fragmento em ratos nas condições experimentais avaliadas. Para ilustrar, suponha que o médico tem interesse em um particular fragmento que em decorrência da análise politômica possui valor de variável latente igual a -1 . Neste caso, de acordo com as Tabelas 12 e 14, é mais provável que este fragmento se expresse pouco independente da condição experimental, contudo, para o rato $\mathrm{CH} 4$ na condição sal há uma probabilidade não desprezível $(0,12)$ deste se expressar no nível 3, assim como, para o rato CH16 na condição basal $(0,10)$.

Tabela 12. Médias das probabilidades de expressão gênica em cada condição experimental após sal para valores latentes $-4,-3,-2,-1$ (os desvios padrão estão indicados entre parênteses).

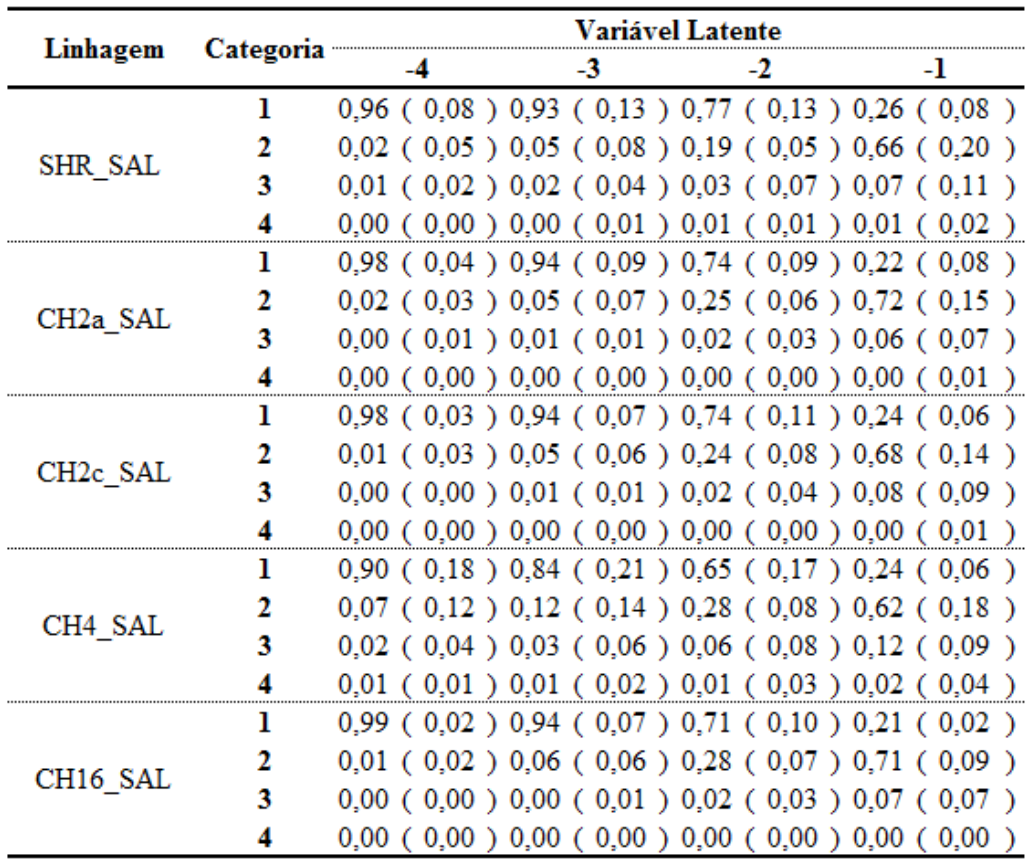


Tabela 13. Médias das probabilidades de expressão gênica em cada condição experimental após sal para valores latentes $0,1,2,3$ e 4 (os desvios padrão estão indicados entre parênteses).

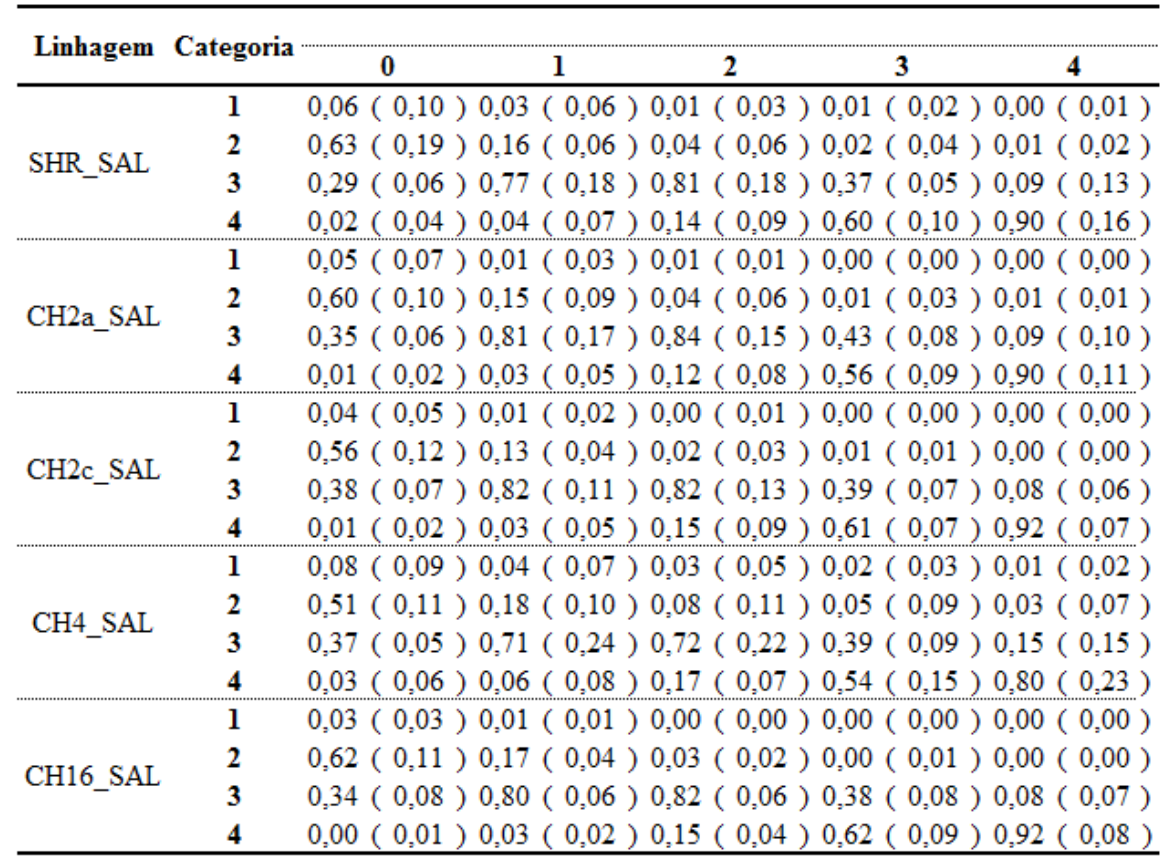

Tabela 14 Médias das probabilidades de expressão gênica em cada condição experimental basal para valores latentes $-4,-3,-2,-1$ (os desvios padrão estão indicados entre parênteses).

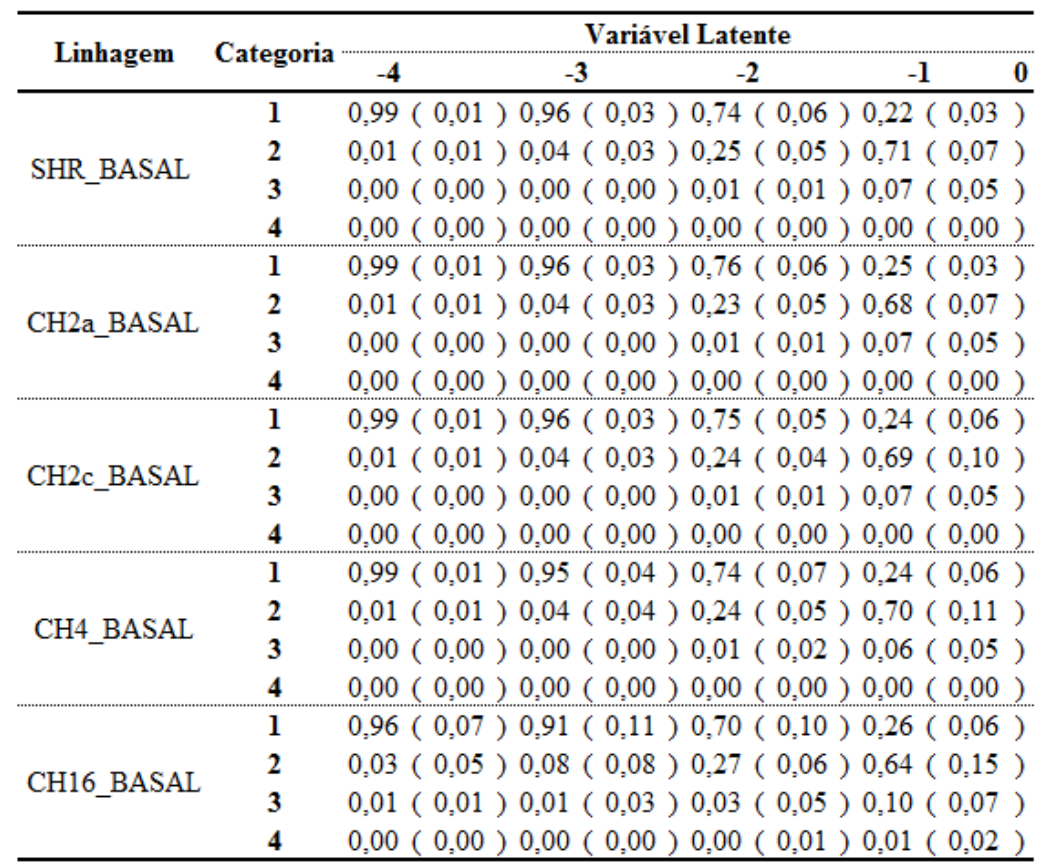


Tabela 15 Médias das probabilidades de expressão gênica em cada condição experimental basal para valores latentes $0,1,2,3$ e 4 (os desvios padrão estão indicados entre parênteses).

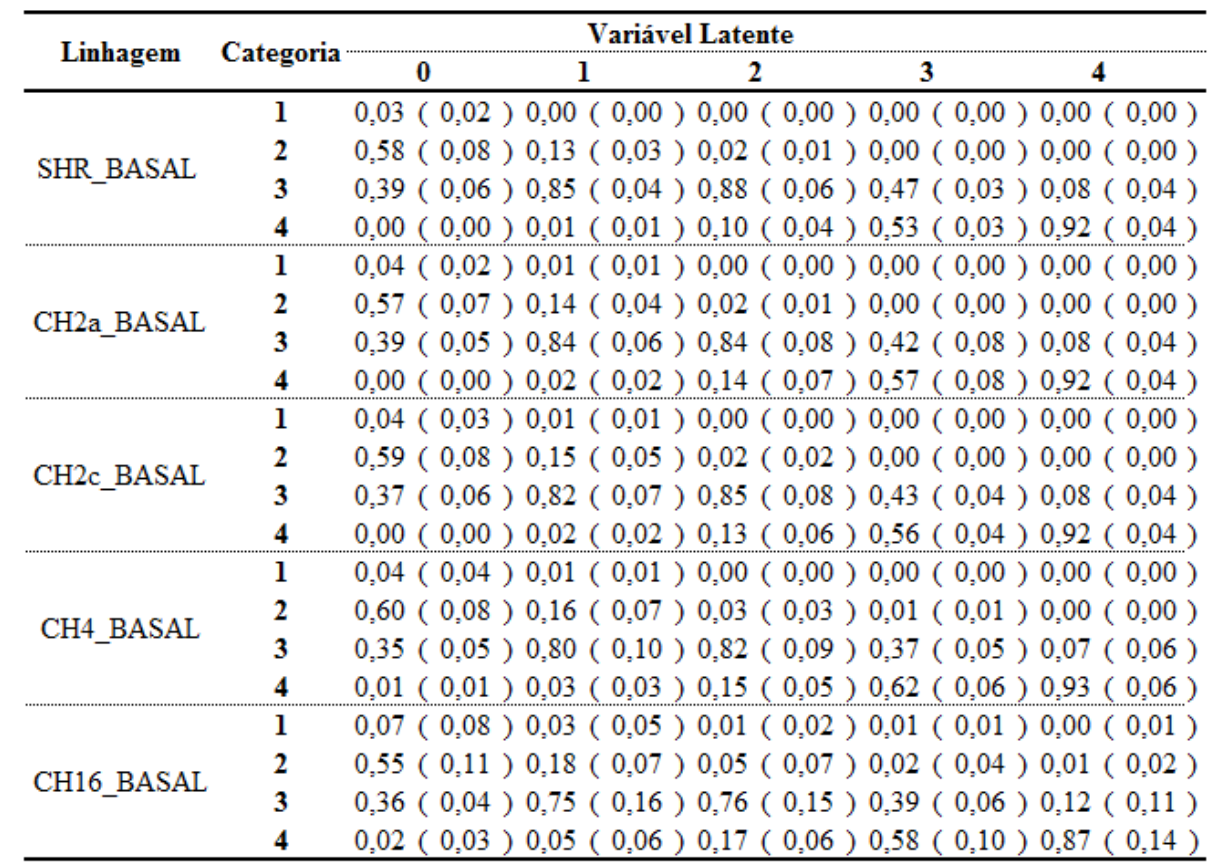

Para finalizar a análise sobre a base de dados do InCor, os resultados obtidos por meio da MAANOVA serão cruzados com os resultados obtidos na TRI. O objetivo ao se realizar esse cruzamento é verificar os valores estimados da variável latente dos fragmentos genéticos classificados como diferencialmente expressos na MAANOVA. A Tabela 16 traz estes resultados.

Tabela 16. Valor das variáveis latentes dos fragmentos DE pela MAANOVA.

\begin{tabular}{lllcc}
\hline Contraste & Fragmento & Quadrante & $\begin{array}{c}\text { Dicotômico } \\
\widehat{\boldsymbol{\theta}}_{\boldsymbol{j}}\end{array}$ & $\begin{array}{c}\text { Politômico } \\
\widehat{\boldsymbol{\theta}}_{\boldsymbol{j}}\end{array}$ \\
\hline$S H R^{+}-C H 2 a^{+}$ & GE16269 & $\mathrm{D}$ & $-0,070$ & 1,522 \\
$S H R^{+}-C H 2 c^{+}$ & $\mathrm{GE} 18021$ & $\mathrm{E}$ & $-0,383$ & $-2,186$ \\
$S H R^{+}-C H 2 c^{+}$ & $\mathrm{GE} 17089$ & $\mathrm{D}$ & 0,391 & 1,303 \\
$\mathrm{SHR}^{+}-\mathrm{CH} 2 c^{+}$ & $\mathrm{GE} 1275619$ & $\mathrm{D}$ & $-0,061$ & $-1,982$ \\
$\mathrm{SHR}^{+}-\mathrm{CH} 4^{+}$ & $\mathrm{GE} 1153031$ & $\mathrm{E}$ & $-0,425$ & $-1,339$ \\
$\mathrm{SHR}^{+}-\mathrm{CH} 4^{+}$ & $\mathrm{GE} 12617$ & $\mathrm{E}$ & 1,563 & $-2,161$ \\
$\mathrm{SHR}^{+}-\mathrm{CH} 4^{+}$ & $\mathrm{GE} 13974$ & $\mathrm{E}$ & $-0,425$ & 0,528 \\
$\mathrm{SHR}^{+}-\mathrm{CH} 4^{+}$ & $\mathrm{GE} 14452$ & $\mathrm{E}$ & $-0,425$ & 1,908
\end{tabular}




\begin{tabular}{|c|c|c|c|c|}
\hline $\mathrm{SHR}^{+}-\mathrm{CH}_{4}^{+}$ & GE1279991 & $\mathrm{E}$ & $-1,644$ & $-1,748$ \\
\hline $\mathrm{SHR}^{+}-\mathrm{CH}_{4}^{+}$ & GE13778 & $\mathrm{E}$ & $-0,425$ & $-0,481$ \\
\hline $\mathrm{SHR}^{+}-\mathrm{CH}^{+}$ & GE1190026 & $\mathrm{E}$ & - & - \\
\hline $\mathrm{SHR}^{+}-\mathrm{CH}_{4}^{+}$ & GE17444 & $\mathrm{E}$ & $-0,425$ & $-0,274$ \\
\hline $\mathrm{SHR}^{+}-\mathrm{CH}_{4}^{+}$ & GE14544 & $\mathrm{E}$ & $-0,425$ & 2,670 \\
\hline $\mathrm{SHR}^{+}-\mathrm{CH}_{4}^{+}$ & GE1232331 & $\mathrm{E}$ & - & - \\
\hline $\mathrm{SHR}^{+}-\mathrm{CH}_{4}^{+}$ & GE1155846 & $\mathrm{E}$ & - & - \\
\hline $\mathrm{SHR}^{+}-\mathrm{CH}_{4}^{+}$ & GE1238638 & $\mathrm{D}$ & 0,396 & 4,309 \\
\hline $\mathrm{SHR}^{+}-\mathrm{CH}_{4}^{+}$ & GE14422 & $\mathrm{D}$ & 0,397 & $-0,232$ \\
\hline $\mathrm{SHR}^{+}-\mathrm{CH}_{4}^{+}$ & GE1162596 & $\mathrm{D}$ & 0,434 & $-0,640$ \\
\hline $\mathrm{SHR}^{+}-\mathrm{CH} 16^{+}$ & GE1301531 & $\mathrm{E}$ & $-0,607$ & $-2,257$ \\
\hline $\mathrm{SHR}^{+}-\mathrm{CH} 16^{+}$ & GE17320 & $\mathrm{D}$ & 0,246 & 1,005 \\
\hline$S H R^{-}-C H 2 a^{-}$ & GE16269 & $\mathrm{D}$ & $-0,070$ & 1,522 \\
\hline$S H R^{-}-C H 2 c^{-}$ & GE18021 & $\mathrm{E}$ & $-0,383$ & $-2,186$ \\
\hline$S H R^{-}-C H 2 c^{-}$ & GE1284198 & $\mathrm{E}$ & $-0,242$ & $-0,883$ \\
\hline$S H R^{-}-C H 2 c^{-}$ & GE20039 & $\mathrm{E}$ & $-1,009$ & 1,562 \\
\hline$S H R^{-}-C H 2 c^{-}$ & GE17089 & $\mathrm{D}$ & 0,391 & 1,303 \\
\hline$S H R^{-}-C H 2 c^{-}$ & GE1212975 & $\mathrm{D}$ & $-0,432$ & $-1,000$ \\
\hline$S H R^{-}-C H 2 c^{-}$ & GE1275619 & $\mathrm{D}$ & $-0,061$ & $-1,982$ \\
\hline $\mathrm{SHR}^{-}-\mathrm{CH}_{4}^{-}$ & GE1153031 & $\mathrm{E}$ & $-0,425$ & $-1,339$ \\
\hline $\mathrm{SHR}^{-}-\mathrm{CH}^{-}$ & GE13974 & $\mathrm{E}$ & $-0,425$ & 0,528 \\
\hline $\mathrm{SHR}^{-}-\mathrm{CH}^{-}$ & GE14452 & $\mathrm{E}$ & $-0,425$ & 1,908 \\
\hline $\mathrm{SHR}^{-}-\mathrm{CH}_{4}^{-}$ & GE1190026 & $\mathrm{E}$ & - & - \\
\hline $\mathrm{SHR}^{-}-\mathrm{CH}_{4}^{-}$ & GE14544 & $\mathrm{E}$ & $-0,425$ & 2,670 \\
\hline $\mathrm{SHR}^{-}-\mathrm{CH}_{4}^{-}$ & GE13778 & $\mathrm{E}$ & $-0,425$ & $-0,481$ \\
\hline $\mathrm{SHR}^{-}-\mathrm{CH}_{4}^{-}$ & GE17444 & $\mathrm{E}$ & $-0,425$ & $-0,274$ \\
\hline $\mathrm{SHR}^{-}-\mathrm{CH}_{4}^{-}$ & GE1238638 & $\mathrm{D}$ & 0,396 & 4,309 \\
\hline$S H R^{-}-\mathrm{CH}_{4}^{-}$ & GE14422 & $\mathrm{D}$ & 0,397 & $-0,232$ \\
\hline $\mathrm{SHR}^{-}-\mathrm{CH}_{4}^{-}$ & GE1162596 & $\mathrm{D}$ & 0,434 & $-0,640$ \\
\hline$S H R^{-}-C H 16^{-}$ & GE17320 & $\mathrm{D}$ & 0,246 & 1,005 \\
\hline $\mathrm{CH} 16^{+}-\mathrm{CH} 16^{-}$ & GE1120119 & $\mathrm{E}$ & - & - \\
\hline $\mathrm{CH} 16^{+}-\mathrm{CH} 16^{-}$ & GE1202435 & $\mathrm{D}$ & $-1,644$ & $-2,145$ \\
\hline $\mathrm{CH} 16^{+}-\mathrm{CH} 16^{-}$ & GE17753 & $\mathrm{D}$ & - & - \\
\hline
\end{tabular}

O esforço na construção da Tabela 16 foi no sentido de se caracterizar o valor da variável latente dos fragmentos genéticos identificados como DE (identificados pela análise MAANOVA) com o particular tipo de contraste associado a este fragmento. Todavia, tal caracterização parece indicar que os resultados das duas análises não são concordantes. Os diferentes fragmentos dentro de um mesmo tipo de contraste apresentaram valores de variável latente muitas vezes opostos como, por exemplo, para 
o contraste $\mathrm{SHR}^{+}-\mathrm{CH}_{4}^{+}$onde os valores da variável latente são muito discrepantes variando de $-2,16$ até 2,67 .

Neste sentido se questiona a validade de se buscar uma concordância entre os resultados de duas metodologias que envolvem pressupostos tão diferentes. Talvez o mais importante seja avaliar o quanto de informação pode ser extraída individualmente de cada análise, bem como, as limitações de uso destas informações. Por exemplo, neste trabalho se notou através das análises MAANOVA e TRI que a variabilidade entre réplicas é muito maior quando comparada à variabilidade entre tratamentos. Todavia, na MAANOVA a variabilidade decorrente entre as diferentes réplicas pode ser tratada a partir de um efeito de bloco considerado no modelo. Por outro lado, na análise da TRI nenhuma consideração de tal efeito foi realizada sendo, talvez, uma alternativa de análise a realização da análise da TRI a partir das respostas ajustadas por um modelo de MAANOVA considerando o efeito de bloco. 


\section{Considerações finais}

A técnica de Microarrays é de fato uma poderosa ferramenta biotecnológica para se trabalhar com informações genéticas, ampliando de maneira interessante a visão com a qual, por exemplo, questões na Medicina são estudadas, respondidas e interpretadas. Contudo, talvez por decorrência de sua complexidade, esta técnica ainda requer que inúmeros esforços científicos sejam empregados à mesma na tentativa de, por exemplo, corrigir, ajustar e interpretar a informação que se almeja obter por meio desta técnica: os valores de expressão gênica.

Neste sentido, desde a sua elaboração, continuamente, metodologias de análise estatística tem sido desenvolvidas para, dentre outras coisas, por exemplo, atenuar ou excluir as inúmeras fontes de variação presentes nos experimentos de Microarrays, as quais, de certa forma, prejudicam a extração das importantes informações contidas nos valores de expressão gênica. Outro problema natural aos experimentos de Microarrays está relacionado aos múltiplos testes usualmente aplicados para se detectar fragmentos genéticos diferencialmente expressos sob diferentes condições experimentais avaliadas.

Apesar de haver diversas metodologias estatísticas disponíveis para se tentar eliminar os problemas inerentes à técnica de Microarrays, algumas dificuldades como lidar com as fontes de variação desconhecidas ainda persistem. Desta forma, neste trabalho, se buscou aplicar uma metodologia clássica, bem como, investigar o potencial de uma nova abordagem, via a TRI. Neste sentido, uma das motivações na aplicação da TRI é controlar o efeito das fontes de variações desconhecidas por meio da categorização dos valores de expressão gênica, o que de certo modo também é uma alternativa à análise de dados assimétricos. Contudo, a principal motivação é a construção de uma escala de expressão gênica, considerando que a medida proveniente de experimentos de Microarrays é indireta.

Dos resultados encontrados neste trabalho, podemos destacar a TRI como uma metodologia que pode ser aplicada na análise de dados de Microarrays, entretanto, as limitações encontradas nos resultados de nossa particular aplicação podem ser consideradas como decorrentes, principalmente, da não possibilidade de se planejar melhor a escolha dos itens. 
Em condições ideais, uma aplicação da TRI a experimentos de Microarrays deveria se iniciar com a calibração dos itens, ou seja, selecionar um conjunto de situações experimentais que permita a construção de uma escala de valores de expressão gênica capaz de discriminar diferentes fragmentos genético, bem como, agregar informação sobre toda a escala latente. Em nossa aplicação, um problema encontrado foi a redundância entre os item avaliados, os quais, de certo modo, possibilitaram a construção de informação a uma pequena região da escala latente. Como alternativa a este problema, pesquisas deveriam ser investidas no sentido de se realizar perturbações nos animais tais que propiciassem a seleção de itens informativos segundo os pressupostos da TRI, isto é, itens posicionados em toda a escala. Se para delineamentos com animais tal estratégia requer alto custo e, possivelmente, muito tempo para geração de animais congênicos, em delineamentos com plantas esta restrição não acontece, já que a obtenção de plantas transgênicas, com diferentes modificações no genoma é atualmente viável a um baixo custo e em curto tempo.

Outro ponto que deve ser destacado na aplicação da TRI a Microarrays diz respeito à possibilidade de se trabalhar com modelos com mais de uma dimensão para a variável latente. Considerando os dados analisados neste trabalho a aplicação da análise fatorial indica que, principalmente no da categorização dicotômica da variável de expressão gênica, é esperado que a expressão gênica esteja associada com mais de um fator (ver Apêndice C). Li \& Hong (2001) propuseram uma alternativa de análise na qual se realiza o ajuste de um específico modelo da TRI para cada uma das situações experimentais em estudo. Como resultado desta conjectura de análise, cada fragmento genético terá um conjunto de fatores latentes estimados. Por exemplo, para o conjunto de dados de animais congênitos, se realizariam 10 diferentes análises da TRI contendo 5 itens cada (para o conjunto de itens $\mathrm{I}_{1}\left(\mathrm{SHR}^{+}\right), \mathrm{I}_{11}\left(\mathrm{SHR}^{+}\right), \mathrm{I}_{21}\left(\mathrm{SHR}^{+}\right), \mathrm{I}_{31}\left(\mathrm{SHR}^{+}\right) \mathrm{e}$ $\mathrm{I}_{41}\left(\mathrm{SHR}^{+}\right)$se estimaria um primeiro fator latente, digamos $\theta_{j}^{1}$, para o conjunto de itens $\mathrm{I}_{6}\left(\mathrm{SHR}^{-}\right), \mathrm{I}_{16}\left(\mathrm{SHR}^{-}\right), \mathrm{I}_{26}\left(\mathrm{SHR}^{-}\right) \mathrm{I}_{36}\left(\mathrm{SHR}^{-}\right)$e $\mathrm{I}_{46}\left(\mathrm{SHR}^{-}\right)$se estimaria um segundo fator latente, digamos $\theta_{j}^{2}$, e assim por diante até se obter $\left.\theta_{j}^{10}, \ldots, \theta_{j}^{10}\right)$. Contudo, neste trabalho ficou evidente a existência de maior variabilidade entre réplicas (que correspondem aos blocos), o que de certo modo poderia invalidar a aplicação desta metodologia sendo, talvez, mais razoável a aplicação da mesma em delineamentos experimentais nos quais todos os tratamentos em estudo tenham sido hibridizados conjuntamente. 


\section{A. Distribuição dos valores de expressão gênica - animais congênicos}
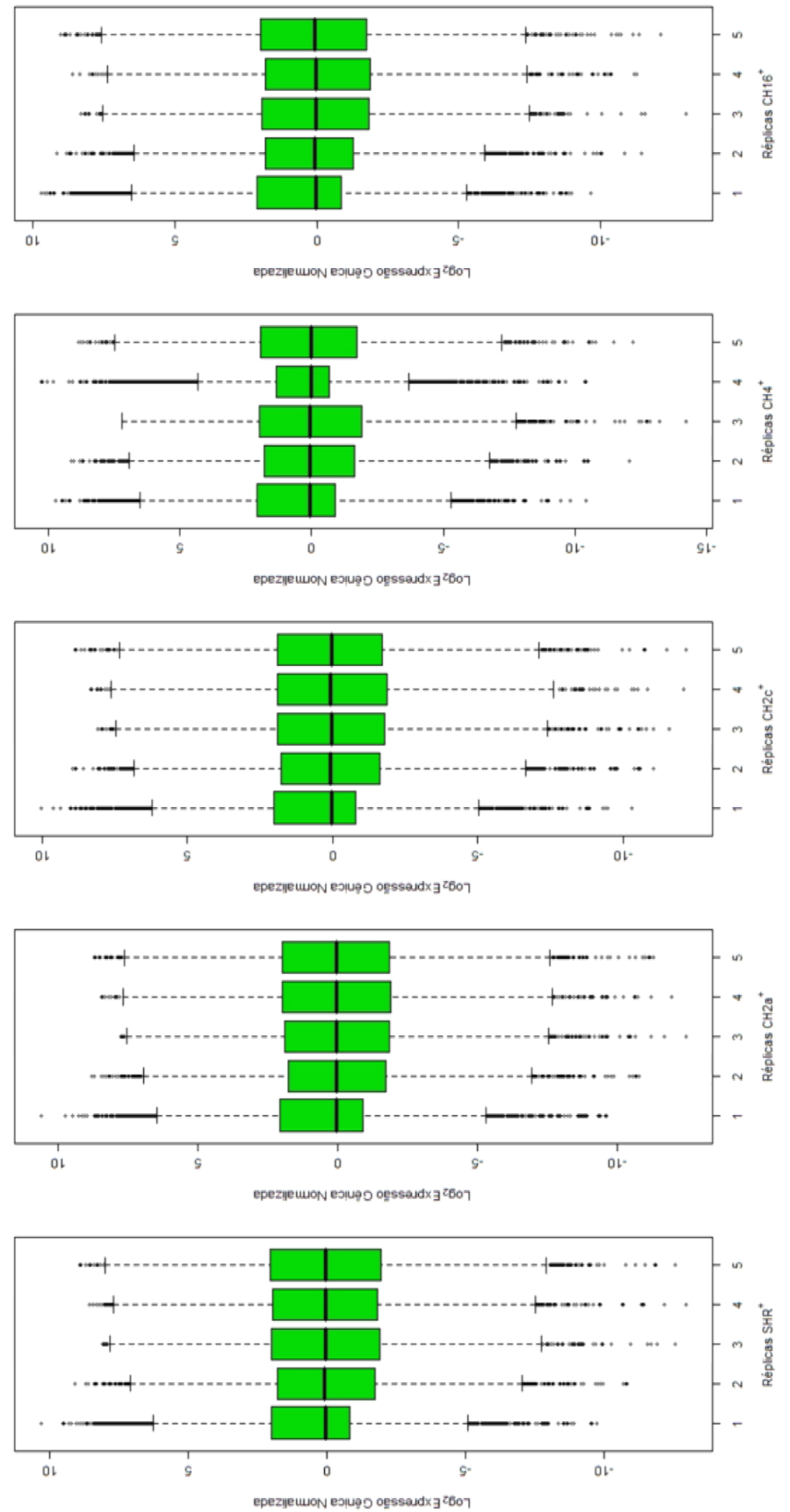

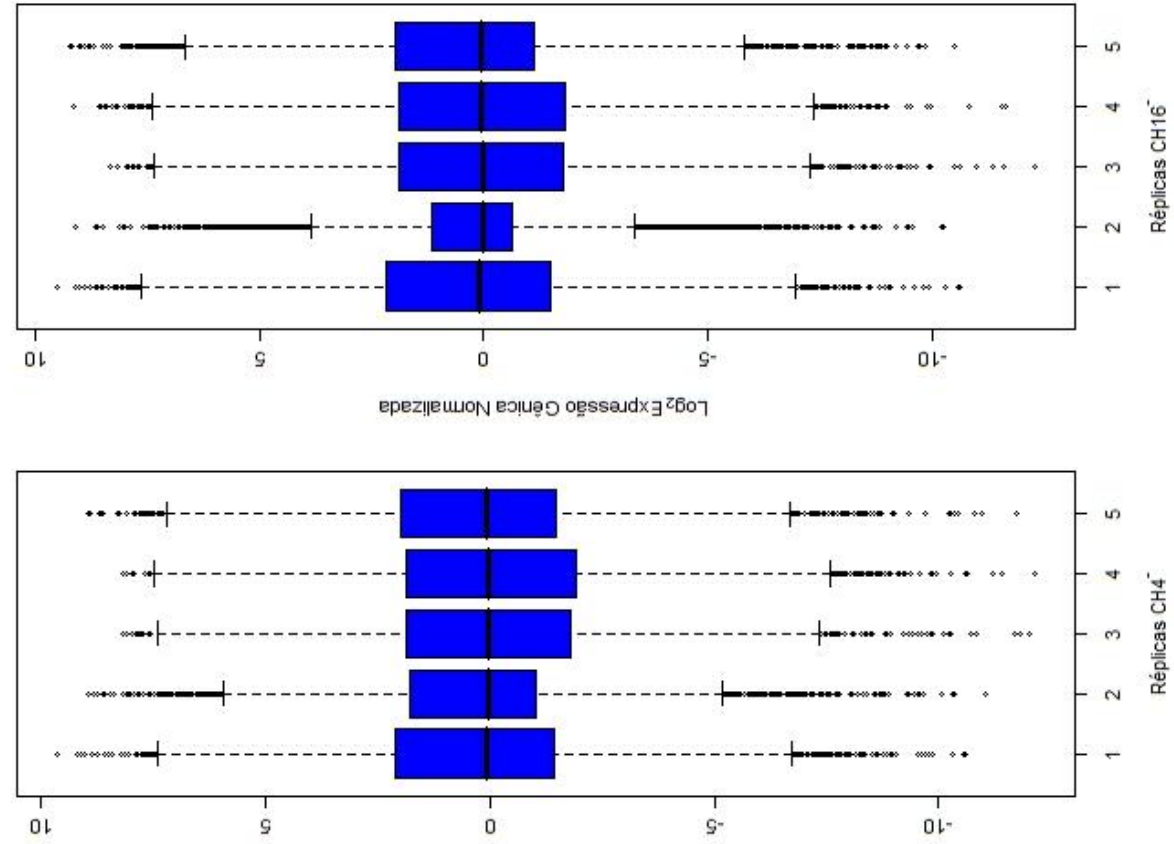

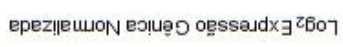

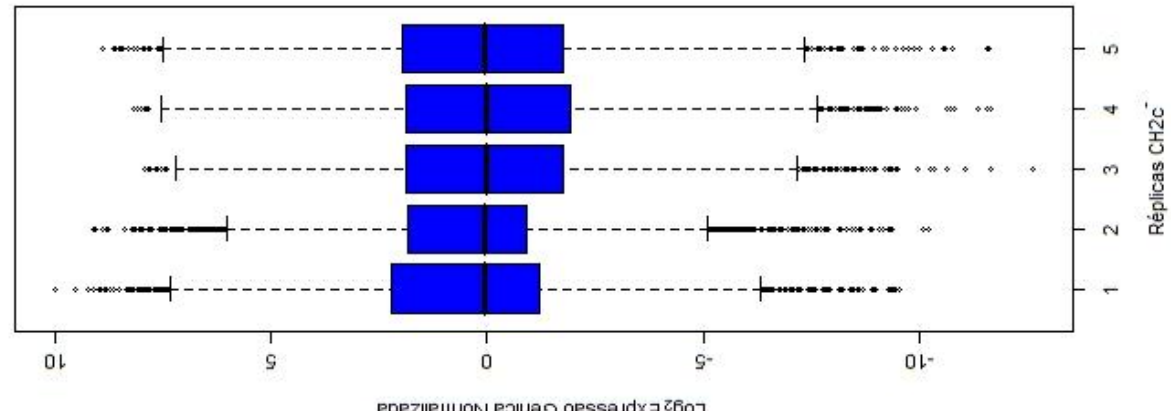

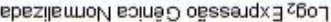

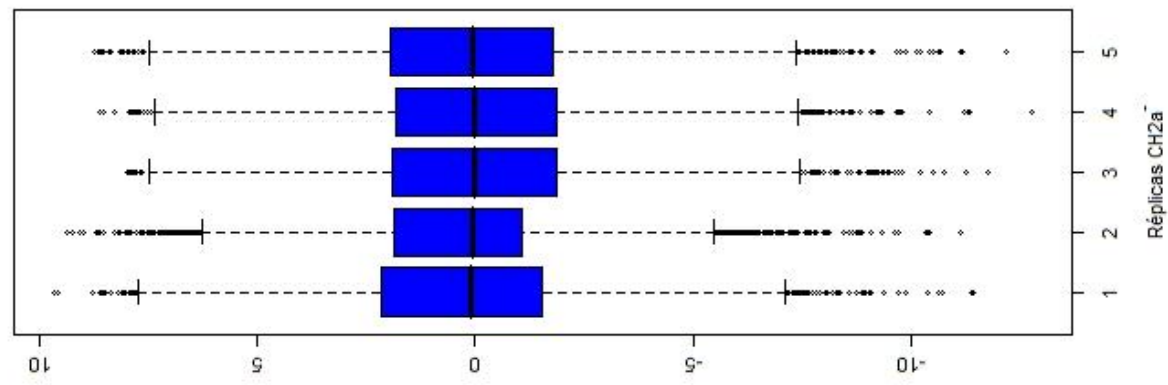

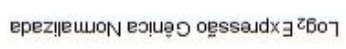

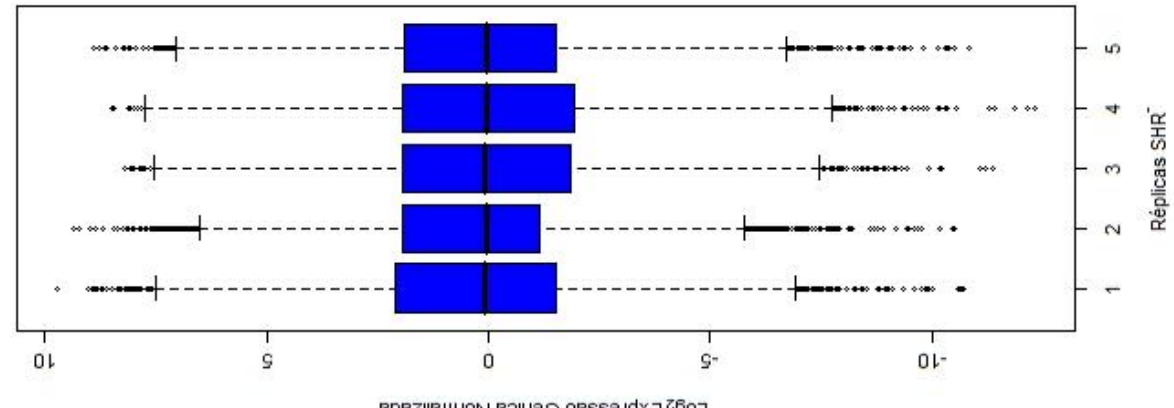

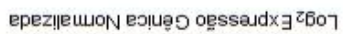




\section{B. CCI - animais congênicos - Modelo Samejima}
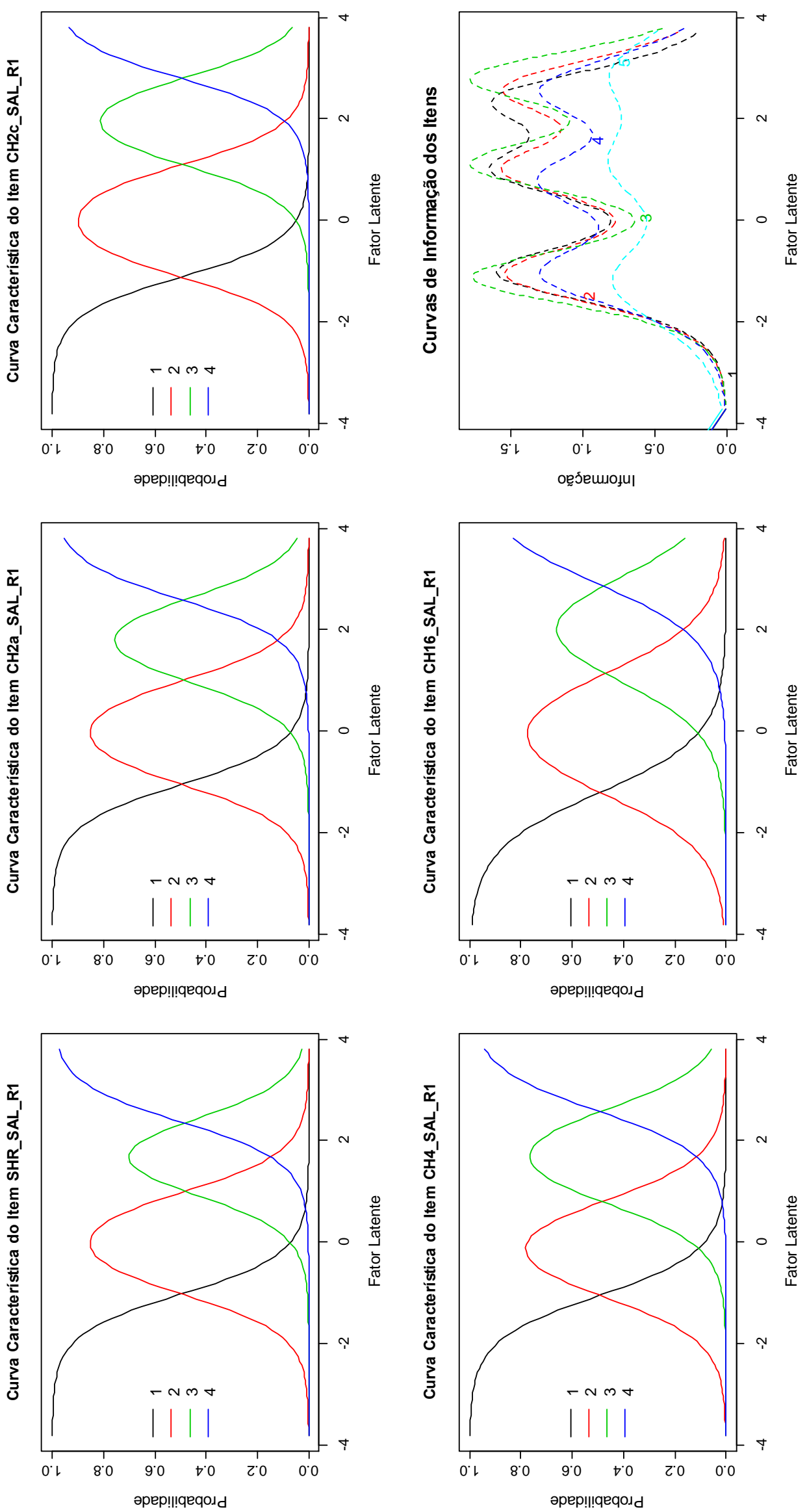

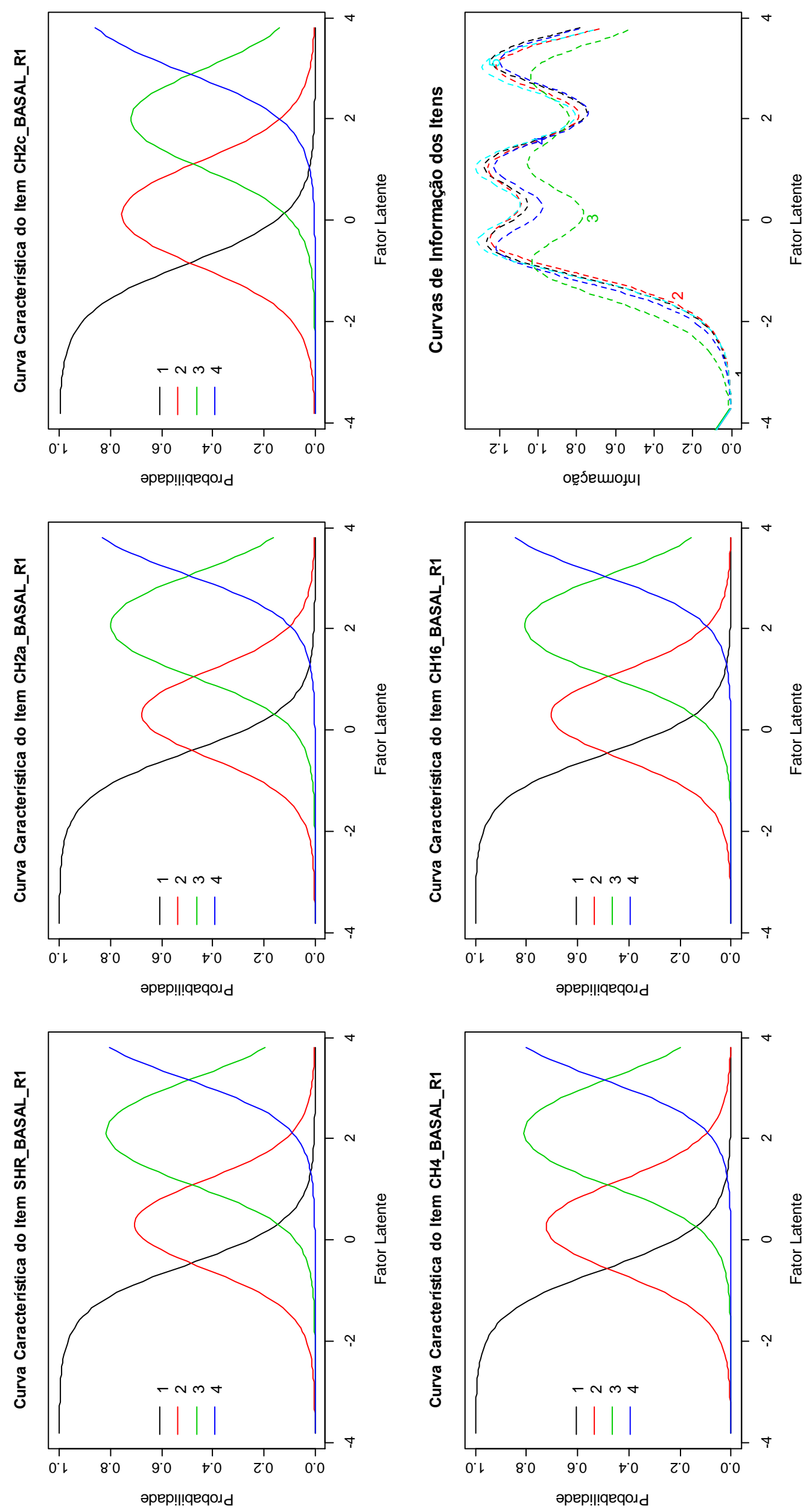

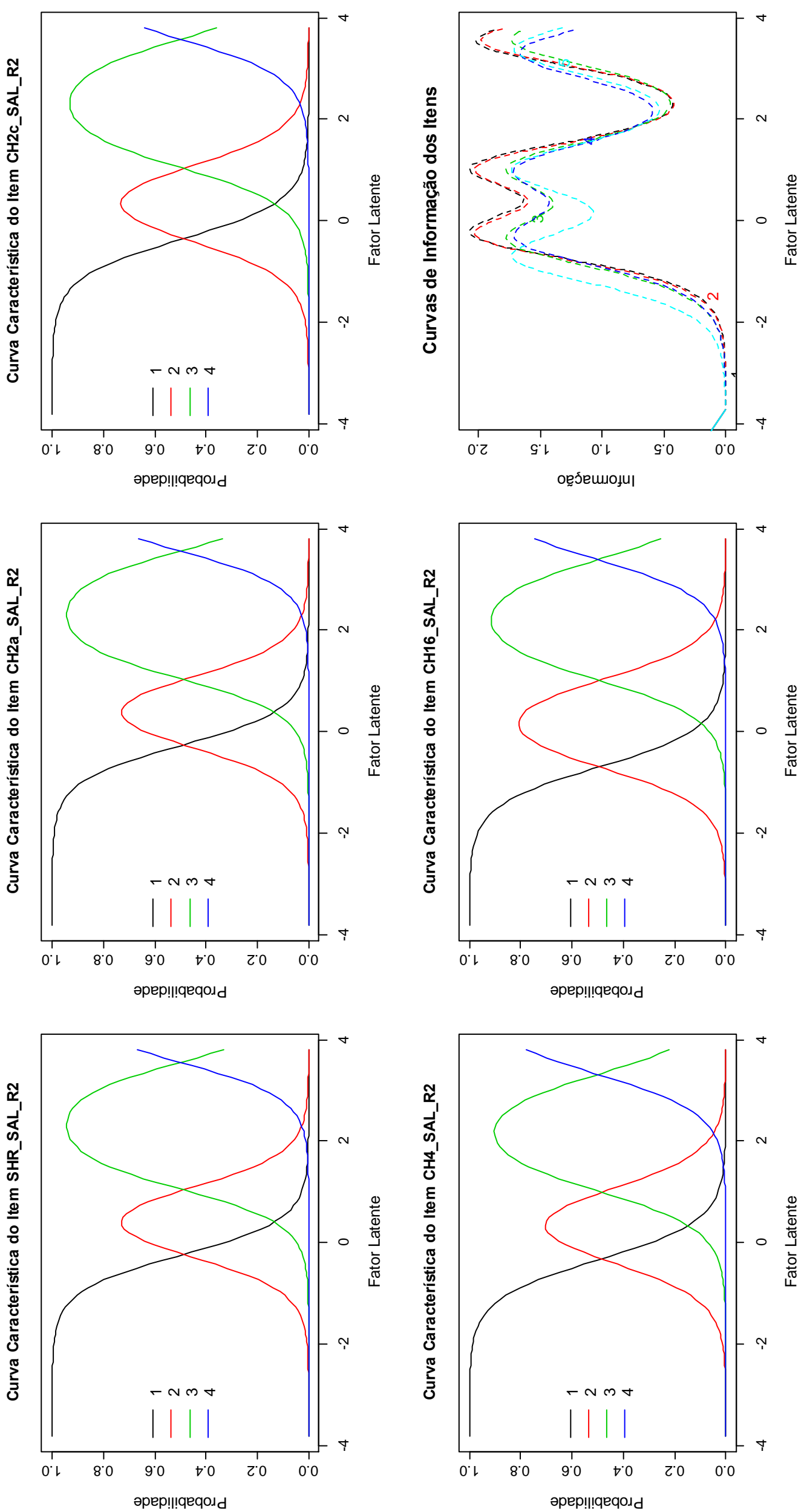

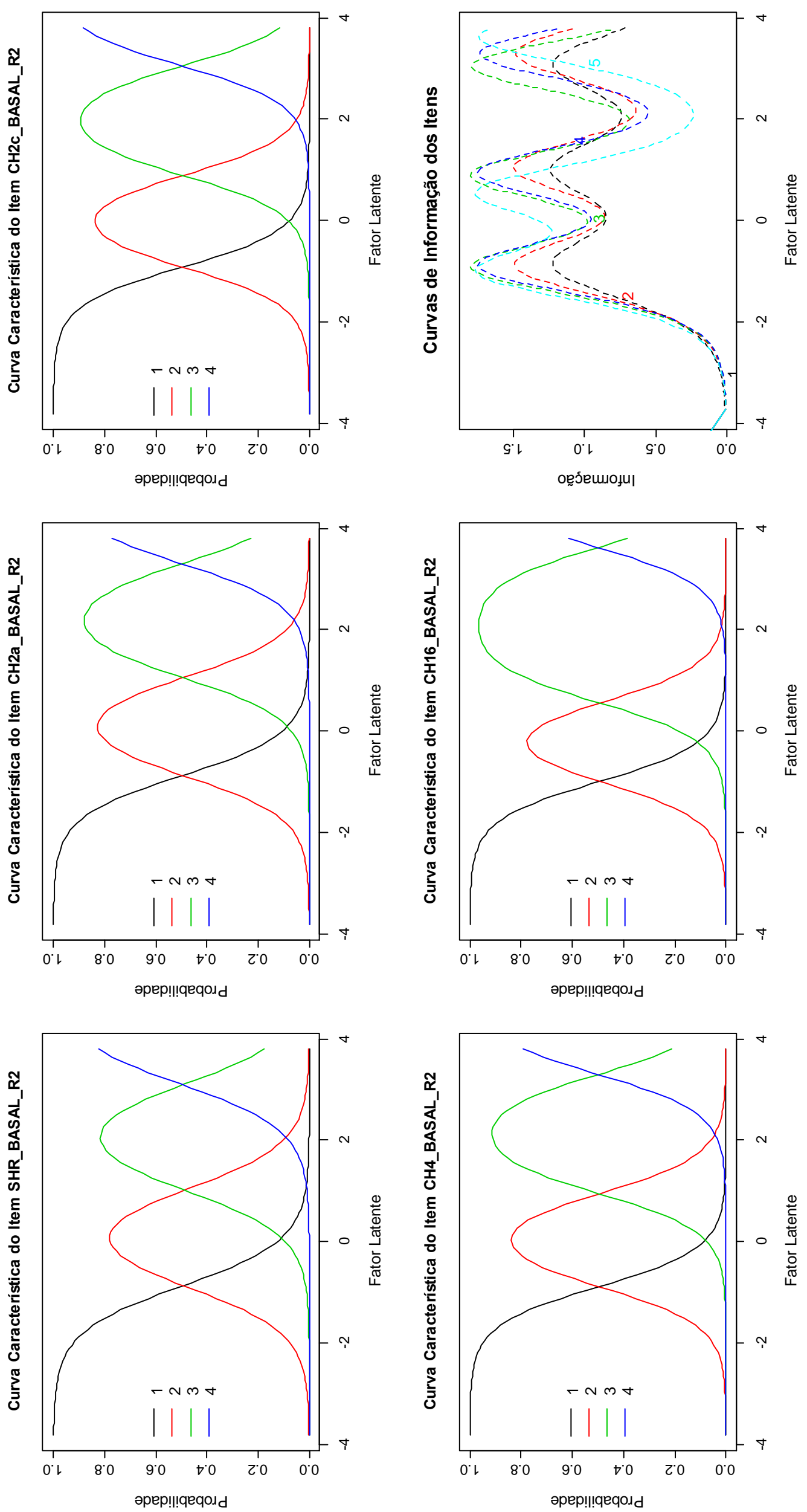

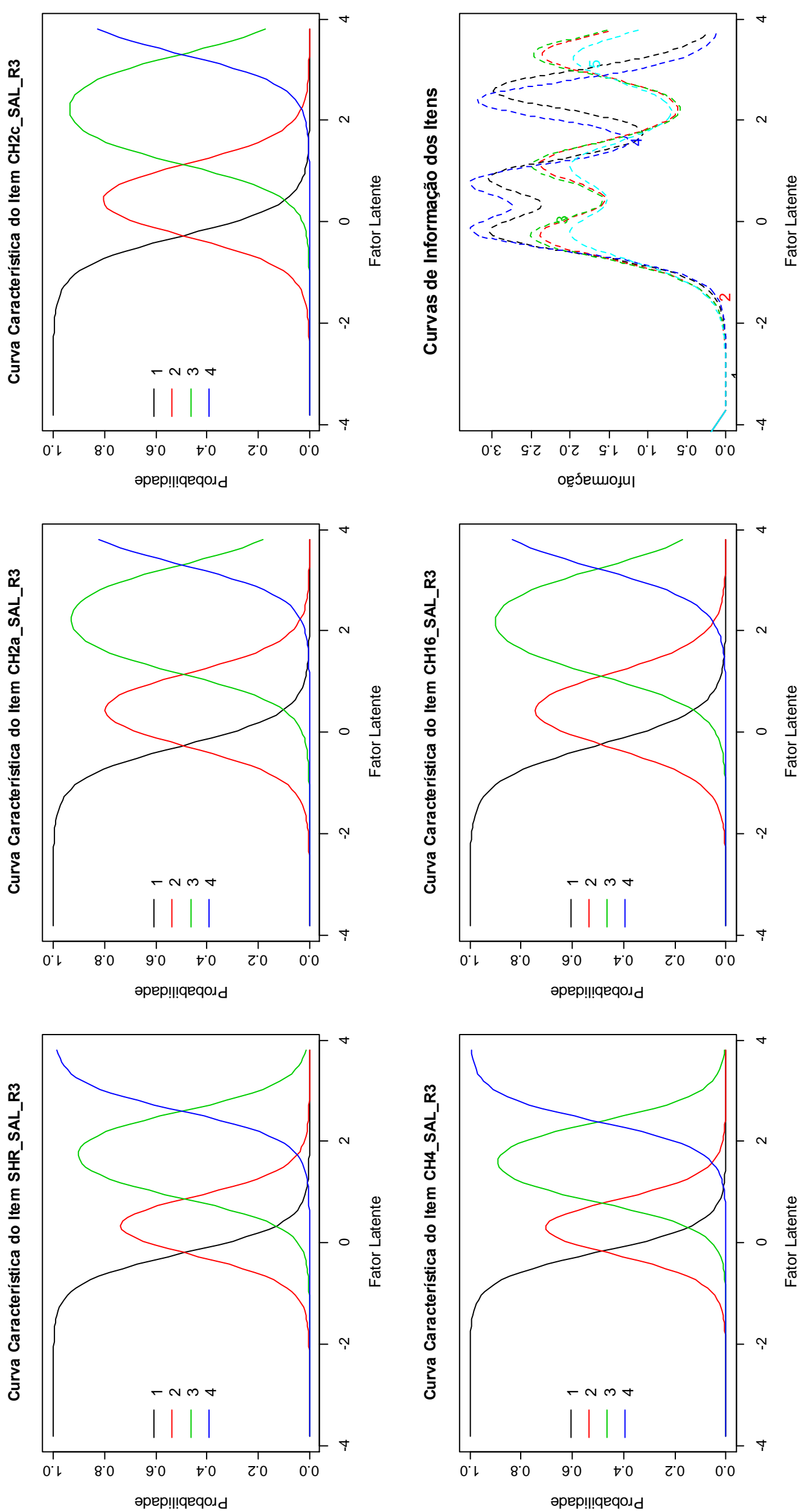

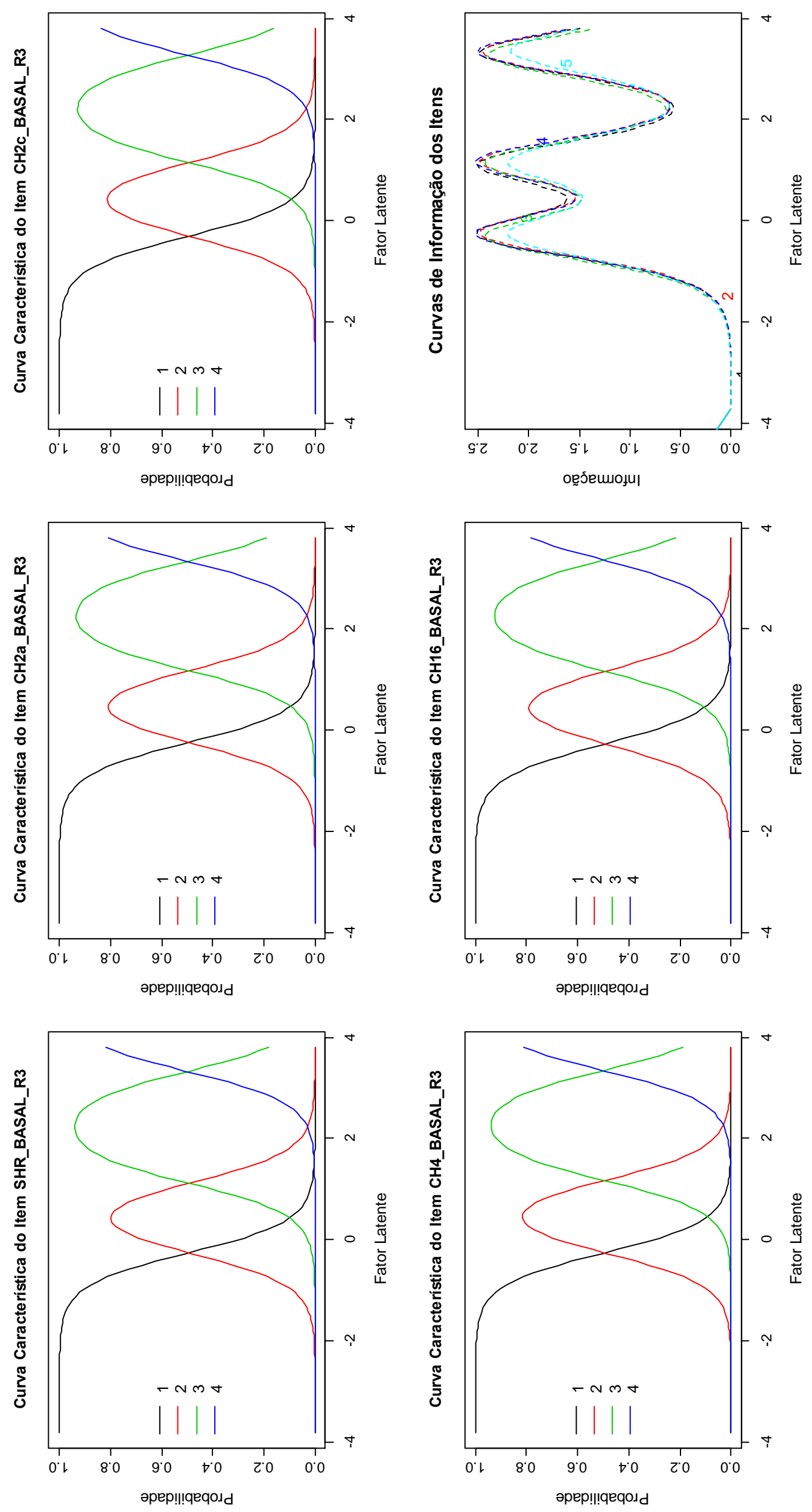

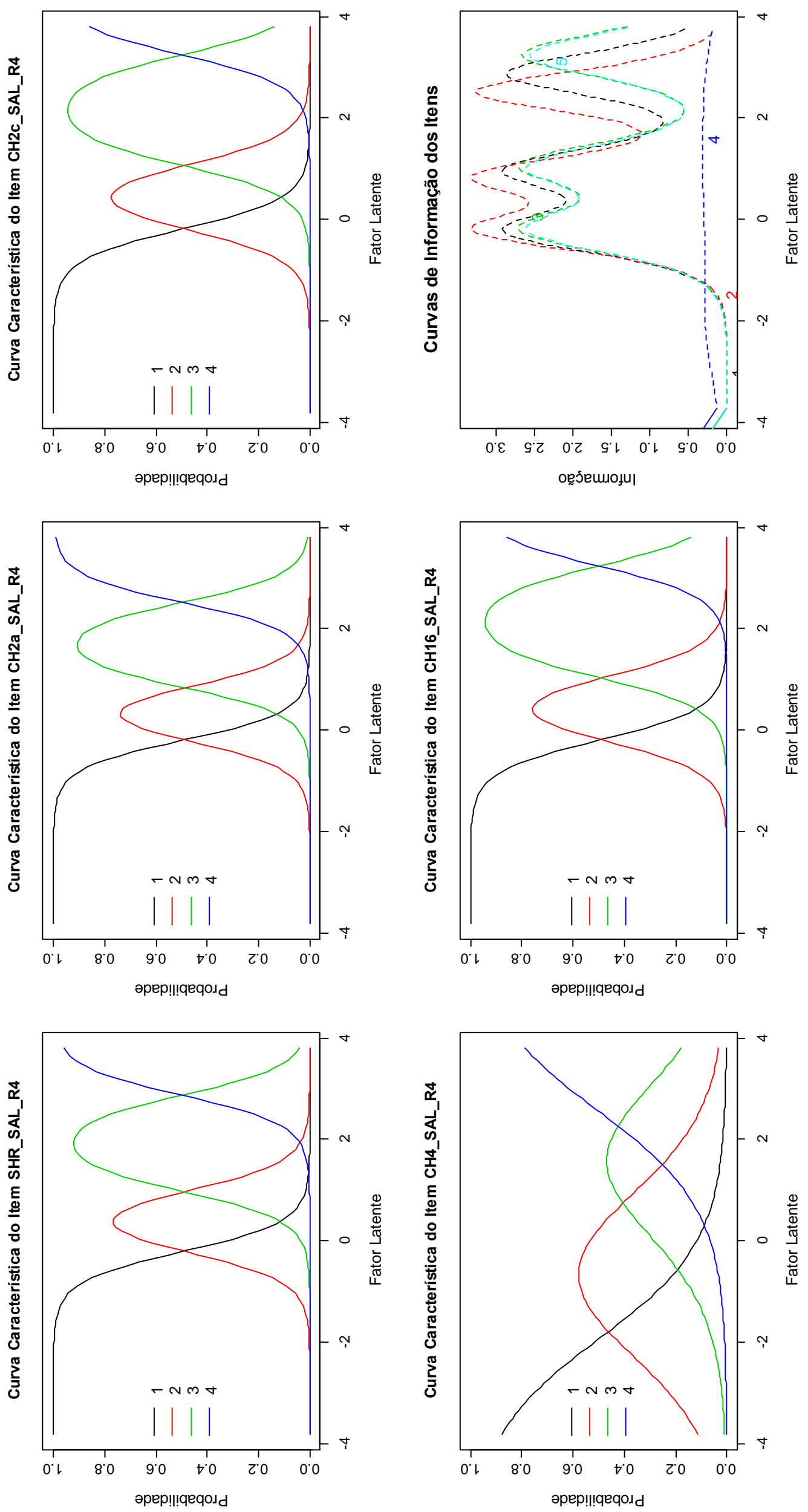

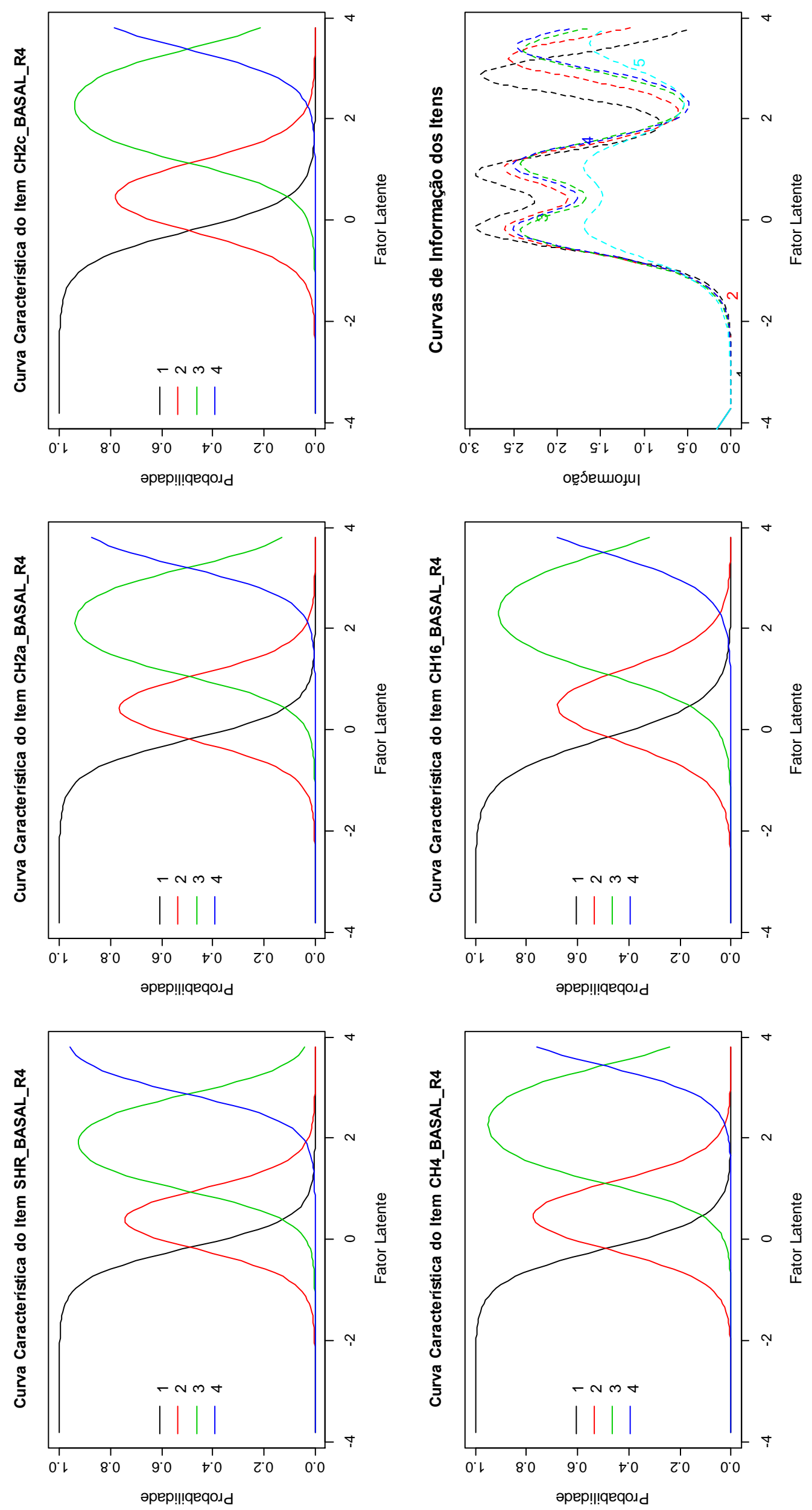

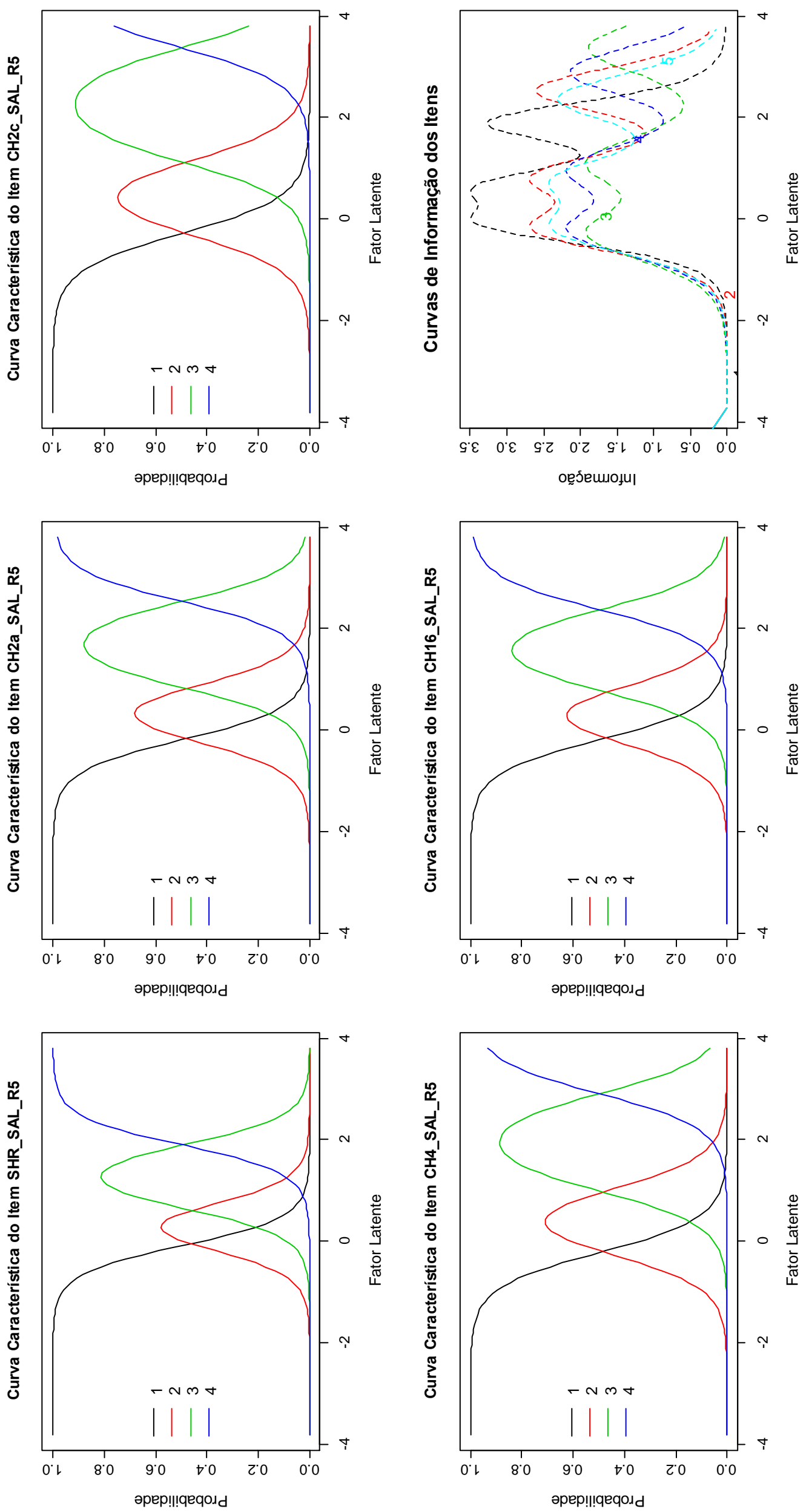

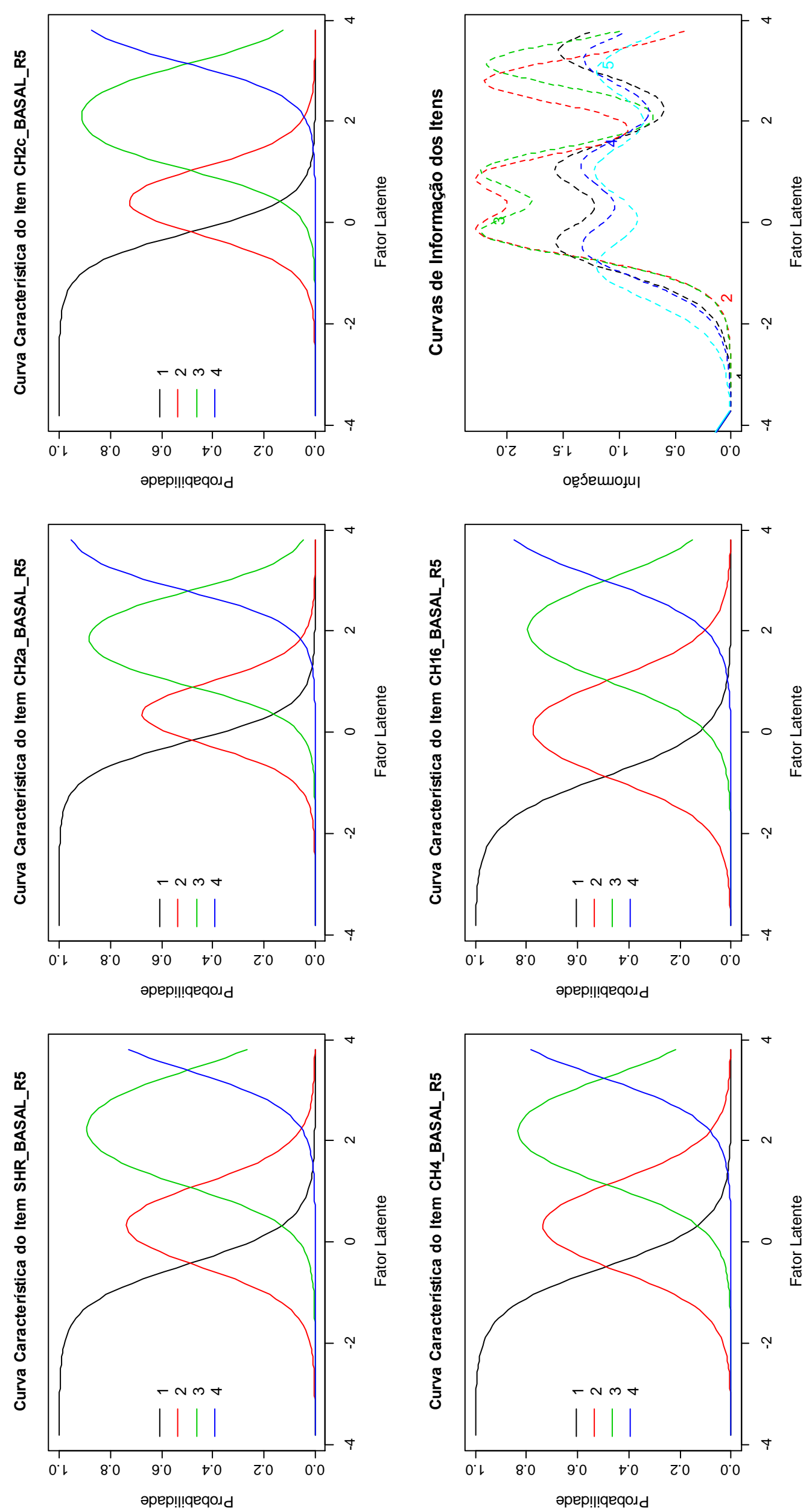


\section{Análise Fatorial - Animais Congênicos}

Com o propósito de se explorar a dimensionalidade dos dados de expressão gênica considerados neste trabalho se aplicou ao mesmo a técnica de Análise Fatorial AF. Na Tabela 17 são apresentados os resultados da AF conduzida para os dados contínuos de expressão gênica normalizado pelo método da mediana e, posteriormente, nas Tabelas 18 e 19 os resultados da AF conduzida para os dados de expressão gênica normalizados pelo método da mediana categorizados segundo o critério dicotômico e critério politômico anteriormente apresentados. Para melhor interpretação dos fatores aplicou-se a rotação varimax.

Tabela 17. Análise Fatorial - dados originais de expressão gênica.

Análise Fatorial - Animais congênicos (ordenação pelo fator 1)

\begin{tabular}{llcccc}
\multicolumn{1}{c}{ Exposição } & Linhagem & Bloco & Fator 1 & Fator 2 & Fator 3 \\
\hline SAL & CH4 & BL3 & 0,850 & 0,306 & 0,349 \\
BASAL & CH2a & BL3 & 0,836 & 0,329 & 0,370 \\
BASAL & CH2c & BL3 & 0,834 & 0,341 & 0,369 \\
BASAL & CH4 & BL3 & 0,832 & 0,340 & 0,368 \\
BASAL & SHR & BL3 & 0,830 & 0,352 & 0,363 \\
SAL & CH2a & BL3 & 0,829 & 0,328 & 0,372 \\
SAL & CH2c & BL3 & 0,828 & 0,346 & 0,370 \\
SAL & SHR & BL3 & 0,825 & 0,351 & 0,372 \\
BASAL & CH2c & BL4 & 0,819 & 0,300 & 0,398 \\
SAL & CH16 & BL3 & 0,810 & 0,358 & 0,361 \\
BASAL & CH4 & BL4 & 0,806 & 0,356 & 0,373 \\
SAL & CH2a & BL4 & 0,804 & 0,374 & 0,395 \\
BASAL & CH16 & BL3 & 0,803 & 0,344 & 0,405 \\
SAL & SHR & BL4 & 0,801 & 0,375 & 0,394 \\
BASAL & CH2a & BL4 & 0,798 & 0,373 & 0,384 \\
SAL & CH2c & BL4 & 0,795 & 0,377 & 0,395 \\
SAL & CH16 & BL4 & 0,793 & 0,386 & 0,386 \\
BASAL & SHR & BL4 & 0,787 & 0,368 & 0,405 \\
SAL & CH2a & BL5 & 0,752 & 0,417 & 0,425 \\
BASAL & CH16 & BL4 & 0,747 & 0,386 & 0,402 \\
SAL & SHR & BL2 & 0,745 & 0,436 & 0,397 \\
SAL & SHR & BL5 & 0,743 & 0,407 & 0,437 \\
SAL & CH2a & BL2 & 0,734 & 0,454 & 0,395
\end{tabular}




\begin{tabular}{|c|c|c|c|c|c|}
\hline SAL & CH4 & BL5 & 0,727 & 0,441 & 0,427 \\
\hline BASAL & $\mathrm{CH} 2 \mathrm{c}$ & BL5 & 0,726 & 0,388 & 0,476 \\
\hline SAL & $\mathrm{CH} 2 \mathrm{c}$ & BL5 & 0,721 & 0,440 & 0,437 \\
\hline SAL & CH16 & BL5 & 0,712 & 0,463 & 0,424 \\
\hline SAL & $\mathrm{CH} 2 \mathrm{c}$ & BL2 & 0,711 & 0,460 & 0,410 \\
\hline BASAL & СН2a & BL5 & 0,708 & 0,453 & 0,432 \\
\hline SAL & CH4 & BL2 & 0,705 & 0,447 & 0,419 \\
\hline BASAL & SHR & BL5 & 0,689 & 0,437 & 0,461 \\
\hline SAL & CH16 & BL2 & 0,680 & 0,500 & 0,397 \\
\hline BASAL & CH2a & BL1 & 0,663 & 0,336 & 0,572 \\
\hline BASAL & CH4 & BL5 & 0,659 & 0,453 & 0,470 \\
\hline BASAL & CH16 & BL1 & 0,656 & 0,363 & 0,575 \\
\hline BASAL & SHR & BL1 & 0,653 & 0,367 & 0,571 \\
\hline BASAL & CH4 & BL1 & 0,652 & 0,364 & 0,567 \\
\hline BASAL & CH16 & BL5 & 0,647 & 0,480 & 0,438 \\
\hline BASAL & CH2a & BL2 & 0,639 & 0,560 & 0,363 \\
\hline BASAL & SHR & BL2 & 0,637 & 0,548 & 0,391 \\
\hline BASAL & CH4 & BL2 & 0,616 & 0,579 & 0,355 \\
\hline BASAL & $\mathrm{CH} 2 \mathrm{c}$ & BL1 & 0,615 & 0,366 & 0,601 \\
\hline BASAL & $\mathrm{CH} 2 \mathrm{c}$ & BL2 & 0,605 & 0,568 & 0,385 \\
\hline SAL & SHR & BL1 & 0,573 & 0,208 & 0,563 \\
\hline SAL & CH4 & BL1 & 0,556 & 0,491 & 0,521 \\
\hline SAL & CH2a & BL1 & 0,540 & 0,276 & 0,629 \\
\hline SAL & CH16 & BL1 & 0,532 & 0,513 & 0,521 \\
\hline SAL & $\mathrm{CH} 2 \mathrm{c}$ & BL1 & 0,517 & 0,394 & 0,608 \\
\hline SAL & CH4 & BL4 & 0,478 & 0,402 & 0,270 \\
\hline BASAL & CH16 & BL2 & 0,478 & 0,564 & 0,280 \\
\hline & & & 25,720 & 8,524 & 9,536 \\
\hline$P=1$ & نiâ & & $51,4 \%$ & $17,0 \%$ & $19,1 \%$ \\
\hline ariância a & Ilada & & $51,4 \%$ & $68,5 \%$ & $87,6 \%$ \\
\hline
\end{tabular}

Tabela 18. Análise Fatorial - dados de expressão gênica após categorização dicotômica.

Análise Fatorial - Animais congênicos (ordenação pelo fator 1)

\begin{tabular}{llcccc} 
Exposição & Linhagem & Bloco & Fator 1 & Fator 2 & Fator 3 \\
\hline BASAL & CH2a & BL3 & 0,782 & 0,412 & 0,388 \\
BASAL & CH4 & BL3 & 0,779 & 0,390 & 0,427 \\
SAL & CH2c & BL3 & 0,768 & 0,411 & 0,411 \\
BASAL & SHR & BL3 & 0,767 & 0,399 & 0,426
\end{tabular}




\begin{tabular}{|c|c|c|c|c|c|}
\hline BASAL & $\mathrm{CH} 2 \mathrm{c}$ & BL3 & 0,764 & 0,413 & 0,417 \\
\hline SAL & SHR & BL3 & 0,756 & 0,430 & 0,410 \\
\hline SAL & CH2a & BL3 & 0,742 & 0,437 & 0,397 \\
\hline SAL & SHR & BL4 & 0,737 & 0,431 & 0,445 \\
\hline SAL & $\mathrm{CH} 2 \mathrm{a}$ & BL4 & 0,731 & 0,449 & 0,451 \\
\hline BASAL & CH16 & BL3 & 0,727 & 0,457 & 0,401 \\
\hline SAL & CH16 & BL4 & 0,726 & 0,399 & 0,489 \\
\hline SAL & CH4 & BL3 & 0,716 & 0,456 & 0,430 \\
\hline BASAL & CH2a & BL4 & 0,716 & 0,417 & 0,480 \\
\hline BASAL & $\mathrm{CH} 2 \mathrm{c}$ & BL4 & 0,714 & 0,484 & 0,384 \\
\hline SAL & $\mathrm{CH} 2 \mathrm{c}$ & BL4 & 0,713 & 0,446 & 0,465 \\
\hline SAL & CH16 & BL3 & 0,704 & 0,413 & 0,416 \\
\hline BASAL & CH4 & BL4 & 0,698 & 0,438 & 0,476 \\
\hline SAL & SHR & BL2 & 0,677 & 0,383 & 0,545 \\
\hline SAL & CH4 & BL5 & 0,667 & 0,468 & 0,486 \\
\hline BASAL & SHR & BL4 & 0,665 & 0,492 & 0,480 \\
\hline SAL & $\mathrm{CH} 2 \mathrm{c}$ & BL5 & 0,648 & 0,475 & 0,505 \\
\hline SAL & CH2a & BL5 & 0,645 & 0,494 & 0,488 \\
\hline SAL & $\mathrm{CH} 2 \mathrm{a}$ & BL2 & 0,643 & 0,368 & 0,604 \\
\hline SAL & SHR & BL5 & 0,639 & 0,526 & 0,461 \\
\hline BASAL & SHR & BL5 & 0,614 & 0,512 & 0,501 \\
\hline BASAL & $\mathrm{CH} 2 \mathrm{c}$ & BL5 & 0,611 & 0,571 & 0,457 \\
\hline SAL & $\mathrm{CH} 2 \mathrm{c}$ & BL2 & 0,607 & 0,390 & 0,618 \\
\hline BASAL & CH16 & BL4 & 0,604 & 0,502 & 0,456 \\
\hline SAL & CH16 & BL2 & 0,603 & 0,361 & 0,648 \\
\hline SAL & CH16 & BL5 & 0,602 & 0,496 & 0,522 \\
\hline SAL & CH4 & BL2 & 0,593 & 0,422 & 0,593 \\
\hline BASAL & CH2a & BL5 & 0,583 & 0,511 & 0,547 \\
\hline BASAL & CH4 & BL5 & 0,563 & 0,545 & 0,506 \\
\hline BASAL & CH16 & BL5 & 0,553 & 0,503 & 0,511 \\
\hline BASAL & CH2a & BL1 & 0,549 & 0,650 & 0,354 \\
\hline BASAL & CH16 & BL1 & 0,534 & 0,685 & 0,368 \\
\hline BASAL & $\mathrm{CH} 2 \mathrm{a}$ & BL2 & 0,528 & 0,362 & 0,715 \\
\hline BASAL & CH4 & BL1 & 0,525 & 0,697 & 0,387 \\
\hline BASAL & $\mathrm{CH} 2 \mathrm{c}$ & BL2 & 0,521 & 0,380 & 0,710 \\
\hline SAL & SHR & BL1 & 0,510 & 0,539 & 0,155 \\
\hline BASAL & SHR & BL2 & 0,506 & 0,403 & 0,695 \\
\hline BASAL & CH4 & BL2 & 0,489 & 0,397 & 0,698 \\
\hline BASAL & SHR & BL1 & 0,485 & 0,721 & 0,389 \\
\hline BASAL & CH16 & BL2 & 0,484 & 0,243 & 0,556 \\
\hline BASAL & $\mathrm{CH} 2 \mathrm{c}$ & BL1 & 0,451 & 0,733 & 0,378 \\
\hline SAL & CH2a & BL1 & 0,444 & 0,631 & 0,266 \\
\hline SAL & CH4 & BL4 & 0,434 & 0,285 & 0,342 \\
\hline SAL & CH4 & BL1 & 0,429 & 0,616 & 0,508 \\
\hline
\end{tabular}




\begin{tabular}{llllll} 
SAL & CH2c & BL1 & 0,410 & 0,662 & 0,406 \\
SAL & CH16 & BL1 & 0,404 & 0,606 & 0,534 \\
\hline & & & & \\
& & 19,531 & 12,016 & 11,825 \\
de quadrados das cargas & & $39,1 \%$ & $24,0 \%$ & $23,6 \%$ \\
rção da variância & & $\mathbf{3 9 , 1 \%}$ & $\mathbf{6 3 , 1 \%}$ & $\mathbf{8 6 , 7 \%}$
\end{tabular}

Tabela 19. Análise Fatorial - dados de expressão gênica após categorização politômica.

\begin{tabular}{lllrrr}
\multicolumn{5}{c}{ Análise Fatorial - Animais congênicos (ordenação pelo fator 1) } \\
Exposção & Linhagem & Bloco & Fator 1 & Fator 2 & Fator 3 \\
\hline BASAL & CH2a & BL3 & 0,875 & 0,360 & 0,249 \\
BASAL & CH4 & BL3 & 0,872 & 0,357 & 0,265 \\
BASAL & SHR & BL3 & 0,869 & 0,355 & 0,272 \\
BASAL & CH2c & BL3 & 0,867 & 0,363 & 0,262 \\
SAL & SHR & BL3 & 0,860 & 0,373 & 0,276 \\
SAL & CH2c & BL3 & 0,858 & 0,375 & 0,273 \\
SAL & CH4 & BL3 & 0,853 & 0,388 & 0,276 \\
BASAL & CH2c & BL4 & 0,848 & 0,412 & 0,237 \\
SAL & CH2a & BL3 & 0,845 & 0,393 & 0,267 \\
SAL & CH16 & BL3 & 0,844 & 0,355 & 0,275 \\
SAL & SHR & BL4 & 0,842 & 0,392 & 0,296 \\
BASAL & CH16 & BL3 & 0,842 & 0,393 & 0,259 \\
SAL & CH2a & BL4 & 0,841 & 0,403 & 0,298 \\
BASAL & CH2a & BL4 & 0,841 & 0,382 & 0,307 \\
BASAL & CH4 & BL4 & 0,838 & 0,389 & 0,299 \\
SAL & CH16 & BL4 & 0,835 & 0,385 & 0,319 \\
SAL & CH2c & BL4 & 0,827 & 0,409 & 0,309 \\
BASAL & SHR & BL4 & 0,819 & 0,421 & 0,310 \\
SAL & SHR & BL2 & 0,798 & 0,384 & 0,363 \\
SAL & CH2a & BL2 & 0,787 & 0,376 & 0,390 \\
BASAL & CH16 & BL4 & 0,787 & 0,419 & 0,301 \\
SAL & CH2a & BL5 & 0,771 & 0,458 & 0,347 \\
SAL & SHR & BL5 & 0,770 & 0,473 & 0,335 \\
SAL & CH4 & BL5 & 0,765 & 0,443 & 0,354 \\
SAL & CH2c & BL2 & 0,762 & 0,389 & 0,399 \\
SAL & CH4 & BL2 & 0,760 & 0,402 & 0,380 \\
BASAL & CH2c & BL5 & 0,758 & 0,500 & 0,310 \\
SAL & CH2c & BL5 & 0,754 & 0,457 & 0,360 \\
SAL & CH16 & BL5 & 0,745 & 0,454 & 0,382 \\
BASAL & CH2a & BL5 & 0,739 & 0,468 & 0,386
\end{tabular}




\begin{tabular}{clllll} 
SAL & CH16 & BL2 & 0,735 & 0,358 & 0,433 \\
BASAL & SHR & BL5 & 0,728 & 0,472 & 0,359 \\
BASAL & CH4 & BL5 & 0,698 & 0,486 & 0,364 \\
BASAL & CH2a & BL1 & 0,696 & 0,576 & 0,242 \\
BASAL & CH2a & BL2 & 0,690 & 0,338 & 0,492 \\
BASAL & CH16 & BL5 & 0,686 & 0,446 & 0,373 \\
BASAL & CH16 & BL1 & 0,685 & 0,586 & 0,265 \\
BASAL & SHR & BL2 & 0,683 & 0,370 & 0,480 \\
BASAL & CH4 & BL1 & 0,681 & 0,588 & 0,260 \\
BASAL & SHR & BL1 & 0,677 & 0,595 & 0,269 \\
BASAL & CH2c & BL2 & 0,663 & 0,351 & 0,490 \\
BASAL & CH4 & BL2 & 0,658 & 0,344 & 0,502 \\
BASAL & CH2c & BL1 & 0,644 & 0,597 & 0,261 \\
SAL & SHR & BL1 & 0,595 & 0,483 & 0,104 \\
SAL & CH4 & BL1 & 0,586 & 0,523 & 0,380 \\
SAL & CH2a & BL1 & 0,580 & 0,561 & 0,185 \\
SAL & CH16 & BL1 & 0,573 & 0,510 & 0,403 \\
SAL & CH2c & BL1 & 0,551 & 0,558 & 0,299 \\
BASAL & CH16 & BL2 & 0,522 & 0,213 & 0,428 \\
SAL & CH4 & BL4 & 0,509 & 0,176 & 0,273 \\
\hline & & & & & \\
Soma de quadrados das cargas & & 28,347 & 9,423 & 5,571 \\
Proporção da variância & & $56,7 \%$ & $18,8 \%$ & $11,1 \%$ \\
Variância acumulada & & & $\mathbf{5 6 , 7 \%}$ & $\mathbf{7 5 , 5 \%}$ & $\mathbf{8 6 , 7 \%}$
\end{tabular}

A primeira conclusão dos resultados da $\mathrm{AF}$, tanto para a variável de expressão gênica quantitativa como categorizada (dicotômica e politômica) se refere à interpretação do primeiro fator, o qual pode ser rotulado como um "Fator Bloco", uma vez que a ordenação dos pesos atribuídos aos grupos dentro fator respeitam, notoriamente, a ocorrência dos blocos definidos no delineamento experimental. Neste sentido há uma ponderação gradativa (decrescente) quando observada individualmente a rotulação dos blocos 3, 4, 5, 2 e 1 .

Uma segunda conclusão da AF, sob os resultados apresentados nas Tabelas $18 \mathrm{e}$ 19, diretamente relacionada à TRI, se refere à interpretação de que a utilização dos modelos unidimensionais (um fator latente) para o conjunto de dados de animais congênicos estará contemplando, aproximadamente, 39,1\% (modelo dicotômico) e $56,7 \%$ (modelo politômico) de toda a variabilidade presente nos dados. Deste modo, principalmente para o modelo dicotômico, talvez, a alternativa unidimensional da TRI 
aplicada neste trabalho seja muito restritiva para representar a variabilidade total dos dados. 


\section{Referências}

[1] B. Alberts, A. Johnson, J. Lewis, M. Raff, K. Roberts, and P. Walter, Molecular biology of the cell, fourth ed., Garland Science, New York, 2002.

[2] D. B. Allison, X. Cui, G. P. Page, M. Sabripour, Microarray data analysis: from disarray to consolidation and consensus, Nat. Rev. Genet. (2006); 7:55-65. [PubMed]

[3] E. B. Andersen, Conditional inference in multiple choice questionnaires, British Journal of Mathematical and Statistical Psychology (1973), 26, 31-44.

[4] D. F. Andrade, R. Klein, Métodos estatísticos para avaliação educacional: Teoria de Resposta ao Item, Boletim da Associação Brasileira de Estatística (1999), 43, 21-28. [5] D. F. Andrade, H. R. Tavares, R. C. Valle, Teoria da Resposta ao Item: Conceitos e Aplicações, Caxambu: Associação Brasileira de Estatística, 2000.

[6] D. Andrich, A rating formulation for ordered response categories, Psychometrika (1978), 43, 561-573.

[7] C. L. N. Azevedo, Métodos de estimação na teoria de resposta ao item, Dissertação de Mestrado, Instituto de Matemática e Estatística, USP, 2003.

[8] D. Baird, P. Johnstone, T. Wilson, Normalization of microarray data using a spatial mixed model analysis which includes splines, Bioinformatics (2004), 20:3196-3205.

[9] F. B. Baker, Seock-Ho Kim, Item Response Theory - Parameter Estimation Techniques, second ed., Marcel Dekker, Inc, 2004.

[10] F. B. Baker, The Basics of Item Response Theory, ERIC Clearinghouse on Assessment and Evaluation, 2001.

[11] P. Baldi, A. D. Long, A Bayesian framework for the analysis of microarray expression data: regularized $t$-test and statistical inferences of gene changes, Bioinformatics (2001), 17(6):509-519.

[12] Y. Benjamini, Y. Hochberg, Controlling the false discovery rate - a practical and powerful approach to multiple testing, J. R. Stat. Soc. (1995), Ser. B 57, 289-300.

[13] Y. Benjamini, A. Krieger, D. Yekutieli, Two-staged linear step-up FDR controlling procedure, Technical Report, Department of Statistics and Operation Research, Tel- 
Aviv University, and Department of Statistics, Wharton School, University of Pennsylvania (2001).

[14] Y. Benjamini, E. Kenigsberg, A. Reiner, D. Yekutieli, FDR adjustments of Microarray Experiments (FDR-AME), Department of Statistics and O.R., Tel Aviv University (2005).

[15] A. Birnbaum, Some Latent Trait Models and Their Use in Inferring an Examinee's Ability, In F.M. Lord \& M.R. Novick, Statistical Theories of Mental Test Scores, Reading, MA:Addison-Wesley (1968).

[16] R. D. Bock, M. Lieberman, Fitting a response model for dichotomously scored items, Psychometrika (1970), 35, 179-197.

[17] R. D. Bock, Estimating item parameters and latent ability when responses are scored in two or more nominal categories, Psychometrika (1972), 37, 29-51.

[18] R. D. Bock, M. F. Zimowski, Multiple Group IRT - In Handbook of Modern Item Response Theory. W.J. van der Linder e R.K. Hambleton Eds. New York: SpringVerlag, 1997.

[19] B. M. Bolstad, R. A. Irizarry, M. Astrand, T.P. Speed, A comparison of normalization methods for high density oligonucleotide array data based on variance and bias. Bioinformatics (2003), 19(2):185-193.

[20] B. Bolstad, Low Level Analysis of High-density Oligonucleotide Array Data: Background, Normalization and Summarization, Ph.D. thesis, University of California, Berkeley, 2004.

[21] A. Brazma, P. Hingamp, J. Quackenbush, G. Sherlock, P. Spellman, C. Stoeckert, J. Aach, W. Ansorge, C. A. Ball, H. C. Causton, Minimum information about a microarray experiment (MIAME) - toward standards for microarray data, Nature Genetics (2001), 29: 365-371

[22] P. O. Brown, D. Botstein, Exploring the new world of genome with DNA microarrays, Nature Genetics, (1999), 21, 33-37.

[23] S. Calza, D. Valentini, Y. Pawitan, Normalization of oligonucleotide arrays based on the least-variant set of genes, BMC Bioinformatics (2008), 9(1):140.

[24] J. J. Chen, R. R. Delongchamp, Chen-An Tsai, Huey-miin Hsueh, F. Sistare, K. L. Thompson, V. G. Desai, J. C. Fuscoe, Analysis of variance components in gene expression data, Bioinformatics (2004), Vol. 20 no. 9, 1436-1446. 
[25] J. W. Chou, R. S. Paules, P. R. Bushel, Systematic variation normalization in microarray data to get gene expression comparison unbiased, Journal of Bioinformatics and Computational Biology (2005), 3(2):225-241.

[26] G. A. Churchill, Fundamentals of experimental design for cDNA microarrays, Nature Genetics (2002), 32(Suppl):490-495.

[27] G. A. Churchill, Using ANOVA to analyze microarray data, Biotechniques (2004), 37, 173-177.

[28] B. Coe, B. Antler, Spot your genes - an overview of the microarray, BioTeach. Disponível em http://www.bioteach.ubc.ca/MolecularBiology/microarray/. Acessado em 4/12/2009.

[29] X. Q. Cui, M. K. Kerr, G. A. Churchill, Transformations for cDNA microarray data, Stat. Appl. Genet. Mol. Biol. (2003), 2:article 4.

[30] X. Q. Cui, G. A. Churchill, Statistical tests for differential expression in cDNA microarray experiments, Genome Biol. (2003), 4:210.

[31] X. Q. Cui, J. T. Hwang, J. Qiu, N. J. Blades, G. A. Churchill, Improved statistical tests for differential gene expression by shrinking variance components estimates, Biostatistics (2005), 6, 59-75.

[32] A. R. Dabney, J. D. Storey, A new approach to intensity-dependent normalization of two-channel microarrays, Biostatistics (2007), 8: 128-139.

[33] S. Datta, S. Datta, Empirical Bayes screening of many p-values with applications to microarray studies. Bioinformatics (2005), 21, 1987-1994.

[34] J. H. Do, D. K. Choi, Normalization of microarray data: single-labeled and duallabeled arrays, Mol. Cells (2006), 22, 254-261.

[35] S. Draghici, Data Analysis Tools for DNA Microarrays, second ed., Chapman \& Hall /CRC Press: Boca Raton, Florida, 2003.

[36] S. Dudoit, Y. H. Yang, M. J. Callow, T. P. Speed, Statistical methods for identifying genes with differential expression in replicated cdna microarray experiments, Stat. Sin. (2002), 12(1):111-139. 
[37] S. Dudoit, J. P. Shaffer, J. C. Boldrick, Multiple hypothesis testing in microarray experiments, Stat. Sci. (2003), 18:71-103.

[38] S. Dudoit, M. J. van der Laan, Multiple Testing Procedures with Applications to Genomics, Springer, 2008.

[39] R. A. Fisher, Statistical Methods for Research Workers, Oliver and Boyd, Edinburg, 1925.

[40] C. Fraley, A. E. Raftery, How many clusters? Which clustering method? Answers via model-based cluster analysis, Computer J (1998), 41:578-588.

[41] H. Gulliksen, Theory of Mental Tests, New York: John Wiley and Sons, 1950.

[42] Y. Z. Guo, M. Li, M. Lu, Z. Wen, K. Wang, G. Li, J. Wu, Classifying G proteincoupled receptors and nuclear re-ceptors on the basis of protein power spectrum from fast Fourier transform, AMINO ACIDS (2006), 30, 397-402.

[43] J. R. de Haan, R. Wehrens, S. Bauerschmidt, E. Piek, R. C. van Schaik, L. M. C. Buydens, Interpretation of ANOVA models for microarray data using PCA, Bioinformatics (2007), 23:184-190.

[44] A. J. Hartemink, D. K. Gifford, T. S. Jaakkola, R. A. Young, Maximum Likelihood Estimation of Optimal Scaling Factors for Expression Array Normalization, SPIE BiOS: 4266, San Jose, California, 2001.

[45] A. A. Hill, E. L. Brown, M. Z. Whitley, G. Tucker-Kellogg, C. P. Hunter, D. K. Slonim, Evaluation of normalization procedures for oligonucleotide array data based on spiked cRNA controls, Genomebiology (2001), 2, 1-13.

[46] R. A. Irizarry, B. M. Bolstad, F. Collin, L. M. Cope, B. Hobbs, T. P. Speed, Summaries of Affymetrix GeneChip probe level data, Nucleic Acids (2003), Res. 31:e15. [47] T. E. Juenger, T. Wayne, S. Boles, V. V. Symonds, J. McKay, S. J. Coughlan, Natural genetic variation in whole-genome expression in Arabidopsis thaliana: The impact of physiological QTL introgression, Mol. Ecol. (2006), 15: 1351-1365.

[48] L. C. U. Junqueira, J. Carneiro, Biologia Celular e Molecular, oitava ed., Rio de Janeiro, Guanabara Koogan, 2005.

[49] M. K. Kerr, M. Martin, G. A. Churchill, Analysis of variance for gene expression microarray data, J. Comput. Biol. (2000), 7:819-837.

[50] M. K. Kerr, G. A. Churchill, Experimental design for gene expression microarrays. Biostatistics (2001), 2, 183-201. 
[51] M. K. Kerr, Design considerations for efficient and effective microarray studies. Biometrics (2003), 59, 822-828.

[52] B. Lewin, J. E. Krebs, E. S. Goldstein, S. T. Kilpatrick, Lewins's essential genes, second ed., Jones \& Bartlett Publishers, ISBN-10: 0763759155, 2009.

[53] C. Li, W. H. Wong, Model-based analysis of oligonucleotide arrays: model validation, design issues and standard error application, Genome Biology 2001, 2(8):reserach0032.

[54] H. Li, F. Hong, Cluster-Rasch Model for microarray gene expression data, Genome Biology 2001, 2(8):research0031.1-0031.13

[55] D. V. Lindley, Discussion of Professor Stein's paper, 'Confidence sets for the mean of a multivariate normal distribution', Journal of the Royal Statistical Society (1962), Series B 24, 265-296.

[56] D. J. Lockhart, E. A. Winzeler, Genomics, gene expression and DNA arrays, Nature (2000), 405:827-836.

[57] F. M. Lord, A theory of test scores, Psychometric Monograph $n^{\circ} .7,1952$.

[58] G. N. Masters, A Rasch model for partial credit scoring, Psychometrika (1982), $47,149-174$.

[59] M. McGee, Z. Chen, New spiked-in probe sets for the Affymetrix HG-U133a Latin square experiment, COBRA Preprint Series (2006), No. 5.

[60] G. J. McLachlan, K. E. Basford, Mixture Models: Inference and Applications to Clustering, New York: Marcel Dekker, 1988.

[61] R. J. Mislevy, Bayes modal estimation in item response models, Psychometrika (1986), 51, 177-195.

[62] D. C. Montgomery, Design and analysis of experiments, sixth ed., Wiley, New York, New York, USA, 2005.

[63] E. Muraki, A generalized partial credit model: Application of an EM algorithm, Applied Psychological Measurement (1992), 16, 159-176. 
[64] M. H. Kutner, J. Neter, C. J. Nachtsheim, W. Li, Applied Linear Statistical Models, McGraw Hill Higher Education; fifth International edition. ISBN-10: 0071122214, 2004.

[65] G. R. Norman, D. L. Streiner, Biostatistics: The bare essentials, third ed., Toronto, Canada, B. C. Decker, 2008.

[66] J. P. Novak, R. Sladek, T. J. Hudson, Characterization of variability in large-scale gene expression data: implications for study design, Genomics (2002), 79,104-113.

[67] A. Reiner, et al, Identifying differentially expressed genes using false discovery rate controlling procedures, Bioinformatics (2003), 19, 368-375.

[68] S. E. Embretson, S. P. Reise, Item response theory for psychologists, New Jersey: Lawrence Erlbaum, 2000.

[69] M. E. Ritchie, J. Silver, A. Oshlack, M. Holmes, D. Diyagama, A. Holloway, G. K. Smyth, A comparison of background correction methods for two-colour microarrays, Bioinformatics (2007), 23, 2700-2707.

[70] F. A. Samejima, Estimation of latent ability using a response pattern of graded scores, Psychometric Monograph, 17, 1969.

[71] S. V. Sanden, T. Burzykowski, The use of background signal in the transformation of cDNA-microarray measurements, Applied Bioinformatics (2006), 5(3):161-172.

[72] J. M. Satagopan, K. S. Panageas, A statistic perspective on gene expression data analysis, Statistics in Medicine (2003), 22:481-499.

[73] E. E. Schadt, C. Li, C. Su, W. H. Wong, Analyzing high-density oligonucleotide gene expression array data, J Cell Biochem (2000), 80(2):192-202.

[74] E. E. Schadt, C. Li, B. Ellis, W. H. Wong, Feature extraction and normalization algorithms for high-density oligonucleotide gene expression array data, J Cell Biochem Suppl (2001), Suppl 37:120-125.

[75] J. D. Silver, M. E. Ritchie, G. K. Smyth, Microarray background correction: maximum likelihood estimation for the normal-exponential convolution, Biostatistics (2009), 10:352-363.

[76] G. K. Smyth, T. P. Speed, Normalization of cDNA microarray data, Methods 31 (2003), 265-273. 
[77] G. K. Smyth, Y. H. Yang, T. P. Speed, Statistical issues in cdna microarray data analysis. In M. J. Brownstein, A. B. Khodursky, editors, Functional Genomics: Methods and Protocols - Methods in Molecular Biology, volume 224. Humana Press, Totowa, NJ, 2003.

[78] T. P. Speed, Hints \& Prejudices - Always Log Spot Intensities and Ratios, Technical Report, University of California, Bakerly, 2000. Disponível em www.stat.berkeley.edu/ terry/zarray/Html/log.html. Acessado em 04/12/2009.

[79] J. D. Storey, A direct approach to the false discovery rate, Journal of the Royal Statistical Society (2002), Series B, 64:479-498.

[80] V. G. Tusher, R. Tibshirani, G. Chu, Significance analysis of microarrays applied to the ionizing radiation response, Proc. Natl. Acad. Sci. USA (2001), 98, 5116-5121.

[81] H. M. Vianna, Testes em Educaçãoo, São Paulo, IBRASA, 1987.

[82] E. Vittinghoff, D. V. Glidden, S. C. Shiboski, C. E. McCulloch, Regression Methods in Biostatistics - Linear, Logistic, Survival, and Repeated Measures Models, Springer, New York, 2005.

[83] M. West, Bayesian factor regression models in the 'large p, small n' paradigm, J. M. Bernardo, M. J. Bayarri, J. O. Berger, A. P. Dawid, D. Heckerman, A. F. M. Smith, M. West, Bayesian Statistics 7 (2003). Oxford: Oxford University Press, pp. 723-732.

[84] P. H. Westfall, S. S. Young, Resampling-Based Multiple Testing, John Wiley \& Sons, New York, 1993.

[85] R. D. Wolfinger, G. Gibson, E. D. Wolfinger, L. Bennett, H. Hamadeh, P. Bushel, C. Afshari, R. S. Paules, Assessing gene significance from cDNA microarray expression data via mixed models, J. Comput. Biol. (2001), 8:625-637.

[86] Y. Woo, J. Affourtit, S. Daigle, A. Viale, K. Johnson, J. Naggert, G. A. Churchill, A comparison of cDNA, oligonucleotide, and Affymetrix GeneChip gene expression microarray platforms, J. Biomol Tech. (2004), 15(4), 276-284.

[87] H. Wu, M. K. Kerr, G. A. Churchill, MAANOVA: a software package for the analysis of spotted cDNA microarray experiments. In The Analysis of Gene Expression Data: Methods and Software. Springer, New York, 2008. 
[88] H. Wu, modified by H. Yang, with ideas from G. A. Churchill, K. Kerr, X. Cui, MAANOVA: Tools for analysing Micro Array experiments, R package version 1.4.1, 2008 .

[89] H. Xiong, D. Zhang, C. J. Martyniuk, V. L. Trudeau, X. Xia, Using Generalized Procrustes Analysis (GPA) for normalization of cDNA microarray data, BMC Bioinformatics (2008), 9:25.

[90] Y. H. Yang, M. J. Buckley, T. P. Speed, Analysis of cDNA microarray images, Brief. Bioinformatics (2001), 2, 341-349.

[91] Y. H. Yang, S. Dudoit, P. Luu, D. M. Lin, V. Peng, J. Ngai, T. P. Speed, Normalization for cDNA microarray data: a robust composite method addressing single and multiple slide systematic variation. Nucleic Acids Res (2002), 30(4):e15.

[92] Y. H. Yang, T. P. Speed, Design issues for cDNA microarray experiments, Nat. Rev. Genet. (2002), 3:579-583.

[93] D. Yekutieli, Y. Benjamini, Resampling-based false discovery rate controlling multiple test procedures for correlated test statistics, J. Stat. Plan Infer. (1999), 82, 171-196.

[94] W. Yin, T. Chen, S. X. Zhou, A. Chakraborty, Background correction for cDNA microarray images using the $T V+L^{1}$ model, Bioinformatics (2005), 21(10):2410-2416.

[95] A. Zaha, Biologia Molecular Básica, terceira ed., Porto Alegre, Mercado Aberto, 2003. 